PLANNING THE MILLENNIUM CITY: THE POLITICS OF PLACE-MAKING IN GURGAON, INDIA

\author{
A Dissertation \\ Presented to the Faculty of the Graduate School \\ of Cornell University \\ In Partial Fulfillment of the Requirements for the Degree of \\ Doctor of Philosophy \\ by \\ Shoshana Ruth Goldstein \\ August 2019
}


(C) 2019 Shoshana Ruth Goldstein 


\title{
PLANNING THE MILLENNIUM CITY: THE POLITICS OF PLACEMAKING IN GURGAON, INDIA
}

\author{
Shoshana Ruth Goldstein, Ph. D. \\ Cornell University 2019
}

Critics of Global South urban- and suburbanization have argued that Asian cities, driven by real estate development and the homogenizing effects of "global city" planning, lack a coherent sense of place or avenues for the art of placemaking. The dissertation unsettles these assumptions, exploring the nature of placemaking and community development for the purportedly unplanned, real estate driven city of Gurgaon or Gurugram, on the outskirts of Delhi, India, also known as the Millennium City. The dissertation follows Gurgaon's history and rise since India's economic liberalization in the 1990s. Despite its wealth and connections to global circuits of capital, the city has not produced a clear set of winners and losers in the battle for control of its central place-narrative or quality of life. Even Gurgaon's most affluent enclaves struggle with the provision of basic infrastructure and services, severe pollution, and fragmented governance, alongside extreme inequality and poor living conditions for migrant workers in adjacent urban villages. This dissertation frames Gurgaon as a starter city, built by private corporations, but also newcomers, including laborers from rural villages, affluent households returning home to India after years abroad, and the indigenous Haryanvi farmers of Gurgaon District, who find themselves in a new place, without having moved at all. The dissertation delves into the social construction of place in the Indian city, its loss and recuperation, and the ways in which practices of placemaking and recovery present alternative approaches to planning under the highly privatized "Gurgaon Model." The dissertation contributes to theoretical debates about how the decentralization of planning practice in India and the integration of housing, land use and governance frameworks can promote social coherence and community development, as 
well as how a sustained and grounded analysis of place and place attachment in cities of the Global South can better inform planning theory and practice in the years to come. 


\section{BIOGRAPHICAL SKETCH}

Shoshana Goldstein was born in New York City, and grew up in suburban New Jersey. She attended St John's College in Annapolis Maryland for a BA in Philosophy and the History of Math and Science in 2006. She went on to earn her MA in International Affairs, with a concentration in cities and urbanization from the New School in 2010. Before joining the Cornell's doctoral program in the Department of City and Regional Planning, she worked as a Consultant for UNICEF and the United Nations Department of Economic and Social Affairs (UNDESA), and as a Researcher at the India China Institute. While a PhD student at Cornell, she received funding for Hindi language study and research from two Foreign Language and Area Studies (FLAS) grants, including a Fieldwork Dissertation Grant, as well as a Critical Language Scholarship from the US Department of State. Her research was also supported by a generous grant from the Clarence S. Stein Institute for Urban and Landscape Studies. While conducting fieldwork in Delhi, she held scholarly affiliations with Jawaharlal Nehru University (JNU) and the Institute for Economic Growth and has since worked as a Visiting Lecturer and taught graduate and undergraduate seminars in Cornell's Department of City and Regional Planning. 


\section{ACKNOWLEDGMENTS}

I would like to thank first and foremost my Committee members, Neema Kudva, in Cornell's Department of City and Regional Planning (my Chair), Durba Ghosh in the Department of History, and Jeremy Foster in the Department of Architecture, for their support, integrity, patience, and guidance from the beginning of this ambitious project. Over the years, I have had discussions about my work with many faculty members across Cornell who helped shape my thinking about this project, including CRP's John Forester and Jeff Chusid, and faculty members in the Department of Government, including Michael Jones-Correa and Ron Herring. I am also deeply indebted to my Hindi teacher at Cornell, Sujata Singh, not only for her instruction, but for her continued advice with research tools and materials.

I could not have undertaken this project without the support of Cornell's Department of City and Regional Planning and the South Asia Program at Cornell, as well as the American Institute of Indian Studies, the Einaudi Centre, the FLAS Program at Cornell and the Clarence Stein Institute and their communities of scholarship.

I am deeply indebted to scholars, researchers and local organizers who offered invaluable advice and direction on the ground in Gurgaon and Delhi, including Vishal Narain, Mukta Naik at the Centre for Policy Research, Reshmi Theckethil, Veena Oldenburg, Latika Thurkal, Chetan Agarwal, Chetan Kapoor, Kailash Gusain, Swanzal Kak Kapoor, Poonam Prakash at the Delhi School of Planning and Architecture (SPA), and Sanjay Srivastava, my faculty advisor and affiliate at JNU and the Institute for Economic Growth, Delhi, as well as Srotriya Chowdury, my 
Research Assistant in Gurgaon, and Dominic Matthew, my Assistant at Cornell.

I am grateful for the friendship and humor of my hosts in Delhi and Gurgaon, including Ekta Kapur, Keerat Jassal, Mohit Strivastava, Shilpi Singh, Manish Sinha, and Malashri Lal, as well as Anurag Jetly, my photography teacher, who helped me see Gurgaon with fresh eyes and the loan of his camera equipment.

Throughout this process I have also returned to a community of students, Cornell alumni, and mentors who have provided invaluable feedback on my ideas and professional development, including Emily Goldman, Hayden Kantor, Scott Sorrell, Osama Siddiqui, Mushahid Hussain, Nidhi Subramanyam, Ashima Krishna-Jayant, Peter Wissoker, Sonia Ahmed, Melanie Sand, Sudeshna Mitra, Lesli Hoey, Andy Rumbach, Michael Cohen, Adriana Abdenur, and Taru Ruchi. 
TABLE OF CONTENTS

$\begin{array}{ll}\text { LIST OF ABBREVIATIONS } & 10\end{array}$

PREFACE 12

CHAPTER 1: THEORIZING THE MILLENNIUM CITY 19

$\begin{array}{ll}\text { I. Introduction: The Bad City } & 19\end{array}$

II. The Kind of Problem Gurgaon is 32

III. Central Concepts 36

IV. Organization of the Dissertation 62

CHAPTER 2: THE PLACE OF NARRATIVES IN GURGAON'S HISTORY 67

I. Introduction: The role of central place narratives 67

II. The Gurgaon Experiment 75

III. The Architect of Modern Haryana $\quad 79$

IV. Maruti, Son of the Wind God 81

V. Building the Millennium City 90

VI. Conclusion 101

CHAPTER 3: PLANNING THE MILLENNIUM CITY 104

I. Introduction: The Prodigal Planners 104

II. Common Critiques of Planning in India 113

III. Fear of Embeddedness 118

IV. A Community of Practice, not Place 122

V. Proprietary Knowledge and the Public Domain 129

VI. Action without Embeddedness 133

CHAPTER 4: Gated Gurgaon and the Suburban Imaginary 139

I. Introduction: Putting Down Roots in New Gurgaon 139

II. The Place that Was Promised: The Indian Middle-Class Suburban Imaginary 149

III. Place-Protection: Fear and Failure in Gated Colonies 151

IV. The Boundary Wall: Defending Nirvana 161

V. A Tale of Two RWAs 168

Part 2: DLF City's RWA 177

VI. Beyond the Gates: The Good Citizens 181

VII. The Good Citizens Part 2 
I. Introduction

II. Sikanderpur Village

III. A Village History Retold

IV. The Rent Crop

V. The Landlord's Daughter

VI. Conclusion

CHAPTER 6: MIGRATION AND URBAN CITIZENSHIP

I. Introduction: A Journey to the City and Back Again

II. Internal Migration and Urbanization in India

III. Local Discrimination and Tenant Suppression

IV. The Urban Village: Migration and Working Life

VI. Documentation and Discrimination

VII. The Cost-Benefit of Invisibility

VII. The Paradigm of Migrant Assistance

VIII. Conclusion

CHAPTER 7: CONCLUSION 263

APPENDIX A: METHODS 282

I. Archive

II. Structured and Semi-Structured Interviews 283

III. Participant Observation 287

IV. Survey 288

V. Mapping 289

APPENDIX B: INTERVIEW PROTOCOLS AND SAMPLE QUESTIONS 290

Questionnaire/Interview Protocol 290

Urban Village Household Survey Instrument/Questionnaire 294

APPENDIX C: DLF AND URBAN VILLAGE LOCATIONS 297

REFERENCES 298 


\section{LIST OF ABBREVIATIONS}

BJP - Bharatiya Janata Party

DDA - Delhi Development Authority

DC - District Commissioner

DDC - Deputy District Commissioner

DLF - Delhi Land and Finance Corporation

DTP - Department of Town and Country Planning

EC - Executive Committee

FAR - Floor to Area Ratio

FIR - First Information Report (reporting a crime)

HUDA - Haryana Urban Development Authority

IAS - Indian Administrative Service

LAC - Land Acquisition Collector

LS - Lok Sabha

MC - Municipal Counselor

MCG - Municipal Corporation of Gurgaon

MLA -Member of the Legislative Assembly

MP - Madhya Pradesh

MP- Member of Parliament

NCR - National Capital Region

NCT - National Capital Territory

NRI - Non-Resident Indian

OBC - Other Backward Class 
PAN - Permanent Account Number

PM - Prime Minister

PPP - Public Private Partnership

RTI - Right to Information Act

Rs - Rupees

RWA - Resident Welfare Association

SC - Scheduled Caste

ST - Scheduled Tribe

UC - Unauthorised Colony

UP - Uttar Pradesh

WB - West Bengal 


\section{PREFACE}

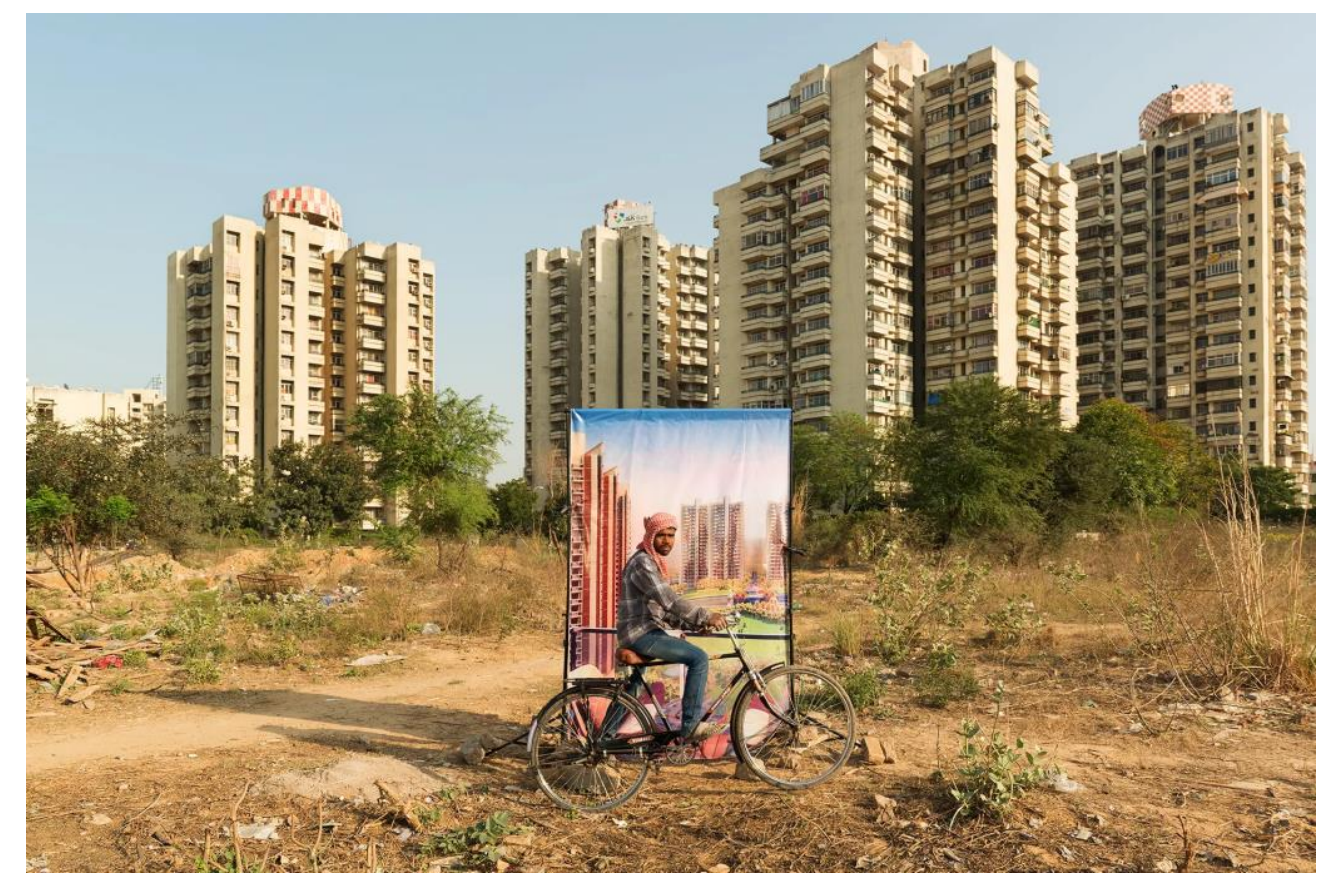

Figure 1: "GSD Drive \#2: Inspired by the Expanses of Central Park, New York and Hyde Park, London" Arthur Crestani, 2018

An exhibit called "Bad City Dream" made it to the 2018 Jury selection at the Paris Circulations Festival. ${ }^{1}$ The photographer, Arthur Crestani, posed Indian laborers in front of dismal-looking construction sites and apartment complexes around Delhi's satellite city, Gurgaon or Gurugram, notorious for its speculative real estate development and dismal-looking construction sites. In the photographs, a projection screen stands behind each subject and the site, blocking and juxtaposing their view with a computer rendered image of luxury housing. The photographs were composed to contrast wealth with "those who, although excluded from the chest-thumping

\footnotetext{
${ }^{1}$ (Mar 2018). Dream Home? India's Privatised City in Pictures. The Guardian. Retrieved from: https://www.theguardian.com/cities/gallery/2018/mar/15/bad-city-dreams-arthurcrestani-gurgaon-in-pictures
} 
discourse of prosperity, modernisation and development, made up the majority of Gurgaon's population."2

Since its meteoric rise in the 1990s, Gurgaon (now Gurugram) has often been portrayed as a stage, blank canvas, or "dream theater," in which nightmare and fantasy scenarios of urban living have played out. Gurgaon was once a collection of rural villages on the periphery of India's capital, considered culturally backward and agriculturally underproductive since the establishment of the new state of Haryana (cut out of the Punjab) in the 1960s. In a few decades (roughly 1990-2010), Gurgaon became a city of more than 2.5 million, spread over nearly 250 sq. miles. Gurgaon offered a success story in terms of real estate capital and economic development to some, but a cautionary tale on the dangers of allowing real estate to dictate urban planning in India to many more. The research in this dissertation, conducted from 2015-2016, explores the tensions between Gurgaon's dystopian and utopian urban imaginaries; between image and reality, wealth and poverty, in a city that people love to hate. As a planner, I was initially interested in understanding the so-called bad city's "wicked problems". ${ }^{3}$ In the process, I found myself working to deconstruct the bad city label altogether.

\footnotetext{
2 ibid

${ }^{3}$ Reference to Rittel and Weber's (1973) seminal piece on the epistemological challenges of defining and solving policy problems scientifically. They assert that planning problems are inherently "wicked problems": difficult to formulate, unending, solutions are normative as opposed to true or false, whether or not they've been solved is a subjective matter, they can't be simulated or tested in advance, they do not present an exhaustible number of solutions, each problem is unique, each problem is related to another problem, the way in which we define the problem also determines the solution, and planners have an ethical responsibility to the public in real time that scientists testing hypotheses do not. Rittel, H.W.J. \& Weber, M.M. (1973). Dilemmas in a General Theory of Planning. Policy Sciences, 4(2), 155-169.
} 
When I first visited Gurgaon, it looked every bit like Crestani’s photos. I collected calendars and brochures of real estate imagery, fantastical visions of condos, gated communities and parks. I visited Gurgaon's “Mall Mile” on Mehrauli Gurgaon (MG) Road. I stayed in a gated colony of semi-detached Victorian inspired townhouses, accessible from a four-lane road without traffic lights, plied by speeding trucks and donkey carts on their way to construction sites, over-stacked with rebar.

My homestay hosts had moved out to Sohna road on the edge of Gurgaon from Delhi for the quiet, but it was already becoming too chaotic and polluted for their taste. They found that city did not have much going for it beyond the corporate hubs. It lacked a "cultural umbilical cord," they said. If I wanted to experience real Indian culture, one of my hosts offered, I should visit Gurgaon's main attraction, an indoor theme park called the "Kingdom of Dreams" with its "Culture Gully," a food court and gift shop hall featuring the street foods and artisanal products of various Indian states. The main event of my evening there was a Bollywood style theater show. After three hours of lights, dance, music, and air conditioning, I exited the Kingdom of Dreams into a warm parking lot, with its mineral-tasting air, my ears and eyes adjusting to the muted sounds of drivers relaxing on the hoods of parked cars, smoking, chatting, waiting, listening in the dark to the radio program Gurgaon $\mathrm{Ki}$ Awaaz. ${ }^{4}$ On the way back to my homestay, my driver told me he was originally from Uttar Pradesh (UP). He was making good money now and would soon be able to afford his own car. Things were going well for his family. He would take me to meet

\footnotetext{
4 “Gurgaon's voice/sound" is a popular community radio program with over 1 million listeners, that provides Haryanvi programming, and favors local music and theater from Bihar, UP, Rajasthan, Punjab, Haryana over Bollywood and film music.
} 
them the next day, to have chai with his wife in a village not far from the gated community where I was staying. The pink, one-room flat they shared with their infant son was located on the second floor of a house that belonged to a local, Haryanvi family. The landlord and their friends, siblings, and relatives sat out on the veranda in plastic chairs during the visit, surveying the comings and goings, curious to see a foreign guest. After chai, we climbed to the roof of the house to look out over the village, a scene of trees and mustard fields to one side, and the cranes and construction sites in the distance. "See where we are," my host said.

I began to understand that writing an urban planning history of Gurgaon and its present challenges would involve triangulating complex relationships between the past and the future, wealth and poverty, old and new wealth, urban and rural, global and local, and the visible and invisible cords that connect people to themselves, to culture(s) that build in mud brick, concrete, rebar and glass, and to places both concrete or imagined. Understanding where I was would require not just exposing or expounding on the contradictions of place, but an attempt to find a way through those contradictions before I could speak constructively to planning theory and praxis.

My interest in contradictions emerged as an undergraduate philosophy major but grew stronger when my focus shifted to international development. My graduate studies emphasized the ethics of intervention in a postcolonial world and the retreat from the grand narratives of progress (in some quarters) in the latter decades of the 20th century. Cities of the Global South struggled with what Seyla Benhabib (1995) refers to as the challenges of "material reproduction" or "the economic means of subsistence and the maintenance of...material goods...buildings, roads, systems of 
communication, and cultural and artistic artefacts" (p. 237). Such empirical realities, she argues, are often distinguished from "symbolic reproduction" or the reproduction of those particularistic elements, practices, and values of community and culture in various contexts. ${ }^{5}$ In moments of extreme humanitarian crisis, this epistemic divide makes it easier for those who work in development to take hardline stances in favor of protecting women and children against cultural practices that harm their bodies and ability to thrive. The epistemological separation of material and symbolic life allows for the prioritization of well-being to direct a just course of action and an iterative practice of "doing development."

As a student of Global South urbanism, I encountered compelling scholarship that recognized, alongside the urgency of human material need, the vitality, empowerment, human capital, and resourcefulness of slum-dwellers and the urban poor. At the same time, I read less generous critiques of the Global South bourgeoise, enacting visions of the public sphere through the escapism and exclusion of walls,

\footnotetext{
${ }^{5}$ A postmodern, culturally relativistic world made it difficult, if not impossible to point out, as Bernard Williams called it "real confrontations." Benhabib observes that "real confrontations" are possible within a society when material and symbolic reproduction conflict. These moments of conflict can lead to transformation, where the norms of a society are challenged by observers/participants within, and this self-generated transformation can help guide us towards a more universal notion of justice. Benhabib, S. (1995). Cultural Complexity, Moral interdependence and the Global Dialogical Community. in eds. Nussbaum, M., \& Glover, J. Women, culture, and development: a study of human capabilities. Oxford, England: Oxford University.

6 In articulating Martha Nussbaum's plea for a cross-cultural concept of justice in an age of global connectedness, dependence, and emergency, Benhabib distinguished between material vs. symbolic reproduction. Benhabib identities several elements of symbolic reproduction: it requires its members to participate in a common language and set of expectations, to reproduce this culture and to coordinate this social reproduction as members of that group. These groups are not hermetically sealed, however, and as they occupy or cohabitate with other groups, must negotiate their survival, adapt, transform or perish.
} 
gated communities and suburban enclaves. Yet even the urban poor, at times, were enthralled by this vision, as portrayed in Crestani's photos. In some narratives, they were victims, empowered subjects or even co-conspirators in a bourgeois aesthetic governmentality. I came to the study and selection of Gurgaon as a research site because it highlighted these contradictions of success and failure in the Global South, which were most readily be explained by the ills of late capitalist accumulation and neoliberal city-making. The city's planning crises were not just those of the slum or the urban village, but also of the gated enclave. The symbolic was not just the working out of middle-class identities, or the peasantry grappling with urbanity and globalization, but how identity and territory were connected, and co-produced, thus contributing to conflicts between spatialized class groups, including the new middleclasses, rural migrants, and ancestral farming communities at the rural-urban interface. Gurgaon did not lack for cultural umbilical cords, but rather offered competing visions of what constituted "culture" in the first place, and how such visions ultimately produce the city.

I set out to study the planning of Gurgaon through the lens of place and placemaking because that was where the conceptual divide between material and symbolic reproduction fell apart for me, and where I saw the strongest possibilities for understanding and resolving those epistemological contradictions of development and urban planning in the Global South. In theories of place, including place attachment, I saw the explanation for why both the symbolic and material of everyday life could not be cleanly divided. In the scholarship on middle-class environmentalism in India for example, was the coming together of, on the one hand, problems of the built 
environment, of the material reproduction of the street as a functioning space, and on the other, the symbolic reproduction of the middle-class seeking emplacement in the public sphere, in turn, confronted with a shared reality and India's urban poverty. These territorial battles were never just about planning and making things work or look better, nor were they entirely about class conflict.

As a dissertation on the planning of a city with a reputation for no urban planners, this research ultimately explores the ways in which seemingly disparate placemakers work through their sense of place and thereby resolve tensions in the material and symbolic realms of everyday life. In this context, Planning becomes not just a formal practice or profession, but exists as an imaginary, that serves many needs for those who still hope for external recognition and assistance in maintaining, protecting and investing in places of meaning and value and the city to come. Planning becomes integral to the process of placemaking, a source of hope and technocratic model of self-determination, a way of reclaiming one's identity and a sense of belonging in an era of ecological uncertainty and rapidly changing urban environments. 


\section{CHAPTER 1: THEORIZING THE MILLENNIUM CITY}

\section{Introduction: The Bad City}

Gurgaon goes by many names. It was formally changed to Gurugram by Haryana's Chief Minister in 2016. ${ }^{7}$ Its commercial nickname, "the Millennium City", once evoked an image of a tabula rasa for a futuristic, well-functioning metropolis; "rising India's" city of the new millennium. Over a few decades of real estate development, Gurgaon sprawled outward from southwest Delhi into rural Haryana, absorbing the farmland and villages of Gurgaon District's arid, alluvial plains. Without a Municipal Corporation until 2008, Gurgaon developed in a void of citylevel urban planning. The overseers of its development operated from Haryana's capital to the north in Chandigarh. Meanwhile, the economic growth generated by Gurgaon's urbanization put Haryana among the wealthiest states in India (GDP per capita) by the 2000s and earned the city a reputation as one of the most prosperous (if unequal) in India. ${ }^{8}$

Twenty years on, the millennium city narrative triggers eye rolls for those who know it well. Regularly headlining with stories such as "Gurgaon, how not to build a

\footnotetext{
${ }^{7}$ Gurugram is considered the original variation of Gurgaon, although they have the same meaning in modern Hindi. Literal translation - Gur/Guru: teacher, Gram, Gaon: village. In reference to a character, Guru Dronacharya, at the center of the Sanskrit Mahabharata epic (89 th centuries BCE).

${ }^{8}$ As of 2013, credit ratings had put Gurgaon's wealth above Mumbai in terms of ownership of consumer durables. The findings also observed a wider wealth gap in Gurgaon than in Mumbai. Bhowmick, S. (Dec 28, 2013). Gurgaon most prosperous city in India. The Economic Times. Retrieved from: https://economictimes.indiatimes.com/gurgaon-mostprosperous-city-in-india/articleshow/28030074.cms
} 
city" or "Gurgaon will drown in its own filth,", the place has been so harshly criticized in the media that the Hindustan Times recently launched an "I Love Gurgaon" column to counter the bad press. ${ }^{10}$ Residents bring up the traffic congestion (another nickname is Gurujam), fragmented or non-functioning public services and infrastructure, some of the worst air pollution in the country, a lack of public space, and so on. Any one of these problems would raise alarms for outsiders as well as those who live and work in the city. They constitute what observers of and participants in Gurgaon's planning authorities might consider planning failure. Taken together, they force one to ask if there is any planning in Gurgaon at all. But this is usually posed as a rhetorical question, with a deeper ontological provocation. Most residents are aware that Gurgaon was the result of some kind of planning. Many of the city's harshest critics understand this history. They also happen to be the strongest supporters of Gurgaon's possibilities. They identify the city's challenges, planning failure and the inconveniences of the unlivable or bad city, as the result of conscious decision making, and the probable outcome of policies that supported Gurgaon's growth model and central place narrative among a set of local and elite actors. But even allowing that Gurgaon is the result of planning, one can still get trapped in tautologies: the bad city emerges from bad planning. The attempts to grapple with the rise of the bad city is nothing new. Variations of the trope have existed since human beings began to form dense settlements. At times, the vilification refers only to a neighborhood or portion of

\footnotetext{
${ }^{9}$ Anand, D. (Apr 2012). Gurgaon will drown in its own filth. Hindustan Times. retrieved from: https://www.hindustantimes.com/delhi-news/gurgaon-will-drown-in-own-filth/storymEOaC9KZaGhW8AmmpdiHsM.html

${ }^{10}$ Oldenburg, V. (2018). Gurgaon: From Mythic Village to Millennium City. Harper Collins India.
} 
the city, i.e. the slum, or the colonial "black town". In the past few centuries, cities on the rise, in population and wealth, invariably spark a backlash, (London, Paris, Chicago), in which attempts to grapple with the confluence of people, goods, and economic power generates a nostalgia, or in some cases, utopianist projects to counter the city's metastatic growth.

What is common to these places is that they evolve out of politically possible decision-making, compromise, conflict and the clash of ideologies, interests, and imaginaries on the road to the hoped for good city. ${ }^{11}$ With the circulation of ideas and capital after India's economic liberalization, Gurgaon encapsulated, in its mythic origin story, early empire, colonial and recent histories, a battleground for ideas about the good city, suburbia, the role of planning in the public domain, as well as placemaking in India. This battle carries on even as the lines between local caste groups and what Oldenburg (2018) refers to as the new castes of "politicians, bureaucrats and builders" have become increasingly blurred. For the most optimistic residents, the city's trajectory can be course corrected. An idea of planning still holds the promise of the good city.

In 2008, the same year Gurgaon's million plus population was awarded a municipal corporation, the world passed the $50 \%$ urban mark. Scholars and organizations tasked with addressing global poverty and urbanization began to tell and

\footnotetext{
${ }^{11}$ Roy (2009) explains planning failure as connected to informality and insurgence. Informality in this sense is not a contained sector of the economy, but a mode that pervades both formal and informal institutions and practices, ultimately favoring elites, but also leading to push back from below. The back and forth within this immense plurality, this struggle itself, paralyzes the possibility for swift or unified planning or intervention in Indian cities. Roy, A. (2009). Why India Cannot Plan Its Cities: Informality, Insurgence, and the Idiom of Urbanization. Planning Theory, 8(1), 76-87.
} 
repeat a doomsday narrative about the proliferation of slums and the "bottom billion" (Davis, 2006). Most of the world's future urbanization would occur in cities of the Global South, they warned, in places with few checks on urban migration, or the resources to provide housing, basic services or employment. The focus shifted to discussions of urban informality, primarily in terms of labor and housing, along with patterns that seemed to defy the historical trends in the Global North, such as urbanization without industrialization. Theorists proposed frameworks for reading cities of the Global South, i.e. Sassen's (1991) “Global Cities” or Robinson's (2006) "Ordinary Cities". The latter was an important critique, in some ways, of the unhelpful dichotomy between the good city (Global North) and the bad city (Global South). ${ }^{12}$ Robinson (2006) argued for a more diverse way of understanding modernity in globalizing Southern cities. ${ }^{13}$ Nonetheless, the Global City, that Sassen (1991) observed, seemed to retain its aspirational shine as a policy or planning project, and influenced the boosters, developers, planners and residents of cities across the Global South. One could frame Gurgaon as an ordinary city with global city aspirations. For the purposes of this research, I recognize the salient features that distinguish Gurgaonian urbanism as a phenomenon of post-liberalization Indian urbanism, and the policies and practices that came into favor in the 1990s in many parts of the Global South. The "Gurgaon model” observes several important characteristics:

\footnotetext{
12 Sassen, S. (1991). The global city: New York, London, Tokyo. Princeton, N.J.: Princeton University Press.

${ }^{13}$ Robinson, J. (2006). Ordinary cities: between modernity and development. London: Routledge.
} 
1. With the de-industrialization of cities or the decline in production and manufacturing as the primary route of capital accumulation, urbanization was driven largely by the service economy and the conversion of rural land for acquisition and redevelopment as residential and commercial property. Real estate investment, the "secondary circuit of capital accumulation" is what Shatkin (2017) refers to in his discussion of this broader trend, or Asia's "real estate turn". ${ }^{14}$

2. This process accelerated after the opening of insular or state-run economies to globalization and foreign direct investment. This was sometimes promoted by policy prescription packages, including the deregulation of land markets for the private sector in the recovery phase of the financial crises of the late 1970s1990 s, i.e. "the neoliberal turn" (Harvey, 2005). ${ }^{15}$

3. The real estate entrepreneurialism, that typifies Gurgaon's case, is also highly speculative, in a Global South context where there may be weaker checks on financial transactions and business practices and large black-market economies. The weak checks on these transactions speak to the eagerness of local governments and business communities to create new markets that will attract investment from international firms. In some cases, international firms have come courting these relationships, or learned belatedly that there are often

${ }^{14}$ Shatkin, G. (2017). Cities for profit: the real estate turn in Asia's urban politics. Ithaca: Cornell University Press.

${ }^{15}$ Harvey, D. (2005). A brief history of neoliberalism. Oxford: Oxford University Press. 
stark differences between predicted growth or prosperity, and the material reality or quality of services and infrastructure on the ground (Searle, 2016). ${ }^{16}$

4. In many cases, where the capacity of central governments to govern megaproject undertakings is weak, this type of gold rush urbanism produces a highly fragmented or splintered urbanism, with limited trunk infrastructure, and will take an enclaved built form, i.e. discrete gated communities. This is not unique to the Global South (Graham \& Marvin, 2001). ${ }^{17}$

5. In contrast to processes of suburbanization in the Global North, in which the middle-classes left the inner cities (and the urban poor) for suburbia, in India and many parts of the Global South, the low cost of labor and cultural norms of servitude ensure that domestic workers accompany the wealthy into their suburban imaginaries and remain in close proximity. These migrant laborers, typically live adjacent to or in the vicinity of their employment, so that the juxtaposition of prosperity and inequality is heightened as the slum and the suburban enclave or gated community are co-produced, entangled, socioeconomic and cultural worlds (Srivastava, 2015). ${ }^{18}$

6. While some of this urbanization arises from natural increase, most of it comes from the rezoning and incorporation of rural villages into urban areas and massive waves of internal migration that are often underreported or captured

\footnotetext{
${ }^{16}$ Searle, L. G. (2016). Landscapes of accumulation: real estate and the neoliberal imagination in contemporary India. Chicago: The University of Chicago Press.

${ }^{17}$ Graham, S. and Marvin, S. (2001). Splintering urbanism: networked infrastructures, technological mobilities and the urban condition. London: Routledge.

${ }^{18}$ Srivastava, S. (2015). Entangled urbanism: slum, gated community, and shopping mall in Delhi and Gurgaon. (First edition.). New Delhi, India: Oxford University Press.
} 
by official urban population figures (UN-Habitat, 2016). ${ }^{19}$ Even within the category of "internal migrant", there is a tremendous diversity of experience in terms of the type and composition of migrant households, migration strategy, opportunities for advancement, and political inclusion.

7. Because of the above conditions, and despite the wealth produced by these cities or poured into them, their speculative or splintered urbanisms carry the ongoing challenges of third world urbanism--weak or corrupt state capacity with limited revenues, conditions of scarcity and extreme poverty, colonial legacies, and social complexity that do not map neatly onto Global North conceptions of citizenship or urban living (Watson, 2009).

The research here theorizes Gurgaon's brand of urbanism as the archetypical "bad city" of the new millennium (the suburbs and the slums of the Global South), observing the above conditions, but focusing on how the city was/is discursively, materially and symbolically constructed as a place or places over time. My analysis responds, in many ways, to a call to action, by Watson (2009) and others: that in this current urban century, planners are facing not only tremendous challenges, but possible irrelevance in the Global South, and that we need planning theory that is grounded in these experiences, or a "view from the South" (Watson, 2009; Yiftachel, 1998) ${ }^{20}$ Dichotomies such as state/society or legal/illegal do not fully capture the

\footnotetext{
${ }^{19}$ United Nations Human Settlements Programme (UN-Habitat) (2016). Urbanization and Development: Emerging Futures.

${ }^{20}$ Using a Foucauldian analysis, Watson (2009) speaks of a "clash of rationalities" between the techno-managerial and marketized systems of government administration and informality of the city. Of course, planning systems are typically inherited from colonial planning authorities, sometimes for ideological reasons, as stated earlier. Over time, these systems may not change much. The role of planning agencies in these contexts is predominantly land
} 
realities of Southern cities. Informality is the dominant idiom (Roy, 2009). The participatory planning approaches developed in the Global North to deal with diverse communities $^{21}$, Watson (2009) argues, tend to assume conditions that do not always pertain to these contexts, i.e. that civil society is definable, relatively organized, homogeneous or consensus-seeking. ${ }^{22}$ Discourse around cities that emphasizes the binary of privileged vs. underprivileged, or wealth vs. poverty, also fail to capture the social complexity of India's place-based communities. These involve myriad caste, religious, linguistic and class relations constantly in flux (Rao, 2012). ${ }^{23}$ But the nuanced politics of identity formation, negotiation and change occurs in a context of extremes: where multiple publics appear in opposition, while local governments struggle to provide water and sanitation services, and large swaths of the population live at or below poverty, often in settlements without secure tenure and few legal rights as local citizens, let alone a voice in planning.

Over the latter portion of the 20th century, pro-growth strategies and the arguments of supply side economics gained a foothold in India's planning and urban development: poverty could be combatted or lessened by the trickle down of wealth

management.

${ }^{21}$ Nussbaum, M. C. (2011). Creating capabilities. Cambridge, MA: Harvard University Press.; Nussbaum, M. C. and Amartya, S. (1993). The quality of life. Oxford, UK: Clarendon.

22 The crisis of planning in the West, in the 1960s onward, involved the assumption that cultural minorities would eventually "assimilate". This term has gone out of favor and given way in the 1990s to the acceptance (in the planning literature at least) of ongoing multiculturalism. From this, ideas emerged about the ways in which planners could engage with cultural difference (Sandercock, 2004). But the diffusion of these revelations, or the communicative turn, didn't necessarily come to change the way that planning institutions operate in many parts of the global North or South. This may not necessarily reflect outdated training, so much as a deliberate choice (Watson, 2009).

${ }^{23}$ Rao, N. (2012). House but no Garden: Apartment Living in Bombay's Suburbs, 18981964.Minneapolis: University of Minnesota Press. 
from the middle and upper classes to the urban poor (Harvey, 2005, p. 64). The broader critique of places like Gurgaon is that this urban economy, as a product of its own social context, supported by state government, has failed to offer equity, functionality, and coherence or a clear sense of place for either the wealthy or the most vulnerable. The results are not just spatially uneven in terms of accumulation, they present a hybridization of neoliberal urban sprawl intermingled with Davis's (2006) "planet of slums": first and third world urbanism combined. For its critics, this brand of city-making offers the worst of both worlds.

In line with Watson (2009), I argue that planning in such a context operates at one level, driven by its own rationality, that either ignores or fails to address the lived reality of survival, social and cultural difference, economic and environmental precarity. Theorizing Gurgaon forces one to engage with how these worlds of wealth and poverty are not just deeply imbricated, but co-produced. As such, addressing one set of challenges, the problems of the gated community or the slum, must engage with or inadvertently address those of the other. Problems of separation occur in the anatomy of the city to be sure: the ways in which city wards and land use designations divide or "splinter" adjacent enclaves into competitors for water and power rather than integrate them into common pools, in the breakdown and fight over who controls, fixes, and maintains, pipes, roads, trash, open spaces and margins of the city that connect and serve discrete urban spaces. These infrastructural boundaries are materially, but also discursively, administratively and politically constructed before developers ever break ground. Their continued enforcement and failures influence the social construction of and segregation of place in important ways. 
Therefore, in answering the call to theorize, my work undertakes a grounded and contextual analysis, that engages with development and postcolonial literatures, but brings in the framework of place, placemaking and place attachment in reading Indian urbanism. In doing so, I also respond to a gap that Friedmann (2010) observed: planners of the Global South often lack an approach or imperative to think about placemaking, partially because of the above-mentioned neoliberal crisis of planning and city-making and historical obstacles to institutional change.

While I agree with this, I also seek to challenge how planners might define place as, for example, the small cherished residential spaces of dwelling, that are pedestrian friendly, that are and have, if not boundaries, then centers and interiorities of encounter. I draw inspiration from Massey's (1997) challenge and conceptualization of a "global sense of place" to question the efficacy of boundaries and the local scale in providing a full sense of place for city-dwellers, whose global awareness affects local practices and expectations in terms of urban living. ${ }^{24}$ This is where I bring the individual histories, cultural context, living conditions and perspectives of development and post-colonial thought to bear on grappling with place-based relationships in India, and planning's role in shaping them.

I begin with how the city has been problematized and consider what it would it mean to radically accept, without romanticizing, Gurgaon, or the bad city more broadly, as a place worth caring about. What would that shift allow one to see? In doing so, I realize that one can't simply focus on one "view" from the South. Rather, it

\footnotetext{
${ }^{24}$ Massey, D. (1997). A Global Sense of Place. in Barnes, T., \& Gregory, D. eds. Reading Human Geography. London: Arnold.
} 
becomes epistemologically and ethically necessary to triangulate multiple "views from the South" in order to capture a fuller sense of how places are created and experienced.

Grasping these different views and the common practices and relationships that constitute placemaking, attachment, as well as the limits on how they can be applied, requires a conceptual lexicon for the social construction of place. Of course, there are many ways of understanding cities as socially constructed; the extension of societal and individual webs of meaning and value. Lefebvre (1991) imagines the "spatial practice of a society secretes that society's space" using the image of a seashell, a biological structure built from the protein excretions of the organism it contains. ${ }^{25} \mathrm{No}$ place is completely exogenous to the people and the social practices that create and are reflexively shaped by it.

Place and space are innocuous words packed with meaning. As Cresswell (2004) observes, the word place has a kind of commonsense intuitive definition in everyday speech, yet as a concept continues to perplex and provide a rich field of inquiry for geographers and social scientists, as well as linguists. ${ }^{26}$ The ways in which individuals and communities both construct and attach to place, how it fits into their understanding of themselves, is critical to addressing issues of social justice, equity, and conflict in complex and segregated (administratively, economically, culturally) social environments. In the so-called bad city, the act of naming the systemic problems

\footnotetext{
${ }^{25}$ Lefebvre, H. (1991). The Production of Space. Oxford, OX, UK: Blackwell.

${ }^{26}$ Basso, K.H. (1996). Wisdom sits in places: Notes on a Western Apache landscape. Santa Fe, New Mexico: School of American Research Press.
} 
that often manifest and overlap with the cosmetics of the city, i.e. urban blight, social disorder and so on, tend to create or reinforce antinomies between different social classes, racial and ethnic groups, or political agendas. It is necessary to begin first with understanding why communities care about places, more intriguingly why they seem to love places they hate, and what needs those places serve or fail to.

Environmental psychologists, sociologists, and anthropologists have asserted for decades that place plays a critical role in mental health, identity formation and cognitive coherence for individuals and communities, yet often, these messages do not seem to inform the way planners think about cities, land use, or placemaking. To suggest that the affective needs of the individual for a sense of belonging, security, and stability through a connection to their environment, or that the emotional effect of a severed attachment might constitute a public health concern, still comes across as somewhat trivial or perhaps the unfortunate side effect of larger projects of urban renewal or redevelopment. Under the logics of eminent domain, one population's displacement, and any pain it might cause, is recast as a necessary sacrifice for the public good. There are ways in which the value of place is acknowledged. For example, compensation to slum-dwellers facing eviction acknowledges the economic devastation of a relocation. This approach can also be poorly executed, however, and fail to account for the basic economy of slum-dwelling, that relies on proximity to places of employment. A relocation could mean a loss of income or a longer commute at a greater cost. Social relationships that support a household in place, that supplement income, including horizontal networks with other slum-dwellers, or even vertical patronage relationships with landlords and employers nearby, may also be 
lost. For the ancestral inhabitants of a landscape, simply transplanting the entire community to a new location may also miss out on the supportive elements of place that are non-transportable or replicable. More often than not, the place-based work that attempts to consider these nuances is treated as an alternative or radical framework, where its potentialities for social and environmental justice become aestheticized; aestheticized in the sense that they carry the banner of intention and appear as gestures towards distributive justice, principles of equality by telling stories or making marginality visible, filling in the gaps to raise the standard of living by some measure. From the neoliberal planning perspective, addressing the needs of the urban poor for belonging in situ, is a stopgap until the benefits of economic development trickle down. When feeding and fostering the market becomes the substantive route to poverty alleviation, the project of listening to or understanding place-based needs begins to look like surface work. Placemaking has also been aestheticized and commodified as a luxury feature in urban design, and more cynically, as a way of adding value to real estate development.

This dissertation argues that it is essential to look at issues of place and place attachment in concert with structural questions of livability and economic prosperity in cities of the Global South. As a rising middle-class in India seeks new models for urban living, a market has emerged, not only in response to the demand (aware of specific tastes and preferences), but also to shape and inform it. As real estate development has become a proxy, not just in building, but also communicative planning and governance, the gulf that existed between public planning in India, and 
its urban publics risks widening and foreclosing other possibilities or paradigms for inclusive planning and the search for common ground among diverse communities.

\section{The Kind of Problem Gurgaon is}

Over the past few years, a literature has emerged problematizing the city of Gurgaon. Scholarship on the challenges of urbanization in the Global South may follow specific events, systems, structures or problems embedded in or produced through the urban context, and then demonstrate the ways in which a place becomes a valid or exceptional case in which to study the general. In the Gurgaon literature, the city tends to be presented as the problem statement. What kind of a problem is Gurgaon?

The most apparent analytical orientation is to read Gurgaon as the urban incarnation of neoliberalism. India's debt problems in the late 1980s prompted a change in management styles and the restructuring and opening of its economy. ${ }^{27}$ Gurgaon would urbanize over the decades and then crises preceding India's economic liberalization and participated so directly in the conversations and policy of the times (late 1970s to present day), that the "Gurgaon Model" was not just an example, but among the first instances of what Harvey (1989) describes as a shift from a managerial to an entrepreneurial style of urban governance in India. However, the effects of

\footnotetext{
27 The first step in Harvey's (2004) framework of accumulation by dispossession is the concentration of wealth in the hands of a few through interconnected processes of financialization, privatization, and state redistribution, with governments facilitating the bureaucratic side of this. These asset transfers aren't unique to late capitalist democracy, however. For example, the rights to groundwater underneath property in Haryana, which accumulate in the possession of large land holders, including corporations, are based on colonial era laws still in place.
} 
neoliberal policies follow highly contextual paths of "creative destruction" (Brenner \& Theodore et al, 2011). Gurgaon's planners, as actors within institutions framed by colonial government and administration, namely the Indian Administrative Service (IAS), used colonial laws, and the descendants of those laws, to support and facilitate its land-use conversions, beginning in the $1960 \mathrm{~s} .{ }^{28}$ In fact, the laws that real estate lobbyists fought to repeal in the 1980s-90s were often Nehruvian era laws, such as the land ceiling restrictions of the 1970s. The deals that were made between Haryana and real estate developers often came about through existing and long-standing networks of elites and politicians who played multiple overlapping roles as both political actors and entrepreneurs.

Gurgaon urbanized in a period when the Nehruvian project of state-sponsored infrastructure and mega-projects was falling out of favor. Haryana conceived an urban development model that gave licenses to real estate firms on the condition of fees and the provision of basic services and infrastructure. This process promoted the privatization and commodification of what were once public assets, including networked infrastructure. ${ }^{29}$

Gurgaon's urbanization originated with a land-grab boosted by a coalition or cabal of government and private actors. As real estate became the most profitable market for investment capital, the project of constructing or commodifying place became essential to economic development. ${ }^{30}$ This is not to suggest that Gurgaon fits

\footnotetext{
${ }^{28}$ Referring to the Maruti factory deal with Sanjay Gandhi in the 1960s.

${ }^{29}$ Harvey, D. (2004). The 'new' imperialism: accumulation by dispossession. Socialist Register, 40, 63-87.

${ }^{30}$ While Polanyi's earlier work is not central to the arguments here, he identified problems with the commodification of land (a "fictitious commodity") arguing that land is never a
} 
the growth machine model exactly. ${ }^{31}$ But it is important to recognize that Gurgaon's real estate market was also socially constructed, and therefore contingent on the interests and desires of specific actors. As I will discuss in Chapter 2, this development was fueled by a concerted push among real estate developers to change land use laws, finance construction, attract investment and multinational corporate headquarters and create a residential market for urban professionals. The opportunities for low risk, high-profit investments led to a fragmented urban network of enclaves, where only discrete developments remained legally possible or profitable. This is not unique to Gurgaon, but part of an observable trend, where local fears of crime, visible poverty, and the desire for exclusivity also promote the enclave model of premium access to certain users, separated from primary infrastructure networks (Graham \& Marvin, 2001). This process leads to a negative feedback loop: increased fragmentation of markets and consumers and the perpetuation of car dependence. ${ }^{32}$ This "splintered urbanism" further normalizes segregated space. It also materializes as Special Economic Zones (SEZ) and commercial hubs that function as cities within cities, even more cut off from their surroundings. The dream of escaping the context of a fractured city or inadequate networks is never fully realized, however. Wealth does not buy consistency or coherence or permit social escapism. The premium access

product in the purest sense, but always deeply embedded in social relations. Polanyi, K. (1944). The Great Transformation. Farrar \& Rinehart.

${ }^{31}$ Heller, P., Mukhopadhyay, P. and Walton, M. (2016). Cabal City: Regime Theory and Indian Urbanization. The Watson Institute for International and Public Affairs at Brown University Working Paper No. 2016-32.

${ }^{32}$ Gurgaon's urban villages, for example, are also symptomatic of neo-liberal governmentality "wherein powers and spaces are fragmented, creating unequal yet fierce territorialized forms of association" (Cowen, 2015). 
spaces of the urban elite are ultimately dependent on the greater city and its proximity to other cities or hubs, while the boundaries of enclaved spaces are also porous and permeated by people, objects and other aspects of social life (Srivastava, 2015). While "infrastructure" functions as an exclusionary technology of the built environment, the role of human beings and relationships in supporting the production of the city forces the gated community open in ways that defy succession from the greater city. Enclaves are seemingly discrete, but functionally dependent, and can never fully bypass the contexts in which they are "plugged in" or "cut and pasted" (Chattopadhyay, 2012). ${ }^{33}$

Along with its uneven development (Smith, 1984; Harvey, 2004), Gurgaon also offers a moral polemic, illustrating the ultimately self-destructive nature of accumulation through "the breakdown of the public good and primordial retreat into self-interest" (Srivastava, 2015). Urban villagers, the ancestral farmers of Gurgaon who sold land and became investors in the real estate game were also cast as part of a Faustian deal. As Cowen (2018) points out, the differentiated logic of capital accumulation in Gurgaon enabled farmers to make profits from the sale of their land, but still reportedly felt "looted" by Gurgaon's urbanization in ways that were difficult to articulate. Migrants lured by the promise of wealth found themselves excluded from prosperity. What is missing from these portrayals is an account of individual and collective processes of adjustment and change, meaning and value formation, that are in many ways outside the system of value presented by market logics, but ultimately

\footnotetext{
${ }^{33}$ Chattopadhyay, S. (2012). Unlearning the City: Infrastructure in a New Optical Field. Minneapolis: University of Minnesota Press.
} 
inform it, and the ways in which groups calculate the costs and benefits of abandoning, preserving or investing and ultimately fighting for place.

\section{Central Concepts}

1. Place and the Horror of Placelessness

While there have been many studies of place and its properties, there are fewer on its absence, or placelessness, let alone what either might mean for planners in the context of the rapidly urbanizing Global South. According to Relph (1976) place and placelessness are paradoxically intertwined. Place is implicitly characterized by distinctiveness, while placelessness, by sameness or monotony. ${ }^{34}$ When urban scholars and critics speak of placelessness, however, what they are often referring to is not a philosophical or psychological state of living without a point of reference, but a "sense of place" disrupted by the historical transformation of building practices and design in urban planning over the course of the 20th century. Placelessness, as an idea, is a way of capturing outrage and grief for places past. Relph (1976) argues that the quality of placelessness is a historical product, and an outgrowth of rationalism that took on an haute aesthetic form with modernism. After WWII, placelessness was mass produced and replicated across the world, often associated with fascist and socialist architecture, but also with high consumerism. Placelessness heralded modernity and progress as well as wealth and globality or "worlding" practices. ${ }^{35}$ It was synonymous with

\footnotetext{
${ }^{34}$ Relph, E. (1976). Place and placelessness. London: Pion, Ltd.

35 Worlding refers to the discussion among theorists of postcolonial urbanism and globalization, focusing on those practices which involve the appropriation, adaptation and evolution of global culture in contexts that were once dominated by Western imperialism, but now offer new models of urbanization and approaches to the "art of being global". Roy, A., \&
} 
rational imperialism and progress and wiping out the old reminders of poverty or feudalism, replacing it with uniformity and efficiency, erasing the distinctiveness of cultural or vernacular design. Brick and mortar shifted to metal, asphalt, concrete, glass, as the universal, industrial and cheap building materials of the modern age.

It also became clear that for as much as this idiom of placelessness seemed contagious, it was also despised. Jacobs (1961) championed the "organized complexity" of cities in her critique of placelessness in modernist planning. ${ }^{36}$ Years after post-war suburbanization and the middle-class flight from city centers in the US, UNESCO called for the protection of world heritage sites. Meanwhile, New Urbanist planning commodified the old "quality of place" as a "strategic business asset". ${ }^{37}$ This growing despair over placelessness fueled the use of "placemaking" and interreferencing as a design strategy in the mass production and sale of housing. ${ }^{38}$ In the US, commercial, walkable downtown redevelopment projects led to material improvements, as well as new hybrid places and multi-place experiences. This narrative of cultural convergence posits that as the world becomes more globalized, socio-economic and cultural practices also become disembedded from their original contexts. ${ }^{39}$ Kunstler (1993) describes the placelessness of suburban sprawl using a descriptor often applied to third world urbanism, the concept of entropy:

Ong, A. eds. (2011). Introduction. Worlding cities: Asian experiments and the art of being global. Malden, MA: Wiley-Blackwell.

36 Jacobs, J. (1961). The death and life of great American cities. New York: Modern Library.

${ }^{37}$ Relph, E. From the "Place \& Placelessness in the 21st Century City" (September 2014) symposium hosted by the UNSW Built Environment, People \& Place Research Cluster Workshop.

${ }^{38}$ Roy, A., \& Ong, A. eds., (2011). Introduction. Worlding cities: Asian experiments and the art of being global. Malden, MA: Wiley-Blackwell.

${ }^{39}$ Giddens (1991) argues that we are moving towards a more abstract world through processes 
"The immersive ugliness of the built environment in the USA is entropy made visible. It indicates not simple carelessness but a vivid drive toward destruction, decay and death: the stage-set of a literal "death trip," of a society determined to commit suicide. Far from being a mere matter of aesthetics, suburbia represents a compound economic catastrophe, ecological debacle, political nightmare, and spiritual crisis for a nation of people conditioned to spend their lives in places not worth caring about." 40

Friedmann (2003) took up these "entropic" forces of capitalist-driven, sprawling urbanism, which "steadily eat away at our sense of being anywhere at all, erasing our sense of place," but turned this critique to new cities of the Global South. He observed that the placelessness of the peripheries of Southern cities, and Northern ones facing the challenge of incorporating Southern migrants (i.e. Paris's banlieues), may exacerbate xenophobia and civil unrest. Friedmann (2010) defined place as:

"[A] small three-dimensional urban space that is cherished by the people who inhabit it" characterized by "reiterative social practices, inclusiveness, performability, dynamic quality...the place must be small, inhabited, and come to be cherished or valued by its resident population for all that it represents or means to them." 41

The emphasis here is placed on neighborhoods as the "primary space of social reproduction.” While "hotels, department stores, shopping malls, banks, airports, bus terminals and office buildings" become soulless non-places, juxtaposed to the inhabited places or domestic realms of the neighborhood as a public and communal extension of family life (Friedmann, 2010). To carry on Friedmann's project of theorizing place and placemaking in the Global South requires a careful reading of history. For starters, the placemaking discourse, particularly in the Global North, tends

of globalization (disembeddedness). Giddens, A. (1991). The consequences of modernity. Cambridge, U.K.: Polity Press.

${ }^{40}$ Kunstler, J. H. (1993). The geography of nowhere: the rise and decline of America's manmade landscape. New York: Simon \& Schuster.

${ }^{41}$ Friedmann, J. (2010). Place and Place-Making in Cities: A Global Perspective. Planning Theory \& Practice, 11(2), 149-165. 
to focus on outdoor public space, or concepts assumed to be universal, like the value of walkability. ${ }^{42}$ Hull's (2011) work on Delhi in the post-partition era highlighted the pitfalls of trying to map 1:1, US notions of the neighborhood unit onto an indigenous concept like the Mohalla. Colonial era planners were keen on using place-based cultural knowledge. After Independence, when the Ford Foundation was invited to work on Delhi's masterplans in the 1950-60s, the American agency hired a host of American sociologists to perform "social science operations," and to essentially train disparate populations in the principles of democracy and urban living through a brand of community development. The methodology focused specifically on generating new place-based solidarities that transcended (or erased) past meaning. In Hull's (2011) telling of the history of Delhi's community development projects after partition, the problem was not that rural populations couldn't cohabitate in an urban context per se or that theories of place-based community didn't apply to India, but rather, throughout its history with the West, place and its attachments on the Indian subcontinent had been used to manipulate and rule South Asian publics. New or more rigid attachments and identities were often imposed through physical planning and apolitical community development without addressing larger structural issues of poverty and inequality. While the aim here is to contribute to a grounded theory of place in relation to planning praxis and community development, this requires a more inductive approach to not only what constitutes "place" in the eyes of participants, but also what affective tropes have significance to people in situ.

\footnotetext{
${ }^{42}$ Strydom, W., Puren, K., and Drewes, E. (2018). Exploring theoretical trends in placemaking: towards new perspectives in spatial planning. Journal of Place Management and Development, 11(2), 165-180.
} 
When Friedmann (2010) speaks of the "horror of placelessness" he evokes an emotion typically reserved for moments of crisis. Horror combines a potent sense of fear, as well as disgust, at the manifestation of one's fear. It speaks to the embodied and often epidemiological crises of slums, i.e. open defecation, poverty, overcrowding, or flooding. ${ }^{43}$ These types of horrors also present empirical problems of the body and its well-being. For many, these places are also home, if temporarily, where they must raise their children, sleep, cook, play, rest, and find enjoyment in everyday life. Kunstler (1993) argued that placelessness is not just an issue of aesthetics, but that suburban landscapes "compound economic catastrophe, ecological debacle, political nightmare, and spiritual crisis." In the most generic of built environments, however, i.e. the strip malls or McMansions of American suburbs, one finds evidence of demographic transformations, and assertions of placemaking among economically and culturally diverse communities who may fundamentally disagree about what sorts of densities and suburban aesthetics are beautiful or bring joy to everyday life (Lung Amam, 2017). ${ }^{44}$ Over time, social and cultural change and difference can begin to re-inscribe the monotony of modern placelessness with new forms of meaning. Therefore, I am inclined to agree that it is important to take place and its antithesis out of the realm of pure aesthetic and the ways in which spiritual crisis and ecological debacle can and often do coincide. One must be careful with the

${ }^{43}$ Davis (2006) references Conrad's Heart of Darkness, describing the slums of Kinshasa which "seem to take us to an existential ground zero beyond which there are only death camps, famine, and Kurtzian horror" (p. 198). Davis, M. (2006). Planet of slums. London: Verso.

${ }^{44}$ Lung-Amam, W. S. (2017). Trespassers?: Asian Americans and the battle for suburbia. Oakland, California: University of California Press. 
word entropy, as Jacobs (1961) cautioned. While the participants in this research do express horror or disgust/dread at the failures of the built environment (i.e. pollution, congestion, environmental degradation, poor housing conditions, etc.) their reflections also offer multiple ways of experiencing or conceptualizing place and placelessness, and the worth of places, as well as what is to be done; attempts to protect, fix, renegotiate, make do and plan as ordinary citizens. Placelessness has an aesthetic register, particularly for research participants in design professions, but throughout the dissertation it is aligned with how research subjects understand it. The aim in this dissertation is not to speculate on what makes the ideal city, or propose a set of onesize-fits-all parameters for the Indian suburb, but rather to present multiple notions of place or placelessness from the perspective of those who experience them in everyday life and to theorize from those imbricated points of view.

First, the dissertation argues for the significance and usefulness of a placebased analysis in community development. The dissertation demonstrates this through a sustained reading of the social construction of place and how a sense of place emerges in different contexts, producing the contradictions of material and symbolic reproduction among diverse communities who share spaces of the city. None of these groups is monolithic, and their actors offer diverse conceptualizations and aspirations for those spaces as places of meaning and value. As space and place are often shared, the chapters demonstrate the ways in which encounter, cooperation and conflict can produce intersectionalities of place and place-based identities that complicate notions of civil society and citizenship. Finally, by discussing the social construction of place as attachment, or in other words, as a relationship, one taps into a range of insights on 
the role of social practice that can help to bridge the individual with common and shared needs for belonging, security, and self-actualization across disparate communities. Understanding place as relationship allows us to consider the agency and action of ordinary individuals in resolving planning problems, a process I often refer to as the politics of placemaking.

\section{The Social Construction of Place vs. Place Attachment}

"Attachment is a subjective, invisible attribute...it may become visible when a neighborhood is threatened by demolition...or when its social composition changes rapidly, and the integration of newcomers becomes stressful and problematic"

-Friedmann (2010)

For the purposes of this research, place refers not only to the physical or built environment of Gurgaon, but the narratives and activities surrounding those environments. While place narratives have emotional resonances, they are also rational cognitions or forms of knowledge: truths, beliefs, practices, or statements about objects, locations, or the self. When we discuss a place narrative, we are putting information into a kind of schema, organized in such a way to tell a specific story and make sense of the world (Bartlett, 1932; Markus, 1977). Both the glossy branding of developers and the Chief Minister's indigenization of the city's name from Gurgaon to Gurugram, serve to reinforce their own schemas or ways of making sense, even forcefully asserting, a kind of place narrative. Chapter 2 focuses on the central place narrative of Gurgaon and its construction alongside the material production of Gurgaon's changing landscapes. 
The construction of place narratives are just one component of what I refer to as placemaking, which I discuss throughout the dissertation as a process that involves a range of practices that invest spaces with meaning and value (Pellow \& LawrenceZuniga, 2008). ${ }^{45}$ Planners, urban designers, and real estate developers do take this seriously. Identifying meaning, symbols, and certain aesthetic preferences aligned with the values of their potential end-users is necessary. ${ }^{46}$ However, there is an inherent tension between a place's use value to its inhabitants and its exchange value as a source of revenue for a developer (Logan \& Molotch, 1987). This tension plays out not only in issues of overbuilding and speculation, but in the quality and presentation of urban design. As one resident, who also happened to be an architect, put it, "There is no architecture here, only buildings." Placemaking as a kind of commodity offered by a design firm, for example, may consider which amenities and environmental elements will please or provide the most comfort and happiness for the potential end user or promote a "sense of community". The interpretation of "place" by both builders and inhabitants matters. How they coalesce depends a great deal on a conversation between the builder and their imagined users. This dialogue, however, is often distorted. Local zoning codes, ordinances, design councils, committees, government bids and requirements often act as constraints and interpreters. They give direction towards compliance with a master vision. For architects, placemaking can also be about building an armature that allows other processes to occur through or

\footnotetext{
${ }^{45}$ Pellow, D., \& Lawrence-Zuniga, D. (2008). The Self-Consciousness of Place-Making, Anthropology News.

${ }^{46}$ The Project for Public Spaces Inc. (2002). How to Turn a Place Around: A Handbook for Creating Successful Public Spaces. New York: NY.
} 
around it. This armature can anticipate uses (and use value), as well as the processes that go into shared history and incremental alterations to the built environment. While thinkers and critics such as Jacobs (1961) and Lynch (1960) observed lively urban environments and inductively thought through the ways in which the built environment supported dynamic processes of placemaking, the reproduction of these ideas has taken the reverse approach. For example, new urbanist design offers predetermined features assumed to generate dynamic social processes and placemaking (Wohl, 2017). ${ }^{47}$ Like urbanization itself, placemaking is an ongoing and unending process. It can involve reimagining or remembering something or changing the language and terms around which it is described or used. Placemaking can be an abstract activity that involves layering a level of meaning on top of a space or stage without physically altering it. It can be a new way of seeing something, or a new set of rules for negotiating it (Friedmann, 2010).

Individuals and communities participate in systems of meaning that explain the world around them. The choices we make as consumers reflect or are consonant with a set of values that speak to that meaning. Marris's (1974) seminal work on bereavement in the face of loss continues to provide an important way of understanding the response to moments of disconnect, disappointment and failure in the built environment. Disruptions to the meaning associated with one's environment can trigger moments of tremendous anxiety and disappointment, as well as attempts to course correct and restore assumed value. "We assimilate new experiences by placing

\footnotetext{
${ }^{47}$ Wohl, S. (2017). From form to process: Re-conceptualizing lynch in light of complexity theory. Urban Design International, 22(4), 303-317.
} 
them in the context of a familiar, reliable construction of reality. This structure in turn rests not only on the regularity of events themselves but on the continuity of their meaning" (Marris, 1974, p. 6). For a "reliable construction of reality" to become radically altered or disrupted, poses a new risk to the integrity of that meaning.

The response to this disruption can be twofold. It can produce a will to restore or preserve the previous assumed reality as well as a will to change or adapt. While humans are incredibly adaptable and resilient, Marris writes, "[T]he conservative impulse appears more pervasive and profound than simple prejudice or class interest. It is as necessary for survival as adaptability: and indeed, adaptability itself depends upon it." The "conservative impulse" is also a useful tool in understanding placemaking as a response to change. In his discussion of bereavement, Marris observes that change forces us to adjust so that our old systems of meaning, the ways in which we interpret the world around us can remain in place and accommodate some new information, a shift in environment, in the norms, traditions, livelihood generation, or the introduction of new technology. This helps make sense of dual strategies (of both conservation and innovation) among different groups, institutions and communities.

It's possible to understand place and practices of placemaking in Gurgaon as the mass working out or processing of change and reintegration of new information and meaning. For example, gating is both a symbolic and material act of reproduction, demarcating territory and property in the face of some real or imagined threat. To what extent do the visual and cultural reminders of poverty interrupt or contradict an idea of prosperity and egalitarianism? Disgust or revulsion is often the other side of an innate 
fear and a need to become invulnerable to it (Nussbaum, 2004). Is it possible that the desire to gate out the visual reminders of poverty comes from an only superficial disgust, that belies a deeper shame, guilt or even fear of poverty and its aesthetics? In this sense gating is not just a literal act of protecting wealth or assets, but a psychological act of self-preservation, and conserving narratives of the self against the threat of change or loss.

Applying such anxieties to the notion of place-attachment and we might go a step further. Marris was influenced, to a certain extent, by psychological models such as Bowlbian attachment theory. At the most basic level, place-attachment is a bond between a person and a place, one of the foundational concepts in environmental psychology, often characterized as a fundamental human need (Scannell \& Gifford, 2010). John Bowlby was a developmental psychologist working in the middle of the 20th century, who studied infants and parent-child bonding relationships. His theories of motivation and behavior control, now widely accepted, broke with traditional theories, i.e. Freud's notions about the mind of infants, and were grounded in evolutionary biology and animal behavior, looking at people as highly evolved beings with fundamental and evolutionarily driven needs and tendencies to form attachments to primary caregivers.

Over the latter half of the 20th century, the theories of human bonding and attachment began to breach into questions of material reproduction, and scholars began to ask questions about how human beings form relationships with their environment using this framework. Just as there is no single definition of place, or placemaking, there is no single paradigm or general theory for place-attachment. The 
study of such phenomena requires a reckoning with the same complex task of defining place faced by geographers, planners and other social scientists. In fact, behavioral psychologists have looked to other social sciences for definitions to inform empirical research on emotional attachments to specific locales, and attachments to the social contexts that constitute them. The places that individuals find meaningful represent a broad range of physical settings, from built environments such as houses, streets, buildings, and non-residential indoor settings, to abstract places, such as a city, state or country, and different types of "natural" environments (Manzo, 2005). Manzo (2005) notes " it is not simply the places themselves that are significant, but rather what can be called 'experience-in-place' that creates meaning', (p. 74). Geographers also describe place belongingness in affective or emotional terms. Tuan (1974), for example, coined "topophilia" or "love of place" to describe an emotionally resonant and bounded location in a human life.

Among urban sociologists, the concept of place attachment is inherently a social construct and is often described with phrasing such as "a sense of community" (Hunter, 1974; 1978; Gans, 1962; McMillan \& Chavis, 1986; Perkins \& Long, 2002). In terms of scale or the spatial/geographic unit of analysis, sociologists locate these attachments at the city, home, and neighborhood levels (Kasarda \& Janowitz, 1974). However, the scale at which we measure place attachment, the way it is often discussed, seems to be culturally relativistic, hence the need to think contextually, to acknowledge the neighborhood unit, but also develop a grounded understanding of place that critically considers what place means through specific cultural contexts and what its significant units and scales might be (Hidalgo \& Hernandez, 2001). 
How might planning draw on or support these needs or learn from the behaviors that come from them? How could these lessons better inform planning theory and practice? Out of the morass of this literature and possible applications for planning, I will focus on a few concepts that help in reading Gurgaon and will appear throughout the chapters. It is not simply that places have meaning for individuals and social groups, although individual vs. group level attachments overlap. Place-based meaning also helps shape the dimensions of the self and society. On the most basic level, personal histories and timelines support the functioning of the mind. The spatialtemporal link, or "place-referent continuity," between memories and places are cognitions that allow for a stable "self-concept" (Twigger-Ross \& Uzzell, 1996).

The construction of meaning for residents or migrants, relating to a new city or place, is deeper than a feeling of attachment, and satisfaction or dissatisfaction with that new environment. There is a basic self-definition that is being tested or worked out. Placemaking may require a renegotiation of that self-concept. However, there is no consensus on how this works. Simply knowing a great deal about a place, i.e. familiarity, can constitute a form of attachment (Fullilove, 1996). ${ }^{48}$ Some argue that meaning itself is the object of attachment, or the medium through which this bond is formed, i.e. people become attached to the meaning associated with a place and its characteristics (Stedman, 2003). For example, individuals can be attached to the very idea of a type of place or "settlement identity", such as a rural house, or a suburban enclave (Feldman, 1990).

\footnotetext{
${ }^{48}$ Fullilove, M. T. (1996). Root Shock: Psychiatric implications of displacement. contributions from the psychology of place. American Journal of Psychiatry, 153, 1516-1523.
} 
This meaning (connections, memories, etc.) has both symbolic and material significance in everyday life. ${ }^{49}$ In terms of symbolic importance, we interact and form social bonds through space and place and the existing social groups they represent (Lalli, 1992). Place facilitates the practice of culture and religion. Therefore, scholars suggest that place attachment or place dependence is augmented by ancestral ties, or the feeling of being an "insider," which supports a desire to stay in proximity to places (Hay, 1998). However, place attachment also supports physiological needs for safety and security. When residents speak of amenities, services, the quality of life in a specific locale, they are speaking of material supports and the ways in which places provide for their basic needs, as well as aspirations. The attachment doesn't satisfy needs on its own, but rather functions as a system designed to keep us in contact with the resources and social bonds that meet other basic physiological needs (Stokols \& Shumaker, 1981).

Human beings also have a need for temporal continuity, where the past will inform the future, and environments can be predicted. Having a stable relationship to place "allows for cognitive freedom," which exists when we are not in a state of crisis or overworking to regulate and manage emotional states in response to environmental stress. A healthy connection to place enables rest and the ability to restore and maintain a sense of well-being, even in times of crisis (Korpela, 1989).

In contrast, the immigration and refugee literature look at the effect of displacement and diaspora on well-being and cognitive freedom, the feelings of

\footnotetext{
49 Place attachment has something in common with what Biologists call "home range," referring to an area that animal considers or would defend as part of their territory, not necessarily migratory paths.
} 
homesickness or longing for lost places that arise from prolonged separation (Deutsch, 2005). For example, Fried and Marris (1974) made observations about the emotional effect of displacement on slum-dwellers in Nigeria. Fullilove (1996) also found that displacement results in feelings of sadness and longing. Just as attachment behaviors are stronger among vulnerable individuals (e.g., someone who is pregnant or sick), Fried (1963) suggested that place bonds are often more intense among vulnerable populations (e.g., migrants). Losing one's home by force, in the case of evictions, for example, even without the threat of homelessness, is an "exquisitely shameful experience," and can pose a traumatic sense of rejection, increasing risks for suicide and ongoing depression (Desmond, 2016, p 298). ${ }^{50}$

Place-attachment is not a passive bond, but also influences behavior, i.e. placeprotective behaviors, place-enhancement behaviors and place-inspired behaviors (Scannell \& Gifford, 2010). The most common of these is simply maintaining proximity. When we think about the concept of homesickness, it speaks to this need for closeness with the object of the attachment. Sometimes this need for proximity is more flexible. Bowlby (1970) observed that individuals experience conflicts between conservative and progressive impulses. When a child goes out and explores, if they have a safe and secure place to return to, they are better able to adapt. According to Marris (1974): “Adaptability seems to depend ... on the interaction of two contrasting qualities. Without confidence in the continuity of our purposes and sense of the

\footnotetext{
${ }^{50}$ Desmond, M. (2016). Evicted: poverty and profit in the American city. (First edition.). New York: Crown.
} 
regularity of social behaviour, we cannot begin to interpret the meaning of any [new] event."51

We have a desire for security as well as adventure and inquiry, and adaptation requires there to be a certain relationship between these two activities. Someone with a more secure attachment to a place may have an easier time leaving that locale and coming back, or they may work to recreate that place in a new location. ${ }^{52}$ Therefore, place reconstruction is also an important practice that emerges from this attachment (Scannell \& Gifford, 2010).

The ways in which place-attachment forms, its strength, security are not just emotional states, but involve the working through of real, imagined and remembered places existing simultaneously for the individual. The everyday nature of attachment is action, making choices, telling stories, the ways in which we describe or characterize problems, including planning problems, and identify and decide when those problems have been solved. They determine the extent to which we invest in improving places, and in altering them, the tastes and preferences we apply to those alterations, the communities we associate with and so on. We bring the places we come from with us to new homes, the values formed in those previous locations determine the choices we make as consumers and citizens, and ultimately planners. I explore the construction of meaning for participants, and the practices that constitutes placemaking as the

\footnotetext{
${ }^{51}$ In Marris's application of the concept, adaptation comes spontaneously to the threat of disruption, as an effort to prevent further change.

${ }^{52}$ Scannell, L. \& Gifford, R. (2010). Defining Place Attachment: A Tripartite Organizational Framework. Journal of Environmental Psychology, 30, 1-10.
} 
essential work of having, building, and maintaining attachment; the activity or practices that helps us hold on to, create and safeguard ourselves and our communities.

Taking cues from place-attachment theory in studying the social construction of place involves viewing place as a reflexive relationship, recasting actions that invest or support the creation of place (and the elements of citizen planning), as relationship building, maintaining protecting etc. These become, by extension, solipsistic activities of maintaining the self through others and the material world.

3. Community, Class Identity and a Place-based Analysis

The social groups or communities in each chapter are heterogenous but fall broadly into several kinds of place-based relationships. For the purposes of clarity here, those groups consist of 1.) affluent renters and homeowners in the formal housing market, 2.) the ancestral landowners and now rentier capitalists of Gurgaon's informal urban villages, 3.) a large floating population who rent informal housing in villages, and 4.) government officials who reside in Gurgaon on temporary posts, attached to their agency of employ. These cohorts are discussed at length in South Asian scholarship and the Global South literature more broadly, but the research here focuses on the ways in which subjects self-identify as members of larger or multiple communities and social categories or demographic groups.

The word community has multiple uses throughout the dissertation. Apart from broader notions of class, kinship, caste, religious membership, or common language, residents use the term as a shorthand for a gated housing development, but also for the people who live within them. Early in the research, I identified several ways of categorizing community, following Hull's (2011) distinction in the Delhi episode. The 
first was a broader net for "communities of interest" (economic interest), primarily groups who shared assets such as membership in a common interest development or Resident Welfare Association (RWA). ${ }^{53}$ The second related to proximity, or "communities of place", in which members may be connected through geographical origin, but also through relationships that evolve directly from proximity. These did not necessarily depend on common interests or membership in a pre-established community. This form of community is problematic, as Hull pointed out, because it romanticizes encounter itself as the basis for recognition and friendship, without acknowledging the ways in which everyday encounters require negotiation, interaction and cohesion between people living near one another. The dimensions and tenor of those interactions do matter, and in some cases may require that those living near one another already belong to a similar or economically dependent groups. Finally, "communities of kind" applied to broader groups, loosely connected through a shared set of values, lifestyle, or belonging in some imagined i.e. linguistic, community (Anderson, 1992). Residents who participated in NGOs and other social causes, friends, families, neighbors, with some bonds that transcended paid membership in an RWA made sense here. However, I also began to recognize the ways in which the demands of managing an interest-based group, such as an RWA, might create factions or fault lines between members of the same community, households, etc., therefore

\footnotetext{
${ }^{53}$ One could argue anyone who lives and pays taxes within a municipality are members share a common interest in terms of the use and allocation and reinvestment of those revenues in public works, however RWAs as homeowners associations are smaller and based on shared revenue where there are no "free riders" who may benefit from the investments of the other members of the group without making a contribution or paying an entrance fee of some kind, hence the term "club good" often applied to these types of cooperative societies.
} 
cohesion or solidarity, simply "getting along" was possible in a community, but it was by no means a prerequisite or basis for definition. Outside of property-based organizations, which were also ultimately place-based, the middle-class civil society of Gurgaon was networked through organizations that often communicated via social media (Facebook, google docs, WhatsApp and so on). These networks subsidized a lack of common locality or centered around remoter locations (places of meaning and value) outside the home, such as the Aravalli biodiversity park, cleanup sites, the nearest mall, or stretch of road or urban village where NGOs might conduct their activities.

During research, these various kinds of community began to blur together and lose their salience. The relationship between place and kind was often overlapping. For example, to be able to speak a common language with one's neighbors already establishes several commonalities and membership within a certain group, i.e. those who received English language education. In the case of migrants from a common sending region who did not previously know one another, families might form new relationships based on both a connection to a home state and similarities in linguistic and socio-economic/migration stories that brought them into proximity in a receiving location. ${ }^{54}$ The constantly evolving nature of place and community made grand theories of community feel rigid and imposed. By focusing on urban space and the social construction of place, it became easier to consider what community meant or looked like for research participants, rather than deducing it from afar.

\footnotetext{
54 "Sending" and "receiving locations" were the terms used by migration NGOs to refer to migrant origins (sending locations) in terms of state, village, region etc. vs. the destination (receiving location).
} 
I began to study the relationship between physical planning and community development in Gurgaon from the vantage point of gated colonies, and therefore focused initially on issues of placemaking and its relationship to identity and community among a generalized notion of the Indian middle classes, the focus of Chapter 4. Class-based visions and conflicts over territory and urban planning are central to debates in the scholarship of Indian cities. Much of this scholarship argues that "middle-class," is an elastic category. Like the other concepts laid out here, it has a simple definition that begins to expand on inspection, and this elasticity and discursive vagueness allow for a larger theoretical debate on modernity, globalization, and neoliberal consumption. To explore the middle-class imaginary around place, or what place means to the Indian middle-classes, and how this translates into action requires setting out with a coherent definition. However, it is important to acknowledge there is no consensus on what it means to be middle-class in India, even in basic economic terms. Some criteria allow for over $50 \%$ of the country to fit the description, while other measures put it at 6\% (Lemanski, 2012; Sridharan, 2004). ${ }^{55}$ Some definitions point to income, while others look at consumption patterns, education, types of employment, residency etc. To complicate this further, selfdefinitions tend to encompass a much larger range of households who identify as middle-class than the economic portrait suggests, although some of this selfidentification is aspirational.

Part of the reason "middle-class" (or any class, for that matter), is so difficult

\footnotetext{
${ }^{55}$ The middle-class income threshold in India is roughly equivalent to $\$ 13,000$ (US). Several self-identified middle-class participants in the research reported earnings in the hundreds of thousands USD per year.
} 
to define through a single indicator (income, consumption, education etc.) is that the boundaries of class are socially constructed, and the members share a graduated and internally hierarchical status. Arguments about Indian cities and participation or citizen planning could easily fall back on a binary separation between the elite and the poor, with little in between. Therefore, it is important to be aware of the distinction between Chatterjee's "new middle class" and Lemanski's "missing middle" (the lower middle-classes) and how these groups shade into one another and differently inhabit and construct place in cities (Lemanski, 2012). The so-called "new-middle class" could more accurately be identified as elite, "exemplified by glitzy shopping malls and international travel" (Chatterjee, 2003). However, Chatterjee (2003) also acknowledges the variation within the concept that "in fact conflates India's new (and tiny) globalized elite with the large and heterogeneous middle-class comprising a wide range of incomes and practices, within which elites are a small component."

This cohort seems to have emerged in the 1990s and began to stand out in planning and urban studies scholarship for accessing the state through propertied membership in housing societies such as Resident Welfare Associations (RWAs). As a form of network governance, RWAs have a democratic ethos but are exclusive networks that lobby on behalf of their members. RWAs have come to dominate Gurgaon's politics (the city hosts some of the largest RWAs in India). While working with them is often necessary, scholars have also cautioned a growing reliance on RWAs as proxies for civil society. Ghertner (2011) critiqued Delhi's bhagidari scheme, a public participation program that allowed RWAs to form direct relationships with bureaucrats and local authorities. The relationship between RWAs 
and local government ultimately rewarded a middle-class electoral minority with premium access, what Lemanski and Lama-Rawal (2012) have called a "class-based vision of democracy for the city as a whole," a process Ghertner (2013) refers to as the "the gentrification of the state". Members of these groups are viewed as model or concerned citizens, while the lower middle-classes and the poor, or Chatterjee's "political society", are treated derisively by bureaucratic government as populations (Lemanski, 2012; Ghertner, 2013).

Beyond their work in RWAs, the middle-class have also attracted scholarly rebukes for environmental activism in Delhi, a thinly veiled class-based attack on the urban underclass via the cosmetic reminders of subaltern physicality in the city (Baviskar, 2003). I take up the concept of "bourgeois environmentalism" to a certain extent, as an example of the ways in which material and symbolic reproduction begin to coincide through placemaking, and in the case of environmental activism, placeprotective behaviors, that highlight the ways in which class norms, expectations, and fears, coincide. In Chapter 4, I focus on this kind of environmental consciousness, drawing from Lemanski's (2012) expansion of middle-class beyond a socio-economic category, as a kind of ideological or normative position and "vision of India's future society." Similarly, Deshpande (2006) speaks of the middle-class as a "moral majority," not an actual majority, "that occupies a hegemonic position insofar as they represent India's modern aspirations: educated, upwardly mobile, with westernized consumption patterns (but not necessarily Westernized values)." Fernandes (2006) also speaks of this cohort as "consumer citizens". 
Gurgaon's ostensible "other middle-class," the former agriculturalists of Gurgaon District who remained as rentier capitalists in its urban villages are a curious exception to the binary. Caught in a position of recent privilege (high incomes, political clout), these communities are also self-identified OBCs, of several sub-caste groups, who may or may not "get along". Throughout research, these communities were distinguished from the other affluent classes. Much of their wealth and power is non-portable, and deeply tied to their control of abadis $^{56}$ where they collect rents and vote. In many ways, the story of the ancestral Gurgaonwalla making and maintaining place is the most striking. These are communities who were often historically pastoral or driven out of other states before Haryana was formed. They became revenue sharecroppers in the 19th century at the behest of the colonial project, growing crops that were often ill-suited to the land. While Haryana became a state in the 1960s, Haryanvi was never recognized as an official dialect or language. Throughout fieldwork, participants, including members of these communities, shared views about the backwardness of Haryanvi people, whose consumption practices and performance of new affluence, was often derided.

By contrast, in Chapter 6, migrant households living in the spaces of the village as informal renters, comprise the urban underclass of Gurgaon, who indeed make up most of the city's population. Most of the participating low-income migrant households in this research are temporary residents, raising families and living invisibly for years in Gurgaon. It is important to ask what this long-term temporariness

\footnotetext{
56 "Abadi deh" refers to an inhabited part of a village, or the village core, which is distinct from common land or private holdings.
} 
means for the city. Does Gurgaon feel like a waiting room for economic prosperity among its poor, for whom economic ascension will always be painfully out of reach? A place-centered analysis has something meaningful to say to migrants in precarious living conditions in the city. The research finds some agency in the "working life" migration strategy, even among those who have been discriminated against or excluded from urban political participation and citizenship. As is often the case, lowincome migrants from rural villages have often undertaken this difficult invisible citizenship in cities as part of a joint or multi-generational income diversification strategy. If considered subalterns, these migrant populations are not always "doubly free" in the Marxist sense, but still have strong landed connections they wish to conserve by sending remittances back to their families, returning to vote, give birth or find a spouse. By leaving, temporarily, they make the older agrarian way of life leaner and less burdensome for their growing families and retain those remaining ties and a portable sense of purpose in a precarious place like Gurgaon. This is not an easy argument to make, however. Some of the most compelling work on slum-dwellers disavows any romantic longing a rural migrant has for "home". When they are excluded, it is also often under the pretext or presumption of migrant status and a "dual loyalty," as in the case of long-time Bengali speaking Muslim communities in Delhi (Baviskar, 2011).

The urban underclass in India, Chatterjee's (2003) political society, is often the largest vote bank in the city (Harriss, 2005). ${ }^{57}$ When politics fail them, the agency

\footnotetext{
${ }^{57}$ Harriss, J. (2005). Political Participation, Representation, and the Urban Poor: Findings from Research in Delhi. Economic and Political Weekly, 40, 1041-54.
} 
of the urban poor, and their avenues for self-determination in the city, is often discussed through the reliance on horizontal networks, NGOs and apolitical routes to better living in urban slums over time (Appadurai, 2002). Some of these routes rely heavily on claims to land and secure tenure in the city. For example, Benjamin (2008) observed the ways in which squatters and slum dwellers subvert land use planning's grand schemes. As a framework, "occupancy urbanism” recognizes the incrementality of places, that rarely emerge from one "hegemonic" plan, and the complex nature of tenure arrangements in Indian cities. This form of urban citizenship, however, requires embeddedness (awareness of how the system works) and political legitimacy, where the urban poor can put pressure on local politicians to serve their interests.

Similarly, Bayat's (2013) “quiet encroachment” sees “silent, protracted but pervasive advancement of the ordinary people on the propertied, powerful, or the public to survive and improve their lives." By appropriating property laws, the urban poor achieve a gradual process of legitimation, working the system itself through a hallmark of neoliberal governmentality: state policies focused on property, its protection and commodification. The ability of "ordinary people" to access space and real estate surpluses illustrates that there isn't a global hegemon, but rather, processes that can be subverted by the local, the poor, and by this type of ground up encroachment. ${ }^{58}$ The research finds limited interests on these fronts in Gurgaon. Informal settlements are quickly demolished when they encroach on private or public

\footnotetext{
${ }^{58}$ Looking beyond India to the urban peripheries in Sao Paulo, Holston (2007) observes the struggles of the underclass are no longer tied to labor movements as they are to questions of tenure and land, of urban citizenship. Holston, J. (2007). Insurgent Citizenship: Disjunctions of Democracy and Modernity in Brazil. Princeton, NJ: Princeton University Press.
} 
lands in Gurgaon. Residents are suppressed as voters by landlords or discouraged by the politics. While NGOs assist in "working the system," the urban poor face competition for land surpluses not only with the hegemony of real estate development and neoliberal planning, but with the very people they rely on for shelter--the urban villagers. But listening to oral histories of migrants from the angle of place and attachment, begins to trouble the notion that individuals, households, or communities who often lack material security of tenure, or a place of their own in the city, lack a sense of place or belonging in a broader sense. In the accounts of low-income migrants, were stories of a strong and clear connection to an idea of home, but also a sense of purpose in being in Gurgaon, and a temporal relationship to place that differed substantially from that of those who were invested in the city for life. Furthermore, migrant participants were often wary of or intimidated by those communities, households, families, who guarded jhuggies from intruders and looked out over the row of hutments as though it were a field of millet to be tended.

To address the challenges posed by any of these groups is difficult without looking at the continuities between them. They occupied the same land, and share political and economic dependencies, patronage relationships, and a common citizenship (often obscured by difference). Because of this common ground, any attempt at self-preservation, definition, or actualization through place and placemaking, forces one to bump into someone else, to interact and negotiate. Acknowledging the importance of the ontological and historical distinctions between different communities of class, caste, place, kind or interest, but also the common salience and importance of place, requires some dialectical thinking and analysis. 
Managing conflicts among disparate communities often requires the identification of "common interests" while maintaining respect for difference, without attempting to forcefully blur the lines between different groups or ask them to recognize each other as members of the same community. Both realities, difference and co-habitus, must be allowed their truth in order to articulate a way forward. Marris (1974) concluded that to accommodate diversity, we must recognize the inevitability of conflict, and its necessity for groups. Insurgence is as much a part of democracy, or a stage in it, as consensus. Ambivalence can become a managed condition in which one must respect difference and not try to overcome it or overshadow identity. By recognizing the necessity of transition, loss and change, perhaps planning can help. "Thus, the management of change," writes Marris, "depends upon our ability to articulate the process of grieving." Marris gives us this "bottom line": "[I]f we do not know how to mourn, we cannot know how to live...."

\section{Organization of the Dissertation}

The organization of the dissertation follows the spatial and temporal logics of the city as place or as a composite of places. The first part of the dissertation, Chapters 2 and 3, present the representational and institutional framework that undergirds planning and placemaking in Gurgaon. Chapter 2 considers Gurgaon's central place narrative, the Millennium city, and traces its origins and evolution over the latter portion of the 20th century. I argue, in line with Searle (2016), that the Millennium city brand, the "theater of dreams," is as much a semiotic project, as it is a material one. As Searle (2016) argues, the language and representations of this market (for 
land, housing and amenities) are not epiphenomenal to it. The juxtaposition of image and reality, as Crestani's photographs explore, is part and parcel of that market. I extend this argument, however, by looking at the moving parts within the place narrative, the hero myths that require protagonists and antagonists to accomplish their work. The blank slate on which Gurgaon evolved, is a formerly agrarian one. Its history under colonialism and into the middle of the 20th century, is an environmental one, that involves the discursive and material construction of a wasteland (banjar) and its place narrative. I argue that the Millennium city brand acquired heroic dimensions in contrast to the preexisting landscape and its people, who were either antagonists or victims in need of intervention. This argument was used on the ground to convince farmers to part with their lands and buy elsewhere or become investors in the Delhi Land and Finance Corporation's (DLF) real estate projects in the 1980s. This narrative also takes up narratives of corruption and public waste in the earlier government-led projects of industrial and urban development in the region. The Millennium city is positioned as a rehabilitation of a rural wasteland, and the private-led solution to corrupt or ill-conceived government planning of the 20th century.

Chapter 3 shifts to the present day, when the decentralization of urban governance has put the planners back into the fray of the private city and its politics. I discuss the professional world of planners in Gurgaon tasked with carrying out the edicts of real estate development, cycling through short-term posts, the so-called “transfer raj". I consider the placelessness of planning itself, as a neutral administrative practice in India, that discourages embeddedness and the lure of corruption associated with it. In Gurgaon, multiple agencies vie for control over the 
planning agenda and various territories that have yet to be integrated, while the minutiae of planning or "micro-planning" has largely been outsourced to the private sector. This has inadvertently privatized not only the process of building and maintaining housing and infrastructure, but also the process of accumulating contextual or place-based knowledge and social capital with local communities.

Chapter 4 shifts to the residential spaces of the city and the social construction of place and citizen planning among residents of DLF and Nirvana country gated colonies. The model gated communities of Gurgaon, with their amenities targeting middle-class needs, appeal to certain notions of comfort and stability. Residents in DLF and Nirvana Country colonies discuss their relocations to the city, the establishment of a household, and various moments of enjoyment, stress, discomfort, and comparison. These responses drove them to act in different ways. These episodes intersect with various aspects of citizenship, as a form of place-based identity, as well as property (and location) based common interest groups or RWAs. Finally, the chapter looks beyond RWAs to other forms of social organization around placemaking, including environmental activism rooted in the task of emplacing Gurgaon.

Chapter 5 explores another kind of middle-class enclave, examining Gurgaon's urbanization from the vantage point of the village and the villager cum landlord. While the drama unfolding in gated colonies is more visible and certainly widely documented in the media coverage of Gurgaon, its urban villages seem to be hiding in plain sight. Undocumented in master plans, they present islands of exception in which villagers retain complete control of the built environment but find themselves caught in a paradox of underdevelopment (Cowen, 2015). The villages remain spaces of 
informality, including informal tenure relationships between low-income migrants and their landlords, threatened by the prospect of losing their political majority. Villagers stage protests and actively participate in formal electoral politics of the city, running for office in Gurgaon's emerging municipal government and ward system, while they stand off with municipal favoritism towards DLF housing and its encroachments. To untangle this story involved looking at what it means to lose place in situ, for those who never moved, for people who willingly sold their lands and regretted it many years later. The decision to give up farming, in many cases, and shift to rent collection, was a massive transition for an older generation, who lacked formal education and had watched these spaces utterly transform over the course of their adult lives. For their children, it was a different story. The village had become more of an abstract tie to ancestral histories, than an immediate identifying anchor.

Chapter 6 remains in the village, but makes it strange, following the perspective of low-income migrants. The chapter discusses the conditions of internal migration in India more broadly and looks at specific patterns in the case of Gurgaon. Low income migrants in Gurgaon find themselves in a situation of political invisibility, in which their long-term temporary status ensures that they are not counted in census data or included in formal planning and resource allocation. This continued status as newcomers or outsiders, unaccounted for in the official population, has reflexive implications for their employers and landlords and the city more broadly. Chapter 7 concludes the dissertation observing the confluence of its historical wasteland narrative with recent efforts to restore its original biodiversity and resulting class and institutional clashes over public space and the ethos of the city itself. I return 
to the original argument about the ethical and epistemological challenges of problematizing and approaching planning failure in the context of the bad or unlivable city of the Global South. I reiterate the ways in which the various place-based stories of citizen planning, socially constructed antinomies and the social construction of place can contribute to planning theories and theories of planning practice. 


\section{CHAPTER 2: THE PLACE OF NARRATIVES IN GURGAON'S HISTORY}

\section{Introduction: The role of central place narratives}

"A powerful narrative reconstructs common sense to make the contingent seem determined and the artificial seem natural."

-William Cronon ${ }^{59}$

It is difficult to talk about a place without telling a story. Place narratives order, qualify and contextualize place in space and time. They play with temporalities, grounding the present in a past, or imagined futures. Projections or predictions are baked into the rational act of investment and often rely on assumptions that are both narrative and normative, i.e. "everyone wants a home, therefore buying a house is a good investment". However, it's important to distinguish place narratives from statements of fact. They may contain data or truths (the most successful ones rely on them), but the order and way in which that information is presented, what it magnifies or excludes, ultimately produces distortion. Narratives, stories and everyday speech acts do a certain kind of work (Austin, 1961). ${ }^{60}$ The "narrative turn" (storytelling, branding and image-making) in planning theory and community planning practice has incorporated the power of this story-telling work for good, as part of pragmatic community planning, to advocate for social justice or capture the lived reality of the marginalized and those without a voice in urban contexts and histories (Forester, 1999;

\footnotetext{
${ }^{59}$ Cronon, W. (1992). A place for stories: Nature, history, and narrative. The Journal of American History, 78(4), 1347.

${ }^{60}$ Austin, J. (1961). Performative Utterances. Philosophical Papers. Oxford: Oxford University Press.
} 
Mandelbaum, 1991; Throgmorton, 2003; van Hulst, 2012). ${ }^{61}$ It takes conscientious and tenacious effort to tell a new story or recuperate histories that are often in competition, or actively suppressed by powerful actors. ${ }^{62}$ The commodification of stories, storytelling labor and place narratives is an important step in the construction of urban housing markets and real estate lobbies. For example, Searle (2016) demonstrates the semiotic work of real estate developers in the making of Gurgaon's housing market. Just as newspapers need good headlines to sell, so do urban imaginaries. When such processes go into overdrive, there is a risk that "fictional urbanism[s]" may begin to "substitute narrative production for real production of cities and territory" (Mager \& Matthey, 2015; Matthey, 2011). ${ }^{63}$ Gurgaon's urbanization had its boosters and their stories and imaginaries of the city. While aspects of the Millennium city narrative have been realized, serving private interests and state revenues, the ways in which it fails to incorporate or account for its shortcomings, in turn, gives power and a sense of absolutist "reality" to the counter narrative of the

\footnotetext{
${ }^{61}$ Forester, J. (1999). The deliberative practitioner: Encouraging participatory planning processes. Cambridge, MA: MIT Press.

Mandelbaum, S. (1991). Telling Stories. Journal of Planning Education and Research. 10: 209-214.

Throgmorton, J. A. (2003). Planning as persuasive storytelling in the context of 'the network society'. Planning Theory. 2(2), 125-151.

van Hulst, M. (2012). Storytelling, a model of and a model for planning. Planning Theory, 11(3), 299-318.

62 The recasting of these relationships evolved with the project of subaltern studies in the 1980s, which challenged the idea that the Global South can be studied or known without invoking colonial relationships and structures of power. Critiques that took up the historiography of the postcolonial and post imperial world focused on South Asia, and the Gramscian (1971) category of the subaltern. Gramsci, A. (1971). Selections from the Prison Notebooks. London: Lawrence and Wishart.

${ }^{63}$ Mager, C. and Matthey, L. (2015). Tales of the City. Storytelling as a contemporary tool of urban planning and design. Journal of Urban Research.

Matthey L. (2011). Urbanisme fictionnel: l'action urbaine à l'heure de la société du spectacle. Métropolitiques.
} 
"bad city," a zero sum game in which different communities must compete for resources and attention in a resource poor environment. Both the millennium city and the bad city obscure other possibilities for emplacement and reinvention among residents and migrants, locals and newcomers, alike. These obscured possibilities include the ability to publicly confront and acknowledge the exclusion of various groups and the material realities of dysfunctional infrastructure, informal settlements, and environmental degradation unfolding on the ground.

This chapter extends Searle's (2016) analysis of how Gurgaon's housing market was built by stories, predictions and projections for a city yet to come, by unpacking the central place narrative of Gurgaon in a broader historical and conceptual frame. The narrative of the millennium city was powerful in part because it painted an image consistent with a broader national narrative of "rising India" (Searle, 2016). However, the hero arc of the city required preceding stories of place in order to work. Like the city's namesake teacher, the protagonists of the millennium city narrative had to manufacture an outcome at the expense of other possible protagonists. Urban prosperity had to be contrasted with an antagonist, a particular landscape idea, in this case, rural Haryana before industrialization and urbanization, or the "wasteland". ${ }^{64}$ The idea of a wasteland has varied and even poetic meanings (Gandy, 2013). ${ }^{65}$ In US urban planning parlance, there is the less romantic brownfield

\footnotetext{
${ }^{64}$ One could apply the idea of terra nullius, or no man's land, a legal argument, method, and mindset used by European colonizers in the Americas, Africa and Australia to justify the seizure of lands held under indigenous tenure arrangements that did not register within the colonizer's established frameworks of land ownership. Kedar, A., Amara, A., \& Yiftachel, O. (2018). Emptied lands: a legal geography of Bedouin rights in the Negev. Stanford, California: Stanford University Press.

${ }^{65}$ Gandy, M. (2013). Marginalia: Aesthetics, Ecology, and Urban Wastelands. Annals of the
} 
designation for sites that have been so environmentally contaminated by human activities, they can no longer be used for other purposes without rehabilitation. In Indian land-use classification, there are lands which are technically unavailable for agricultural production, under fallow, also referred to as "cultivable wasteland" or banjar. Such lands may have high salinity levels or waterlogging, but their classification rarely hints at irreversible contamination. The wasteland is more imaginary than literal category in this case, and the categories themselves often appear subjective or open to interpretation. The idea that Gurgaon's urbanization was the rehabilitation of a kind of wasteland, ${ }^{66}$ has been used at different moments for different audiences. There are elements of truth to this narrative. When Haryana was cut out of the Punjab in the 1960s, its boundaries did not contain a major river system. It had the lowest rate of forest cover of any Indian state. Gurgaon District's soils had high salinity levels and were difficult to irrigate. For these reasons, it was easy for real estate developers to convince politicians to grant licenses and land use conversions, as well as persuade local farmers to part with their ancestral homes and buy elsewhere.

This narrative obscures the ways in which the district's fragile ecology gradually arrived at this condition, assisted by human intervention, including deforestation and canal building during the Mughal and colonial periods. At one time a floodplain, Gurgaon formed a subtle depression in the landscape that collected water and held it for months, enabling a seasonal wetland. Colonial-era hydro-infrastructures

Association of American Geographers, 103(6), 1301-1316.

${ }^{66}$ The term "brownfield" does not exist in Indian planning lingo. The technical land use classification that most closely aligns with this in India is cultivable wasteland. But even this does not have the explicit connotation of environmental degradation. 
starved the region of river flood waters from the Yamuna. As the district dried, poverty worsened among its largely subsistence communities, who found employment as soldiers, militiamen, shepherds, and laborers. These communities were encouraged to clear forests and grow crops to boost colonial tax revenues (Oldenburg, 2018). Even in the post-partition era, Gurgaon District was seen as a poor candidate for agricultural investment and passed over for Green Revolution projects in the 1960s (Gururani, 2013). ${ }^{67}$ The characterization of Gurgaon as inherently resource poor or wasted has also justified the flagrant exploitation of ground-water and other resources in the present day, pushing the city's water table to its dregs, under the logic that the underproductive land had little ecological value worth conserving once it was no longer classified as farmland (Vij \& Narain, 2016). ${ }^{68}$

The irony of the wasteland is that its antinomy, the garden city (greenfield as opposed to brownfield) was initially used to lure middle-class buyers. While developers and politicians might have looked on the arid plains as irretrievably barren, there was something of an ecological savior narrative in the way housing was marketed to a certain subset of the conscientious middle-class, who saw a space in which they could start over and build a garden in the wilderness. That both the wasteland and the garden city could co-exist or play off one another while serving their audiences confirms Gandy's (2013) observation that the "brown-green antinomy"

${ }^{67}$ Gururani, S. (2013). Flexible Planning: The Making of India's Millennium City, Gurgaon. In Ecologies of Urbanism in India: Metropolitan Civility and Sustainability. Hong Kong: Hong Kong University Press.

${ }^{68} \mathrm{Vij}$, S. and Narain, V. (2016). Land, water \& power: the demise of common property resources in peri-urban Gurgaon, India. Land Use Policy, 50, 59-66. 
in urban ecology is a social construct with deep interference from urban land markets and planning histories.

Since the colonial period, Gurgaon had developed a reputation for being ecologically barren and infertile, but also culturally. The idea of Haryana's farmers as poor stewards of their own land seemed to appear even within progressive conversations about restoring the district's indigenous plant-life and ecosystems services (Baviskar, 2018). This view also extended to Haryana's political culture, which has a reputation for corruption and rebellion.

K.P. Singh (2011), the man behind DLF's real estate ventures in Gurgaon, described Haryana as a progressive state. Yet a former Speaker of the Haryana State Assembly once remarked "if one stuck a spade in the Arab countries one struck oil; if one stuck a spade in Haryana, corruption oozed out” (Mankekar \& Mankekar, 1977).

In his account of fieldwork in a small village in North India, Gupta (2012) asked why it is that narratives of corruption have such a hold on the social imagination. "I heard stories about corruption more often than almost any other genre of folklore." He notes that such stories "sometimes employ idioms and analogies from Hindu religious epics. After all, corruption narratives are steeped in many of the qualities of epic stories: heroism, debasement, the fall of humans from the path of virtue, resoluteness, the overcoming of impossible odds and the making of superhuman sacrifices, and providential actions of an unknown deity, which could be anyone from the chief minister to the district magistrate.” In 2016, Gurgaon was renamed Gurugram (teacher village), a nod to the Sanskrit epic, the Mahabharata. The original teacher village was supposedly a gift from the princes at the center of the epic, 
given to their archery teacher Guru Dronacharya. We are reminded of this at the first stop in Gurgaon along Delhi's metro, the eponymous Guru Dronacharya station. The renaming of Gurgaon appears to be, if not a stab at rebranding the city, then a modest attempt to appease the cultural critics in search of heritage ties. The irony of this, Oldenburg (2016) points out, is the way in which Gurgaon's namesake pulled a similar maneuver. Dronacharya "behaves unscrupulously in the Mahabharata. He is the man who extracted the right thumb as gurudakshina ${ }^{69}$ from the lad he declined to teach for being what we would call a Scheduled Tribe in current parlance, to promote his own protégé to the top position in archery in a beleaguered kingdom. Dronacharya was perhaps an unsurpassed example of what a guru should not be." ${ }^{70}$ In some ways, the story is the perfect allegory for the worst episodes of clientelism and corruption in favor of elite interests in the city's history. It also illustrates how a story of heroism and success may hide casualties or better possibilities that were squashed along the way, "[making] the contingent seem determined and the artificial seem natural" (Cronon, 1992).

Gurgaon's mythic origins, and the unintended negative associations of an unscrupulous teacher, are prescient of the corruption narrative and allegations surrounding the city's first major economic development and urbanization projects. Stories of corruption, whether glossed over, ignored or instrumentalized, also figure as

${ }^{69}$ Payment or gift given to a teacher after completion of studies.

${ }^{70}$ Oldenburg, V. (April 15, 2016). City that Grew at Night: Renaming Gurgaon as Gurugram Indicates Rustic Imagination of Millennium City's Political Masters. Times of India. Retrieved from: http://blogs.timesofindia.indiatimes.com/toi-edit-page/city-that-grew-at-night-renamingas-gurugram-indicates-rustic-imagination-of-millennium-citys-political-masters/ 
plot devices in Gurgaon's central place narrative in different ways. The millennium city brand invokes a particular moment in time and relies on an instant city temporality: Gurgaon came up overnight as a result of liberalization, and the opening up of its economy to foreign direct investment. ${ }^{71}$ While the bulk of Gurgaon's development did occur after 1991, the District began to urbanize long before that. Industrial development was a local endeavor, based on the deal between the Chief Minister Bansi Lal, and the Gandhis, beginning in the 1960-70s. The instant city narrative downplays this earlier, less successful story of state-led industrial development and urbanization, while highlighting the heavy hand and corruption of state-based development projects (ultimately rescued by a foreign firm, Japanese Suzuki).

With these two pieces in place, the wasteland and its backward inhabitants, and the corruption or inefficacy of state-led planning, the story of progress, cultural convergence, of globalization and capitalism itself, can begin. The private city becomes a Deus ex Machina, both the object and the means of execution for a better urban future. The logics of this story, of course, rest on facile binaries of city and nature, or require us to ignore how deeply imbricated state and private actors may be. Furthermore, the "urban solution" to the agrarian water scarcity problem (that was used to convince farmers to sell), conveniently ignores the fact that the construction of and provision for a city of many millions would probably be more water intensive than growing millet. The notion that this happened within a vacuum of state-led planning,

71 Stories of corruption have salience in Northern India, and reinforce low expectations of the state (Gupta, 2012). 
in which the private sector and the wise hand of the market were given free reign, is also patently untrue. This market, as Searle (2016) meticulously documents, has been largely speculative, and while shaped by international financial institutions and norms, presents its own cultural confluence of local and place-based practices and institutions that shape the way in which businesses can operate and plans become executed. The partnership between Haryana state government and developers, like the Delhi Land and Finance Corporation (DLF), was never a smooth one. Originally helmed by KP Singh, DLF was one of the major progenitors of the Millennium City brand, assembling an unprecedented 3,500 acres initially in Gurgaon for group housing ventures from the 1980s onward. While Singh and others finally gained allies in government, and could promote major land reforms, this work would take decades of negotiation and relationship building to accomplish. The vision behind this brand, and the tactics made explicit by the company's charismatic Executive reveal how the millennium city narrative was built, and then operationalized, to fundamentally alter the landed economy and social relationships to place.

\section{The Gurgaon Experiment}

The city of Gurgaon has a long history of not having a history. According to Oldenburg (2018) "Gurgaon is remarkable only for being unremarkable...During the Flourishing times of the Mughal Empire Gurgaon may be said to have no history."72 This could be said of Haryana itself, which has often figured in the past few centuries as the backyard for the drama unfolding in Delhi, or as a corridor for invasions from

\footnotetext{
${ }^{72}$ Oldenburg (2018) quoting the Punjab District Gazetteer, Vol IVA, 1910, p 19.
} 
the Northwest. The District of Gurgaon was composed of villages for generations, spread across arid, alluvial plains, skirted by the Aravalli hills, just $30 \mathrm{~km}$ southwest of Delhi. The region itself was once the breadbasket of Northern India, before tectonic shifts in the Himalayas diminished the Indus and Yamuna rivers, and the Ganga became the dominant river system (Jain \& Dandona, 2012). Census literature and state websites begin telling Gurgaon's history with the Mahabharata epic and progress to the Mauryan and Harsha Empires. They describe how the District participated in the founding of Delhi and fared under Muslim invaders. Held under Afghan and Mughal rule into the 16th century, a rebel prince and challenger to Akbar from Rewari, put the district on the map, but was soundly defeated. Gurgaon was subdivided under the Marathas in the 18th century, and among various rulers, divided into parangas or administrative subunits and eventually handed to British control in 1803 (ibid). According to British accounts, the region was "indeed idyllic: its jhils, small lakes, gushing seasonal torrents, and vast central wetlands that supported spectacular bird life, deer, antelopes, and even cheetahs and leopards" (Oldenburg, 2018).

When the British became interested in Gurgaon, it was then part of the Punjab, on the doorstep of Delhi, which would not become the center of British control in India until 1911. Villagers grew millet, mustard, vegetables, and wheat, though the latter did not thrive (Brayne, 1929). The largest groups were the Jats, who raised cattle, grew crops, supplied soldiers, cleared forests and built canals for the British, fought in the East India Company, and were given land in return for clearing the region of forest, and for service in the company regiment, which Oldenburg (2018) argues reinforced the desire for male children. She remarks "Gurgaonwallas were 
chiefly cannon fodder...Gurgaon lived, as it were, in the churn." By the early 19th century, the British had established a small administrative town, Gurgaon Station, in the district and marked out 5 tehsils, containing what Oldenburg refers to as the $5 \mathrm{Cs}$, the cantonment, the civil lines, the church, the court, and the collectorate. Locals were enlisted to clear land, sell the fodder and become revenue sharecroppers. In order to achieve this, the British privatized land ownership for revenue collection, using a system that relied on the size of land parcels rather than a percentage of harvests. As Oldenburg (2018) writes "It altered the essential meaning of land, from an asset that was controlled by and its produce shared among joint cultivators to the English idea of land as a commodity with a single, registered owner."

While the region had low rainfall, during the monsoons the Yamuna (along the Eastern side of Delhi) would flood. The British built bunds and canals, including the Yamuna canal in 1841 and the Agra canal in 1874, to capture the water. These infrastructures ultimately dried Gurgaon's wetlands. Lakes shrank to ponds, and soon mosquitoes bred in the shallow water and thousands died in breakouts of malaria and dengue. The canals also raised the salinity of the soil, making large swaths of land uncultivable (Oldenburg, 2018).

In the 1920s, an Indian Civil Service Officer, Lord Frank Lugard Brayne, was posted to the Punjab as head of Gurgaon District's reconstruction. His project began as a fault-finding mission. But Brayne, the son of a reformer in Africa, adopted a selfhelp approach and made it his personal mission to study rural Gurgaon's peasantry (more than half a million villagers), then struggling with poverty, low agricultural yields, and disease. Brayne wrote several volumes about the District describing "the 
moving tale of the difficulties which clouded the lives of the rural population in the Gurgaon District, and of the methods by which Mr. and Mrs. Brayne and their devoted fellow-workers strove to overcome the inertia of centuries and to bring a little light to thousands of humble homes."73

He called his plan the "Gurgaon scheme of uplift" intended "for the use of lecturers, schoolmasters, social workers, and all those, officials or non-officials, who are endeavouring to better the con-ditions of the people of Gurgaon District and to improve their conditions of life."

In his effort to uplift the villagers of Gurgaon District Brayne spelled out the problems with Haryanvi and Gurgaonian villagers in condescending terms:

"Every villager prays for: 1 . Good crops. 2 . Healthy children. Why doesn't he get them? Because: 1 . His methods of farming are bad. 2. His village is filthy; he lives in dirt, squalor, disease and suffering. 3. He is the prey of epidemic diseases. 4 . He wastes all his wealth. 5. He keeps his womenfolk in degradation and slavery. 6 . He pays no attention to his home or his village and spends no time or thought over bettering himself and his surroundings. 7 . He resists all change; he is illiterate and ignorant of what progress village folk in other civilized countries and in other parts of his own country are making, and what he can himself make if he sets his mind to it."

He emphasized behavior and attitudinal change, discarding long standing practices in favor of village improvement projects: money in the bank, women in the garden, waste in a latrine, and men in the field ploughing their own fields, cleaning their own villages, and plenty of light and fresh air and flower beds. He castigated villagers for using their cattle manure as dung-cakes for fuel instead of fertilizer, buying jewelry instead of putting money in banks: "Everyone should be a member of

\footnotetext{
${ }^{73}$ Brayne, F.L. (1929). The remaking of Village India. Oxford: Oxford University Press. retrieved from: https://archive.org/stream/remakingofvillag031139mbp/remakingofvillag031139mbp_djvu.txt
} 
at least one bank. It is stupid not to be." He encouraged farmers to grow fruit trees. He complained often of the yellow-tailed moth. While he thanked the many thousands of villagers who helped him gather his information, he was repetitious in his cultural critiques:

"The only thing a zamindar kills is his own brother...Monkeys, rats, snakes, kutra and everything may come into his fields with impunity and eat them up, but if his brother zamindar lets his cattle come in, woe betide him"

Brayne's account serves as a perfect example of the ways in which the land and the people themselves, became one and the same in the cultural imagination of the colonizers. As Brayne preached improved farming and sanitation practices, he came up against a set of environmental conditions that his beneficiaries were still struggling to understand and adapt to. Rather than understand their struggles as contingent on recent history, Brayne seemed to view villager life as a fixed, long-standing, taxonomic object, an aberrant form of nature that had to be guided and corrected. Through this view, what seemed like maladaptation and lack of knowledge about a changing environment was not a problem created or exacerbated by colonial occupation but presented further justification for it. For many decades to come, and even after independence, Gurgaon functioned as the watering hole and vegetable market on the way to Jaipur. It wasn't until Haryana achieved statehood that serious interest in developing the district was revived.

\section{The Architect of Modern Haryana}

Nearly 40 years before it would have an elected Mayor, Haryana's first and longest serving Chief Minister, Bansi Lal, facilitated a project, on behalf of Sanjay 
Gandhi, to build a factory for India's first "indigenous" car. This episode details the political and planning maneuvers that enabled Gurgaon's first major land use conversion in the early 1970s. While there was a friendship at the center of that deal, its history is generally told as one of corruption and abuse of power. Lal took office only a few years after Haryana became an official state and came to be known as "the Architect of Modern Haryana", despite his adversarial and contested leadership. Lal benefited from close ties to Sanjay and Indira Gandhi. But apart from his steadfast loyalty to the Gandhi family, Lal had a reputation for turning on people.

He began his political career as a district lawyer, and acted as the polling agent for Minister Chandravati, who later denounced and defeated him in a 1977 election. In the early 1960s, Lal secured a Congress ticket for the Haryana State Assembly, where he became a loyalist to the acting Chief Minister, Bhagwat Dayal Sharma. In 1967, when Sharma faced trouble, however, Lal quietly withdrew, failing to attend the session in which the Chief Minister's opposition attempted to topple his leadership (Mankekar \& Mankekar, 1977).

Whereas Lal's political allegiances were subject to revision, he managed to win the support of the public. He was initially admired by Jat farmers for his direct style of governing. ${ }^{74}$ At the time, Haryana was struggling as a rural backwater, and Lal was credited for turning deficits to surpluses, for introducing irrigation canals and access to fertilizers. Faridabad township, near Delhi, became a major industrial center under Lal. He pushed industrialization projects, the construction of roads and

\footnotetext{
${ }^{74}$ Jats are an historically agricultural community and one of the dominant sub-caste groups in Gurgaon District and Northern India. In many states, they are now considered an OBC (Other Backward Class).
} 
electricity lines to villages, despite claims of corruption within the state electricity board. He was also known for his authoritarianism, nepotism, and extreme dislike of the press. Lal was rumored to have held grudges that spanned decades. He sought retribution in the form of lawsuits, harassment, and public humiliation, but the most serious allegations come from Lal's involvement during the Emergency Period, under Indira Gandhi. It was through Sanjay Gandhi's reshuffling of the cabinet, that the existing Defense Minister, Sharma Singh, was removed and replaced by Lal in 1975 (Mankekar \& Mankekar, 1977, p. 141).

Violence escalated in Haryana during that period as thousands of village men were forced to comply with Sanjay's family planning program, vigorously implemented by Lal. The irony of these events, according to Gupta (2012), was that "the Emergency was justified by the need to crack down on widespread corruption" (p. 112). Though he eventually apologized to the state of Haryana for his participation in the sterilization programs, Lal's actions led to his and the Ruling Party's eventual defeat (Tarlo, 2003). ${ }^{75}$

\section{Maruti, Son of the Wind God}

Early in his tenure as Chief Minister, Lal facilitated a controversial deal with the Gandhis, the first major land conversion of Gurgaon's urbanization. The backdrop to this was a project set up by the Central Government in 1959. A committee had been established under the Secretary of the Ministry of Commerce and Industry to consider

\footnotetext{
75 Tarlo, E. (2001). Unsettling Memories: Narratives of the Emergency in Delhi. Berkeley: University of California Press.
} 
the possibility of producing an indigenous car. Preference would be given to government-based (rather than private) proposals for a car with parts manufactured entirely in India. There had been some proposals to expand existing manufacturers, but there wasn't enough demand to justify moving forward with them.

In 1964, Sanjay Gandhi went to England to study engineering and complete an apprenticeship with Rolls Royce Motors. The country was under the leadership of his mother, Indira Gandhi, when Sanjay returned to India in 1968. The 22-year-old applied for a license under the Industries Development and Regulation Act of 1951 to launch Maruti Ltd. In nod to indigeneity, the company was named for another character in the Mahabharata, also a central character in the Ramayana, the son of the Hindu God of winds. As part of his application, Gandhi submitted evidence from the head of Rolls Royce Motors that he had been a special apprentice there for three years, where he had attended a technical college part-time, and received a National Certificate of Mechanical Engineering. He left a year shy of completing the apprenticeship, but this did not seem to be a hindrance. Gandhi was already attempting to build a prototype of the car in a shack in the Gulabi Bagh area of Delhi (Gupta, 1979). 


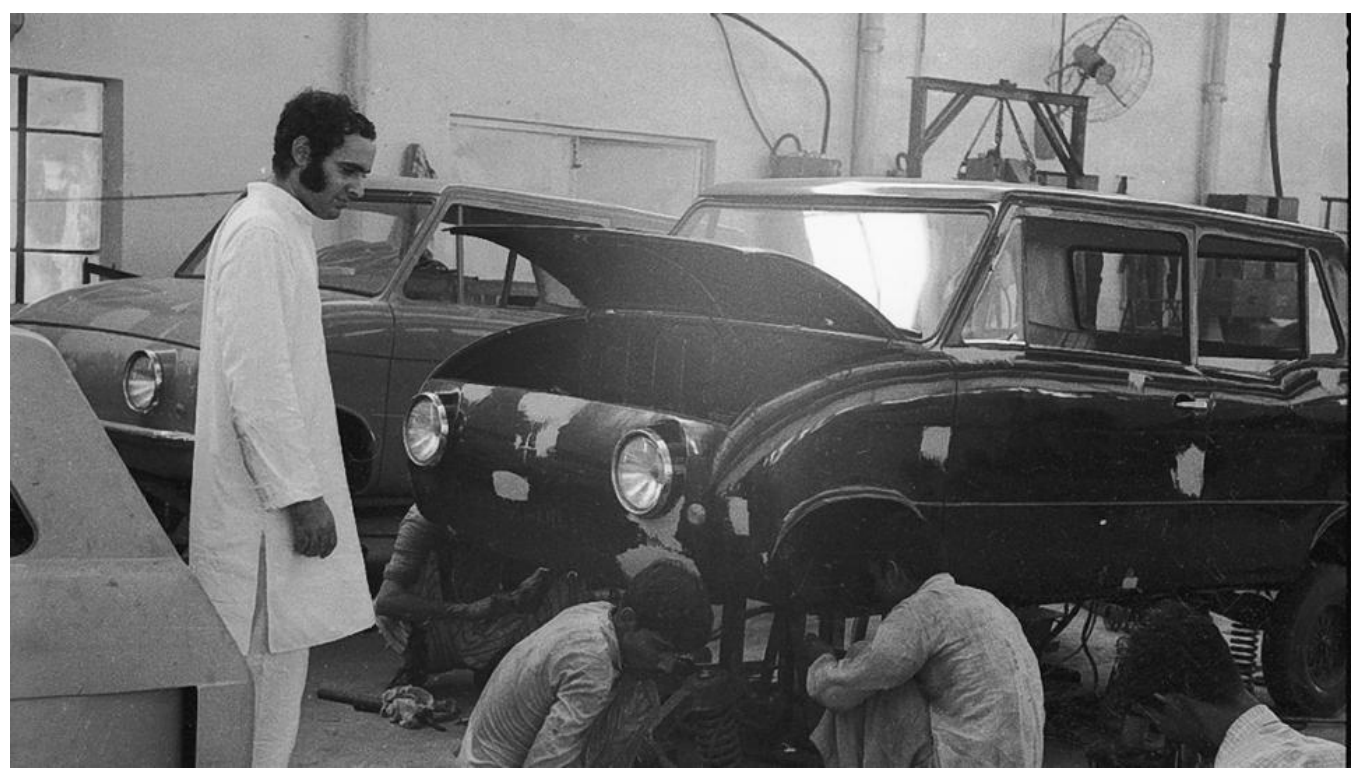

Figure 2: Sanjay Gandhi on the Maruti floor, Gurgaon, Sept 1973. Hindustan Times Archive.

A week after Gandhi submitted his application for a license, Lal had written to the Chief Union Minister of Industrial Development and Company Affairs, persuading him to allow Gandhi to go ahead, despite reservations about the project's feasibility. Within a week of the application's submission, Lal had set about selecting a site for it. Haryana was prepared to offer services and financing, with a suggested location at Faridabad, but Gandhi requested to switch the location of the factory to Gurgaon District (Gupta, 1979, p. 26). While the company licensing and other aspects suggested preferential treatment, it was the acquisition of the land on which Gandhi's factory could be built that caused demonstrable conflict within the planning bureaucracy and for the people who inhabited rural Gurgaon.

Gandhi had visited some sites near Sonipat, escorted by the Secretary to the Chief Minister and the Director of Town and Country Planning, but preferred something on or near Mehrauli-Gurgaon (MG) road in the revenue estate of Dundahera. Without making a formal application, Gandhi requested roughly 300 
acres. While 291 of those acres were privately held, approximately 157 belonged to the Defense Department. The Deputy Commissioner of Gurgaon had suggested in a letter that perhaps these acres could be "released" with some persuasion (Gupta, 1979, p. 26).

The legal strategy for acquiring the rest of the land, however, involved using section 4 of the Land Acquisition Act, and section 17, which states "In cases of urgency, the Collector...may take possession of any land needed for a public purpose. Such land shall thereupon vest absolutely in the Government, free from all encumbrances."76

In addition to the legal obstacles to ownership, the land was also subject to the Punjab Scheduled Roads and Controlled Areas Restriction of Unregulated Development Act of 1963, which had been extended to Haryana "to prevent haphazard and sub-standard development along scheduled roads and in controlled areas" (Gupta, 1979, p. 27). This prohibited construction within 30 meters of a scheduled road, which would have made building in the areas Gandhi had selected illegal.

While Gurgaon District's planners in the Department of Town and Country Planning adhered to a prescribed process for drafting plans, eventually making notifications to the public for objections before approval, Gandhi seemed to have circumvented this process. Concerns arose about the suitability of the site, and planners proposed converting the land from a rural designation to industrial use in the draft plans.

${ }^{76}$ Land Acquisition Act 1894, Section 17, Special Powers in Case of Urgency. 
Gandhi's project remained in the pipeline for several years with no movement until November 1970 when the request to obtain the 157 acres from the Defense Department was formally submitted. A new development plan was drafted in 1971, converting the land from rural to industrial use. The Defense Department would not release the land Gandhi requested, but a final allotment of 444.5 acres was granted (Gupta, 1979, p. 28).

At this stage in the project's development, the rural inhabitants of the villages slated for industrial conversion and acquisition brought forward a writ petition in the Punjab and Haryana High Court, challenging the use of the urgency provision of the Land Acquisition Act. The section used to justify the land grab was an eminent domain clause, designed to allow the government to seize private land for the public good. The petitioners demanded to know the nature of the "urgency" in this conversion, which would force the sale of their lands. On legal advice, the planners skirted these objections by publishing a new notification without mention of section 17, making the writ petition arguments moot (Gupta, 1979, p. 29).

In addition to accommodating the project's land use changes, the government extended itself further where there were budgetary concerns. The Town and Country Planning Department would bear the cost of obtaining the land and would lease it to Gandhi. However, the Urban Estates Department had no provisions for the acquisition. The project became further embroiled in challenges within government, as various ministers and agencies wanted to understand why Gandhi required such a large plot of land, what the justification would be, the electricity requirements and other details that were left vague or absent in the proposals. The Industries Minister, L.C. Gupta, 
believed "there was no moral or other justification for dispossessing the tillers of the land." Under deposition Gupta stated, "this was treated as a special case...and at each and every stage the Chief Minister had to be fully kept in the picture" (Gupta, 1979, p. $30)$.

Draft plans were further amended when Gandhi noted residential sectors abutting the industrial area. "He did not like the idea of a residential sector (housing laborers) to be located in the midst of an industrial area as it might lead to increased labour trouble," and a new plan was drafted with a larger industrially zoned area (Gupta, 1979, p. 30).

Once plans were finalized and approved, a Land Acquisition Collector (LAC) was sent to inspect before approving the transaction and handing over possession. The LAC made his report for the 444.5 acres, spread across five of Gurgaon's villages and released a series of objections, observing that 1.) the land was fertile, and was contributing to food production, 2.) small landowners would be losing their means of subsistence and livelihood. 3.) the sales probably wouldn't return on investment. 4.) there were less fertile lands available nearby that could have been acquired 5.) the location was near an ammunition depot/air force installment, which needed a safety area of 1000 yards. In total there were 1086 concerned parties dependent on the land for agricultural livelihoods (Gupta, 1979, p. 31).

It was already the summer of 1971, and Lal was under heat from Gandhi to speed up the process. The LAC's objections were ignored. Within a matter of weeks, notices were served to the owners/occupants. The Finance Commissioner wanted payment upfront for the land at roughly 12,000 Rs per acre, but Lal pushed for a lower 
price than the cost of acquisition. Payment was decided at $10 \%$ down payment plus 18 installments over a two-year period at 7\% interest, plus no sales tax for a period of five years on raw goods and materials. According to the Industry Minister, Gupta "there was no such instance of any other unit in Haryana where concessions on this scale were provided and the decision in this regard was also taken by the Chief Minister" (Gupta, 1979, p. 34).

On the date of the acquisition and transfer, the LAC received 191 claims across four villages, Mullahera, Dundahera, Sarhaul, and Shapur. The claims were heard in a space of a morning, with 35 checks cut by the evening. The land was acquired for a little less than 5 million Rs. total. This was paid for out of the Urban Estate Department's budget, despite the lack of initial provision. Gandhi signed the agreement and the land was transferred to Maruti (Gupta, 1979, p. 35).

From the outset of the project and initial breaking ground, Maruti faced financial and legal challenges. Forms were taken late on the construction of factory buildings. The company regularly ignored or violated rules and regulations and building height restrictions. Service roads were built without government approval or with the tacit assumption that there would be approval. A building inspector once found various violations of the Indian Works of Defense Act which prohibited the construction of buildings within 1000 yards of an ammunition depot or air force installation. The rationale for the law is not difficult to imagine. The inspector issued an order to cease construction, followed by a demolition notice, which was ignored (Gupta, 1979, p. 38). 
Maruti eventually went into liquidation in 1977 and the government looked for a way to resuscitate it by welcoming a foreign subsidiary. The problems with the initial Maruti project proposal, alongside the violation of various codes and laws during the construction of the factory, provide further evidence that the project was selected not because of its merits, but to secure the favor of those in central government. Planning authorities acted as gatekeepers, interpreting the law through physical planning. In the case of the Maruti deal, those checks and balances were circumvented, ignored or altered to suit the exception.

In 1979, a commission was formed to investigate the Maruti deal with 111 public sittings, and 268 witnesses. The Central Government's aim was to conclude what preference, if any, was shown to the Maruti car project and the justification, if this was the case. ${ }^{77}$ The published Inquiry into the Maruti affair traces a timeline of events that show Lal's motivations, and the corruption narrative at the center of the Maruti chapter in Gurgaon's history, to be more complicated than favoritism alone.

In 1968, the year Sanjay Gandhi returned from England, Lal had just become Haryana's Chief Minister and was already causing unrest within his party. Ministers in his cabinet had written to the President of the All India Congress committee about his leadership. Several months later, seventeen members of the Haryana Legislative Assembly withdrew support for Lal. Within a week, Gandhi had applied for the Maruti License. Lal sent a request to the Union Minister of Industrial Development and

\footnotetext{
${ }^{77}$ A separate inquiry was conducted in 1977 under Justice P. Jaganmohan Reddy to investigate Bansi Lal's transactions as Chief Minister of Haryana.
} 
Company Affairs but granted permission without his consideration (Gupta, 1979, p. $50)$.

By May of 1969, Lal had racked up 66 misconduct allegations in Parliament. Within the following year, however, Indira Gandhi took over the Ministry of Home Affairs and the Department of Personnel, the departments charged with investigating and taking comments on Lal's allegations. Examination of the evidence began as Sanjay Gandhi was looking for a suitable site in Gurgaon for the Maruti project. Within a month, a letter of intent was issued for Maruti. Two months later, the Union Home Secretary all but threw out the allegations against Lal (Gupta, 1979, p. 50). As Indira Gandhi considered the remaining allegations and evidence against Lal, he meanwhile assured Sanjay Gandhi that he could take possession of the land in Gurgaon. Maruti was incorporated in June 1971. Gandhi took possession, but a set of 14 allegations against Lal remained. In a speech to the Lok Sabha in December 1972, S.N. Mishra said:

"But one thing is abundantly clear, it is almost conclusively proved that the Chief Minister of Haryana has left nothing undone to place the Prime Minister in a situation of blackmail. He has robbed peasants to put her in the wrong...He has tried to equate public interest with private interest. And also tried to say to the world that industrial estate means personal estate" (Gupta, 1979, p. 51).

Setting aside the blackmail allegations, the Maruti Inquiry speculated that the way in which the legal aspects of the acquisition took place displayed a lack of understanding for the public servant's role in facilitating planning. Forms, documents and plans were formalities. What they constituted on the ground, for those displaced or otherwise affected by the project, were never considered. In his concluding notes, A.C. 
Gupta, sitting Supreme Court Judge and author, wondered aloud why so many

officials were complicit in the operation or listened to Lal's instructions.

"No evidence has been found that any kind of inducement was held out to them...In their case it may have only a hope that in future...the services rendered by them would be remembered. It may have been power-worship which blurs judgment and makes one believe that the present trends will continue and whoever is in power at the moment is invincible. They could not enforce the laws against those who appeared to be the laws' masters" (Gupta, 1979, p. 141).

For those who knew Lal's reputation and capacity to disrupt the lives of those who crossed him, the acquiescence of appointed bureaucrats to the Chief Minister makes sense. The unfortunate outcome of Lal's choices was to solidify the idea that Haryana's political culture was particularly vulnerable to corruption, manipulation or inducement. K.P. Singh would describe these politics as "progressive" or "openminded". While a story of failed state planning and corruption might raise cynicism in the eyes of the public, it was this very perception that lured builders like DLF's K.P. Singh over the border from Delhi into a system they eventually realized they could manipulate but not control.

\section{Building the Millennium City}

"In my dreams, night or day, I was already picturing a city with well-planned residential colonies... My father-in-law had built colonies in an existing city; I would complement his efforts by building a city!" (Singh, 2011, p. 184)

The construction of the millennium city's brand overlaps with the selfbranding of the city's boosters. After the failed Maruti project, the next major contender to narrative building in Gurgaon was DLF. Though not alone, the company managed to carve out a significant and catalytic share in the creation of a brand and a 
market for corporate and residential real estate. Kushal Pal (K.P.) Singh, the man who took over and revamped the DLF in the early 1970s, was also a good storyteller. He sees his life unfolding in epic stints of fate, hard work and gumption: "whatever the odds." The autobiography of that name begins "I have cheated death on five occasions." Although Singh's story is not one of rags to riches, he casts himself as rising from "the rural backwaters of Uttar Pradesh to being chauffeured around in a Rolls-Royce." He faced the temptations of the West, "rubbed shoulders with English high society and almost married into it, but fate intervened and sent [him] back to India." After a brief military stint, Singh was "thrown into the world of business without any management background" to take over a company that "hovered on the edge of bankruptcy." He has "faced personal tragedy and been the target of a powerful politician's ire" (p.1). The powerful politician was Bansi Lal. Of his paradoxically elite and everyman position: "I have shared a meal with impoverished farmers by day" (urban villagers) "and been in the company of the cream of Indian society by night" (middle- and upper-class Indians and politicians). He proudly describes his experiences with Florida golf courses and gated communities. Singh (2011) asserts "Whatever fate may have in store, in the end, you have to write your own destiny. Mine was written in a township, later a boom city called Gurgaon” (p. 5). In acknowledging the city's shortcomings Singh says, "despite its infrastructural drawbacks, it is the most modern-looking city in India with its glittering malls, gated condominiums, neatly divided sectors, contemporary skyscrapers, housing some of the world's best-known multinational corporations, and exciting nightlife." The way Singh recounts his role in Gurgaon's urbanization is that of an 
urban visionary with a radical idea no one had ever considered: "Reactions ranged from ridicule to concern for my sanity" (p. 95).

"I just could not stop myself from driving down to the outskirts of Delhi and staring for long hours at the wide-open space all around with nothing but miles and miles of rocky but austerely beautiful landscape. In my mind's eye, I could see tall buildings made of glass and steel. I could visualize wide, tree-lined avenues with smooth moving traffic and people walking on them and children playing in lush green parks."

Singh was not shy about touting the inspiration for this vision in the arid Haryana plains. "Whenever, I went abroad, I made it a point to visit residential areas that were being developed to get ideas. On one such visit to Florida, I saw scores of residential areas where both the low- and high-rise buildings coexisted, built around sprawling green spaces generally in the form of golf courses." In India, Singh (2011) observed, most residential colonies were single-density, but "the Florida-type developments were all a mix of such housing. The idea of creating something like that in India kept me up at night” (p. 200).

He also touted his connections to people in high places and the serendipity of his first encounter with Rajiv Gandhi, the future Prime Minister, having car trouble on a dusty road in Haryana. "We sat there for an hour and a half, in the middle of nowhere, engaged in detailed discussions about the idea of creating an integrated, world-class township in Gurgaon. That day I realized this young politician could be an agent of change" (Singh, 2011, p. 7). Singh was trying to personally acquire shares in the company to get out of the battery manufacturing industry and relaunch DLF as a major real estate developer in Gurgaon. He describes Gandhi as "instrumental in ushering the private sector back into urban development. Those reforms would 
revolutionize the real estate sector and also allow DLF to expand at a scorching pace" (ibid).

Singh had entered DLF as the son-in-law of founder Chaudhary Raghvendra Singh. C.R. Singh saw the potential for Delhi's post-partition population boom, and launched DLF in 1946, a year before independence. Taking personal loans from friends and business associates, he bought up vast tracts of land, eventually developing 21 colonies in Delhi after independence (DLF, 2017). These colonies were built in collaboration with government planners, typically composed of two to four story homes, laid out in gridded patterns with central markets (Hull, 2011; Sundaram, 2011).

Under the vision of Nehru, however, companies with large land-holdings, such as DLF, threatened a vision of state-sponsored urban planning. In 1955, the recommendations of the Birla Committee led to the Delhi Development Act and the establishment of the Delhi Development Authority (DDA). The DDA replaced the British colonial Delhi Improvement Trust (DIT), although it maintained many of the norms and procedural aspects of planning from the previous agency (Sundaram, 2011; Legg, 2007).

Of Nehru's governance in urban planning, K. P. Singh says, "his intentions were noble but the inevitable happened due to the inability of the DDA to cope with the demand for urban land and housing. Unauthorized construction erupted and fly-bynight developers started looking for loopholes...In 1960, in one sweeping move, an illconceived government order banned the development of urban land by the private sector" (Singh, 2011, p 73-74). DLF had been at work on Greater Kailash I, but 
Nehru had been persuaded that the plans would include slum areas, an error that was quickly corrected. However, within the first decades of independence, DLF found itself exiled from the city and shifted to manufacturing.

This turned out to be a benefit for K.P. Singh, whose connections formed in heavy industry in the early days of DLF, bolstered his prospects as a real estate developer in Gurgaon. Singh attributes the entrance of GE and their decision to finally invest in India and build a Genpact plant in Gurgaon on his (and Rajiv Gandhi's) relationship with its CEO, Jack Welch (Singh, 2011, p. 225). One of his earliest business mentors was also George Hoddy of Universal Electric. "Hoddy once told me that it was so tempting to lose sight of ethics as India's archaic laws and bureaucracy made it almost impossible for business to flourish. His solution was not to break or evade laws, but to lobby to change them" (Singh 2011, p. 78).

The idea of lobbying to change the law became instrumental to Singh's strategy in Gurgaon, but he was also sensitive to his father-in-law's missteps in entering politics and stayed out of elected government. "For a business like real estate, it was essential to maintain good relationships with all political parties and not be seen to be aligned with one party. Any active role on my part on behalf of one party, he said, would be suicidal" (Singh, 2011, p. 157).

In the late 1970s, Singh was posted at American Universal in Faridabad. He explains how industrialists were often pressured by local politicians to make donations to political parties (Singh, 2011, p. 82). He recounted one such instance where Chief Minister Bansi Lal mistreated the Chairman of Escorts, a person of influence in his own right, because the American company refused to give political contributions. Lal 
eventually acknowledged Nanda (the Chairman) "I know you are Hari Nanda of Escorts but why have you come alone? Where is your Jimmy Carter? I believe that you cannot do anything in your factory without the permission of your American partner. Unless you bring him along, I cannot meet you" (Singh, 2011, p. 84).

Despite shying away from government office, Singh was elected to leadership positions in business network organizations, such as the PHD Chamber of Commerce, and the Associated Chamber of Commerce of India. "These exposures were invaluable as they helped me press the government on reforms and for regulatory changes necessary for the country's economic growth" (Singh, 2011, p. 117).

Singh frequently ended up in court over DLF holdings, which had made him an attentive student of land use law. He was critical of colonial-era laws, an anachronism of a young democratic country, even though many of the restrictions in Delhi that directly impacted DLF were post-colonial reforms. The Urban Land Ceiling Act of 1976 limited the amount of land any one person or entity could acquire in Delhi, capping at 500 sq. meters. At enactment, DLF faced major losses on individual plots where owners had chosen to pay in installments. Such restrictions also existed in UP, but not in Haryana, which was overseen by the Haryana Urban Development Authority (HUDA). As Singh prepared to get back into real estate, DLF was awarded a large sum in the DDA's acquiring Greater Kailash II, which gave him some capital to invest in land acquisition outside Delhi.

Singh began buying land in Gurgaon in 1979, beginning with less than half an acre near Chakkarpur Village, currently part of a residential colony, DLF Phase I. He still faced legal obstacles to acquiring land in Gurgaon district under the Punjab Pre- 
emption Act of 1913, which allowed relatives to make claims on land already sold by one member of the family. Singh studied the law, determining that it had been revoked in Punjab. "I kept on trying to convince them that such a law would seriously retard the development of the state. It took time, but after scores of meetings, things finally started moving and in due course the Punjab Pre-emption Act of 1913 was repealed" (Singh, 2011, p. 99). During this period, along with Sushil Ansel of Ansels Builders, and Ramesh Chandra of Unitech, the two largest builders of Gurgaon beside DLF, Singh would make frequent visits to Chandigarh, lobbying for changes to town planning laws.

During the period when Singh began to buy land, Gurgaon was still predominantly rural. Its farmers held no more than 3-4 acres per household, which meant to assemble the roughly 3,500 acres he initially planned for his group housing projects, Singh and his associates, dealt with nearly 700 families. His pitch involved harnessing the wasteland narrative, convincing farmers that their land was underproductive. If they sold to him, he would arrange for them to get a larger plot further out in the District or in Rajasthan with a better agricultural yield.

"We made them realize that if they sold one acre in Gurgaon, they could easily buy eight to ten acres of fertile land if they moved 20-30 kms away...It took many months, however, before they began to see the logic of my reasoning. The emotional connection was extremely strong" (Singh, 2011, p. 104).

Singh developed a strategy and a story that worked to his advantage. He canvassed in villages and embedded himself in the landscape, personally soliciting farmers, and becoming a fixture in their homes. He used his father-in-law's name, as it carried weight in Haryana, and invoked his own Jat background, presenting himself as 
an insider story of success. He also offered a partnership model, first developed by his father-in-law. In a period where it was impossible to get a home loan or finance for group housing projects, he used a strategy to recoup the cost of the land from the farmers themselves.

"After handing over the money for their land, I would ask them if they needed all that money. Invariably, they said that they had never seen so much cash and did not need it for their kind of lifestyle. I then asked them to invest the money in DLF and become partners who would progress together with us. There were times when we bought land, handed over the money and then got them to give it back to us as investment in DLF on the very same day!" It was a win-win situation for them and for us. We offered them an interest of 12\%" (Singh, 2011, p. 107).

DLF began officially developing colonies in Gurgaon in the 1980s, and immediately hit political obstacles. Whereas Gandhi had Lal's support in the initial Maruti land use conversion deal, Singh's ties, including his touted relationship with Rajiv Gandhi, did not guarantee his success with the Chief Minister. To the contrary, Singh became embroiled in a decades long battle. He had initially built a good rapport with Lal, but that informality led to a rupture in their relationship. One evening, Lal arrived unannounced to one of Singh's dinner parties where an intoxicated guest made an offensive remark. The fallout from this event, Singh (2011) claims, resulted in several charges being brought against DLF, as well as opposition to DLF's first license, in April 1981 (a 40-acre chunk of land, granted by Bhajan Lal, who also happened to be a personal adversary of Bansi Lal).

While Lal was not in office at the time, Singh claims he was instrumental in opposing the license. Lal apparently pushed Bureaucrats to acquire a license to develop land around the acreage DLF was assembling to block a contiguous parcel. 
"Ostensibly the purpose of the acquisition by the Haryana Housing Board was to construct houses for medium and low-income groups. The measure was obviously targeted at DLF for the area covered under the notification would make it impossible for us to extend our reach beyond the land we had already acquired" (Singh, 2011, p. 122).

The decision had been taken without approval from the Directorate of Town and Country Planning, a last-minute notification that the Housing Minister had signed without more than a glance. Singh attempted to persuade the Minister, mentioning his relationship with Rajiv Gandhi. Again, the Gandhi name prompted a conversion of land use. The documents and drawings were submitted, pushed through the office of Town and Country Planning with follow up meetings, and eventually the land surrounding DLF's holdings was "denotified” back for private sector acquisition (Singh, 2011, p. 122).

"Armed with the de-notification orders, I happened to meet Bansi Lal and told him what had happened. He was quite surprised as the original notification went against the policy that his government had formulated." Lal began an inquiry immediately after this. Meanwhile, he was again Chief Minister in 1985, suspending the Director of DTP who had favored DLF in the early 1980s. Lal asked his new Town and Country Planning Minister to cancel DLF licenses, which caused widespread panic and media coverage, to the detriment of DLF, and an investigation by the Haryana Vigilance Department in 1986 (Singh, 2011, p. 124).

Thus, began a campaign in which Lal's administration targeted DLF by blocking permits, filing charges, and using the media. "His bureaucrats planted stories which were slanted against private sector developers" (Singh, 2011, p. 126). Among the obstructions Singh recounts were canceled construction of a road meant to 
decongest traffic near DLF group housing colonies, a project that was eventually resumed in 2003 after numerous Resident Welfare Association (RWA) protests and a new Chief instated. Lal also introduced a policy permitting licenses to develop a commercial area at a minimum of two acres, allowing hundreds of smaller developers to enter and build on MG Road.

"In the original plan, such commercial activities were spread out to ensure that traffic and infrastructure facilities do not get overloaded in one area. Unfortunately, Bansi Lal's ad hoc decision making destroyed DLF's and Rajiv Gandhi's too, vision of setting up a world-class city" (Singh 2011, p. 133).

The Lal administration's attempts at targeting the private sector (DLF) also included an effort at acquiring land for a HUDA funded golf course to compete with DLF's signature Arnold-Palmer designed course, a plan that ultimately fell through due to lack of funds. Singh notes that Lal's relationship to Rajiv was not as close as it had been with Sanjay. Eventually Lal's ties to the Gandhis loosened, and he formed the Haryana Vikas Party. Singh put pressure on Gandhi at several occasions, after he was elected Prime Minister, to appeal to Lal and reinstate the license. Under threat of arrest from Lal, Singh had armed himself with an attorney, ready to fight accusations and for the reinstatement of the licenses when Lal suddenly stepped down in 1987.

After Lal left his second term as Chief Minister (1985-1987), his successor, Devi Lal, also his adversary, became convinced by a competing real estate developer, H.L. Sanghi, that HUDA should take over land development entirely from the private sector to benefit state revenues. Sanghi became head of HUDA, though only for a year before his idea proved unfeasible. Devi Lal reinstated DLF's licenses in 1989 as the 
company struggled to assemble land, borrowing at $24 \%$ interest. Then Bansi Lal returned for another, final term as Chief Minister.

In subsequent Chief Ministers, such as Om Prakash Chautala, Singh found an advocate for IT-related real estate ventures like DLF Cyber City and eventually a long-term ally in Bhupinder Singh Hooda, who took office in 2005. Singh praises Hooda as "sophisticated and imaginative," as possessing a "forward looking attitude". Singh forgives Hooda's shortcomings, again noting that HUDA could not keep pace with private sector growth, and that the revenues the agency collected could not be adequately managed or spent on infrastructure improvements because of “organizational and procedural limitations" (Singh, 2011, p. 199). Ultimately, Singh called for what many in the real estate business in India have also championed, the strengthening of an urban local body and local planning authority to oversee development.

In the 1990s, DLF added group housing projects to their roster, followed by commercial office spaces, and malls in the early 2000s. Cybercity broke ground in 2003. In the subsequent years, luxury and IT parks were built. By 2007, a year before Gurgaon achieved municipal corporation status, DLF went public.

Singh speaks little of the building trend that began because of or alongside DLF, and is, in fact, highly critical of the competition. As DLF lobbied for reforms and churned up the real estate market in Gurgaon, hundreds of smaller enterprises and real estate ventures came in with the tide. DLF had pioneered a model of doing business in Gurgaon. Many projects are currently financed by home loans to individuals, who pay in installments, providing capital for construction costs. Among 
the more corrupt iterations of this was the "pre-launch" or "soft-launch." This practice involved selling apartments before licenses or full ownership of the land had been obtained. While this was outlawed in Haryana in 2007, instances of it continue in Gurgaon. Speculation has caused the city's housing and land prices to skyrocket. Many farmers along Gurgaon's fringes eagerly welcomed private developers to their land to avoid anticipated state seizures, which would mean lower compensation (Donthi, 2014).

Singh was transparent in his desire to play the role of the master-builder and was quick to target Lal for many of Gurgaon's current problems. "Bansi Lal felt that enough had been done for Gurgaon. He had diverted his attention from Gurgaon mainly because it was being developed by DLF...It would have been the best city in India and an important investment destination in Haryana" (Singh, 2011, p. 137). It is difficult to know how much of Singh's portrayal of the feud between himself and Lal is myth, or a way of deflecting criticism of the role DLF played in shaping the built environment of a city currently facing so many criticisms. Singh briefly acknowledges that there was also, perhaps, an ideological chasm between them. If the original Architect of Haryana held much deeper objections to the DLF's role in shaping Gurgaon, it suggests a different meaning in the conflict between private actors and public officials, one that may be both ideological and deeply personal.

\section{Conclusion}

This chapter has described the supports of Gurgaon's central place narrative: the history and reputation of the District as a culturally backward environmental 
wasteland, the politics of failed state-led development and the political antagonists to the master vision of companies like DLF. In this narrative construction, both Gurgaon's successes and failures have an explanation, in which the wise hand of the market, and real estate developers are doing the best they can under the circumstances. In Singh's critique of his opponents, and their vociferous opposition, we may understand more about their motivations in pushing on, circumventing or otherwise altering the norms of planning to accomplish their goals. Before the prospects of a city were tangible, its proximity to Delhi, and access by road, made it an attractive location for Sanjay Gandhi's Maruti project. His relationship to the Chief Minister of Haryana, Bansi Lal, however, gave him a unique advantage in pushing through his agenda. Lal's personality and style of leadership made him beholden to powers at the center of government. When K.P. Singh came to Gurgaon in the late 1970 s, he saw the state as a progressive one, in which the type of restrictions facing Delhi could be easily renegotiated. He did not anticipate the fragility of his relationship with Bansi Lal, though he found allies in other administrations. Singh was interested in establishing a profitable real estate empire, but also ensuring a legacy that would exceed that of his father-in-law, by building a city from the ground up. Lal's first steps in rezoning land for industrial purposes, and Singh's lobbying efforts to lift land ceiling restriction laws had far reaching implications for urban development than the roughly 4,000 acres they acquired. They broke open a speculative market for hundreds of other private developers and investors to follow, radically altering the landscape and political economy of Gurgaon. 
The history of Gurgaon's early land conversion deals is more complex than the economic-development arguments that may have supported them, involving the interests, relationships and wills of individual actors, rulers, and entrepreneurs. In describing how a city like Gurgaon was made or constructed as a place of meaning and value for its inhabitants, origin stories become important. They can be used to serve political, economic and social agendas. They can influence direct intervention in planning, and work to erase or lift certain individuals or communities or implant a false narrative to distract from planning failure. In Gurgaon's origin story, the lines begin to blur between mythological and modern (or millennial) stories of corruption, dispossession, and progress.

The danger in letting these narratives do the work of placemaking is observable today. The Millennium city's fictional urbanism heroized real estate as the rehabilitation of backwardness. But as Chapter 5 will later explore, the subjects of that wasteland narrative have not disappeared, but remain as strong political and economic actors who control the city's low-income housing market and municipal ward seats. Their working through the implications of their place in the overarching story of the millennium city is far from over. It is a negotiated role still very much rooted in a place that is gone, and while paid for, never properly compensated for or grieved. 


\section{CHAPTER 3: PLANNING THE MILLENNIUM CITY}

\section{Introduction: The Prodigal Planners}

The hotel near HUDA Gymkhana Club, in Old Gurgaon, was set up for several hundred attendees. A TV crew and local newspapers swarmed the stage in the ballroom where Gurgaon District's Town and Country Planning Department representatives were seated in a row. The table was festively sashed and covered with brochures from real estate developers, business cards and name plaques. Hotel staff darted around serving chai and biscuits, small plates of samosas and pakoras; a snack before the main lunch buffet would take place on an outdoor terrace.

At the front of the room was a large clear plastic raffle drum, for transparency. This was also the reason for the camera crews. Gurgaon's town planners, including the District town planner, the Senior and Assistant town planners, were engaging with the public today, conducting what had become a bi-annual affordable housing lottery draw. As numbers were called, participants, who had come from all over the NCR that morning, eagerly scrambled to the front of the room towards lottery administrators to confirm their identities and claim their prizes: a bid on a small apartment by an affordable builder.

Sample floor plans for buildings still in the permit stage were scattered across the four or five different developer tables at the entrance to the hotel. The average two-bedroom apartment in Gurgaon goes for anywhere from 50 to 300 lakh. $^{78}$ At just

\footnotetext{
${ }^{78}$ One lakh is equivalent to 100,000 Rs. In USD this is between $\$ 70 \mathrm{~K}-\$ 400$ (as of 2019 exchange rates).
} 
under 20 lakhs, albeit at reduced sq. footage, the offerings today would enable a broader swath of the middle- and lower-middle- classes to consider homeownership in Gurgaon. The opportunities on auction (access to a market of starter apartments) were part of a mutually beneficial deal between smaller developers, the non-DLF, UNITECH, Ansels, or IREO developers, and Haryana government in support of a middle-class dream. As one planner explained in the car on the way to the hotel, "everyone wants to own a home." This statement was made by many participants during the research, usually in a wistful tone by homeowners and in a cheerful one by real estate developers. There was something cynical about its use in a context where the lines between public interest and profitability had been redefined or erased. Planners knew quite well that the desire for homeownership, as a normative aspiration, would benefit public revenues.

The assured knowledge among the planners that everyone wants a home was reflected in the enthusiasm of the crowd, yet none of these homes had been built. When a raffle winner secured their bid, it would be for a home they had not personally selected or ever seen, except in a digitally rendered floor plan, and even then, without choosing its location. Even though most of these families would be "genuine residents" of their future properties, the issue of location did not seem to matter, only the cost and the opportunity of the deal. The home would be in Gurgaon, and that was the point. The Planners were right to a certain extent. Ownership was everything. It was assumed the rest would be worked out later.

The affordable housing lottery was performative, from the clear plastic raffle drum and camera crews, to the free lunch and talk of affordability. The "bread and 
circuses" quality of the event was responding not only to a need, but an audience sitting in judgment of town and country planning and its operations. ${ }^{79}$ There was trouble in the relationship, and the event gestured towards reconciliation.

The exploration of the professional life world and the cognitive and communicative tasks, decisions and processes that fill it with meaning is the subject of an entire genre of planning literature and theory (Forester, 1999, 1989; Innes \& Booher, 2010; Campbell, 2012; Healey, 2007). ${ }^{80}$ As many scholars have pointed out, working in the Global South perhaps requires a different set of assumptions (Watson, 2009; Roy, 2009; Yiftachel, 1998). Work on the materiality of bureaucracy and the structural violence of weak state governance often uses the institutional practice of planning and the planner's life world as a heuristic for understanding political culture (Gupta, 2012; Hull, 2012). These portraits are difficult to recuperate or bridge with the pragmatism of a practitioner centric view. To look at planners in isolation or to attempt to build this bridge is not the central project of this dissertation. However, a perception of their absence, abandonment or failure informed how participants in the research felt about the city as a place. As later chapters will explore, residents look to real estate builders for support in the material reproduction of the city, but when that breaks down, the responsibility shifts to planners and local government to intervene. Planning was a concept with deep significance for individuals and communities, and

\footnotetext{
${ }^{79}$ Björkman, L. (2015). Pipe politics, contested waters: embedded infrastructures of millennial Mumbai. Durham: Duke University Press.

${ }^{80}$ For those who study the social world of practice and practitioners, work like Schon's (1984) conceptualization of learning-in-action in his Reflective Practitioner has had deep reverberations in theories of planning practice. Schon, D. (1984). The Reflective Practitioner: How Professionals Think in Action. Basic Books.
} 
their stories and residential histories were filled with episodes of engagement with planning institutions. The realm of state-sponsored practice was also an important piece of the Millennium city narrative. As discussed in the previous chapter, this was a brand that touted the role of private builders in a city without planners, or at the very least, worked to undermine their credibility. I heard from informants that there were no planners, there were not enough planners, there were too many planners, or that they were corrupt, mired in red tape, unimaginative, biased, or simply behind the times. By partnering with the private sector, planners seemed to confirm many of these criticisms simply by accepting the support of a public-private approach. What has resulted from this acceptance has not been a true partnership, however, but a system that often keeps planners in the dark about the work done with their blessing. While they have retained marginal authority in Gurgaon, they have also outsourced the very processes that generate social capital, local knowledge or understanding of place that lead to place-based expertise.

In recent years, Haryana has attempted to remedy this by fully establishing the urban local body, as per the 74th amendment, pushing the MCG to take over many of the tasks and responsibilities previously performed by private builders. This retroactive effort to step into the role of planner, after a long-perceived absence, has created drama, to say the least. The debate centers around whether residents are better off self-governing through RWAs and NGOs, or supporting a strong, autonomous local government to look out for their interests. Many of the episodes discussed in this dissertation involve moments where residents, as placemakers, successfully implemented their own visions for conservation or improvements to the built 
environment, only to experience frustration when local government offered to take these responsibilities off their hands. The response to government takeover was typically fear of incompetence or exploitation. As I argue in this chapter, these sentiments, both that planners either do not know what they're doing or can't be trusted, are backed by substantive empirical evidence, but are also reflexive and mutually dependent problems that have undermined respect for the profession in Gurgaon.

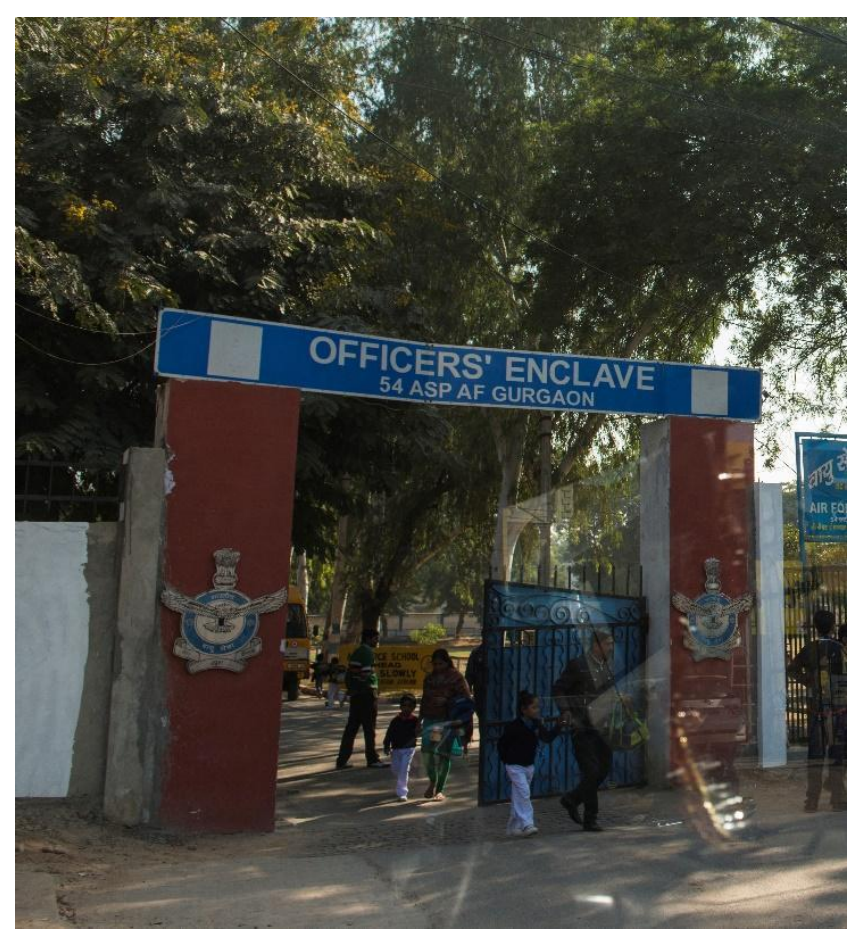

Figure 3: Visit to a planning office in Gurgaon. 


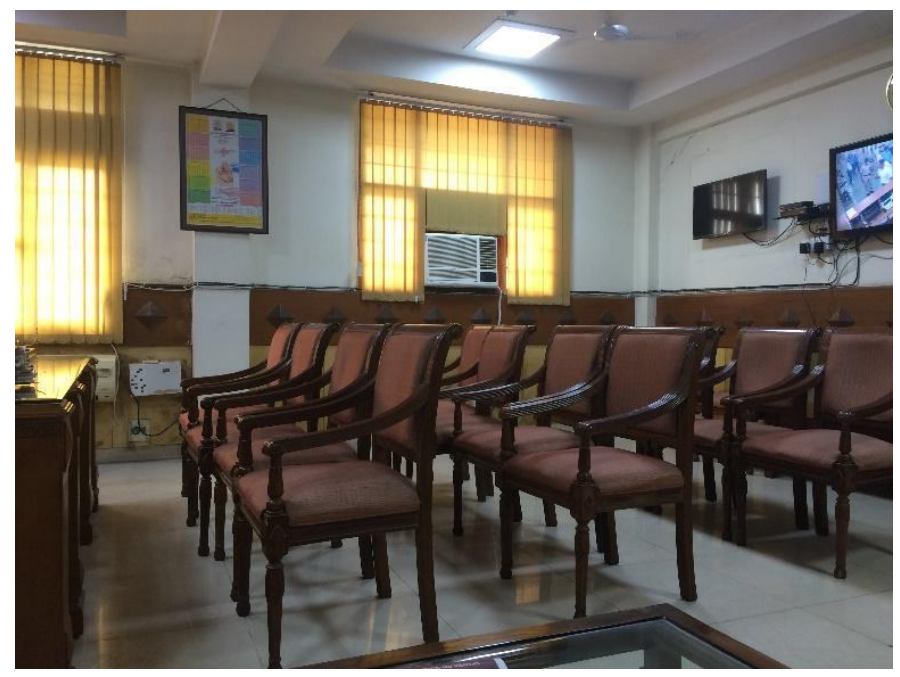

Figure 4: Visit to the Deputy Commissioner's Office of the MCG.

Professional planners in India are often appointed from the roughly 4,800 member Indian Administrative Service (IAS), a bureaucratic cadre that recruits through a difficult examination process. Once initiated, Officers are promoted by seniority within the institution. Those who work explicitly in planning agencies or on related issues, may or may not have a planning education. Officers work on short-term posts, a practice carried over from the colonial era civil service, on which IAS is based. On average, an IAS Officer spends 16 months in a post. There's a 53\% chance that they will be transferred in a given year. This rises to $63 \%$ if there's a new Chief Minister in office. ${ }^{81}$ What is striking about this is its consistency with the ways in which the Civil Service operated in the 1930s, or what Potter (1996) refers to as "the main ingredient of the ICS tradition," despite the profound changes to other aspects of urban development and management. This so-called "transfer raj" is meant to

\footnotetext{
${ }^{81}$ Vaishnav, M. and Khosla, S. (2016). The Indian Administrative Service Meets Big Data. Carnegie Endowment for International Peace. Working Paper. Retrieved from: https://carnegieendowment.org/2016/09/01/indian-administrative-service-meets-big-data-pub64457
} 
discourage the kinds of relationships, presumably with local business interests or elites, that might lead to corruption. Yet the worst offenders find a way around this. Currently, the Central Bureau of Investigation has six cases of corruption against the former Haryana Chief Minister, Bhupinder Singh Hooda along with Robert Vadra (son-in-law of Sonia Gandhi), of DLF. The most recent case involves a 50-acre piece of land in Gurgaon District. Hooda, Vadra and DLF operated the scam by invoking section 4 of the Land Acquisition Act of $1894,{ }^{82}$ offering to buy land from tenant farmers. DLF would then offer a slightly better deal in order to pressure the sale.$^{83}$ If this was unsuccessful, section 6 would be invoked ${ }^{84}$ and farmers would receive formal notice of the government acquisition. Once they had sold to private builders, state government would grant all permissions and land use conversions, while the land's value would increase substantially beyond the price at which it was purchased. The man who called out this scam, incidentally, was a locally posted IAS Officer, Ashok Khemka. Now in his 51st post in the course of his 24-year career, Khemka has become the poster child for the punitive transfer raj, and an example of what happens when an IAS Officer blows the whistle on institutionalized corruption but refuses to leave the service. ${ }^{85}$ In 2018, Khemka was appointed Principal Secretary of Haryana’s Sports

\footnotetext{
${ }^{82}$ Land Acquisition Act 1894. Section 4 is a notification of a preliminary investigation into acquiring land for public purpose. Served as the first shot across the bow to alert the public of the government's interest in the acquisition.

${ }^{83}$ Pubby, V. (Feb 2018). Manesar Land Scam: Long Battle Awaits Bhupinder Singh Hooda as Shady Deals Return to Haunt former CM. First Post. Retrieved from: https://www.firstpost.com/india/manesar-land-scam-long-battle-awaits-bhupinder-singhhooda-as-shady-deals-return-to-haunt-former-haryana-cm-4334681.html

${ }^{84}$ The 1894 Land Acquisition Act, section 6 refers to formal notification of government acquisition.

${ }^{85}$ Khemka was formally invited to join Delhi's Aam Aadmi party and run against Singh Hooda for Haryana Prime Minister in 2013.
} 
and Youth Affairs ministry, in charge of organizing a high stakes dangal (wrestling)

competition, a task he informed journalists he was looking forward to. ${ }^{86}$

A study conducted in 2015 found that the most common indicator of success for IAS Officers, or the rate of delivery on projects, was embeddedness combined with low rates of corruption. ${ }^{87}$ By embeddedness ${ }^{88}$, the study referred to the degree to which Officers had deep local knowledge or familiarity with the context in which they were working, either through sustained work and habitation or because it was their place of origin. Corruption, the paper also argued, was the lowest in environments in which the Officers faced the most public scrutiny. ${ }^{89}$ The study seemed to pick up on the important relationship between knowledge and intention in planning practice. ${ }^{90}$ Without the public's interest as a guide, embedded knowledge could be used for selfinterest. But planners with good intentions who lacked embeddedness, also lacked contextual knowledge and the time to achieve their goals. Meanwhile, monopoly

\footnotetext{
${ }^{86}$ Siwach, V. (Mar 2018) In 51st posting as IAS, Ashok Khemka gears up for dangal in Haryana. Indian Express. Retrieved from: https://indianexpress.com/article/sports/sportothers/ias-officer-ashok-khemka-gears-up-for-a-new-dangal-5105150/

${ }^{87}$ Rikhil Bhavnani and Alexander Lee analyzed data on 4,800 IAS officers, working between 1991 and 2001, searching for a relationship between working in one's home state and the quality of service delivery, using allocation of schools as a measure. There are many problems with attempting to quantify successful outcomes in IAS administration along any measure, but the decision to use this indicator in the study acknowledged that similar outcomes could not be predicted or expected for public works delivery, at least not in a generalizable way. School construction turned out to be the most easily captured indicator across locations. Bhavnani, R.R. and Lee, A. (2018). Local Embeddedness and Bureaucratic Performance: Evidence from India. The Journal of Politics. 80(1):71-87.

${ }^{88}$ Evans, P.B. (1995). Embedded Autonomy: States and Industrial Transformation. Princeton, NJ: Princeton University Press.

${ }^{89}$ Bhavnani, R.R. and Lee, A. (2018). Local Embeddedness and Bureaucratic Performance: Evidence from India. The Journal of Politics. 80(1):71-87.

${ }^{90}$ Forester discusses the history of "good intentions" in planning theory and the link, explored by John Friedmann, between knowledge and action. Forester, J. (2012). From Good Intentions to A Critical Pragmatism. in The Oxford Handbook of Urban Planning. Oxford: Oxford University Press.
} 
corruption was free to thrive at the state level, as in the case of Haryana. Constant transfers and house sorting of bureaucratic appointees, as I will argue in this chapter, has also created an environment in which crisis becomes the call to action, as Officers learn which problems to prioritize, juggling the day to day stream of public meetings. There is some irony to this frenzy, given the general assumption about the slow pace of Indian administration, or any bureaucracy, for that matter. This mix of temporalities, the crisis of the moment, and the slowness of results are related: the practice of planning, as a series of discrete tasks, becomes dislodged from the longterm, occurs on paper (through its production and management). In the rush to solve one problem after another, as one participant put it, "planning becomes jugaad". 91 This style of ad hoc problem solving and favor currying may compensate for but often lacks the rewards of institutional memory, progressive change, or gradual practices, and precludes the possibility of long-standing trust between planners and their publics. Solving a problem often requires rising above the emotional turbulence of complaint and, rather than taking immediate or short-term action, devising solutions that are based on a broader understanding of where a complaint sits in relation to other problems. In other words, simply listening to the public or responding to problems in

\footnotetext{
${ }^{91}$ A popular Hindi/Punjabi term that refers to a way of solving problems or accomplishing tasks through low cost or temporary solutions. It is typically associated with improvised fixes around infrastructure, tools and other objects with mechanized or moving parts. Often a pejorative term, implying something is cheaply made, jugaad has become valorized by business and management communities in recent years as a style of innovation born from the resource constraints of India, with valuable lessons for international business. The Financial Times lexicon states: "Jugaad is about extending our developed world understanding of entrepreneurial spirit in the traditional Schumpeterian style." Retrieved from: http://lexicon.ft.com/Term?term=jugaad-innovation.
} 
the moment, is not participatory planning in the highest sense, but functions as an institutionalized form of clientelism, a performance.

The rest of the chapter is organized as follows. The first section discusses the most common critiques of professional planning practice as they were discussed during fieldwork, in relation to Gurgaon, but also in terms of the broader conversations on these issues in India. The next section focuses on the issue of embeddedness, and why fear of it has historical roots in the trauma of colonialism and postcolonial governmentality. The third section discusses the privatization of planning or "microplanning", and the results of this process. Finally, the chapter concludes with the role of planners, since the 74th amendment, and reflects on how attempts to ameliorate the above grievances by listening to the public are most effective when they go hand in hand with sustained practice and embedded or place-based knowledge.

\section{Common Critiques of Planning in India}

"There's nobody above IAS in this country. That is what we boast... it's not very true, but we call shots very informally wherever we go."

-Deputy Commissioner, Gurgaon, 2016

During fieldwork, I heard many critiques of planners. Some of them were based on perception, or frustration with outcomes, and many were backed by scholarship on the efficacy of Indian administration. It becomes important to understand how many of these perceptions or genuine critiques relate to one another in practice. The first critique, usually an off-hand remark, were statements to the effect of: "There are no Planners." The idea that planners do not exist is probably not worth engaging with. As the previous chapter and the affordable housing auction illustrates, 
the planners have always been there, just not in the ways that participants might have hoped for or expected. Common critiques of planning practice, discussed by laypersons and professionals alike, include the following.

\section{There are Planners, but not enough of them.}

It is difficult to assess the human resource needs of Gurgaon's planning authorities without looking at the substance of the work, understanding the everyday demands placed on the existing workforce, what kinds of tasks may be thrown by the wayside, and why. What do planners do? What should they do? What constitutes impact? The statement that there wasn't enough qualified manpower on the job was often reiterated by planners themselves. Throughout fieldwork, statements about a "lack of capacity" from government bureaucrats were frequent. For example, a resident of a gated colony described her efforts to stop waste fires beyond her boundary wall, and kept hearing the refrain, "we lack capacity" from the Municipal Commissioner's office. It appeared there was no arm of the agency tasked with vigilance or the ability to monitor violations or file FIRs against builders illegally dumping or burning construction waste. $^{92}$ Furthermore, since local government had not identified alternative dumping sites, they had taken a lenient stance to these violations. The Deputy Commissioner at

\footnotetext{
92 A First Information Report is a document prepared when a complaint is made to the police or other authority about the violation of a code or law. Many of the "planning problems" reported by informants in the research were illegal activities, and filing these reports was the first step in initiating a process of resolution. The use of FIRs explains, to some extent, why Municipal authorities could seem to be more responsive, since they set in motion the legal mechanisms to take immediate action or treat these issues as matters of criminal offense.
} 
the time, a man admired by many of the participants in the research, admitted as much in interviews:

"Whether you are taking action or not, our regulators framework is large, but our regulatory capacity is constricted, and some days they go and make an inspection, give a notice. We don't have so many people. At the same time, MLAs and other people will [say] "don't do this." I told them it's ok, do the saf karna ${ }^{93}$."

-Interview with Deputy Commissioner of Gurgaon, 2016

In this episode, the DC explained how, despite their limited human resources, his office had gone above and beyond what elected officials (MLAs) had recommended by cleaning up a polluted site. While his wing of government might have benefitted from more employees on the job, the statement itself, that an agency is understaffed or lacks capacity, also functions as a rhetorical device that maintains a relationship between planners and the public. This frequent mea culpa could serve to both address public concerns and lower expectations. Rather than take a defensive stance, planners position themselves as limited, which may make their accomplishments appear even more impressive. Such statements also carefully deflect responsibility. "Our regulatory capacity is constricted" refers to the complex web of actors and agencies responsible for planning within the city. In other words, the problem was not just one of manpower, but of roles and responsibilities. The DC presides over a regulatory body that makes inspections, collects revenue and mediates disputes, but the work of "saf karna" may be someone else's job.

2. Maybe there are too many Planners.

93 Saf (clean) karna (to do) meaning the "clean up". 
Absent entirely from the affordable housing auction at the beginning of this Chapter were the DTCP and HUDA, the authorities responsible for implementing and maintaining plans, as well as the de facto owners of much of Gurgaon's disputed land. ${ }^{94}$ If anyone could assist the MCG in its vigilance and maintenance work it might be these other agencies. This multiplicity of voices, many argue, has created silos of authority and knowledge, fragmenting each agency's control to a point that becomes tantamount to absence. This leads to the next major critique.

\section{Bureaucracy itself is to blame.}

In Gurgaon, this is sometimes an issue of territory. The MCG and HUDA have authority over different portions of the city's land. If a resident sees a violation, a broken traffic light, or a road that needs repaving outside a gated colony, and can identify who controls that land, whether they are dealing with the local government or the state authority makes a huge difference. Local government in Gurgaon is far more likely to respond to resident complaints about such matters if they are made through FIRs. However, as the DC pointed out, the fragmentation of authority is not just a matter of geography. HUDA is restricted to the implementation of plans and is populated with technical officers such as engineers and draftsmen. ${ }^{95}$ Environmental decisions and approvals fall under different agencies, and Gurgaon is also subject to

\footnotetext{
${ }^{94}$ During an interview, a HUDA representative asked why I was interested in the agency if I was studying planning. They were not planners, she explained. They did urban development. ${ }^{95}$ While HUDA and the DTP have been the primary public planners of Gurgaon, the MCG's entrance, seemingly after the fact, demonstrates that the role of a town planner is not, and has never been, to plan a city from the ground up. Given India's population restrictions on which cities and towns can qualify for Municipal Corporation status, it is impossible for a city of Gurgaon's size to be planned by a Municipal Corporation. Rather, the planners at the MCG step in retroactively.
} 
the National Capital Region master plan. Development Authorities, District Magistrates, Municipal Governments and Town and Country Planning Authorities, the Forestry Department, the Pollution Control board etc. all deal with planning, broadly conceived, but do not recognize planning, ontologically speaking, as an integration or coordination of their various mandates. As an informant at HUDA stated, "We are not a planning authority. We do urban development." For many, the role of planner begins and ends with the drafting of masterplans. While it is true that this system prevents integration of activities, or efficient coordination between agencies, one could argue that even within the scope of a municipal government, a bureaucrat could do some good, which leads to the next critique.

\section{Government Bureaucrats are corrupt.}

There are structures in place designed to make administrators visible and available to the public. Officers have open hours where the public is free to come and make comments. I often used these hours to conduct interviews, make introductions, or observe the everyday practices of office work. Throughout the research, I heard stories of corruption, as well as numerous examples of Gurgaon's administrators' earnest attempts to counter this narrative, including aiding local RWAs trying to extricate themselves from an exploitative developer. For all its performativity, the affordable housing auction, at the beginning of this chapter, was a gesture for the public towards transparency and accountability. There are innumerable stories of bureaucrats avoiding nice clothes or tailored shirts and watches at the office for fear of being accused of corruption. The image of the humble public servant had to be maintained even among those for whom it was an accurate description. Projecting authority and 
respectability in the face of severe scrutiny, while observing the norms and expectations of belonging to a community of practice that offered temptation to do just the opposite, was all part of the job. I encountered Officers who were tired, going through the motions, running from one meeting to the next, trying to get through the day, or get through their time in the trenches until they could be posted back in Chandigarh or a more pleasant locale.

This notion of biding one's time in the gig until a better post came along leads to the next point, one that was not raised by residents, but by planners themselves. Planners do not get to choose where they work early in their careers. Gurgaon has been thrust upon them, a knot of wicked problems that they can observe, or puzzle over for a few years before they can move on. They are not required to think too deeply about its meaning and value for those who have formed attachments to it. They are insulated from that, and for important reasons.

\section{Fear of Embeddedness}

Contemporary planning institutions in India and colonial bureaucracies and planning authorities share a direct genealogical link, and were modeled on parallel agencies operating in Britain during the colonial period (Hull, 2011; Legg, 2007; Rao, 2012). ${ }^{96}$ India's institutions are still shaped by the realities of a colonial government that developed legal frameworks, bureaucratic uniformity and segmentation, deciding

\footnotetext{
96 There are also reasons argue the learning was reflexive. Britain developed a kind of planning profession in India and at home contemporaneously. In this sense, such agencies shared more of a sibling genealogy than a parental lineage, though attitudes towards the colonized subjects of British planning efforts in India were paternalistic.
} 
not only the kinds of agencies and their hierarchies of planning, but also the kinds of personnel and human resources that would be required to fill out these bureaucracies (Chatterjee, 2004). The Indian Administrative Service (IAS) was founded in 1946, adapted from the Indian Imperial Service, established from late 19th century British colonial rule. ${ }^{97}$ The Indian Civil Service or the Imperial Civil Service came to prominence after the 1857 sepoy mutiny, when the British East India Company formally ceded its control of the colony to the crown. ${ }^{98}$ Initially open only to white British citizens (recruited exclusively in Britain and excluding Anglo-Indian subjects as well), the service began to recruit Indians for lower level administrative posts only after World War I, though promotions among Indian ICS officers were limited (Legg, 2007).

During the decades before independence, recruitment of British subjects into the Indian Civil Service fell dramatically, and the agency drew more heavily on local manpower. During the movement for independence, ICS drew criticism for its uselessness in the cause, staffed by Indians working to promote British policies.

Planners working in the early planning agencies of Delhi had a more permanent role. Delhi was unusual in this sense. The Birla Committee's report in the 1950s identified the ways in which the post-colonial Delhi Improvement Trust had failed to provide or adequately plan for the city. The main critique in the Birla Report regarded the continuance of slums and those who inhabited them as interconnected:

${ }^{97}$ Krishna, A. (2010). Continuity and change: the Indian administrative service 30 years ago and today. Commonwealth \& Comparative Politics. 48(4), 433-444.

${ }^{98}$ Potter, D. 1996 [1986]. India's Political Administrators: From ICS to IAS, Delhi: Oxford University Press. 
"The slums hold us back; while they exist, the roots of our civilization are rotten and our corporate existence as a people is diseased." The Delhi Development Authority (DDA), the first planning agency of its kind in India was established to undertake the massive task of resolving these issues in the new capital and planning for the city in 1957 (Sundaram, 2011). Delhi is peculiar in many ways: as both a city and a Union Territory, Delhi may function as a state whose center coincides with an urban body. In the post-partition era, experiments in urban planning, as well as new agencies and institutions, came into existence to meet the demands of a republic. These reflected the mentality of a strong state taking up the responsibility for educating its people in liberal democratic citizenship (Hull, 2011; Roy, 2007). This history has created a conflicted and uneasy relationship between planning and placemaking. Legacies of administrative rigidity and corruption pervade the public's imagination and skepticism of planners as members of a government insider's club with political patronage relationships. Even well-meaning attempts to plan for or with communities speak to the trauma of British colonial efforts to understand and govern through local knowledge and embeddedness. In other words, community development, as a state-based urban planning practice, has both colonial and post- or neo-colonial histories in India, where local knowledge was used to rule, extract revenue, or foster social order rather than serve the public good. Furthermore, its professional tools were often limited to physical planning and the drafting of land use and zonal plans. The implementation, enforcement or adaptation of such plans, once they are generated, often falls outside the planner's purview to a range of parastatal agencies. This is not to suggest that Indian urban planning has only focused on the built environment in terms 
of administrative management, but rather attempts to do some variation of community development have often relied on physical planning and neighborhood design to achieve social outcomes. For example, building community or molding the ideal democratic citizen was the subject of Nehru's steel towns (Roy, 2007) and the planning of post-colonial Delhi (Hull, 2011).

Hull (2011) argues, in line with Prakash (2002), that there had always been a sensitivity among the colonial authorities to looking at "the population" as a collection of communities or differentiated cultural groups, be it through caste or religious divides. This interest in community comes from an imperative to control human populations, and often begins with knowledge production and instruments, such as the census, but continues down into the study of ethnicity and reinforcement of various discriminatory caste designations (Cohn, 1987). The use of "indirect rule" strategies in the post-1857 era of colonial governance relied heavily on this kind of knowledge of indigenous institutional frameworks. This kind of "community development" was prominent in the post-colonial era as well, for example, in the strategies of planners looking at a large influx of refugees in Delhi. Indian planning agencies attempted to socialize or coalesce such groups into place-based communities within a rapidly growing, demographically diverse city under the model of vikas mandals, or local councils (depoliticized community groups) a practice that continued into the 1970 s, eventually implemented at the national level (Hull, 2011). This model of community development planning in Delhi, involved the application of the Chicago school's "neighborhood unit," loosely applied through the Ford Foundation's work with Indian planning institutions (Hull, 2011). After the establishment of an Indian state, it was not 
simply British colonial practices that influenced planning ideas and directions forward, but US planning notions about the shape, composition, and ecology of cities, about place-based community, as well as socialist and soviet models for delivering megaprojects and state-based public works that came to bear on the institutional practices of planning (Hull, 2011; Roy, 2007).

Despite the supposed claims that planners are protected from corruption by a lack of embeddedness, they become beholden to a different context, a community of practice, in which they are indeed, embedded. This professional isolation or isolation as professional is further exacerbated by the punitive transfers for disobedience or personal cause within the IAS. This practice is particularly common in Haryana, which has the highest transfer rate of IAS officers in the country and an average post of 11 months and 25 days, albeit only five months less than the national average. ${ }^{99}$

\section{A Community of Practice, not Place}

"The fulcrum of the Indian governance system is this position, Deputy Commissioner. I have three different positions, I wear three different hats, when I sit here. One is as a collector, I take revenue courts, land record related courts, and as the District Magistrate, I will control the law and order in the city. And as Deputy Commissioner, I look after development works. And this concept of city states is not well evolved in this country, particularly in Haryana. So the Municipal Corporation is slowly gaining authority. The moment it gets full authority, this position will get sidelined, which should happen, obviously."

-Interview with Gurgaon's Deputy Commissioner, 2016

\footnotetext{
${ }^{99}$ In a 2014 survey conducted by the Time of India of 2,139 officers with more than 10 years in service participated, revealing that 13 had been transferred more than 40 times in their careers, 7 of whom were from Haryana. Retrieved from https://timesofindia.indiatimes.com/all-you-want-to-know-about-iastransfers/photostory/28561372.cms?picid $=28561440$
} 
Planning is just one administrative arm within a larger framework of urban governance in India. The practice of planning does not operate in an idealized reality of learning-by-doing, or even in an entirely abstract space of place-based ignorance but is heavily influenced by the location or context of the planner and their involvement within specific communities of practice. Communities of practice are bound by professionally circumscribed ways of approaching or defining what constitutes a planning problem, and therefore, the planner's problem (Kudva, 2008). Attempts to adapt to a changing context are mediated by a degree of individual learning on the job, but also, conversely, by a need to conform within the planner's work environment. ${ }^{100}$

In the past few decades, scholars have examined the daily practices of South Asian planners as administrators and un-elected, but nonetheless political, agents of state-power and control. For these agents, work is often abstracted from the material realities on the ground, and instead focused on its own material paper realities (Tarlo, 2003). For example, Hull (2012) has written extensively on the significance of documents in Pakistan's planning bureaucracy, that create meaning and purpose in the lives of ordinary citizens beyond mere representation. Planners' daily practices involve paper as a medium that transfers information and ideas to others, but also has performative power in the lives of their constituents. Contracts, licenses, deeds, and plans have legitimacy because they require certain steps be taken through an almost

\footnotetext{
${ }^{100}$ Schon (1984) observed that education and practice are joined, reflexive processes that continue throughout one's professional life, yet the context and professional community of planning, as a kind of learning system, may put up barriers for planners to participate in certain forms of learning-in-action, or as I argue here, develop deep knowledge that comes from embeddedness or sustained interaction with place-based communities.
} 
ritualistic observance of bureaucratic protocols. India's "document raj” also has a long and culturally entangled history that cannot be cleanly divided from colonial modalities. ${ }^{101}$ The other side to this is the undisclosed, yet more expedient, shadow of paper formality, and the conversations and relationships that speed along political decisions and deals. This information may not be part of the official materiality of planning but constitutes the politics and political knowledge inside a planning bureaucracy. Interviews and participant observation helped to sketch a sense of this realm of undocumented practice.

Initial interviews with planners in Gurgaon revolved around some of the limits and barriers to entry as well as motivation to work in the field. The findings here involve a synthesis of agency information and documents, as well as many descriptions and attempts by planners themselves to diagram the various offices and roles of different agencies in planning practice. ${ }^{102}$ The purpose here is not to provide a complete inventory, but simply to help illustrate the complexity and fragmentation of power which sits at a state or central government level.

\footnotetext{
${ }^{101}$ Raman, B. (2012). Document Raj: writing and scribes in early colonial South India. Chicago: The University of Chicago Press.

102 The Director General (an IAS officer) of the Department of Town and Country Planning (DTCP). Beneath the Director General sit two branches, the Chief technical officer for Haryana, and the Chief Coordinator for the National Capital Region (NCR), of which Gurgaon is a part (this also includes Delhi). Beneath the Chief Technical Planner, are five districts, which each have a Senior Town Planner, alongside a Senior Town Planner for enforcement and one for monitoring. Beneath the Senior Town Planners are District Town Planners. Gurgaon has a District Town Planner and a District Town Planner of enforcement in Chandigarh, the capital that Haryana shares with the state of Punjab Chandigarh is a Union Territory, with its own powers of self-governance, and the seat of both the Punjab and Haryana state governments. Haryana was part of the Punjab until the 1960s. The two states share some administrative, linguistic, and socio-cultural overlaps.
} 
Before the Municipal Corporation was established in 2008, old Gurgaon had a Municipal committee, fewer than 40 villages, which were run by panchayats. Postincorporation, the MCG remains only one agency sharing terrain with developers and HUDA. Amid this, the Municipal Corporation of Gurgaon has a fledgling planning department of its own, modeled similarly with a Chief, a Senior and Assistant Town planner, a slew of draftsmen and tehsildars who collect revenues and surveys. It is not just hierarchy but also siloes which preclude planning from seeing effective results. These silos are not just of manpower or capacity, but of information and authority. Research has demonstrated that while embeddedness does produce improved social outcomes for certain public goods, the provision of roads, for example, does not lie with municipalities, but parastatal organizations, such as HUDA. ${ }^{103}$ Therefore the onus is not just on planners to communicate with the public, but to communicate with other arms of urban and state government.

Planning happens in several Offices across the city, and in Chandigarh (or Panchkula). Visits to Gurgaon's planning offices could only take place on days of the week when Officers would be in Gurgaon. They were often in Chandigarh, where they were summoned, almost on a weekly basis, for court hearings and meetings. Over the course of fieldwork, mapping the web of agencies that controlled planning in Gurgaon became an important, if complex, task. The confusion was symptomatic of a shift to decentralize urban governance from the state to the city level, an ongoing and

${ }^{103}$ Vaishnav, M. and Khosla, S. (2016). The Indian Administrative Service Meets Big Data. Carnegie Endowment for International Peace. Working Paper. Retrieved from: https://carnegieendowment.org/2016/09/01/indian-administrative-service-meets-big-data-pub64457 
retroactive filling out of the urban local body for a city that grew up without one. Some sectors of the city were still controlled by the state authority, others by the municipality. If a problem fell outside the municipality's permitted zones, there was little a resident could do in approaching elected counselors or municipal representatives or filling FIRs. Planners generally had an open door to the public. Daily office hours allowed individuals with grievances about a plan to come in and speak to Officers directly. The constant handling of this traffic seemed to occupy a great deal of a planner's workday. The imminence of long-term policy decisions and their impacts at the local level were obscured from view by the daily cycle of smaller, discrete tasks, explanations, conversations, and adjustments to documents, plans or licenses.

One afternoon, a few weeks before the auction, I joined the Senior, Assistant, and Chief Town Planners for lunch at a hotel not far from the office. It was over 100 degrees outside, and when we returned to the paneled rooms, the stacks of papers on the desk seemed to have doubled in size. A helper served chai and biscuits, as a few men filed in and took a seat in plastic chairs with scrolled site plans. The Assistant Town Planner conducted our interview that day in slices between each meeting with a member of the public. Interviews like this one typically began with a question on educational background and attainment. Nearly all government planners in the offices, at the time of the interviews, had backgrounds in architecture or urban design, or an official degree in planning or town planning, administration, or economics. ${ }^{104}$ More

${ }^{104}$ An interesting departure from this trajectory was the Deputy Commissioner, who seemed to have more weight in terms of making planning decisions than the Mayor or any specific 
senior positions were IAS, while those in lower managerial or task-oriented positions such as tehsildars ${ }^{105}$ or draftsmen were not part of the service.

When I asked a standard graduate planning theory seminar icebreaker: "why planning?" answers were often guarded. It was implied and often stated explicitly that the Officer joined the service to meet the expectations of members of their family, or because a government job would provide security. Diverging responses came from those who might have left government service or were employed in the private sector or self-employed. Overall, the desire to work as a government planner could not be divorced from a desire to work in government more generally, and to be recognized as belonging to a specific kind of institution with career stability and a trajectory for promotion.

These two points, first regarding education, specifically an education which unambiguously pointed to planning as a future career, and secondly, the sense of obligation or responsibility entailed with joining government service, are critical in thinking about Indian professional planning practice. There was a general perception outside of the government planning offices that these actors had no formal training or interest in planning, but additional training, including sponsored education abroad was available to Officers as they attained more senior positions. The choice to become a

planning entity. The DC, during the time of research, was trained as a plant geneticist, and eventually earned a policy degree at Duke University, paid for by the IAS.

${ }^{105}$ A tehsil is an administrative unit. They can be a subdivision within a city or town, but they are below the district level and are used or have been used historically for revenue collection purposes. A tehsildar is an officer charged with overseeing, inspecting or collecting revenues within these administrative subunits. 
government employee was not accidental and required an attraction to the security and social cache of the institution.

Government and non-government planners alike expressed cynicism at the practical aspects of working with government agencies, with the usual critique regarding the slowness of conducting business with or within them. As mentioned earlier in this chapter, it was not uncommon for planners to mention they had few peers on their staff with comparable education and that their departments were understaffed. Each level within the office, at the District, State or municipal level had an Assistant, Senior, and Chief planner, surrounded by helpers, i.e. personal assistants, draftsmen, and interns. These general pool office work forces often had highly knowledgeable or skilled personnel who lacked the social status or credentials, besides experience on the job, to ever become part of the Officer class or receive the kind of additional training some of the Officers had access to. At one point, during the research, many of the city's planning offices were closed due to a worker strike when Chandigarh proposed shifting responsibility for HUDA and DTP pensions to the MCG. ${ }^{106}$ The striking workers were the administrative gatekeepers who arranged meetings and maintained the offices. Without them, the offices shut down their operations. But differences in training and recognition, as well as the closed route to advancement outside of the service, spoke to the internal hierarchy of the IAS and the planning profession. Planners worked individually and vertically when the decision merited it or took orders from more senior planners. Antagonisms might arise if

106 (Dec 2015). Staff transferred to MCG on strike, demand return to HDA. The Times of India. Retrieved from: https://timesofindia.indiatimes.com/city/gurgaon/Staff-transferred-toMCG-on-strike-demand-return-to-Huda/articleshow/55989116.cms 
someone in the service was appointed to a position of authority over someone with greater seniority from an earlier IAS batch.

The human resource issue and its relationship to the structures of decision making became the major theme in interviews, particularly how new policy directives and pressures from the Chief Minister's office would affect work in the short term. For example, the mandate of a new policy with a time-horizon of more than a few months represented an almost irrelevant deadline. There was a built-in assumption that the deadline would shift, or that some other political decree might interrupt the current policy program. If changes were required to daily practices and tasks, that decision would be made somewhere further up the chain, and changes would be made accordingly and disseminated downward. At best, one might be transferred, and it would become another planner's problem. Planners were simultaneously a product of context (Indian administration) and divorced from it. Listening to the public did not constitute embedding in and of itself, without a deeper awareness of place and the politics of various publics. ${ }^{107}$ To complicate matters further, agencies have already leased the production of urban space, place and knowledge to developers.

\section{Proprietary Knowledge and the Public Domain}

Haryana's current model of urban development, the "Gurgaon model," asks private corporations to pay fees in exchange for licenses to develop land. The key piece of legislation that enabled this model, the Haryana Development Regulation of

\footnotetext{
${ }^{107}$ In a later chapter, I discuss a case where local government built a trash incinerator at the top of an aquifer at the request of a concerned citizen. No environmental impact assessments or feasibility studies were conducted before the project was undertaken.
} 
Urban Areas Act (HDRUA) was passed in 1975. Licenses were initially reserved for HUDA projects under Bansi Lal's administration, but as Singh (2011) observed, this loosened up after business ally Bhajan Lal altered the law to promote private developers, such as DLF (Singh, 2011; Cowen, 2018). Builders or "colonizers" were also required to provide basic infrastructure (roads, lighting) as well as social infrastructure, i.e. schools, creches, or community centers. ${ }^{108}$ While some agencies oversee the construction of major roads and flyovers, water and electricity provisions, some waste management, and policing as well as government schools, in almost every category of service provision, the private sector has stepped in to boost performance, offering "non-mandatory" services for gated colonies, and some necessary ones, such as sanitation, in order to raise the standard of living.

From the vantage point of Chandigarh, the success of this model is supported by net urban and economic growth. ${ }^{109}$ The reasons for the sheer economic success of Haryana's development choices may be poorly understood. ${ }^{110}$ One planner pointed out that Chandigarh pushed a similar model in Punjab without achieving comparable results. ${ }^{111}$ The emergence of this paradigm in Gurgaon, however, was contingent, as

\footnotetext{
${ }^{108}$ Interview with State level planner, Chandigarh, April 2016.

${ }^{109}$ Estimates are roughly $38 \%$ of state revenue comes from Gurgaon. Haryana is now listed as the third largest GDP by state in India.

${ }^{110}$ The Jawaharlal Nehru National Urban Renewal Mission (JNNURM), launched in 2005, included policy prescriptions that closely resemble some of the steps taken in Haryana from the 1990s onward, particularly the lifting land ceiling restrictions.

${ }^{111} \mathrm{He}$ attributed this to Gurgaon's proximity to Delhi and the National Capital Region (NCR), with MPs, multinational corporations already in place, a population in the tens of millions and one of the largest, most trafficked international airports in Northern India. Even a common comparison between Gurgaon and Noida, the satellite city on the other side of Delhi, in Uttar Pradesh, raises the point of Gurgaon's proximity to Indira Gandhi International Airport and its unique land acquisition and development paradigm.
} 
argued in the previous chapter, on individuals and their actions, during a larger moment of policy and ideological transformation. Others have argued that Haryana constitutes a specific type of corruption narrative in terms of its urban development paradigm. As echoed in the story of Hooda's corruption charges, Gurgaon's corruption narrative is one of "monopoly corruption" rather than "serial competitive corruption", where private builders have had to pay fees, bribes and other expenditures in one go, to the state level gatekeepers in Chandigarh, streamlining the process of building and increasing the profit margins in so doing. This variable alone might explain some of the city's success compared to other states and cities attempting to replicate the "Gurgaon Model". ${ }^{112}$ On the other hand, as the auction and recent order directed at large builders demonstrates, the state has not always been kind to monopolies forming from below, and not all builders are perceived or treated equally. The megalithic or "too big to fail" developer may have the unique capacity to disrupt or interfere with the agendas of local and state government actors. Efforts to curb their monopolization, or shape land use policy in recent years have antagonized state actors and prompted policies to more evenly distribute favor among many smaller builders (Singh, 2011).

Criticisms of the role of the government-sponsored "Planner" were most pronounced among those who had either left the profession or had formal training as planners, but never joined government service. In discussing the absence of large public buildings in Gurgaon, an architect in private practice, noted that the process of

\footnotetext{
112 Rajagopalan, S. and Tabarrok, A., (2014). Lessons from Gurgaon, India's Private City. in David Emanuel Andersson and Stefano Moroni. Cities and Private Planning. Edward Elgar Publishing. https://mason.gmu.edu/ atabarro/Lessons\%20from\%20Gurgaon.pdf
} 
working with state institutions on urban design projects was notoriously difficult. ${ }^{113}$ It involved a lengthy tender and contract process, with compensation only at completion, rather than at different phases of design. The marked difference between how architects or private practitioners and public agencies conducted their practices made collaboration between them difficult, if not impossible.

In the case of large private builders in Gurgaon, not only had the costs of serial competitive corruption been eliminated by the Gurgaon Model, but many steps in the much despised collaborative process had been eliminated altogether by allowing private real estate developers to build, to conduct sales, financing, marketing and construction (and completion), within their own timeframes. Private firms were also able to rely on their relationships with outside consultants and designers to bring about large-scale urban design projects. Most large real estate development corporations had their own in-house design teams and urban planning professionals, who dealt with the logistics of what one planner could only describe as "micro-planning." Micro-planning was a process that emerged from what were often dramatic errors or miscalculations in the surveys and land boundaries designated by the municipal and state planning authorities. For example, the boundaries of a property might be off by several tens to hundreds of meters from a land use map or cadastral survey, or there might be informal settlements or roads running through the property. These discrepancies would need to be worked out on the ground, or at the micro-scale by the planners and draftsmen hired by the private developer. Many conversations back and forth with

${ }^{113}$ Interview, 2016 
government agencies would also take place. DLF's planner was a former government employee, hired on the strength of her professional experience dealing with the quasijudicial aspects of planning as a former insider. More than a design challenge, developing a plot or an assemblage of plots of land required understanding how government planners operate and think, how taking permissions and licenses would work, as well as a cultivated understanding of how land-use designations and boundaries are drawn and contested. Micro-planning dealt with the nexus of design and property/land rights questions and required a generalist who could straddle private and public professional worlds. The notion that there were large gaps at the microscale that had to be filled through survey and ground-truthing suggested on the one hand, that the private sector needed planning talent, but also that this talent, and the knowledge gathered by this process would become proprietary. When violations or land disputes occurred, private builders were the ones with the most accurate documents, surveys, or maps, while the inaccuracies of the tools available to planners in government occasionally protected them from liability, but also harmed those in the public domain in conflict with large developers, who required the support and accurate records of public agencies. What began as a lack of capacity, would become reinforced by the process of outsourcing capacity, to the benefit of the private sector and the detriment of those opposed to large builders in local land disputes.

\section{Action without Embeddedness}

The cumulative effects of the separation between micro and macro planning were often most acute in those episodes where state and local government decided to 
act in service of the public domain, whether it be handling a dispute, taking over the management of a park, or kicking in for a new public works project. These encounters of good intention were some of the most contentious ones between Gurgaon's planners and the public, as described in later chapters, such as the decision to build a waste incineration plant on top of an aquifer, leading to groundwater contamination, or the concretization of water catchment areas throughout the city. The latter, designed to catch and direct rainwater, ultimately prevented its reabsorption and led to increased flooding and damage to state-funded road infrastructure.

In each example, government responses to a complaint were clientelist in one sense, designed to appease the most immediately visible constituency. Responding to such outcries, in turn, created a new set of problems, exacerbated the situation, or excluded another public by default, like a rug that must constantly be shifted, but never covers the bare ground. Scholars have observed this relationship as one of codependence, in which the "lacks" or seeming shortfalls in state capacity belie an almost deliberate strategy of leakage. When political and state actors can provide favors or extend special relationships of access to the public for resources, such moments of follow-through and reassurance, amid an environment of chaotic incapacity, can quickly turn criticism into acceptance, and serve to reinforce a patronage relationship to governments, specifically between citizens and politicians or appointed bureaucrats (Anand, 2017). This kind of spectacle was evident at the affordable housing auction, which catered to first-time home buyers who had not yet taken residency in the city. The same week as the auction, urban village protesters had 
crowded the MCG offices with signs demanding improved water access, waiting to ambush town and country planners as they emerged from their cars in the morning.

Despite the ongoing "we lack capacity" refrain, in 2016 the state of Haryana issued an order demanding Developers hand over maintenance of completed projects to local government, with sights narrowed at DLF phases I-IV. Residents of DLF housing had publicly criticized a perceived "double taxation," the housing tax that fed State and local revenues, plus the maintenance fees to the DLF RWA and the developer for "non-mandatory" services. This response to the complaint, the wholesale transfer of governance back to the state, presents a new responsibility that many feared Gurgaon's planning agencies would be ill-equipped to handle. Not long after this decision was taken, fear seemed to have subsided that a full transfer would ever be carried out, although it began in late 2017.

On the surface, these moves are part of the slow, rocky push towards decentralization of urban governance and the strengthening of urban local bodies, via the 74th amendment. ${ }^{114}$ While terrifying in the short-term, the push to invest in the autonomy and permanence of planning actors in Gurgaon, is something both the private sector and residents interviewed in this research wished for, despite their cynicism about the current state of planning affairs. The reasons for this point back to the initial indicators of success among IAS Officers, and why having one's own locally elected authorities, with the freedom and capacity to respond to its public

\footnotetext{
114 The $74^{\text {th }}$ Amendment, passed in 1993, gave constitutional status to municipalities and required states to recognize municipalities as autonomous urban local bodies. The amendment defined municipalities and their subdivisions and elected ward systems. Participants mentioned the $74^{\text {th }}$ throughout the research as a sign of hope and promise for local autonomous government.
} 
before the demands of vertical patronage in the state centered community of practice, is so desirable. Whatever mistakes planners may have made, residents still believed they could do better. Part of this was a call for a sustained engagement with the public. Ordinary citizens, members of RWAs, NGOs, political wards and so on were willing to bring complaints to their elected and appointed officials, and to hold them accountable, recognizing that there is a role for government and a broader platform for service delivery than any individual set of actors could provide. For that relationship to work, however, planners would have to become embedded, but also grapple with the roles and responsibilities that have already been outsourced, a process that requires relationships of trust to be built and maintained, but also letting go to some extent. While embedding produces the kind of micro knowledge that informs planning for places, the freedom to self-determine, and to direct the apparatuses of planning has become part of the city's brand of civil society and may need to be renegotiated as local government enters the fray.

\section{Conclusion}

This chapter has provided an account of the planning profession in Gurgaon as linked to the historical norms and challenges of disembedded bureaucratic management, built on a legacy of colonial and post-colonial governance and institutions, including the IAS. In the present day, this approach has posed some of the most significant challenges to strengthening the municipality's urban local body and connects to the very meaning and perception of planning purpose among residents of Gurgaon and Indian cities more broadly. 
When state level planners handed over the reins to private builders, long before the establishment of the municipal corporation and its planning offices, they also handed over the process of discovery or "micro-planning" that comes with developing a piece of land, and processes by which planning expertise and public trust are co-formed. This has produced a scenario in which private citizens, builders and property managers know substantially more about the landscape and inner workings of their city, the value of certain assets, public spaces, and informal ones, and the people who make up the majority of Gurgaon's inhabitants, than the professional bureaucrats who claim authority over and plan for them. In addition to knowledge of zoning, land use and physical planning, this social capital and understanding of the political landscape of place in which one works is also part of a planner's toolkit of expertise. This knowledge goes far beyond technical knowledge and relates to the social construction of place and the ways in which authority can not only see its intended beneficiaries, but also know them, or understand them, and the material conditions in which they live. The tendency to cycle through on short appointments, the so called "Transfer Raj" has, on the one hand, been greeted by a latchkey spirit of willful independence among the more capable actors in Gurgaon's civil society, particularly among RWAs, as predicted by Harriss (2005) to some extent. On the other, this absence has contributed to a sense of abandonment among concerned citizens, who also hope for the eventual intervention and security of stable government planning. There may be no smooth transition between the current state monopoly and its attendant community of practice and forms of corruption, and the foundation of a strong urban local body, but the process is underway highlights the importance of 
location and the extent to which local governments promise not only local autonomy, but local accountability and the attention to place and its particularities that is needed to guide the decentralization process. 
CHAPTER 4: Gated Gurgaon and the Suburban Imaginary

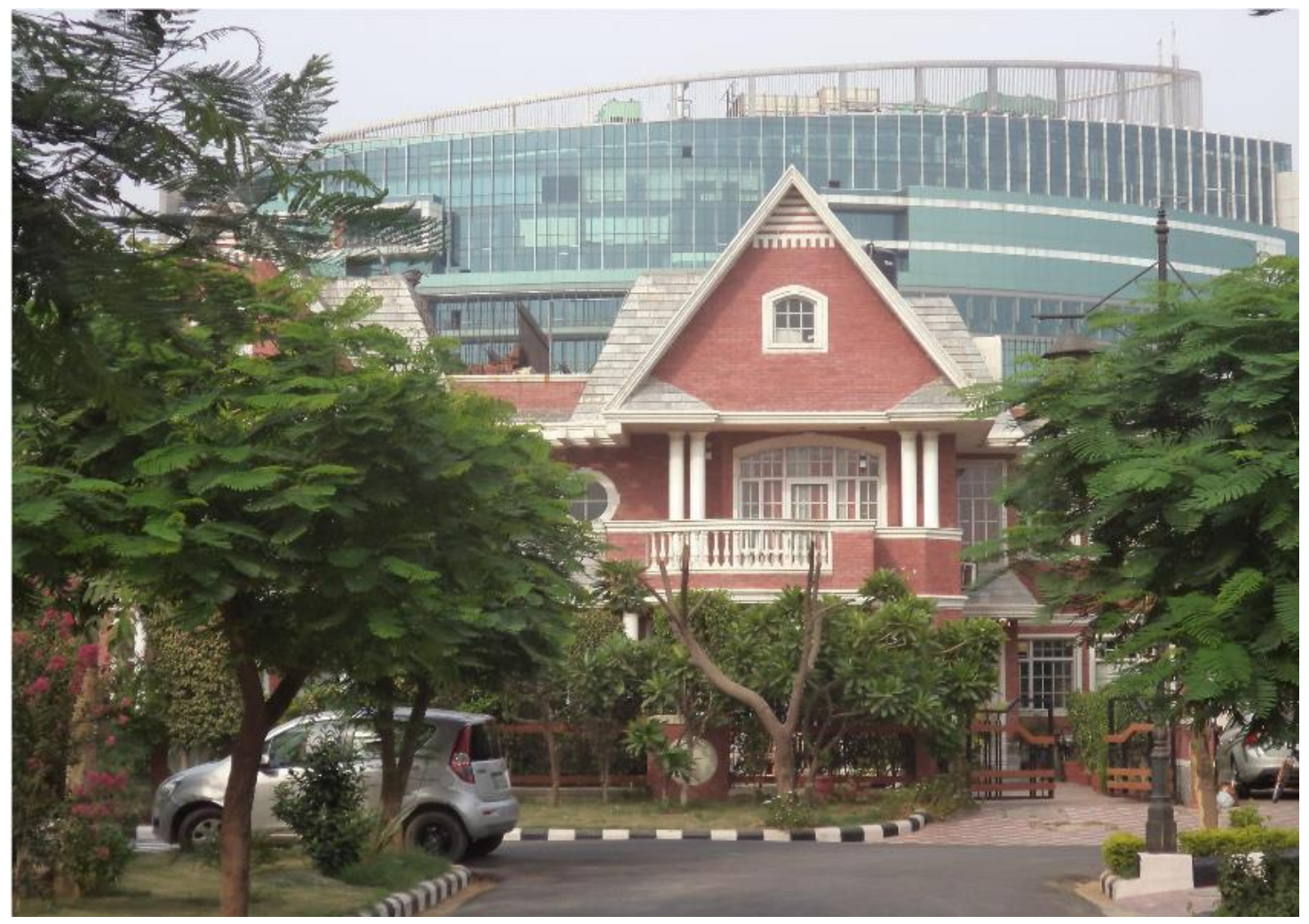

\section{Introduction: Putting Down Roots in New Gurgaon}

"It was far more beautiful then...People were actually moving at that point because they wanted green spaces...They had these ads which draw people into suburbs. It was about walking the dog in this forested environment which wasn't really there but [laughs], at least the possibility of it was there."

$$
\text { -Organizer, “I am Gurgaon”, } 2016
$$

The workers had gone home for the day, but around the house there were signs of small construction projects, half started, or near completion: a tarp, buckets, and tools, a light film of dust on everything. Homes in the National Capital Region acquire this dust daily, some of it from construction debris. Rita, my host, guided me up to a second story terrace. We stepped out into an evening breeze. The sun had set, but the concrete floor was still warm. 
"Right now, I'm in a warzone. I'm just battling all these different people; the electrician, the plumber. Somebody's coming to install an appliance, stone grinding, stone polishing...Trying to keep my patience. Everybody takes an advance...They don't show up...We keep arguing with them... The cable guy today, now look at how the guy left the wire like this."

There was a wire tangle in the corner of the balcony, a completed job. "This terrace is beautiful, though. There's something very peaceful about it in the morning. Every morning you have peacocks there. They're just preening there.”

A plastic patio table and chairs were arranged for us. Rita offered me chilled white wine and a bowl of namkeen as we talked about setting up home in Gurgaon after years away. The house was in DLF Phase III, A block extension, a plotted area with large, boxy modern homes each different, customized by their owners. Over that year, I had visited many houses on this scale (small villas) and interviewed women like Rita. With children on the verge of adulthood, or preparing to attend university, many of them were empty or near empty-nesters, highly educated, or accomplished, and had left careers or were working part-time, while running a household and juggling various projects. "I have one son. And because there's one child, the whole focus was on him, but when he left for college...I started doing a lot of voluntary work, to keep me busy."

Rita was nostalgic for the Gurgaon she knew when she first moved into her house, when her son was small, her husband's career was taking off, and both her parents were alive and lived nearby. They had a cocker spaniel. They used to play cricket in the driveway. Now, it was no longer safe. There were too many stray dogs in the neighborhood, fed on leftover chapatis. I glanced down to the street and saw one sleeping contentedly on the hood of a parked car. 
“I grew up in Delhi. I've lived in Delhi all my life. I studied in a boarding school in the hills for five years, but basically I'm a Delhi girl..." At one time a journalist, Rita dialed back her career when her son was born. When they initially located to Gurgaon, they spent a few months in Nirvana Country on Sohna Road. "There's no traffic lights or the traffic lights are not working you're just going helter skelter. It's frightening. It's funny that this part of Gurgaon is more civilized than that part of Gurgaon... when we moved here, DLF was actually quite idyllic.”

She and her husband had bought the plot for cheap. One of the draws of Gurgaon, unlike other deals in the NCR, was that the relationship with the developer allowed for greater transparency. The black money transactions involved in buying a home in India require a certain outlay of cash, undisclosed in the bill of sale. DLF required its homebuyers to make payments entirely by check or through individual home loans. "No black money". ${ }^{115}$ The couple paid off their debts quickly, spent a few happy years in Gurgaon, but then her husband's business took them abroad for years. During that time, they had lived in Hong Kong, Singapore, and Japan. Now back, after more than a decade away, they were planning to stay put, but their renovations to make the house habitable again were exhausting. There were no structural changes to be made, but they wanted a centralized stabilizer instead of one for each appliance

\footnotetext{
115 The black money economy around real estate is one of the most pervasive informal/shadow economies in India. At times, up to 50\% of a home's cost is in black money, which must be paid in cash to the seller. For a seller, this undeclared lump of cash must then be reinvested or spent on consumption. One theory behind increased speculation in real estate markets like Gurgaon is that black money must be reinvested, therefore driving demand for "investment properties". There is a problem of overaccumulation of currency that never passes through the banking system, resolved through further investment in real estate as the secondary circuit of capital accumulation/spatial fix.
} 
(refrigerators, AC units), to handle voltage fluctuation in the electricity supply, which was a problem even when they used the community's backup generator. She had no dealings with the DLF City RWA, but a smaller group of residents on A block extension.

Her family was among a handful I had interviewed who had spent many years in Gurgaon during the early days of DLF's boom, at a time when there was one other gated colony down the road, named simply 'Garden Estates' (see Figure 5). ${ }^{116}$ There was a dhaba in a shopping center across the road, beside an English liquor store. That was it. Now, DLF Phase III was encased by mega projects, hotels, hospitals, and the extension of the railway and flyovers. The changes were overwhelming. Living abroad, she explained, was easier, not just in terms of amenities, but public transportation, and freedom of movement for women.

${ }^{116}$ Garden Estates was opened for occupancy in 1990, designed by Acrop Design Group and Canada-based architect Ramesh Kholsa, winner of the Aga Khan prize. Image circa 1998, Source: Art, Architecture and Engineering Library, University of Michigan. retrieved from https://quod.lib.umich.edu/u/ummu/x-00-19322/* 


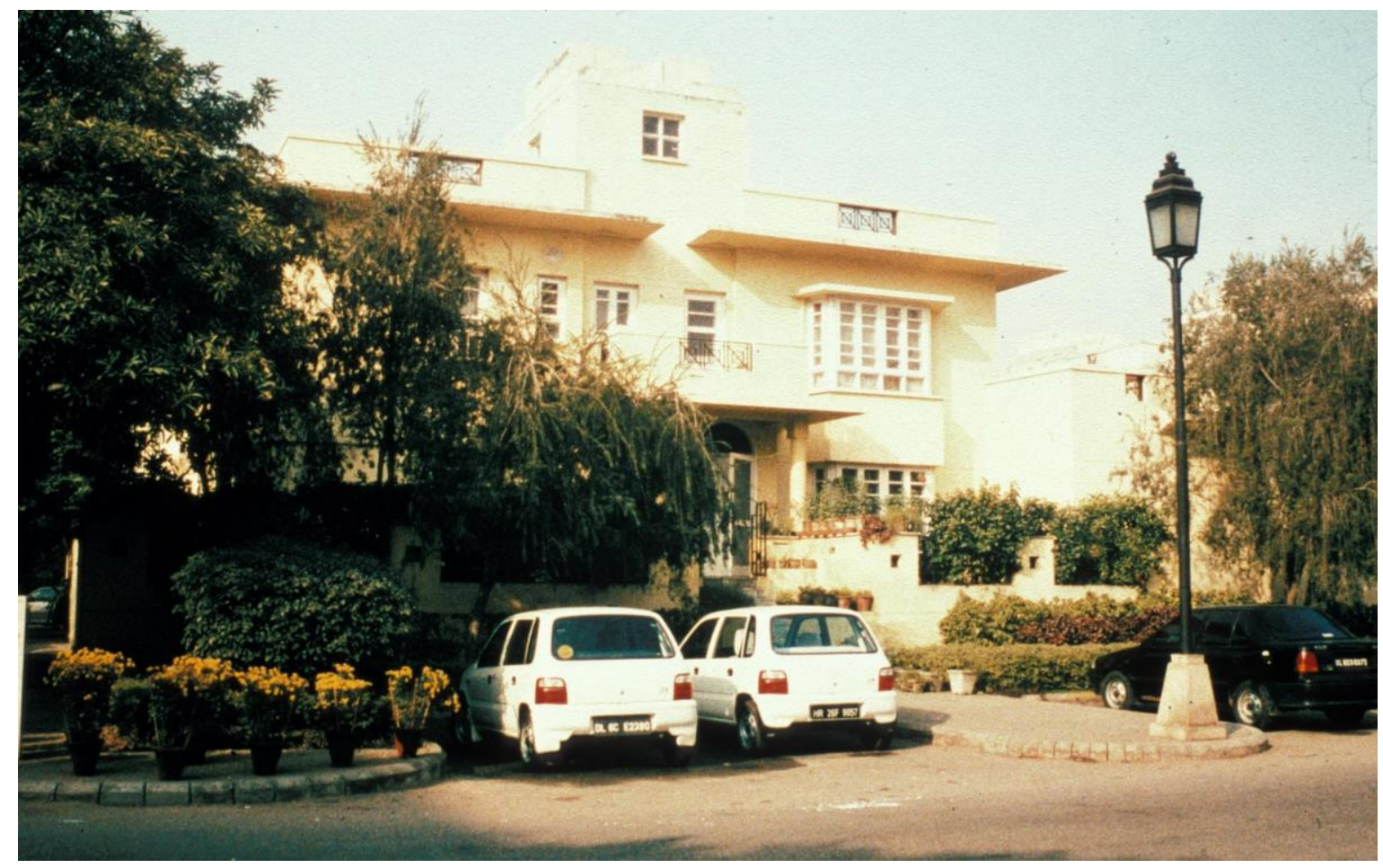

Figure 6: Garden Estates. Acrop Design Group, Principal: Ramesh Kholsa. Image circa 1998, Source: Art, Architecture and Engineering Library, University of Michigan.

At the end of Rita's block was the gate to Nathupur Village, where some of the domestic staff of A Block extension lived. Those gates were always locked. Workers would have to go around to the highway and enter the village at the main road.

Residents were also wary of the wealthier landowning villagers who spoke Haryanvi and drove too fast. There were rumors they carried weapons in their SUVs, knives or guns.

"You know the funny thing is, I feel a sense of community not with people say of my economic level but with people who are not so well off. They are the ones who recognize you, say namaste, then you talk to them. "It has been a long time." And you say "yes" and then they ask how is your son"...you know?"

As the conversation continued, Rita's servant, a middle-aged man named Aziz, originally from Jharkhand, appeared and put a plate of kebabs onto the table, and 
disappeared into the house again. He had moved with them to Hong Kong, Singapore and Japan. The four of them (her, her husband, son and Aziz) maintained what she considered an Indian lifestyle, eating Indian food, eating late in the evening.

"He's giving a lot of attitude, because he's been with us for 28 years. So half the work I have to do myself...but he has brought up our son, so my son loves him. He Facetimes with him and keeps taking his side."

As the conversation drifted into issues of class and money, the drivers, and lower middle-class workers who were gaining mobility in the hustle of Gurgaon's service economy, Rita reflected on what it meant to be elite. "The English speaking educated...we were the elite in India, the resources of this country were there at your disposal. It's not a very nice thing, but that's how it was, and that's how it still is..."

However, this kind of elite status and its access to worldly and material wealth did not seem so singular anymore. In service, and some lower administrative roles, the poor were rising into a lower middle-class, who did not share the same "sophisticated way," as Rita called it. She was self-deprecating about the things that tend to put off members of her social group, "dirt, air, and the police".

"You have this churning, this push is coming from the bottom, and they don't have that refinement, we had this sophisticated way or whatever... They're doing well for themselves. It may not be very pleasant for you. But they're doing well for themselves...it's democracy at work. It's power, numbers. So who is representing us? They don't care. We get hassled by the dirt and the air and the police. They're not bothered about that."

This chapter examines urban placemaking and citizen planning among residents of gated colonies in Gurgaon, focusing on two of the most established and populous in the city, DLF's Phases I-IV and Unitech's Nirvana Country. Their housing and amenities were designed for a demographic of upwardly mobile, 
globalized middle-class households. The mainstream narrative of Gurgaon begins here. But the malls and commercial centers, gated communities and tech campuses that make up the visible image of Gurgaon's millennium city brand and reputation for wealth, exist alongside an equally well known and different reality. This one involves anxiety, feelings of disenfranchisement and disorientation that follow inhabitants (and visitors) through their negotiations of the city in everyday life. As residents moved to Gurgaon, during various phases of its urbanization, they set about acts of placemaking; establishing homes, careers, raising children, and finding and founding communities, whether property or value-based, to connect with and bring about various environmental, civil, social justice and beautification projects. As the broader challenges of Gurgaon's splintered and entangled urbanism interrupted or frustrated attempts at place-making, as described in this chapter, the true character of an anxious attachment to a new place comes into play, but also highlights the contradictions and role of place in self-definition among the Indian middle-classes.

Self-identity, including class-based identities, is one of the most basic units of a collective or community identity (Proshansky, H. M., Fabian, A. K. \& Kaminoff, R., 1983; Low, 1992). Place links an individual's self-concept to broader social identities associated with that place. Place acts as a medium that both contains and nurtures social interaction and a sense of belonging (Twigger- Ross, L. C., \& Uzzell, L.D., 1996). But threats to place activate a range of responses. Low (2004), used the phrase "place-protective behaviors" to describe the response to threats against attachment among residents of gated communities in the US. "The connection between a place and a person also resides in symbolic meanings of the landscape. When these symbols 
are threatened...place protective behaviors (such as fighting to combat changes) occur" (Low, 2004; p. 79). This type of behavior is not just about preserving place but is also about asserting one's identity to oneself and others through action. From negotiation to protest the participants in this chapter have engaged in activities that, by protecting place in a material sense, worked to establish a more secure vision and hold on place in a conceptual sense. Rather than leave, or disengage, the homeowners and renters portrayed here, much like the villager landowners discussed in the next chapter, have invested more (time, money, labor, emotional and intellectual energy, and social capital) into such places to shore up an initial promise of security and stability. These activities, what I've often referred to as the politics of place-making, encompass urban governance strategies, self-advocacy, political participation, activism, and citizen planning. The chapter focuses on collective action around urban citizenship and property-based governance among Gurgaon's RWAs and environmental organizations, whose activities often overlap. The focus on the environment, the locus for civic activism and engagement, reflects the extent to which physical planning problems and the risks of ecological hazard often coincide even in wealthy cities of the Global South. ${ }^{117}$ Gurgaon's urbanization trope, i.e. the neoliberal city or splintered urbanism of pixelated spaces and infrastructures characterized by extreme economic

${ }^{117}$ Common distinction between global "green" environmental agendas vs. local "brown" agendas. The latter are characterized as people-centric, particularly in poor or developmental contexts and urban areas, and look at the immediate dangers posed by things like poor sanitation, flood risk and other "environmental" hazards to socio-economically vulnerable human populations, as opposed to broader planetary or eco-systems focused environmental agendas. McGranahan, G., \& Satterthwaite, D. (2000). Environmental health or ecological sustainability: Reconciling the brown and green agendas in urban development. In P. C. ed., Sustainable Cities in Developing Countries. London: Earthscan. 
and social inequality, converges with the realities of third world urban governance. The loss of landscape via privatization, land use conversion, pollution and mismanagement of natural resources comes back to haunt everyone along the socioeconomic spectrum, not only the most vulnerable.

From a place-based perspective, residents and homeowners in Gurgaon's gated enclaves experience threats to attachment as threats to the symbolic reproduction of middle-class identity. These threats occur through place and the material; through the breakdown of public goods and services, encounters with the urban poor and environmental or ecological hazard that cannot be confined to the enclaved built environment, such as air pollution. Middle-class sensibilities, tastes, preferences, and identities are naturally heterogenous. The subset of middle-class participants in the research, living in DLF and Nirvana Country housing, may be understood to share a set of similar imaginaries, socio-natures or conceptual frames of what constitutes the city and the environment that fall within a certain range. ${ }^{118}$ They may live in enclaved spaces, but participants' sense of place tended to encompass a broader geography than residential space, or the neighborhood unit, and usually extended to the city more broadly. The city was understood not just as a space of everyday social practices, or as a market, but as a polis, with a civic unity that determined citizenship, and participated in a broader ecological shed than the visible footprint of the urbanized or built up areas of the city and district. This sense of place beyond the neighborhood, and a sense of the city beyond the city's limits, involved a broader spatial awareness, consciousness

\footnotetext{
${ }^{118}$ Baviskar, A. (2003). Between Violence and Desire: Space, Power and Identity in the Making of Metropolitan Delhi. Social Science Journal, 175, 89-98.
} 
and attachment to place, and inevitably brought issues beyond those facing an isolated gated community into the conversation.

From the beginning of fieldwork, even participants with the comforts and stability of adequate water and power supply, or clean residential streets outside their domicile were pushing to organize for improved service delivery, civic engagement, and sustainable urban development. While this awareness has galvanized one level of activism within gated colonies, among RWAs, there is another realm of activities and placemaking that takes on the city as a whole, or attempts to claim disused corners of it, such as the NGO I Am Gurgaon's Aravalli Biodiversity Park project, an ecological public space.

The rest of the chapter is outlined as follows. The next section discusses the middle-class imaginary of suburbia in Gurgaon as presented by participants, in relation to broader scholarship on this social cohort or set of cohorts. The third section takes these elements of class and individual identity further through the ways in which the scholarship on middle-class gating picks up the importance of place-protective behaviors. The fourth and fifth sections go deeper into these issues through the case studies of Nirvana country and DLF, fear and anxiety among their residents and RWAs over encroachments and environmental hazards. Sections six and seven move beyond the gates to explore broader conceptualizations of place, civic life and environment as well as attempts to address the challenges facing these conceptualizations through action among residents of gated colonies. 


\section{The Place that Was Promised: The Indian Middle-Class Suburban Imaginary}

Among middle-class homemakers interviewed, the most common reason cited for moving to Gurgaon in the early aughts (1990s onwards) was the desire for a suburban and/or more natural environment. This desire pointed to two important themes in participant residential histories: 1.) Residents described their choices by referencing experiences from childhood, i.e. visits to rural areas for vacation or school. 2.) Travels and exposure to or time spent in international locales, particularly in East and Southeast Asia. Almost all the participants in this group had traveled abroad. Many had studied abroad in Europe, and several had lived for extended periods of time abroad either in the US, Singapore, the Gulf states or East Asia.

When DLF's phases were first advertised, they appealed to residents seeking a suburban idyll partly constructed by the marketing and shaded in by projections of what suburbia represented to those who purchased homes (Searle, 2016). Participants repeatedly discussed the desire for a quiet residential street where their children could play unsupervised and for a more natural environment (with clean air) in proximity to the city. This image of a suburban landscape drew from various sources and past experiences, forming a new landscape out of a synthesis of urban and rural idioms. Much of this imaginary was about the material functioning of space in support of emotional and physical well-being, informed by a reenactment or reproduction of a place from one's past. The rural or suburban imaginary had a reciprocal imaginary of the proper city. A self-proclaimed Delhi girl, Amita was nostalgic for her days at a boarding school in the mountains, but also felt more comfortable in a hyper-urbanized 
and dense city like Hong Kong than in Delhi or in rural Haryana, only an hour's drive from where she grew up.

For years, DLF housing in Phase IV had sat on the boundary between rural and cosmopolitan, before the district began to rapidly urbanize. Lemanski's (2012) moral or ideological framing of the new middle-class makes sense of the imaginary explored here. Class encompasses its own cultural practices around consumption and living (lifestyle) as well as placemaking. These processes, of accumulation, affluence, and modern lifestyle attainment do not necessarily entail the rejection of Indianness for another set of values. Rather, they are more consistent with the ways in which postcolonial cultures are constituted through hybridities and occur at the interstices between foreign and archetypical ethnic or class identities, during a moment of tremendous cultural and economic transformation (Bhabha, 1994). ${ }^{119}$

Self-effacement or rejection of the idea of being "elite" was also frequent. Interviewees were quick to correct that while they were economically comfortable, they were not "rich". At times, participants also recognized in themselves certain aspects of elite status related to upbringing, education and worldliness. Discussions occasionally veered towards consumption, as well as certain kinds of abstention. They involved the minutiae of making decisions about products, picking and choosing within a marketplace of items and the ideas they represented. A pride of class came out of discernment or "sophistication". This meant different things to different people, but "responsible consumption" choices involved, for example, honoring traditional

${ }^{119}$ Bhabha, H. K. (1994). The location of culture. London: Routledge. 
Indian clothing by wearing kurtis, but making sure they were made through fair labor practices; throwing colors at Holi, but only all-natural ones rather than ones made from synthetic chemicals; eating organic food, improving the air quality of the city by promoting cycling paths, while helping the poor who did not have access to motorized transport. Many conversations about housing and planning would begin to address issues of socially responsible consumption, the notion of wellness or dismantling a zero-sum game by promoting a more holistic way of living or making some gestures to the inequities of urban living and privilege embedded in everyday life. ${ }^{120}$ While this notion of social responsibility and identity were tied, there also seemed to be boundaries on that identity and limits to its resilience in the face of outsiders. While a sense of place might have encompassed a broader geography than one's gated enclave, there was still tremendous unease with the idea of removing those walls and gates. The primary focus of place-protective behaviors was one's home and its immediate vicinity, the block, the street, the boundary wall. The long-term work of building a better city, and a better society were part of this project, but evoked less anxiety, and a sense of the long-term. These challenges were imminent but less urgent than protecting one's home.

\section{Place-Protection: Fear and Failure in Gated Colonies}

${ }^{120}$ The middle-class imaginary of wellness is not a new phenomenon. For example, late 19th and 20th century Germany had the idea of "life reform" or "lebensreform" in which emphasis on the body, health and self-improvement spawned an entire industry or lifestyle movement, that initially focused on internal environment "health" followed by external or "environment" from the 1920s-1930s. Unfortunately, these ideas were eventually co-opted by political parties and right-wing extremists. Fritzen, F. (2009). Changing the World with Müsli. German Research, 31 (3), 10. 
"If you're actually looking at the quality of the infrastructure the poverty around you, it's very hard to remain sensitive and remain functioning if you're truly seeing what's going on, right?"

$$
\text { -Organizer, "I Am }
$$

\section{Gurgaon”, 2016}

Over the course of fieldwork, I lived in a semi-gated plotted area called Sushant Lok, A Block. A block did not have official boundary walls or guards restricting access. Though originally developed by a company called Ansels, each of the homes or plots on this block were sold individually at different times to unrelated investors, some of whom built on the plot initially, others later. Some were owner occupied, but many were rentals, including my flat.

The block had villas and apartment buildings of different ages, at mixed densities. At the entrance of the block was a non-operational boom barrier. There was an RWA of sorts that discussed matters, primarily through WhatsApp. Conversations on the app began, for example, when a local construction crew cut the cables while installing a drainage ditch that took internet access away from residents for almost a week, or when the road flooded during monsoon.

Part of the block was skirted by the boundary wall for a gated colony called The Ivy. From a first-floor apartment on Sushant Lok A block, the tops of the white condos of The Ivy cast shadows over the road. During Diwali, one could see (and then hear the echo of) Ivy residents lighting sparklers and crackers from balconies across and above the way. They were not our neighbors, technically, at least not by the logics of our housing arrangements.

Many of the workers, and domestic staff employed in The Ivy, lived in nearby 
Chakkarpur Village, which had a large concentration of Bihari and West Bengali migrants. A suggestion had been made to cut a doorway for them into the boundary wall of The Ivy to allow a faster route, particularly for women who would stay late in the evening to help with cooking and cleanup but needed a safe journey home in the dark. While A block seemed like a conduit for safe passage from inside The Ivy, the residents of A block regarded this potential fissure in the boundary wall with apprehension. It would bring unknown people to the block in the dark. The WhatsApp group scrambled for a solution and decided to intervene before the doorway could be cut. In Indian cities, the practice of "god tiles" involves placing ceramic tiles with Hindu deities on building walls to deter vandalism and public urination. ${ }^{121}$ Going a step further, the A block RWA built a "wayward shrine" along the exterior of The Ivy's boundary wall where the intended gate/access point would have been cut. With the new and sacred meaning of the wall now established, it could no longer be used as a point of entry or exit.

${ }^{121}$ Larios, B. and Voix, R. (2018). Introduction. Wayside Shrines in India: An Everyday Defiant Religiosity. South Asia Multidisciplinary Academic Journal. Association pour la recherche sur l'Asie du Sud. 


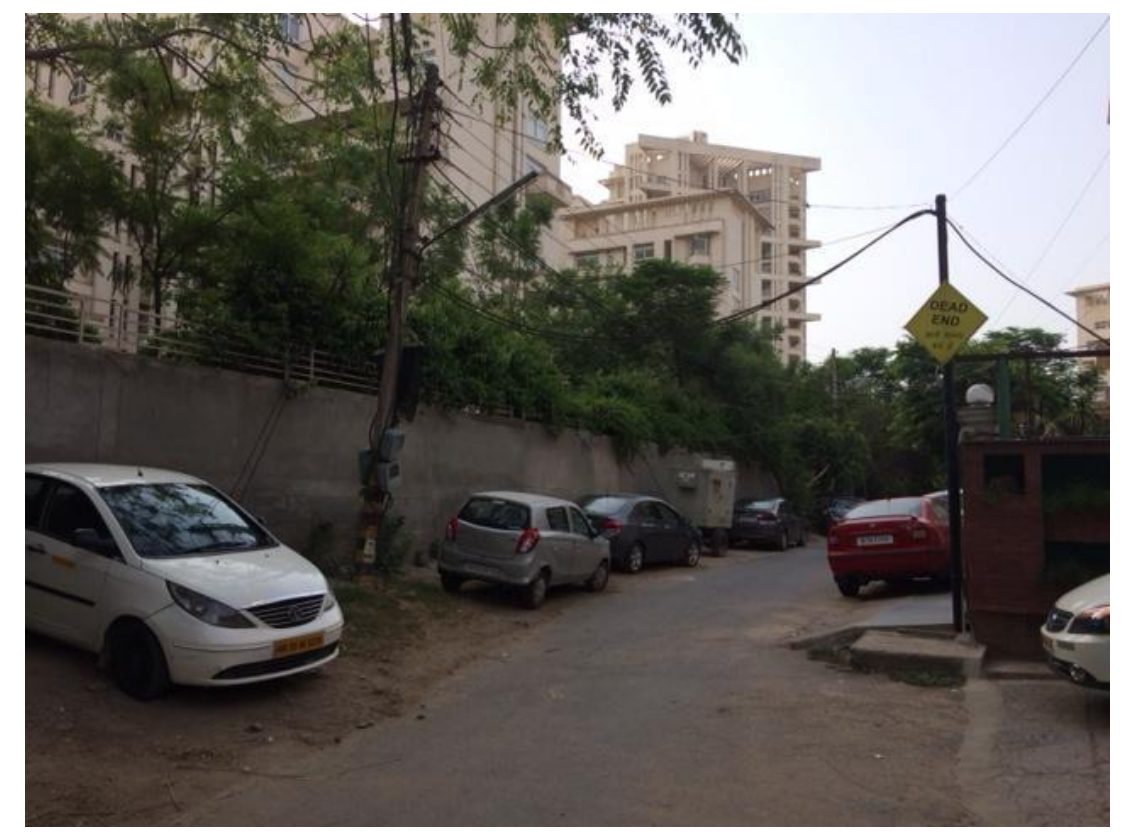

Figure 6: Boundary wall between the Ivy (left), and Sushant Lok A Block.

The previous section began to explore the middle-class imaginary and placebased identity around suburbia and the garden city, as a reconciliation of values and the balance of urban and rural, through housing and curated landscape. Always in tension was the anxiety raised by immediate threats to place, as well as aspirations for a broader urban unity and coherence between discrete urban spaces. Conflicts over gating and security always hinted at this tension, both the desire to protect what was within, as well as fear of the disorder on the other side, beyond one's control. Ironically, the residents of Sushant Lok A Block were just as afraid of the unknown humans of a posh gated community as the residents of The Ivy were of the greater city (hence the walls to begin with). Throughout the research, gating referred to housing developments that were enclosed spatially or securitized and closed to public access. However, as described in the above episode, not all housing is built with gates or walls. Occasionally, these features were added later. Often, an RWA might add some 
type of gate or boom barrier later to restrict access to its jurisdiction, as is predominantly the case with DLF plotted housing colonies. For walled colonies, such as The Ivy and Nirvana Country, discussed in the next section, one entered through a gate house and interacted with chowkidars or guards, presented some form of identification and/or reason for being on the premises. Such communities ranged from upscale developments (large suburban detached homes, often with community facilities and other club goods), to middle-income apartment complexes, which may or may not have a unifying housing society or RWA.

The act of gating off a settlement or complex of buildings is as old as walls themselves. In the US, more than half of new housing construction takes the form of suburban gated communities or Common Interest Developments (CIDs), in which residents collectively pay into private service provision or club goods, often while opting out of public goods (Warner, 2011). ${ }^{122}$ The enclosed or gated community has become so pervasive as a model for building new housing across the Global South, that a debate has emerged on whether they should even be considered a predominantly Western or Global North model of decentralized urban consumption (Leaf, 1994).

With each context, an altered set of desires or expectations and set of economic or political influences come into play. In late-socialist China, for example, the rise of gated housing among the emerging middle-classes highlighted the ways in which public-private redevelopment projects could fundamentally alter the urban landscape

${ }^{122}$ Many criticize such communities for exacerbating inequalities and fracturing the urban environment. They invariably provide tax benefits to their host municipalities, while reducing the burden on public resources. Despite their supposed economic benefits, they have also been accused of being economically unsustainable, and of siphoning off certain public goods, such as access to land, water and other resources (Le Goix, 2005). 
in contrast to the previous danwei system that united domestic and professional life in one location. Zhang (2008) wrote about the loneliness and break down of past social support systems among middle-class Chinese residents of gated communities. In postsocialist Bulgaria, gating allowed residents to achieve a level of privacy and separation as well as visually display new wealth in ways that were heavily restricted under communism (Hirt, 2012). ${ }^{123}$ In Brazil and post-apartheid Johannesburg, gating provides a modicum of security while reinforcing patterns of socioeconomic and racial segregation (Caldeira, 2000; Murray, 2011). Low (2004) wrote about fear and perceptions of safety among residents of gated communities in the US. Similarly, in Gurgaon, residents and RWA organizers often spoke of biometric identification and the necessity of keeping undesirable people out.

In the contemporary Indian city, the introduction of suburbanized or discrete "islands" of wealth or security, also delve into the politics of formal and informal planning. Pre-planned, gated communities are the "rational" or legitimate forms of spatial planning, with established or legal tenure claims (although there are exceptions). However, this formal space is always entangled, to some degree, with informal spaces outside the gates (Srivastava, 2015). One of the most striking uses of gating in this context also appears to be rhetorical, as a way of establishing the aesthetic legitimacy of an urban space in contrast to the informal just beyond the wall. As design features, walls help developers provide a clean break with external contexts, to engage in visual storytelling and "place myths" of success, safety or a clean

${ }^{123}$ Hirt, S. A. (2012). Iron Curtains: Gates, Suburbs and Privatization of Space in the Postsocialist City. London: Wiley-Blackwell. 
environment for potential buyers and distinguish themselves among several builders offering similar curated landscapes (Chacko, 2009).

Walls often create the illusion of separation, or a binary between a space of value and a space without value, between the good nature (lawns, parks, and plantings that are watered and cared for) and the non-nature (whatever remains of the indigenous landscape after years of construction and human activity or neglect). The participants in the research discussed and offered up the problems with binary thinking about walls. Through their residential histories, they described various confrontations with the wall, coping strategies, or failure to comply with these barriers or ignore the distressing aspects of an urban environment beyond them (a few of the participants were thought of as troublesome or "renegades" in their RWAs). The argument they often put forth was a simple one: walls aren't enough. As technological interventions, they are often shoddily made and easy to scale, and do not control broader ecological hazards, such as air pollution, one of the biggest concerns in Gurgaon besides sanitation. As urban pacifiers that block disturbing scenes outside the colony, walls are also temporary blinders, that serve this purpose in the evening, as most residents work outside gated colonies and must leave them to shop or conduct errands. If one lives in a high-rise, the view from a second-floor apartment starts to foreshorten the walls, until they flatten into the landscape beyond them. As the above moment of conflict between two adjacent affluent communities illustrates, walls create liminal spaces beyond, that may or may not have value to others. Trash can be thrown over walls, but one person's dumping ground or short cut home could be another person's front doorstep, and so the wall, which has multiple sides, never serves one function as a 
piece of material and symbolic infrastructure.

The purpose of the wall in Gurgaon was never restricted solely to the protection of private property. Because of the civic and semi-public nature of gated communities, the spaces that were walled off were typically designed as open spaces or spaces of leisure for members of the community, places in which to walk at night, park one's car, play outdoors, host celebrations and so on. Gated colonies were not just residential spaces, but also public and commercial ones, with club houses, restaurants, shops, schools, and sometimes their own firehouses. The restrictions on who could enter the gated colony were a statement about the kind of public space that residents wished to experience, in which neighbors from adjacent informal settlements and urban villages might be present as workers, gardeners, dog walkers and trash collectors, but never as private citizens on their day off. The public space of the gated colony was free of visual reminders of what leisure and home life looked like in the slum. Some of the anxiety about leaving the gated colony was grounded in the credible threat of violence, theft, harassment, pollution, and encounters with filth or dangerous roads. Residents spoke highly of their homes, of the material comfort at home, but also expressed fear about leaving home and negotiating the space beyond it. The fear of space was not just in terms of nuisance, or aesthetic unpleasantness, such as seeing trash, a construction site, or a depleted water body, but the fear of people themselves, particularly the poor.

Many of the city's formal public spaces were also premium access or commercial spaces with security and metal detectors that limited entrance to paying guests. Ad hoc and free public spaces were plentiful despite this. The dead space of 
"unused" sidewalks that continued for kilometers without pedestrians would become markets for small vendors and repairmen. Undeveloped plots with large "coming soon" billboards for luxury housing, became sites for open defecation, trash dumping/burning, winter bonfires (when the temperature dropped), gardens, or sites for other activities that could not take place in the residential lanes of the urban village slum. The vegetated highway median between Sushant Lok and a posh outdoor market, with an international supermarket, a Starbucks and an Indian-French fusion patisserie, became a perfect grove for pigs to graze. Shaded areas beneath flyovers and elevated train lines became a place for day laborers to gather for temporary work, or auto-wallas to park for an afternoon nap before the return of commuters from Delhi. The streets of the city were full of activity, repurposed spaces of suburban living (bike lanes, brick sidewalks, road medians) occupied by invisible actors, primarily migrant workers, making place.

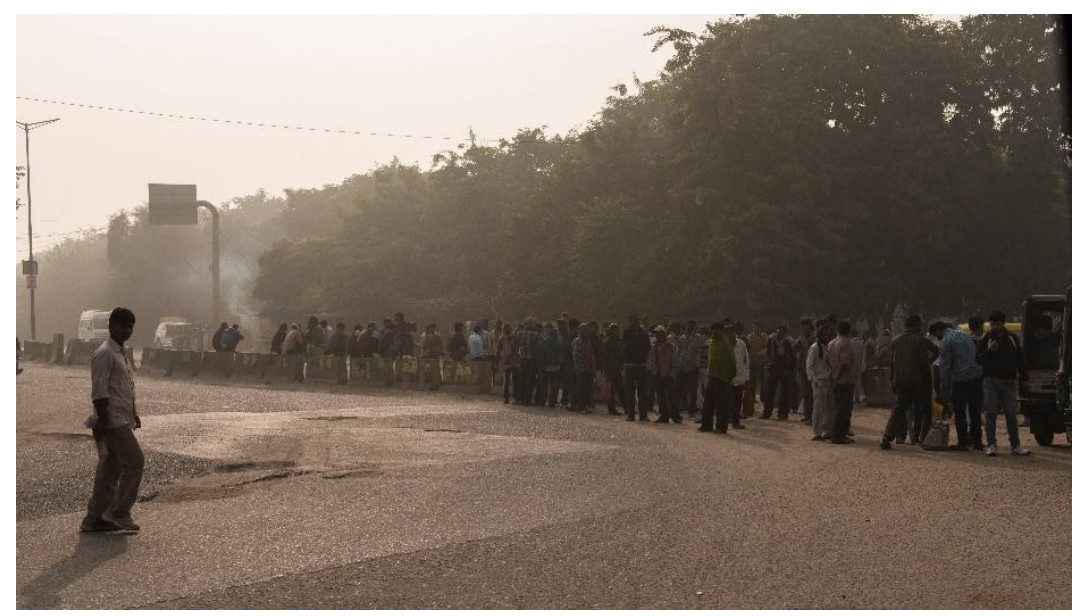

Figure 7: Day laborers waiting for contractors to arrive and recruit.

Visceral responses of disgust or aversion to these improvised public spaces beyond the walls echo, to some extent, colonial accounts of Indian markets and 
mohallas, the "traditional" public spaces, often described as disorderly. Ironically, this perceived chaos was explained by the ways in which the bazaar might function as an extension of the home. Chakrabarty (1992) argues Western and Indian stereotypes about the filth of the bazaar were rooted in the prevailing conceptual boundaries between public and private space, and the perception that Indian societies and cultures could not police these boundaries or abide by the proper vs. improper use of space beyond the domestic realm. ${ }^{124}$ But filth itself is often a social construct, a way of identifying 'matter out of place' (Douglas, 2003). ${ }^{125}$ While the rhetoric of urban planning and humanitarian development have come down on dirt, trash, and open defecation as uncomplicated evils of material reproduction, with obvious risks to health and well-being, the politics of trash, waste, and shit, always speak to issues of symbolic reproduction and the affective threat of "matter out of place" (Doron \& Raja, $2015) .{ }^{126}$

Chakrabarty (1992) points out "While this way of seeing is no longer exclusively European, its main bearers in 19th century India were no doubt the Europeans themselves whose modernist categories of 'public' and 'private' were constantly challenged by the ways Indians used open space. The Indian street presented, as it were, a total confusion of the 'private' and the 'public' in the many

\footnotetext{
124 Chakrabarty, D. (1992). Of Garbage, Modernity and the Citizen's Gaze. Economic and Political Weekly, 27(10/11), 541-547.

${ }^{125}$ Douglas, M. (2003). Purity and danger: an analysis of the concept of pollution and taboo. London: Routledge.

${ }^{126}$ Doron, A. \& Raja, I. (2015). The cultural politics of shit: class, gender and public space in India. Postcolonial Studies, 18(2),189-207.
} 
different uses to which it was put. People washed, changed, slept and even urinated and defecated out in the open" (p. 541). ${ }^{127}$

In the next section, a research participant describes her dealings with a wall and attempts to ignore its breakdowns in the face of various material hazards that threaten meaning, bodily well-being, family, and property. Her experience was one of many accounts among participants who had substantial experience living in and acculturation to cities in India and abroad. Their stories demonstrate the ways in which the violation of individual boundaries coincide with the violation of place boundaries.

\section{The Boundary Wall: Defending Nirvana}

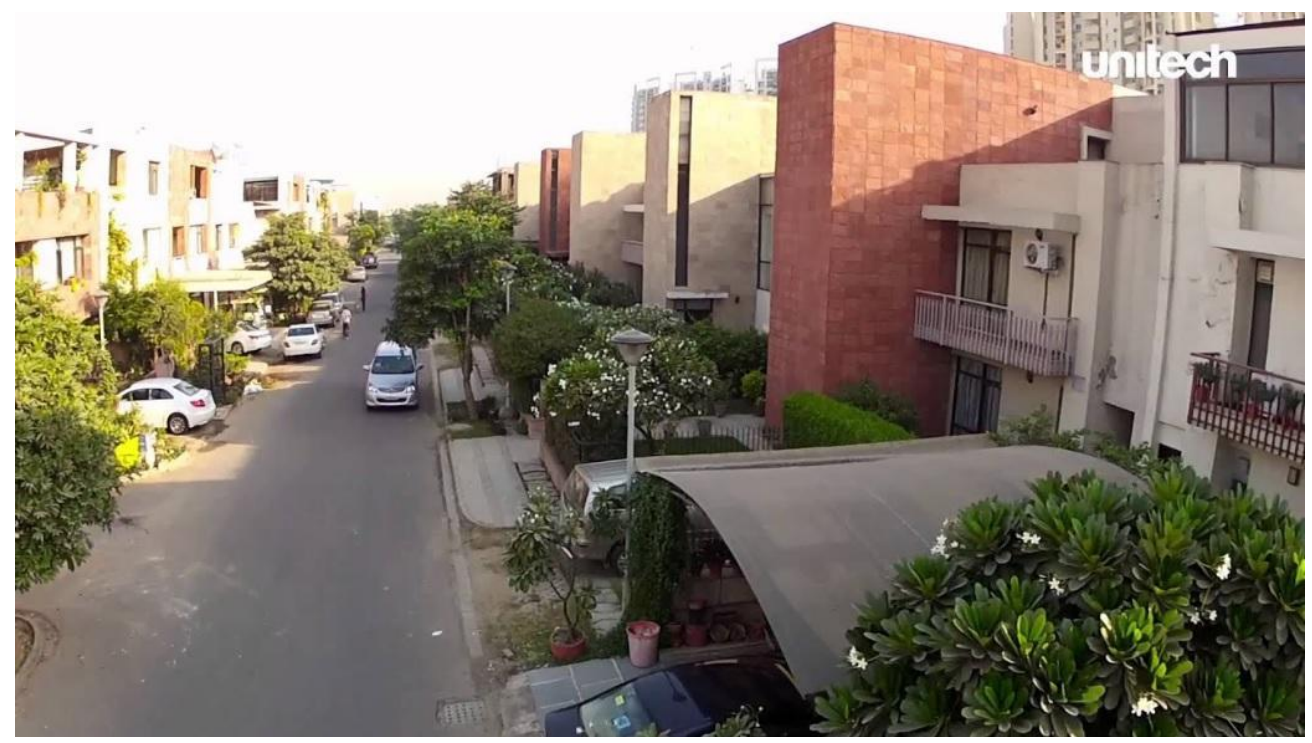

Figure 8: Drone footage inside Unitech's Nirvana Country, Espace Colony

Over the past seven years, Romila had kept her eye on a pile of construction waste beyond Nirvana Country's boundary wall, spread across 2 acres of kabsa

${ }^{127}$ In the early 20th century, urban sociologists argued that continuous exposure to scenes of urban disorder eventually desensitizes the observer, who adopts a kind of "blindness" in order to navigate the street unaffected. Simmel, G. (1903). The metropolis and mental life. 
land. ${ }^{128}$ The waste accumulated gradually, until a plateau of about 8 feet had begun to appear. Upon investigation, she discovered that some of the land belonged to HUDA, some of it to a local villager. The rest was unclaimed common land, under court petition. Nonetheless, a builder was already developing the land. There would be a set of 10,000 flats. The waste was not in the primary construction location but had been dumped there by a contractor with a retainer of 4,000 lakhs.

At first, the mound presented an eyesore. She did not like the way it looked. But then it grew. Waste seemed to attract more waste. Household and other forms of everyday trash began to accumulate among the concrete and rebar debris. There was an odor, and eventually small trash fires were lit there. This continued for several years, smoke billowing indiscriminately into Nirvana from the trash mound, albeit sometimes the smoke originated from trash burning within the colony. A few years back, one of her neighbors had renovated their home. The workers burned debris that contained copper wires to keep themselves warm. Romila's eyes burned and her daughter vomited. She reported it to the RWA. "They said show us the law. I said, ok, here is the law. They said ok, but who will do anything about it?"

${ }^{128}$ Nirvana's developer Unitech, is the second largest operator in Gurgaon, after DLF. Unitech is among India's largest real estate firms, founded in the early 1970 s by a selfdescribed "group of technocrats", Ramesh Chandra, Dr. S. P. Shrivastava, Dr. P K Mohanti, Dr. Ramesh Kapur and Dr. Bahri, all civil engineers. As of Feb 2018, the National Company Law Tribunal had suspended Unitech's directors over allegations of fraud and embezzlement. One of Unitech's largest projects in Gurgaon is Nirvana Country, spread across 300 acres, a 20-30-minute drive southwest of central Gurgaon. The developer describes the colony as "one of the prides and joys of the City of Gurgaon, with over 4000 highly elite families already residing within the borders of [its] serene location." Units in most of Nirvana's apartment complexes are at least one crore, while a house or villa is at least 2.5 crore. The colony offers parks and safe play areas, as well as a clubhouse. Unitech Group, retrieved from http://www.unitechgroup.com/us/townships/nirvana-country-gurgaon.asp 
Three robberies had taken place in Nirvana since the trash mound reached its zenith. "Literally they've jumped in." This seemed to have been the final impetus for action. The waste was no longer dumped within the community or its immediate vicinity, but was instead taken across the road, to a vacant HUDA plot, deposited in what had served as a stormwater drain. Romila attempted to document and report what was happening to the MCG, who requested a photograph.

"I said, do you think mad is written on my face, why would I do that? Is my life not important to me?" She went to the District Commissioner with the violation, compelling the Haryana state pollution board to act. "So, he says "capacities. We don't' have capacities," That's the excuse the civil administration will give you. We do not have capacities. We are building capacities."

Government actors argued that it was the RWA's responsibility to remove and dump the waste. When Romila moved into Nirvana Country, more than 15 years ago, it seemed to her and her husband like "wilderness". Over time, she witnessed the disparities between the first wave of homebuyers (when the costs were lower) and more recent, and more affluent, homeowners. The wealthier households, seemed to take a different approach to the community than long-time, but (slightly) less affluent households.

"The people who can afford much more want to pay higher facility management services and people who cannot they want to roll up their sleeves and actually get down to volunteer time to work... community conscious...So even when you have a place like Nirvana, you've got people from different economic profiles...but that doesn't bring about a sense of community, in India." 
She continued, "and by community in India, my understanding is it's not territorial. It's very much an internal understanding of where I belong. Do I belong to a Brahmin creed or do I belong to a Tamilian Brahmin?"

The differentiated sense of community among members of the same common interest development was telling. Romila distinguished between members of different communities who associated a sense of belonging, using a place referent word like "where" with a group of people rather than a specific territory (although even in this abstraction she could not avoid reference to a specific regional or Tamilian identity). Rather than diminishing the significance of place, however, this definition highlighted the importance of place and attachment to it, its meaning and value, as the root of conflict between members of different communities taking collective action as one common pool. The assumption of heterogeneous needs, desires, place values (and ability to pay) among an assumed-to-be homogenous group within the gated colony could lead to internal conflicts as those differences led to different interpretations of what ought to be (what plants should be planted, how money should be spent on aesthetic improvements, where schools should be placed in relation to residential spaces and so on). As the conversation continued, Romila began to reflect on and dissect her initial statements about the a-territorial nature of community in India and suggest a few counter examples such as Old Gurgaon. The strip of housing and storefronts, and the bus station on Old Delhi road, appeared denser as an urban enclave of sorts, in which the wealthy, and the less so, seemed thrown together in neighborly interactions not predicated on servant/employer or patronage relationships. 
"You've got somebody who has three cars also neighbors with somebody who is driving a scooter, who will also come out with his evening cup of tea, speak to each other, and there's a third person who may be a shop owner, and there's a fourth person who is working in the corporate office, so it's a little bit more heterogeneous, integrated."

She had worked with her RWA on water issues, specifically sewage treatment, which the RWA had raised money for. Water consumption had begun to far exceed the allotted 500 liters per person per day. She would watch the horticultural and gardening teams operate in her community, using potable government water on landscaping until "every little blade of grass would bless me that, oh I've been washed." The waste of water and the contamination or depletion of water bodies was a common source of tension among residents at RWA meetings and online.

"We've had ferocious arguments on the e-group, and I actually walked out of that because the email group for these 1,000 families who 200 members and typically 30-40 are very active, it gets ferocious, you can have a debate on anything and you will not have a consensus."

While using groundwater for construction purposes is a punishable offense, the practice is common, one that Romila had reported to local authorities to the embarrassment of her neighbors. "I've had my own RWA come up to me and say why don't you just coexist peacefully, how does it matter... personally, I am sick of hearing it doesn't matter." She believed that the incapacity of local or state government had become a convenient excuse for inaction.

"You have an alibi...the politicians are no good." Inaction, to her mind, came from place detachment. "We are just coming here to earn. We've got our factories running over here, we're going to be using your waters and we'll go back down to Kerala and we'll be safe." 
Something had shifted for her since moving to Nirvana. She was unable to ignore or look the other way at things that others seemed to easily unsee. It was not just the politicians and her neighbors or the builders dumping waste or depletion of the water table. In the evenings in Nirvana, she would sit outside and watch the servants walking the family dogs, leaving their feces on the well-watered lawns. If you complained, they might shrug and say it was the sweeper's job. She had begun to observe her own gardener in his morning ritual. He would bring his tea in a small knotted plastic bag. After he drank the tea, he would toss the empty bag into the flower beds as he worked on them. She had bought him a thermos, but he never used it.

The presence of plastic waste, wrappers, and water bottles had started to become a kind of open defecation for her. She understood this casual indifference to trash, in the context of a hierarchical system, where cleaning was historically and presently a role for people at the bottom. But observing the reproduction of this social order or the assumption of it in the daily casual littering, had started to unnerve her. Even though she employed domestic help, and constantly managed hierarchical boundaries, the dropped litter, the burning fires and the smoke that seemed to touch everything at once, presented a visceral reminder that Nirvana was a place on earth, in India, deeply linked to the reproduction of a hierarchical social order rather than an escape from it. It wasn't blindness that made people litter, she reflected. As Doron and Raja (2015) argue "filth endured in public spaces... has less to do with a certain class of people's 'refusal to become citizens of an ideal, bourgeois order', than it has to do 
with the neglect of spaces people share with those beneath them in the caste hierarchy."

Garbage is someone else's problem. By making it her own, by letting her neighbors see how much it bothered her, she had also challenged a norm. She believed she had become the nuisance in doing so. To see the indifference not only for the dog walkers, but among many of the more affluent households in her RWA, highlighted the differentiated nature of middle-class identity, place and the place protective behaviors they encompassed, including environmental consciousness. There were different ways of taking care of place, of protecting it, or failing to. As the conversation shifted, she observed that governments reproduced this way of thinking about trash, subcontracting the saf karna to communities and eventually RWAs, occasionally taking it on as a performative, but exceptional gesture. RWAs were now senior-sweepers, overseeing micro economies of waste management and collection from behind the gates. They presented a quasi-governmental interface between the state and the individual, the mechanism by which individuals exercised their rights to property, but also self-determination through placemaking and its protection. 


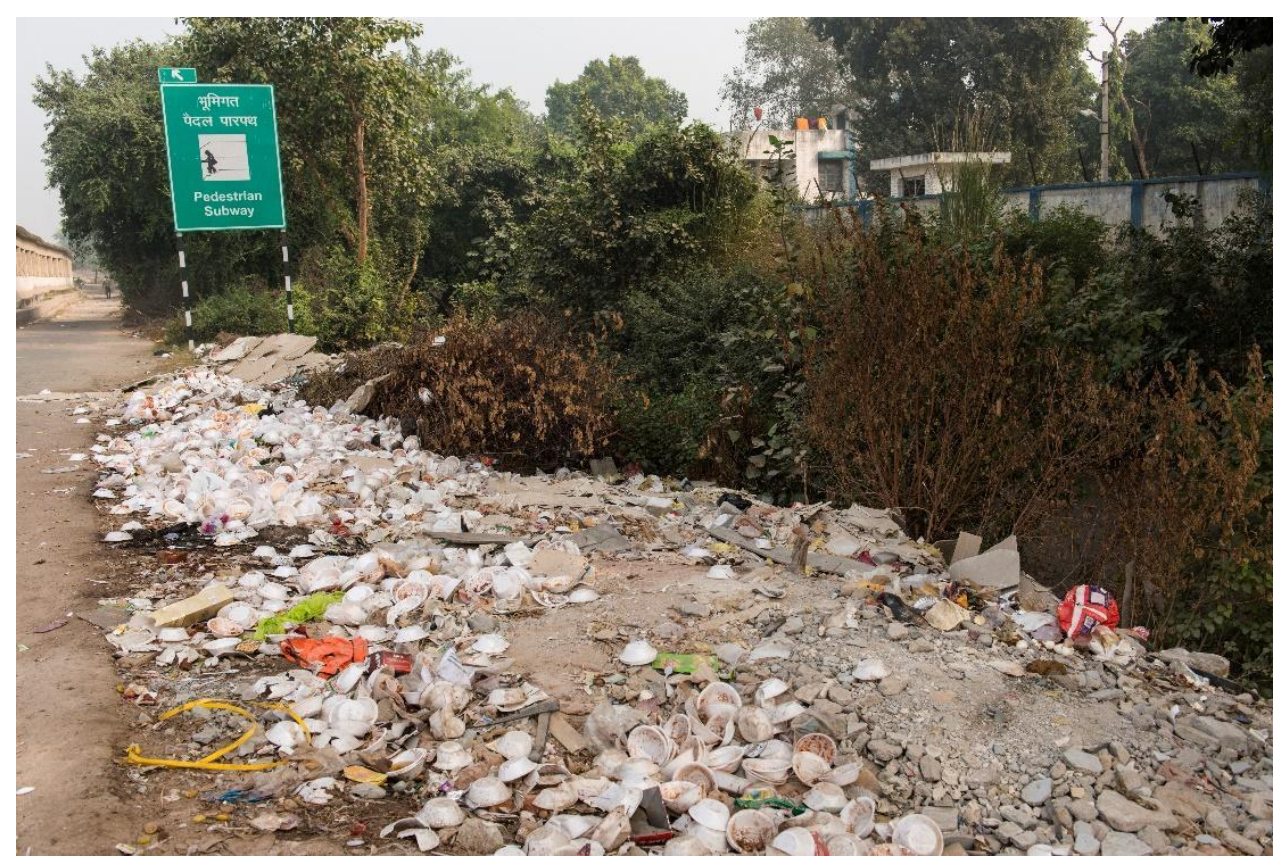

Figure 9: Footpath outside a gated colony.

\section{A Tale of Two RWAs}

"On the bus in India, the driver has a conductor. The conductor has a helper. The helper has a sub-helper. The sub-helper has his munbo. Everybody, there's somebody who is lesser who you can engage to do your work...To my mind, RWAs are the first building blocks for a city."

-Romila, Interview, 2015

I met the head of the Nirvana Country's RWA, Sanjay, at a club in a subdivision of Nirvana called Espace Colony (the French word for space, locally pronounced "e-space", as in email). The club was on a site that Nirvana's builder had originally reserved for a community center. "They are bound to make a community center," he said. "If I come in, I have to pay for everything at commercial rates, like a five-star hotel." This was apparently illegal. A different site had been selected for a community center but stood vacant. It would have been the last task of the developer to build on that empty plot before taking a completion certificate, Sanjay said. 
Nirvana Country's builder, Unitech, was one of DLF's chief competitors in Gurgaon. The RWA had been after Unitech for 3-4 years, trying to take over the provision of non-mandatory services. Each household paid a membership fee. The flat 1000 Rs per month subscription, also funded the 13-14 employees who ran its administration. The fee was decided by the general body and might be used towards maintenance tasks, such as keeping a plumber or electrician the RWA rolls, who could be called in for free services by member households. External issues, lighting in the complex and other forms of maintenance beyond the property were typically met by Unitech. ${ }^{129}$

The system was not working, however. The builder was meant to be a temporary guardian for the colony until the RWA or MCG might take over, but Unitech had never sought a certificate of completion, and had stayed on to extract revenues through the club house and high maintenance fees (while the contractors were subpar). The work and vision of the RWA was undermined and often in direct conflict with the developer's agenda.

"We decided...we had had enough. Nirvana is one of the most beautiful colonies developed in Gurgaon and it has the potential to be "the place to live." Most of the people who are living here are from Delhi. We mostly picked it because it is

${ }^{129}$ The breakdown of housing was $65 \%$ ownership, $35 \%$ rental, of which 850 to 1000 were occupied ( 800 plus 550 would be owners). The rest are were bare plots. Those who were not owners could not participate in the RWA by law, according to the societies act. Realizing the downside to this, the RWA offered open houses to involve both tenants and owners in decision making. "We don't distinguish, everyone comes discusses resident issues, we answer. The house must pay. And if it is the tenant that pays, whatever according to the agreement the landlord and the tenant. For us, we bill it to villa number 281." Sanjay noted this tended to vary by owner, and the individual arrangements between tenants and landlords, i.e. who would pay which aspect of maintenance or RWA dues. The ownership of many of the vacant plots was unknown. Double taxation, an issue also mentioned in the DLF case was less of an issue for Nirvana. 
away from the capital. For some peace, better facilities, better security, not for a place where we are fighting for our basic rights."

To make their case, the RWA referred to the Haryana Development and Regulation of Urban Areas Act of 1975. Its original intention was to protect property owners from negligent developers, eager to abscond without maintaining their projects. This "leaving the colony in the lurch" also protected local governments from assuming maintenance duties in the absence of the developer.

Since the 1950s, India's RWAs (subscription-based housing societies) have become some of the most powerful actors in urban self-governance. ${ }^{130}$ The rise of RWAs, as vehicles for democracy and citizen planning, has coincided with a slow process of decentralization in urban government, alongside the emergence of a more globalized and elite middle-class in the post-liberalization period. They work primarily to secure or maintain services and infrastructure, often relying on personal connections or clientelist relationships, petitions, demonstrations, the courts and the media to bend local governments to their causes (Lemanski, 2012). In some ways, RWAs function as a form of network governance, supplementing the standard procedural aspects of elected democracy (Pierre, 2009; Goldstein, 2016). From a State's-eye view, a good RWA is one that solves its own problems. Yet, these organizations act in dialogue and often argument with the state.

${ }^{130}$ Nirvana's RWA was registered under Haryana's Societies Act. Under Haryana law, colonies with RWAs exceeding 300 members adopt a collegiate structure. At the top of the RWA is an Executive Committee, which takes financial approvals from the general body. At the time of research, Nirvana county had 117-118 collegium members, since there were still vacant properties in the colony. Nirvana country had 1,200 households, in which one member of each household would have voting rights. Each household would have the same representation, no matter its size. Every 10 households had a representative, with a maximum number of 127 collegium members. 
Since the 1990s, scholars have observed a rise in middle-class urban activism fueled by or perhaps ramping up the activities of RWAs (Chatterjee, 2004). Ghertner (2013) argues that while there is nothing new about elites aligning themselves with bureaucracies tasked with the enforcement of order and progress in urban space, the so-called "new middle-class" is not just a socio-economic category, or a self-made ideological or normative position (the "moral middle-class"), but is constructed by the state itself. The demography of Indian cities has not simply become, as Chatterjee phrased it "bourgeois at last." Rather, there has been an ongoing, and deliberate gentrification of state space with the rise of neoliberalism. Schemes like Delhi's Bhagidari, designed to give RWAs privileged access to planning bureaucracies, seem like a reward for legal tenure and world class aesthetics (Ghertner, 2011). RWA participation is often characterized as honorable or part of the order of things, as opposed to the rebellious insurgence of the poor, "[T]hus, the ties that link India's elite to upper level bureaucrats and policymakers are not just ones of economic stature and influence; they are also based on shared cultural formation and positionality" (Ghertner, 2013). RWAs become integral not only in terms of their independence, but because they are taken seriously as sources of knowledge production and governance expertise can influence problem definition in planning, as they communicate directly with the authorities, as well as decide the moment when a problem is adequately solved (Lemanski, 2012).

RWAs are not just entangled in a relationship with the state. They are in many ways interlocutors, or "the voice of the community", calling the state and the private sector out on corruption, abuses of power and exploitation. As consumer citizens, they 
are the children of both democratic processes of the state, and the customer driven ethos of the private sector. In 1975, when the Housing Societies Act was passed, state governments were responsible for providing mandatory services to group housing colonies (electricity, water, roads, and some waste disposal). In present day Gurgaon, developers provide additional services, such as security, power and water backup, solid waste management and so on, referred to as "non-mandatory services".

In cities like Delhi, where the housing stock is often much older, and private group housing development is restricted, the original developer does not necessarily have an ongoing relationship with the RWA or play any role in service provision. In Gurgaon, however, colonies built in the past 30 years have typically maintained relationships with their developers, some of which are still managing the maintenance and provision of additional services, at a cost. While the Haryana Societies Act requires developers to maintain projects for five years after receiving a completion certificate, such certificates are rarely taken. Developers often find ways to continue their commercial activities in group housing colonies indefinitely. As Sanjay observed, this process has given developers the benefit of the doubt and rewarded those who postpone project completion. "So, what does a person do? They develop a colony. Let's say initially 200 acres. They sell it off. People start to live in it. They don't take a completion. They take a partial completion. I buy 20 acres of land, merge into it, and make it part of this community."

One could argue that bureaucratic red tape is to blame for this kind of developer hovering and exploitation. While there is a provision in the law that allows for an extension when a developer has been unable to complete a project on time, the 
process of getting that initial license is onerous and requires an assemblage of a minimum 100 acres to qualify. Once a completion certificate is taken, colonies cannot be expanded, which creates an incentive for developers to linger over an existing project for decades rather than repeat the process of acquisition and licensure to break ground elsewhere.

In 2014, Nirvana Country's RWA decided to end their relationship with Unitech and take control of non-mandatory service provision. "The moment you take over nonmandatory you have control over the complex." They filed a resolution and approached the Gurgaon administration and with a formal complaint.

"We put our case in the grievances...with the Chief Minister, appointed a union minister to look into it, and the entire administrative set up is there...It's like a court where you have the DC minister heading it the deputy commissioner of Gurgaon. He's an IAS officer and everyone, (the HUDA commissioner). There were around 17-18 people on the dais. Then our complaint was taken up there."

At this point, Sanjay had taken on the full-time responsibility of studying the law around the grievance. "I was in one government office or the other digging out rules digging out articles in the act, fighting with them, arguing with these people...The point that we took was article 21 of the Indian constitution. There is a fundamental right that I decide what I want."

The RWA was frustrated with the legal advice they received and decided to represent themselves. By the time the RWA took the case to the State High Court, it was, in his words, "watertight". "You are basically arguing for your fundamental right, article 21 of the Indian Constitution. No one actually supersedes the Indian Constitution...period." Much to their surprise, the administration was receptive to their 
claims, establishing a model for such grievances still in practice. Both sides gave their arguments and a committee was set up to generate a report for the Deputy

Commissioner.

"They worked on it, they talked to us. They talked to the builder and they submitted a report. It happened really quickly. Nobody believes that work can happen fast in the government machine. The committee gave its report in two days. And the day the report was given that was the day the Deputy Commissioner ${ }^{131}$ passed the orders that the RWA has the right to take over these services and the fundamental purpose of this act was to protect the buyers not the developer."

The RWA succeeded in getting a government order allowing the society to take over mandatory and nonmandatory services. Some believed this would set a new precedent. Other RWAs began to approach Nirvana Country asking for advice on how to take similar action. "Every five or six days. I have become a consultant to every RWA," Sanjay said.

Once the developer was ousted, management of services started to fall apart in a sloppy transition. Eventually a US company, CBRE, was hired to handle facilities. The RWA had collected 1000 Rs a month over a period of five years, while spending $300-400$ rupees a month, so that when the changeover occurred, there was a balance to run the colony. Among the RWA's accomplishments, Sanjay noted, it was the first to sign up with the power grid corporation of India, and had begun installing solar panels, hoping to use net metering, and sell excess power to the grid. The RWA was also relying on groundwater and municipally supplied water for horticulture and was ready to invest in a sewage treatment plant. They had approached the administration

131 Sanjay described the DC as “a dynamic person. Upright, honest to the teeth. You can't ride that man..." 
for land to use (at a cost of 15 crore) in exchange for building the plant that would handle green waste recycling, composting, and solid waste management using RWA funds. The RWA President had managed to convince an international company to build a plant worth 1.25 crores free of cost, offering to pay the customs duty and $30 \%$ of the cost with an international company, arguing the plant could be used as a showcase.

"This is what an RWA should do...you should have the collective powers to tell a company, ok guys, you are a big 6.5-billion-dollar company...you can use it as a demonstration plant." The RWA also had plans to develop a natural gas pipeline, offer free Wi-Fi for the colony, and create ID passes for roughly 3,000 domestic help, drivers, guards and other staff using biometric machines.

Sanjay had spent his weekends for the past four months on RWA work, despite his family's complaints. "I know at this stage I have to show the way...I have a vision for it...So I guess the impact or the success of an RWA really depends on the leadership...and people have to respect that person...I've been happy to build that respect...I hate paperwork, but I am good at taking decisions, I am good at planning and discussing and finalizing." Nonetheless, the disputes within the RWA were often contentious. There was in-fighting, resignations, and disloyalties in the politics of RWA government. The RWA President threatened to resign on several occasions. While Sanjay had faced some direct opposition to his leadership, he characterized it as a minority of RWA members. Failure, as he saw it, was inevitable. "We will falter. We will fail. It will not be $100 \%$. We will waste money, we will lose money, we agree to the project it will cost money. We will pay, but for the fear of failing, we want to 
not do anything?" In a particularly tense moment, the RWA intervened in the issue of a school location. Several plots had been set aside for schools, a legal requirement for the developer. Developers would often find irregular plots to meet these requirements that would be less profitable if sold for housing, usually located deep within the colony. Students attending the school would not necessarily be residents of the colony and would have to enter the gates to reach the school in the morning. While residents objected to the location of the school well inside the boundaries, a more ideal location near the arterial road was reserved for commercial purposes by the developer. "That was one of the reasons why we got a bit unpopular," said Sanjay of the RWA, "because they [residents] were saying that you stop their entries, and no we [the RWA] can't do that, [the students] have legal rights." This sparked a movement against the RWA that failed to gain traction. The issue of the school and non-residents entering the colony provoked outrage among some of the most progressive environmental activists. Re-reading the trash mound episode considering this information, perhaps the waste issue was never purely a material threat. Outsiders and garbage are both "matter out of place" in the gated community (Douglas, 2003). Fear of unknown people, a lack of control over one's home territory, on its visual and health effects are related threats to material and symbolic reproduction. They are threats to place, as it is individually or collectively conceived. An analysis that identifies these conflicts as based in class identity alone, without recognizing how identity and place shape one another, misses a key motivational element in the defense of middle-class sensibilities or RWA claims. 


\section{Part 2: DLF City's RWA}

"It will be alright in the end, and if it is not alright, then it is not yet the end" -quotation on the wall of the DLF City RWA Office

"Now there is a lot of resentment amongst the residents because they say why should I be paying two taxes? So, the problem arises when the municipal corporation, who recovers the property tax, they're supposed to render certain services...But those services are not forthcoming."

- Head of the DLF RWA, 2015

In 2015, a decision was taken in Chandigarh, the seat of Town and Country Planning, and Urban Local Bodies Department for Haryana. Developers of colonies, such as DLF Phases 1-4, were to hand over maintenance and non-mandatory service provision to the municipality. According to planning authorities, this decision was taken upon complaints from residents themselves, who were frustrated at paying a house tax to the MCG, while also paying maintenance fees to developers. Developers would be responsible for ensuring that adequate infrastructure was already provided i.e. power backup or sewerage treatment. These facilities would have to be upgraded before the MCG could take over.

According to the head of the DLF RWA, this complaint was a misunderstanding. In contrast to Nirvana Country, DLF's RWA had a more amicable and trusting relationship to their developer, and lower expectations of the MCG, who collected the house tax and shared its revenues with HUDA. While some colonies objected to the house tax, Nirvana's RWA had not. The Head of Nirvana's RWA stated that the house tax was not an exorbitant fee, but a gesture of civic loyalty to 
local government that had been particularly receptive to Nirvana's desire for autonomy.

DLF City's RWA, at the time of research, was the largest in India, with 8,000 members, representing a population of almost $125,000 .{ }^{132}$ Unlike Nirvana Country, their RWA was a separate entity, with full time staff and an office. While they had the same collegiate structure and held elections, their size precluded residents from having as direct a relationship to its Executive Committee (EC). The RWA had therefore decentralized its operations. Each phase had a federation that operated as an extension of the RWA, with a president, etc., to cater to on-the-ground services. Some areas had begun to form even larger sub bodies called confederations. ${ }^{133}$ The Head of the DLF City RWA characterized his and the organization's role as more of an "interface" between residents and DLF. There was no question of ending that relationship.

Mandatory services were provided to DLF housing by the government or the local city administration, including water, electricity, and sanitation facilities. For example, HUDA supplied water to DLF at a single point in the mornings and evenings for about 30-40 minutes. DLF then paid HUDA redistribution charges and piped the supply through water lines in each phase. The redistribution charges were then passed on to residents through maintenance fees. Individual houses and apartment complexes had water storage towers and tanks, which filled during supply hours, and enabled steady access to piped water at any hour. DLF also had its own sewerage facility, as

\footnotetext{
${ }^{132}$ Roughly 10,000 households lived in apartments, comprising a population of about 50,000, with roughly 400 apartments in each complex. About $50 \%$ were managed by DLF, and the others by the RWA of a given complex, usually at a slightly lower rate (1.75 to 2 Rs per sq. yard).

${ }^{133}$ In the state of Haryana, there is a joint action forum, JAFRA.
} 
well as fire department, unconnected to any state agency or authority. Electricity was provided through DHBVN. ${ }^{134}$ The agency supplied metered electricity individually to each household, and electricity bills were paid directly to the provider.

The RWA offered or facilitated everything else with DLF. Every resident, including those who were not members of the RWA, paid maintenance fees to the developer, in addition to municipal taxes, or property taxes (the house tax) to the MCG. ${ }^{135}$ To become an RWA member, there was a one-time 1000 Rs membership fee. In addition, residents (whether members of the RWA or not) paid DLF 2.50 Rs per sq. yd on a given plot for non-mandatory services in plotted areas (detached homes). Over time, the costs had gone up, straining the budget and threatening the overall quality of services. ${ }^{136}$

The head of the DLF RWA was concerned with the MCG's ability to deliver non-mandatory services when the developer left the picture, with only the house tax as a source of revenue. ${ }^{137}$ At the time of our interviews, the takeover had not happened,

${ }^{134}$ Dakshin Haryana Bijli Vitran Nigam (DHBVN) is a Haryana state owned utility company that distributes electricity to 10 districts, including Gurgaon.

135 This is different from federal income tax, which is dispersed.

136 DLF has two kinds of housing, plotted areas and apartment complexes, with an even split between the number of residents in each. DLF phases 1,2,3, and 4 are plotted, with about 10,000 households. Phase 5 is predominantly apartment complexes, with an additional 10,000 households in "new Gurgaon". DLF has no role in Old Gurgaon. Out of the total number of roughly 14,000 plots, there are 10,000 occupied, so about 4,000 vacant plots. These spaces become difficult to police or maintain. As discussed in the previous sections, vacant plots attract waste dumping. Managing these spaces is a challenge for developers and the RWA. 137 These services included: 1.) Conservancy and general upkeep, sweeping of roads, door to door garbage collection and its disposal, cleaning of unwanted growth of plants in vacant plots, repair/replacement/painting of signage, guide maps and gates. 2.) Cleaning of storm drain \& sewage lines. 3.) Road repair/patch work for roads. 4.) Repairing \& strengthening of boundary walls and fencing. 5.) Maintenance of electricity distribution network for smooth supply of electricity (supplied by DHBVN).

6.) Supply of drinking water. 7.) Maintenance of street-lights. 8.) Maintenance of Parks/green areas. 9.) Plantation of trees in parks, green belt $\&$ and left-over areas. 10.) Tree pruning as per 
but MCG's entire budget for the city was equivalent to the maintenance dues collected for only four phases of DLF. DLF's RWA was understandably concerned about how services would continue as usual without additional taxation on households. How many of the above services would MCG be able or willing to continue offering? Or would they eventually adopt the same system DLF had or allow DLF's RWA to do what Nirvana's had done and decide their own standards of service and contractors?

The greatest fear for the RWA, in letting the MCG take over from DLF, was not sanitation or waste management, however, but issues of security and policing. Fear of encroachment or infiltration continued to worry the RWA, as they invested in CCTV and better lighting for streets and parks at night and continued to monitor vacant plots. The fear of unknown persons described earlier in this section in the battle between Sushant Lok A block and The Ivy, as well as in Nirvana, share this territorial or self-preservationist logic. While many of the participants I interviewed were glad for the advocacy and work of their RWAs, their concerns often brought them into conflict with their RWA and city government.

Although the RWA story highlights the scaling up of placemaking from the individual to the collective, or interest-based formation of civil society, this is not the only scale and means through which residents have advocated for improvements in networked infrastructure, environmental governance, and planning accountability in Gurgaon. In looking at what might be at stake for individuals from different communities or gated colonies organizing over issues of place, its preservation,

requirement. 11.) Round the clock security including patrolling guards/QRTs and CCTV cameras. 
improvement or protection, it is important to recognize that place is socially constructed not just at the scale of the home, the private sphere or the gated colony and semi-private/public, but also at the city or national scale. This layer of personal identification through place may encompass a set of ideas about government, democracy and ideal sense of what constitutes civic life in those places. ${ }^{138}$ Loyalty or belief in the values of that government, an allegiance of sorts, is also a form of attachment (Hidalgo \& Hernandez, 2001). ${ }^{139}$

\section{Beyond the Gates: The Good Citizens}

"The only thing that can save Gurgaon is its citizens. I have no hope from government. It's strong to say no hope, I should say, I don't expect answers from government alone or from politicians... If the change is to come it's to come from the ground up."

- Romila, Interview, 2015

The manifestation of these attachments in Indian middle-class activism is nothing new. It was central to the nationalist movements of the pre-independence period, as well as the social reform movements by the educated or elite classes that followed (Srivastava, 2015; p. 88). In the post-independence period, however, considerations of the poor and how to address wealth disparities also led to the rise of civic organizations and NGOs (Kudva, 2005). There are neoliberal inflections in this trend, and the RWA activity highlights a new battle of protecting self-interests. As RWAs find themselves collaborating with or fighting with a freer market, in the post-

\footnotetext{
${ }^{138}$ Nationalism can be seen as a form of place attachment and identification, in which an "imagined place" is representative of both a group and an individual identity, the citizen (Bonaiuto, Breakwell, \& Cano, 1996).

139 Sometimes referred to as "civic place attachment" at the city or urban level (Hidalgo \& Hernandez, 2001).
} 
liberalization period, the boundaries between citizenship and ownership become blurred. Middle-class and elite users and consumers of the state (as infrastructure) are also materially vulnerable to its breakdowns. Activism around these interests can dovetail with the efforts of RWAs but represent interests "through a renegotiation of the relationship with the state which has historically represented itself as and has been popularly understood to be "pro-poor'" (Srivastava, 2015). I would argue further that the self-interested aspect of middle-class activism has also been internally renegotiated to function under the duties of urban citizenship. This comes with an acknowledgement that historically and recently, at least, the middle and upper middleclasses have had to draw on networks of privilege to access the state. The middle-class participants in the research were aware of and often mentioned their minority status as a vote bank. As one resident put it:

"[W]e are a very insignificant population in this country anyways, you know people who are thinking and challenging, and we don't matter to the vote banks...the politicians don't care about us because we're too small" (Interview, 2015).

The head of the DLF City RWA had also expressed disappointment in municipal ward counselors, many of whom were described as uneducated. "The vote bank is mainly in the villages...The system seems to have failed."

What I wish to emphasize in the concluding sections of this chapter, are the many ways in which NGOs, not concerned exclusively with the poor, have coalesced broadly around interests common to both the poor and the middle-classes, extending beyond the preservation of property into the broader public realm, or in search of one. Many of the participants in the research were affiliated with multiple NGOs. While this chapter's aim is not to provide an exhaustive list or argue that Gurgaon is an 
exemplary or unusual hotbed of this type of civic placemaking-related activism among the middle-class, it is worth mentioning a few of the more prominent cases. I Am Gurgaon, for example, has relied on funding through corporate social responsibility campaigns to restore Gurgaon's Aravalli Biodiversity Park. A group of transportation planners and activists put together a pedestrian and cycling day in Gurgaon called Raahagiri, which came out of concerns about road safety, and conversations with Gurgaon's traffic police (now a national movement observed in cities across India). Gurgaon First, runs workshops related to campaigns for promoting solar energy, worker safety, women's safety, taking on, to some extent the idea of community development and educating stakeholders. ${ }^{140}$

According to its organizer: "All of us are more informed, more knowledgeable, and it's not for the authorities. It's for the stakeholders, there are NGOs, there are citizens there are a lot of discussions happen a few things have emerged." An organization called "We the People" focuses on civic and constitution related awareness and education and connects with different organizations in the NCR and Maharashtra. The primary organizer, who seemed to have an implicit awareness of the ways in which attachment to place and civic engagement might coincide, was a Mumbaikar originally, whose husband was from Haryana. She contrasted her experiences at home with Gurgaon:

"Mumbai is a hotbed for civic involvement, but people don't have the time, and that's one of the very sad things about Mumbai, is that you have a lot of people

\footnotetext{
${ }^{140}$ In a later chapter, I discuss information related to traumatic crush injuries in second tier auto parts manufacturing workshops among migrant workers. That information was obtained by attending one of Gurgaon First's workshops, where auto manufacturing executives were brought onto a panel with migrants who had been injured.
} 
who really really feel it for Mumbai... Gurgaon people will not tell you Gurgaon has made me what I am."

Those who tended to have more time to manage, and a prior background in activism or social justice related causes, felt a pull to activity. "In Mumbai, because it's so big, and fragmented in some ways, you'll have small communities, you step just a little bit out into bachapur and you still see those communities, very traditional communities, but here, because it's smaller, a little more contained, but people are used to being in a city, they think of Gurgaon as a whole."

\section{The Good Citizens Part 2: Bourgeois Environmentalists vs Citizen Scientists}

"We are actually compelling them to think about planning... They make maps and they draw lines on them. Drawing lines on maps is not planning, by any stretch of the imagination. Social and environmental impact assessment reports make the basis for urban planning, if you don't make and generate those reports how do you plan?"

-Amina, Interview, 2016

Two houses down from Rita's house on A block extension in DLF Phase III, lived Amina and her husband, both artists. She was a sculptor. He was a filmmaker. The couple had spent the past several years collecting data on Gurgaon's water bodies and taking local government to task in the media and in closed-door meetings with their MP for mismanagement of a now defunct waste incineration plant at the top of an aquifer in a village on the boundary of Gurgaon district. They financed their own tests of the water after the government claimed it was potable. They brought the contaminated water to the Haryana Pollution Control Board, asking them to drink it.

"This is how we do advocacy, we use the reporters, print, video, we sign petitions, we try to sensitize people, make noise, but not just noise, also action, research, like we sent up our own money to get the water tested, we all pooled it in together." 
Concern over the environment was one of the most pervasive themes or complaints among the participants in this chapter. This was voiced initially as part of the story of moving to the city in the 1980s and 1990s when it was the hinterland of Delhi, and not yet urban. As explored earlier, many homeowners were in search of better air, green space, and safer streets, something closer to a version of nature most had experienced in childhood vacations and travels. ${ }^{141}$ But the role of landscape and nature in providing symbolic meaning for residents quickly became imbricated with material well-being. This pull to nature had personal connections to property, to family, and health. Many, if not most, of the participants in the research had medical concerns, or a parent or child who they moved for; someone affected by pollution, the burning of rubbish, or sickness from drinking untreated water. Pollution was tangible, one could feel it quite intimately in the body. Amina recounted:

"I moved here because my daughter had asthma. I moved here to keep her safe. And now the pollution has just chased through, within 20 years...My parents had to move out of here because they can't breathe here anymore. It was supposed to be a quiet city hamlet, but the exact opposite has happened."

These fears were not exaggerated. On a good day, the air quality in Delhi, NCR and Gurgaon is 99 on a scale of PM 2.5 pollutants. These toxins, when inhaled, can penetrate the blood brain barrier. At its worst, Delhi's air has a 999 PM, or 16 times the safe limit, equivalent to smoking 50 cigarettes a day. ${ }^{142}$ This pollution also

${ }^{141}$ Consistent with the idea of "environmental identity," or the inclusion of nature into one's self-concept. Such attachments are directed toward a natural environment (Clayton, 2003).

${ }^{142}$ PM stands for "particulate matter", both solids and liquids suspended in the atmosphere. PM 2.5 refers to inhalable particles in the air of 2.5 micrometers or smaller. PM 10 are considered less hazardous because particles over 10 micrometers are less easily absorbed by the lungs or taken into the bloodstream. There is no single source of PM. Various toxic chemicals, pollutants, dust, and organic matter can contribute to index levels. Some of these particles are emitted directly from sources such as trash burning or construction, while others 
contributes to the greenhouse effect over the city, whose South Asian summer temperatures already hold steady over 100 degrees Fahrenheit until the monsoon comes. Gurgaon is close enough to Rajasthan's desert, and to regions of Haryana and Punjab where slash and burn agricultural practices still take place and send particulates north and southeast. Despite this arid climate, there is a wilderness, the Aravalli hills, which straddles the boundary between Delhi and Haryana, cutting through Gurgaon, if briefly. I am Gurgaon, only five minutes from Sikanderpur village, was working to replant the arid landscape with carefully selected indigenous plants. Further afield, the Aravalli's sacred groves were under attack. The Haryana government was pushing the NCR to apply the loosest interpretation of "urbanizable" land to its master plan, which would enable Haryana government to acquire and develop on forest previously protected by environmental laws. In short, it was difficult for career environmental researchers and activists to focus on a single issue, such as water, or air pollution or deforestation. Each issue required grappling with not only weak institutions and enforcement, but the reversing of well-intentioned interventions.

Case in point, the aquifer polluting waste incinerator Amina and her husband were focusing on. The plant had shut down due to a fire some years back. The technology was a mismatch for the region. The waste wasn't calorific enough to burn. Why, the couple wondered, had the government decided to build it in the first place, and why had they chosen this fragile location at the top of the aquifer? Ironically, the

form in the atmosphere from chemical reactions i.e. sulfur dioxide and nitrogen oxide from car exhaust, or industrial production processes. 
misplaced incineration plant was the result of an even more vocal resident prompting action from above. The man who compelled local government to act:

"He's just a citizen who wrote to the municipal commissioner "kuchera is falling off and we need to take some acres in the Aravalli and put it there. I said no, Indian waste does not have the calories to make electricity, please if we can just segregate it, more than enough that we can do with it, they bring foreign engineers into India, 300, 400 crores of public money was spent on it."

There was a certain unease in this. While the activist couple had worked hard

to build their case and find solutions to some of the flooding and contamination issues

in Gurgaon, they were simultaneously dismayed by the pace at which different

administrations and agencies rushed to solve these problems with untested solutions.

To fix flooding issues, they concretized the existing natural water catchment areas,

which only exacerbated the problem. They relied on developers to build water

treatment plants one colony at a time. They listened to the advice of one concerned

citizen and invested money into a project that proved unfeasible and caused more

harm than good. While the couple were glad to have their research and concerns as

citizen scientists taken seriously, the fact that such a void in expertise existed, in

which the knowledge and self-funded studies of ordinary citizens could gain so much

traction, also frightened them.

"They called us environmental experts...It's me telling a government official, giving a government official the maps and telling them where to look. I'm sending government of India surveyor maps. They call us for the meeting, I keep wondering "what the hell?" So they now want us to do a solid waste management, they said would you please do it, and I wonder what all these agencies and all that tax money going and going where? To whom?"

As discussed earlier in this chapter, discourse on middle-class environmental activism in and around Delhi characterizes these anxieties as class-based, as part of a larger tension over public space: a "middle-class pursuit of order, hygiene and safety 
and ecological conservation, through the public sphere” (Baviskar, 2011, p. 392), which echo Chakrabarty's (1992) discussion of public health discourse, first introduced under colonialism, but also reiterated and reflected in the post-colonial state. With these long-standing relationships between cleanliness and class in India, and its reinforcement by colonial practices, and the rationality of planning, it becomes difficult to carve out an untroubled, authentic or healthy relationship between communities of affluence and "environment" in the middle-class Indian city. Whereas the colonial authorities who focused on health and hygiene in sanitation reform understood little about the actual vectors that spread disease, and proposed solutions based on many of those, typically racialized, assumptions, a great deal of these questions have been settled by empirical and scientific research. It is no longer a matter of conjecture whether inhaling pollutants decreases lung capacity or contributes to respiratory illness. Activists do not always rely on the visceral response to something unpleasant in the public sphere when making a complaint. They can test water, provide documentation, and evidence to demonstrate, as citizen scientists and popular epidemiologists, that "eyesores" are often more worryingly linked to systemic problems and failures of infrastructure or basic governance and oversight (vigilance). I do not wish to heroize or romanticize the middle-class fight for place, but to consider it in a broader context and conflict over the "right to the city". All the participants in the research have common desires, needs and aspirations. The appearance of conflict, or of a zero-sum game, in which middle-class residents fighting for the provision of services or the right to obtain them on their own or attempting to address the broader environmental (and aesthetic) issues beyond the gates, is not an imperative based on 
necessarily preserving the social pecking order or securing scarce resources. Planning failure in this context makes the tragedy of the commons a visceral, totalizing experience shared across socioeconomic lines, albeit to different degrees of severity. Some of the horror is self-directed. The pile of waste beyond Romila's walls, the kuchera being dumped or burned in water catchment areas and at the top of aquifers, the depletion of water tables and so on, is more often the result of construction and affluent consumption practices. The depletion of ground-water tables for the mixing of concrete and the deforestation of sacred groves are the results of real estate speculation and marketization of land. Residents and the environments and places they wished to preserve, recreate or build from the ground up are villains and victims of their own activities. Planning, in this context, is citizen-centered, corrective, and retroactive. It becomes a form of coping in the face of disrupted attachments to past and future places. The assumption of a cultural hegemony of middle-class or bourgeois environmentalism and placemaking must recognize the heterogeneity of middle-class identities and ways of living, the differentiated values, attachments, and experiences that lead to action but also intergroup conflict, even within a single common interest development. It is important to recognize that while these efforts may not always "get it right," they often strive for a more just or socially inclusive platform. This is not to defend all middle-class activism either, but to suggest some room for variation, and to find ways to allow for the possibility of social innovation. What constitutes the “common sense" of India's moral middle-class, to continue in this Gramscian line of thought, hasn't been decided in a definitive sense. 
To hold the efforts of high profile or powerful organizations accountable to self-stated missions of social inclusion, for example, is an important and helpful critique that can lead to a reflection on a more inclusive notion of placemaking. How NGOs and activists might expand on or adopt a wider vision of place that incorporates or recognizes the presence of lower-class others, of other temporalities within the same space, without relying on assumptions baked into hierarchical distinctions of human worth, requires more than a recognition of privilege and deference to others. It requires new conceptualizations of shared space and place that take time and often arise from conflict in the public sphere, as well as renegotiation in its aftermath. Given the urgency of everyday ecological hazard and planning failure, the efforts of various citizen scientists and ordinary people to question the leadership within their communities, local and state governments, to challenge the norms and behaviors of their neighbors and friends, to be practitioners in the formulation of place and themselves with respect to it, makes categorical assumptions seem of the moment. What is common to "these groups," and for all participants in the research, is a desire to belong, and a relationship to place that undergirds and motivates secondary emotions, action and for many, reinforces a higher aspiration to "good planning" that transcends what they may witness in the present tense. This iterative, rather than static, way of conceptualizing place is challenging for those who came to Gurgaon under certain assumptions, as well as for those who have always called the district home. 


\section{CHAPTER 5: THE URBAN VILLAGERS}

\section{Introduction}

"In 1980, this was a jungle. There was no DLF. The land was not suited for irrigation, and drought could have devastating effects...We had a particularly bad time then in the village, if there wasn't a good harvest. Wheat was to be harvested, but it wouldn't last the entire year...we had some land and I planted vegetables in it. I took the vegetables to sell them in the mandi. During that time, people didn't have a lot of money. There was no development."

-Jasveer Yadav, Sikanderpur Ghosi Village ${ }^{143}$

We sat in the offices of a local NGO in Sikanderpur Ghosi, only a few kilometers from DLF phases III-IV. The village and the DLF colonies shared a municipal ward and an elected Counselor to the municipal government. ${ }^{144}$ Phase IV and Sikanderpur were the same stop, Guru Dronacharya, but different exits on the elevated metro line from Delhi, opened in 2010. The village housed laborers and domestic workers employed in DLF housing colonies who crossed the road in the mornings to garden, cook, and drive for the residents of DLF Phase III. The village occupied, however, a radically different category of land use as an abadi surrounded by its lal dora ${ }^{145}$, or red line, in master plans. While Haryana became a state in the

${ }^{143}$ All interviews with the Yadav elders in this chapter were conducted in Hindi and Haryanvi. Oral histories were later translated to English. Interviews with the adult children of the Yadav household were conducted in English.

144 There are 35 wards in Gurgaon with one elected Councilor per ward. Disparate housing colonies and urban villages are often thrown together within overlapping ward boundaries. Sikanderpur Ghosi's counselor at the time of research was a Villager by ancestry, whose address was listed within a DLF colony. She was (as of 2016) answerable to the village that voted her into office, though it was suggested that she had ties and allegiances to DLF through her spouse.

${ }^{145}$ Lal dora, or red line, refers to a demarcation of an urban village boundary. In this case, it separates that space from the municipal authority of a city. Such villages are often exempt from some of the same land use and building standards as the surrounding urban fabric. 
1960s, its land was still subject to the Punjab Scheduled Roads and Controlled Areas

Restriction of Unregulated Development Act, which essentially created these pockets, abadis, or the lal dora of village land. The law has been amended many times.

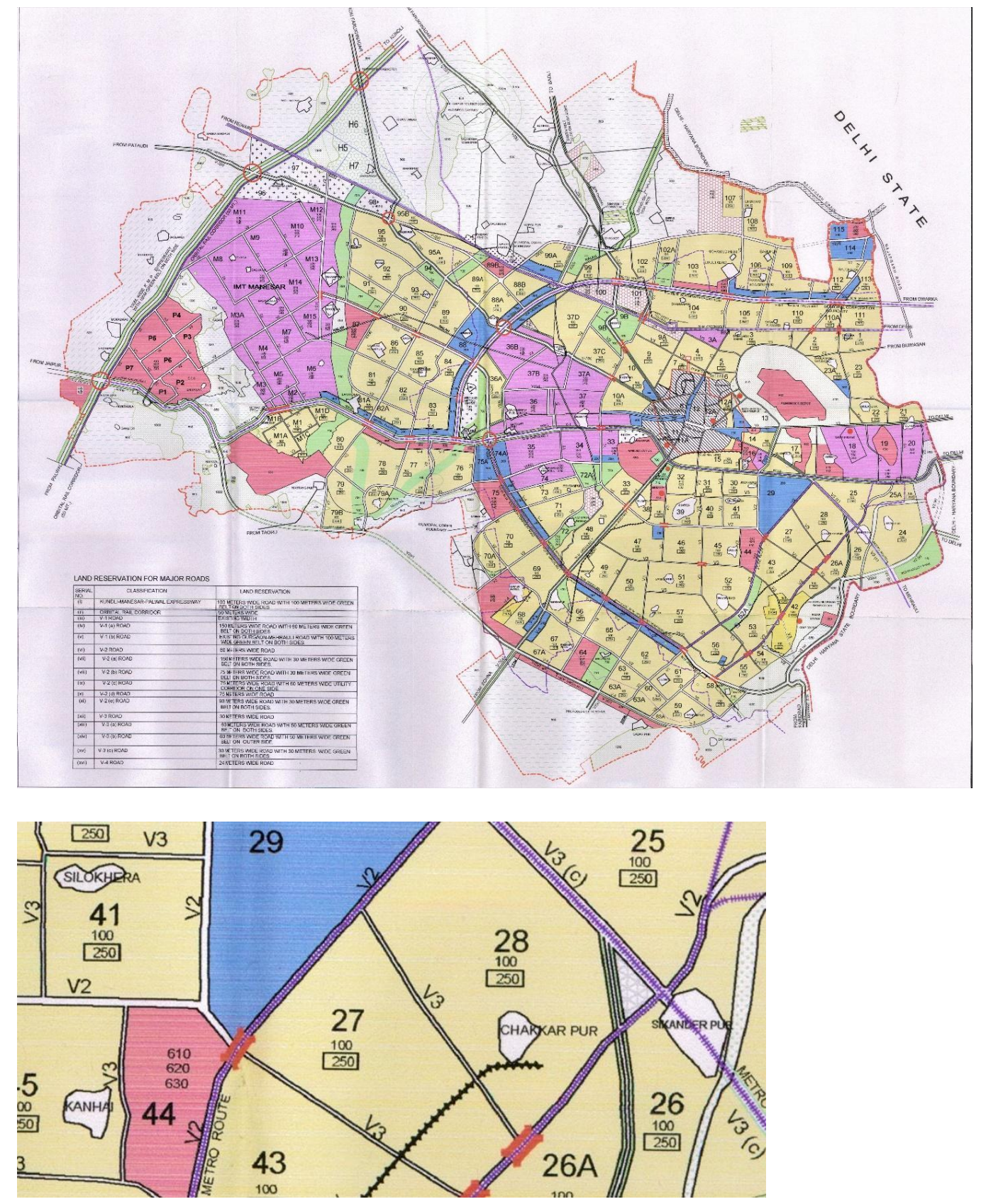

Figure 10: Gurgaon masterplan, with closeup on village abadis (white) 
I was introduced to Yadav, who identified himself as a social worker for the village first, a landlord second. His ancestors had been in Sikanderpur Ghosi for generations. His grandfather was the village Sarpanch for 25 years. ${ }^{146}$ In the 1980 s, the primary source of income was farming (vegetables, wheat and millet). Yadav's ancestral home was not in the village proper, but in a hillier area where it was often difficult to subsist on agricultural yields or wheat production alone. Though the family owned cattle, much of the land was barren, and they could not afford to employ outside laborers.

Despite the precariousness of agricultural yields, the family had been relatively well off in the years leading up to Gurgaon's urbanization. Several members had moved into government service by the late 1960s in the Department of Food and Agriculture. Yadav's father and brothers were educated, and he was the only son (of three) who did not matriculate in school. "I didn't have my mind in studies, so I used to plough the land with the bullock."

DLF was one of the first developers to approach Sikanderpur in the 1980s. When villagers sold their farmland, roughly $90 \%$ bought land $30-40 \mathrm{kms}$ away, and continued to collect rents in the village in addition to farming on the periphery. But eventually the city's boundaries would catch up to those peripheral purchases on Sohna road or along NH8, or in Rajasthan, Alwar, and Rewari. The less-landed villagers were not able to make the shift, gave up on farming and lived solely on rents. Yadav observed that those who initially invested in more land further afield were

${ }^{146}$ Sarpanch - literal translation is "head of five", referring to the elected leader of a panchayat or village council composed of five representatives. 
better off in the long run. Others went into business, acquiring a truck or a bus, but eventually found themselves back on the land they had left, attempting to farm it and collecting rents, or selling to developers.

As the farmland and common land ${ }^{147}$ was sold or developed, villagers began building upwards within the lal dora (red thread or village boundary), replacing existing structures with modern concrete, brick, and rebar reinforced multi-story apartment buildings. Joint homes and large families became cramped in the village, even with the vertical extension of buildings. These spaces were at a premium and earned enough in rent to justify putting the family elsewhere. "If a family had 5 children, they weren't able to live here, they sold their lands here and got more land for cheap outside this area." Lucrative as rents were, Yadav's generation was entirely dependent on them. He stressed the importance of education for the younger generation, the ambition to find a profession through a formal education, preferably in IT or corporate sectors, outside the village.

This chapter follows accounts of village life in Gurgaon from the 1960s onward and the ways in which changing socio-economic conditions and demographics

${ }^{147}$ By some estimates, there are currently 246 villages in Gurgaon District (2011 Census). Villages were originally composed of three approximate geographic areas. The first and largest was farmland, privately owned in small holdings of 3-4 acres per household, followed by common lands, used for communal grazing. Housing and water storage and markets clustered within the village center. In the urbanization of Gurgaon, agricultural lands were the first to be acquired because they were the most expansive and their ownership was less ambiguous. The commons, which did not have distinct ownership, became sites for informal housing settlements, as well as ongoing contestation between state and private actors (Narain, 2009). The central built environments of villages have become the primary hubs for lowincome housing in Gurgaon. Villagers have built rental housing in the form of small, densely clustered huts (jhuggies), or within multi-story flats. Some villagers have continued to live adjacent to these rentals, while others have moved beyond the village. These spaces are rented almost exclusively through informal housing arrangements and oral agreements (Naik, 2015). 
have reconstituted these places over time. Far from wiping out the influence of urban villagers, these transformations, along with the dissolution of the panchayat system, have led to the transmigration of village politics into the municipal ward and city-level governments. At various moments, political parties and state level politicians have attempted to appease or shape the demands and political persuasion of Gurgaon's Urban Villagers. At the time of research, the city's mayor was a local Yadav representative who defeated both BJP and Congress candidates for his seat in 2011. In June 2016, Haryana issued a mandate to reserve 18 of Gurgaon's municipal ward seats for SCs (Scheduled Castes) or OBCs (Other Backward Classes), the exact figure the BJP would have needed to win a majority in Gurgaon. In the election, BJP affiliates won only 13 seats compared to 21 Independents (primarily members of local dominant OBCs in urban villages). While there is considerable diversity among the ancestral communities of Gurgaon, there is a broader reputation for backwardness and defiance (particularly resistance to outsiders) among Haryanvi communities native to the District. Although the focus here is on the oral histories of a Yadav family, the communities referred to in this chapter are differentiated in terms of income, class and caste status, but share a sense of historical marginalization, despite recent political and economic ascendancy. Urban villagers (who may themselves be middle-class according to economic indicators) have often been pitted against the middle-class milieu of gated colonies described in the previous chapter.

The villager story sits awkwardly in scholarship on Indian urbanism. In recent years, a scholarly conversation has emerged from the peculiarities of Gurgaon's urban villages. For example, Cowen (2018) observes the unusual characteristics of the 
villager story, and how the voluntary sale of land, and the enrichment of local farmers may unsettle the accumulation by dispossession narrative and offer new insights into the so-called agrarian question. This angle may be helpful in considering the ways in which landed agricultural communities hold different stakes or form resistance to the loss of land and the benefits of capitalist expansion, industrialization, or urbanization. ${ }^{148}$ For scholars of agrarian studies, the story of subsumed village lands in expanding Indian cities may disrupt categories of urban or rural land use and life in particular ways (Gururani, 2013). Far from rebelling against a capitalist mode of production, former agriculturalists embraced rentier capitalism, but faced criticism from middle-class elites for ostentatious or conspicuous consumption and reckless spending of new wealth. Cowen (2018) discusses the concerns of villagers on the periphery of Gurgaon, who sold lands but later stated they felt they had been "looted" in the process. This chapter, to a certain extent, unpacks the "sense of being looted" for the urban villager as it relates to the construction or loss of place, and how this narrative affects the politics of placemaking in the city more broadly. In the immediate sense, there is the direct financial wrongdoing of robbery, theft, or of having been poorly compensated for one's assets in a land deal. To demonstrate, unequivocally, that this occurred, given the speculative nature of urban land market formation on the fringe of Delhi, is beyond the scope of this research. The courts continue to hear

\footnotetext{
${ }^{148}$ Agrarian studies address these questions, though the field is internally divided over the existence of the peasant in the modern world. Peasant attachment to land and position as both proletariat and proprietor, posed a challenge for the full realization of socialism in Marxist thinking. By resisting dispossession, landed farmers might halt the process of overthrowing the capitalist mode of production driven by urban industrial labor. Chandra, N.K. (2002). The Peasant Question from Marx to Lenin: The Russian Experience. Economic and Political Weekly, 37(20),1927-1938.
} 
petitions and cases against developers, and the recent charges against former Chief Minister Hooda and Robert Vadra of DLF confirm the level at which fraudulent practices threaten Villager lands. When DLF began acquiring land in Sikanderpur, an acre cost Rs 50,000 to Rs. 1 lakh. ${ }^{149}$ Present-day values are Rs. 4.85 crore per acre, a $4,850 \%$ increase. This staggering appreciation over several decades, combined with the visibility of government backed fraud in the present day, are real concerns. Looking at the urban village through the lens of place and the social construction of or attachment to it, however, we begin to understand why the stories developers used to secure sales were so effective. Many of those interviewed in this research expressed a sense a regret in their dealings with real estate developers, such as DLF, in the 1970s and 1980s. This "seller's remorse" often included, but also extended beyond concerns over the fairness and exact sum of a cash payment. As described in Chapter 2, familial tokenism, embeddedness, and appeals to kinship, made actors like K.P. Singh particularly successful as salesmen. Singh also knew how to sell housing to a globalized middle-class. His personal and place-based connections to Jat communities in Haryana also allowed him to pitch a narrative of economic progress to local farmers. The revelation that perhaps those pitches were based on the co-option of local knowledge and connections, that such relationships and insider practices could be used to grease the wheels of a sale, may contribute to this sense of being robbed. The sense of being robbed persists in the ongoing relationship between village landlords and DLF, as the former face continued limits to how they may reinvest or leverage wealth

${ }^{149}$ Lakh - one hundred thousand. 
that was generated in the sale of land, beyond education and conspicuous consumption. The condition of post facto marginalization (as economic actors) can also shed light on the ways in which caste groups, with historically agrarian occupations, may struggle to renegotiate the ladder of possible urban imaginaries and income generation (beyond rentier capitalism). Transitioning from agricultural labor to rent collection requires a change in one's relationship to land and labor itself. As in the previous chapter, class status figures into the discussion of village identity and place attachment for important reasons. Villagers defend their rights to the abadi itself, the spatial locus of "rural identities" to which they are still associated by a more globalized milieu. To add to the previous chapter's discussion of class identity, for the urban villager story of place and its construction, it is important to differentiate how class status intersects with caste and land around issues of income and livelihood generation. Lockwood (1989), drawing from Weber, made a set of three distinctions important to identifying class status: between one's "market situation," which relates to income itself, i.e. levels, source, stability and opportunities for upward mobility. This is followed by "work situation" or the relationships of subordination/superordination within employment. Finally, "status situation" relates specifically to lifestyles. One's status situation involves those more complex associations and elements of taste that refer to class status, one's self-perceptions about where they belong on some social hierarchy (sometimes, but not always, related to caste in the case of India). Awareness of one's status situation sheds light on those visible attempts to emulate those we perceive above us in status or distance ourselves from association with others (Jeffery et al, 2011; p. 114). One's solvency, or wealth, 
the type of employment and social status as visible through conspicuous consumption patterns combine to form a multi-layered packet of features that must be achieved to truly merge with the globalized middle-class in gated Gurgaon. From listening to accounts of the Yadav family's income, it was understandable that even market situation (income) could come second to things like professional and social status in the designation of middle-class. Various trajectories for professional development, making place, and participating in civic life have emerged from the increased leisure time available with the landlord occupation, but it is also a position of precarious power and status that must be actively maintained, often through intimidation or protest. A place-centered analysis provides a lens through which to make sense of these complex class, labor, caste and land relationships, particularly when village histories consider stark differences in the attitudes of a younger generation aspiring towards and even welcoming Gurgaon's urbanization, changing values, gender roles, desires and ways of living, that highlight an internal division in the strength of the village attachment and its primacy as a place of both material and symbolic reproduction in the coming years.

\section{Sikanderpur Village}

According to census reports from the early 2000s, Sikanderpur Ghosi had 5,000-6,000 residents. Estimates by a local NGO, however, put the population closer to 70,000 residents during the same period. ${ }^{150}$ This under-calculation is true across

\footnotetext{
${ }^{150}$ Interview with Head of Aravalli Scholars, educated-based NGO operating in Sikanderpur Ghosi.
} 
most villages in Gurgaon District. In the present day, villages like Sikanderpur have become sites for rentier capitalism and informal housing (slums). The majority of the urban villages' voters are local, while most of their tenants are migrant workers. On the one hand, the abadi's legal exemption has enabled Villagers to collect rents invisibly from tenants who do not exist on paper. On the other, the scale of this invisible humanity has strained the resources and quality of life in the village to a breaking point, forcing villagers to ask for assistance from local government and planning institutions.

The urbanization of the village didn't begin with Gurgaon's incorporation as a city, but decades earlier with the land use conversions and real estate investments of the 1960s and 70s. In his autobiography, K.P. Singh recounts his strategy, as Head of DLF, to convince rural farmers to sell their farmland and invest in the company's projects. When he first approached villagers in Chakkarpur and adjacent Sikanderpur, most families held no more than 3-4 acres. His plan to assemble 3,500 acres, without access to capital, required convincing villagers to loan him back the money he paid out for their land at roughly $12 \%$ interest (Singh, 2011). Thus, hundreds of village households, approximately 700 according to Singh, not only sold their ancestral lands and gave up farming in situ, they also became entrepreneurs and angel investors in DLF's projects. This collaborative relationship, and its eventual souring, is important to understanding the nature of the ongoing animosity between Villagers and not only DLF, as a corporate monolith, but the urban public DLF represents. When participants spoke of these deals, the grievance is more complex than the issue of compensation or the loss of a rural landscape. There's a recognition that by selling land specifically, 
and on DLF's terms, Villagers enabled private developers to dictate the path along which the village's spatial relationship to the city could evolve. Within the lal dora, it is administratively difficult to establish clear ownership rights. ${ }^{151}$ While villagers can supply certificates of possession for their buildings, and continue to collect rents on them, land ownership has never been as clearly established within village boundaries as it was with revenue-based small farm holdings. This has forced villagers to choose between possibly losing any claims to the village by leaving it or to stay on as landlords. The DLF sales, combined with restrictions in Haryana's land use laws, would ultimately limit villagers' ability to enhance, improve, protect or advocate for the land they retained inside the village abadi, or to urbanize in a way that met their reimagined sense of place in the millennium city.

By his own accounts, Singh canvassed in villages using his family name, his status as a Jat, and performances of social recognition. "I used to dress in a kurtapyjama, wrap a shawl around my shoulders, and wear a beret on my head. I would squat on the floor of their huts and drink the refreshment they offered. I even shared a few puffs of smoke from their hookahs as it would have been impolite to refuse" (Singh 2011, p 102).

Regardless of the tactics, participants speculated that Singh or his associates may not have been entirely honest about their connections and approval from state actors. In some accounts, papers and licenses were forged to convince Villagers of the legitimacy of the project.

${ }^{151}$ Interview with representative from the Deputy Commissioner's office, 2016. 
Singh's initial pitch, that the farmland was not productive, and that farmers would benefit from buying land elsewhere was consistent with participant histories. ${ }^{152}$

Nonetheless, Singh noted that it was difficult the persuade families to part with their lands. "The emotional connection was extremely strong" (Singh, 2011; p. 104). Almost an afterthought in Singh's accounts, the remainder of this chapter takes up the nature of this emotional connection and the ways in which it has survived and changed over time.

\section{A Village History Retold}

Sikanderpur's history, as told by a Yadav landlord, inverts the wasteland narrative Singh used to convince farmers to sell (depicted in Chapter 2). While Yadav's retelling confirmed many of the statements about the land's limited productivity for farming, he framed the village as a place of resilience and societal stability before the entrance of DLF. "Earlier people lived in harmony," he said.

"In the beginning, our village has 20 Yadav homes. If a cow died in any of these homes, we would get a to transport and sell the cow. Hence a Chamar family was called into the village and given land, to perform these functions. We need kumhars to make pots, light lamps - so we helped a kumhar family make this village their home. ${ }^{153}$ We needed pandits to do havan and puja - so we got them in the village and gave them land. From their personal lands, since there was so much love (brotherhood) then, people gave portions to help create a society. Now, it is more about if you have more. I will take from you. I got this inspiration from Lord Krishna.

152 As discussed in Chapter 2, in the 1960s, newly created Haryana was one of five states to participate in Green Revolution programs. However, Gurgaon District was unsuitable for these investments due to its distance from the Yamuna and the soil's poor drainage (Gururani, 2013).

${ }^{153}$ Kumhars are classified as OBC. They are traditionally known as potters and manufacturers of earthenware, members of an artisan caste. Regionally, they are further subdivided into touchable and untouchable communities within the group. Chamars are considered an untouchable or Dalit group, associated with tanning and leatherwork (Rawat, 2011). 
He came to Mathura ${ }^{154}$ and created a sort of society, brought people together. This was done to save people from Kan's ${ }^{155}$ violence, so he got everyone together - saying I will give you prestige and responsibility."

Yadav's reference to Hindu cosmology and the story of Krishna speaks to the founding mythology of Yadav identity and the group's continued self-identification as favored non-elites (Lord Krishna was said to be a champion of the oppressed in society) (Goopti, 1997). ${ }^{156}$ It is unclear how long Yadav's family had lived in the region, or whether they had been part of migrations in the past century. Brayne's (1929) accounts of his work on village uplift in Gurgaon has little mention of Yadav communities. In accounts of Yadavs from the early 20th century, an "agrarian depression", combined with a massive population boom, triggered a wave of migration among agriculturalists from Uttar Pradesh within the shudra ${ }^{157}$ communities, not limited to Ahirs, Kumis, Gujars, Pasis, Khatiks, and Yadavs. ${ }^{158}$ In urban areas, these communities found employment as laborers, carters or porters for urban trade businesses or in construction or masonry and as kahars or water carriers. Towards the

${ }^{154}$ Mathura is considered one of the seven holy cities of India, located in Uttar Pradesh, about 150 miles South-east of Delhi and known as the birthplace of the Hindu God Krishna.

${ }^{155}$ Ambiguous pronunciation, but could be a reference to Kansa or Kamsa, the uncle of Krishna and former tyrannical King of Mathura. Though Krishna was said to be born in Mathura, he had been secretly raised elsewhere due to a prophecy that, as the 8th child of his parents, he would eventually kill his uncle, which he does.

${ }^{156}$ Yadavs are considered Other Backward Class (OBC) in India, traditionally associated with agricultural work and cattle raising. Their origin story ties their ancestry to King Yadu and Lord Krishna. They were the dominant sub-caste group in Sikanderpur and across many villages in Gurgaon.

${ }^{157}$ Fourth and lowest rung in the varna class system, associated with service-oriented professions and laborers.

${ }^{158}$ In Goopti's account of Shudra migration in the early 20th century in UP, there is speculation that groups might have left the state and gone West due to overzealous British urban planning. Specifically, in the 1920s and 30s planning authorities pushed the eviction of poor groups from cities, who were blamed for overcrowding and the spread of disease. 
latter portion of the 20th century, landless migrants took up work as masons and bricklayers in exchange for food. Yadav echoed the reports of colonial authorities, of roving caste groups (migrants), who joined "societies which had abundant resources." Time seemed irrelevant to Yadav's cosmological order and harmonious society from an indeterminate past. ${ }^{159}$ The events that took place in his own lifetime, in the $1960 \mathrm{~s}$ and 1970s, however, marked a shift from this collective memory of a harmonious society in the village to a contemporary market economy: "Now it is more about if you have more".

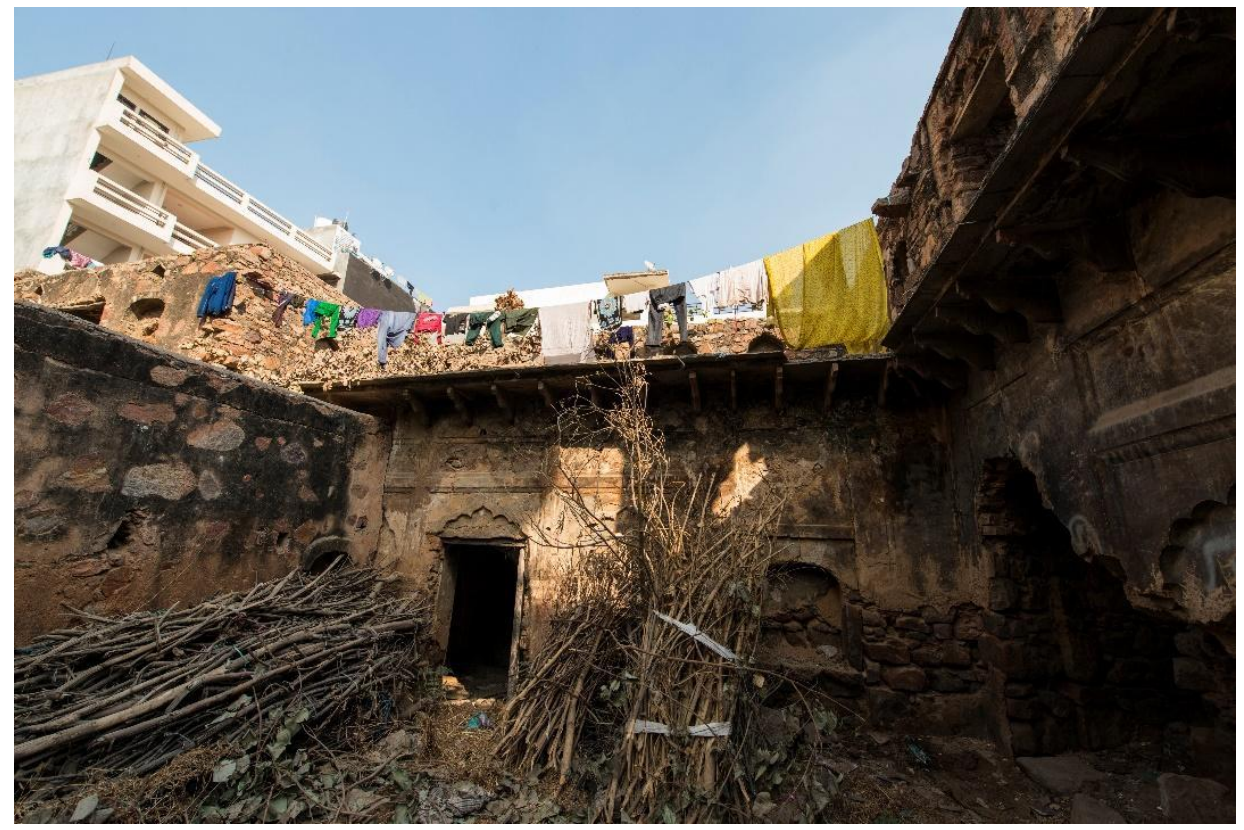

Figure 12: Haveli in Sikanderpur Village, now used to store firewood and fodder. Pukka apartments in the background.

${ }^{159}$ Colonialism was missing from this narrative. 


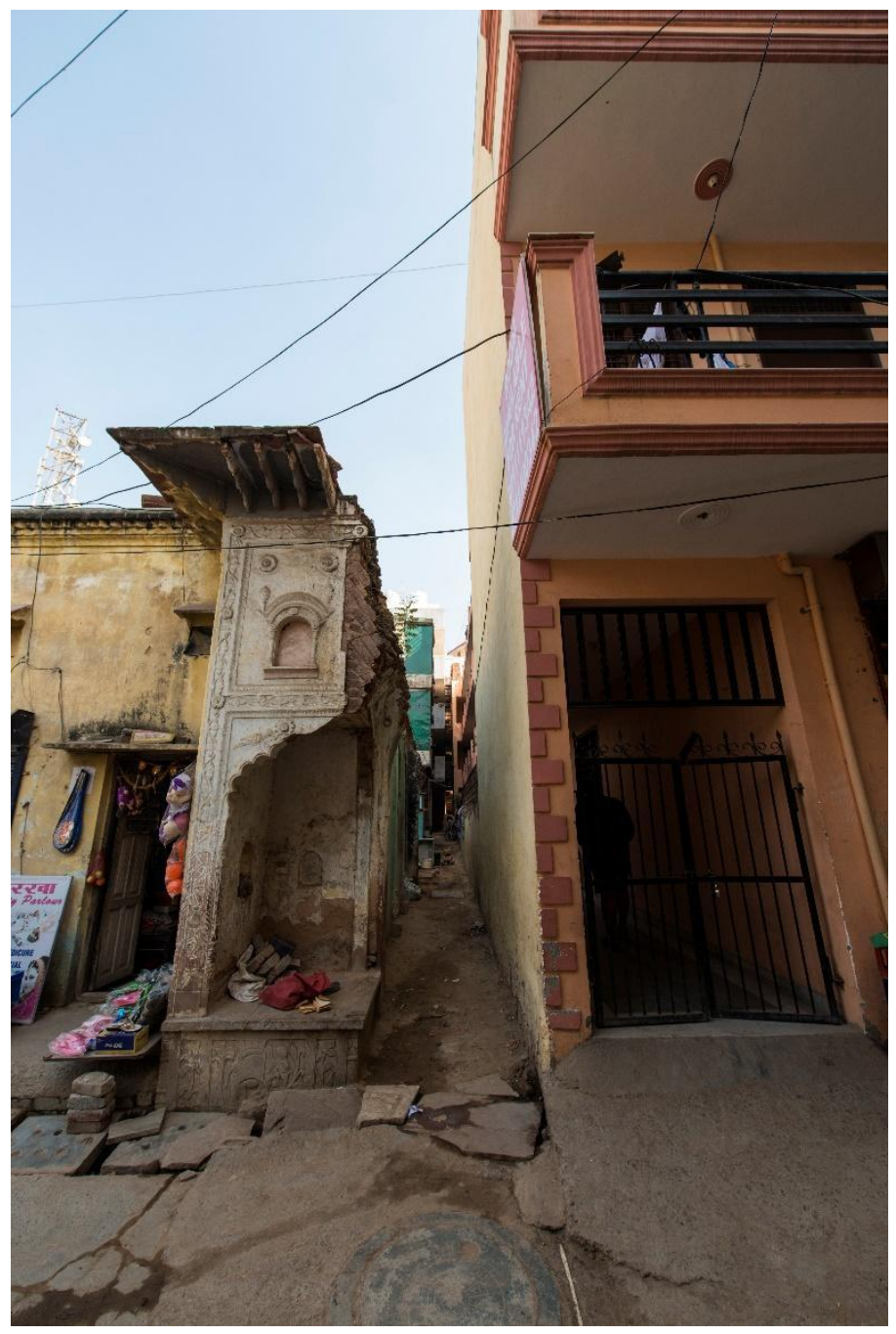

Figure 13: Old and new construction in Sikanderpur Village.

The process of becoming urban began slowly and then accelerated. As DLF began to solicit and purchase land in the 1980s, space in the village became scarce, building methods and materials changed, but living conditions initially improved. When DLF first came to the village, most of the surrounding land was riverine or hilly plateau, kept out of agricultural production, and roughly 500 acres of that hilly land was not owned by the Villagers individually, but by the village Panchayat. Once relatively flat arable farmland was sold, Villagers had the option to acquire land outside the district with the profits and continue farming, or stay, verticalize and 
collect rents in the abadi. Many did both.

"Earlier we had jhopdis in a line. ${ }^{160}$ If someone set fire to one, it would have burned down the entire village. Slowly the houses became concretized. As buildings came up, people would look at each other's constructions and start improving their own. Space had reduced, but the population has increased. Now, look at the portion I own, my second brother lives upstairs, and above him is my third brother. All this vertical rise was not happening in the village earlier. People used to construct chaubaras ${ }^{161}$ above their homes, but never such stories one on top of each other. Now, the land we own is $100 \mathrm{gaj}^{162}$, because of the land crunch all three brothers have to live together in such a way. I have land $10 \mathrm{kms}$ outside the village. It's more open out there, there is no space here. Existing space has been put on rent."

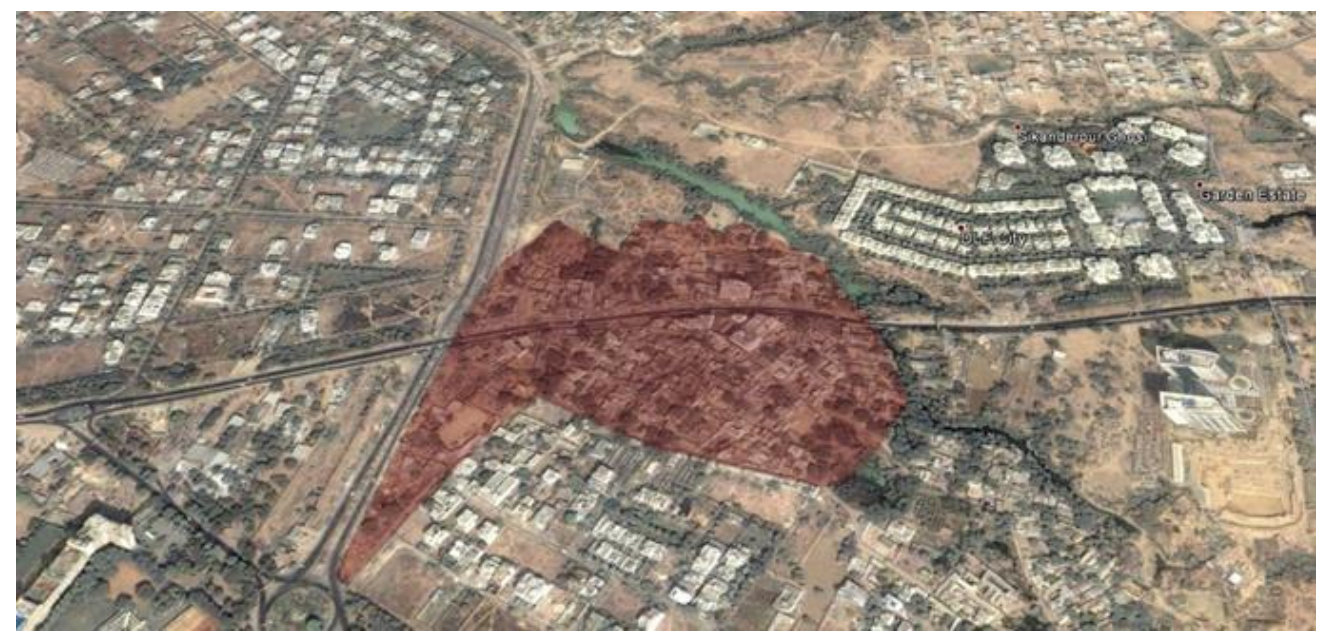

Figure 14: Sikanderpur 2001

${ }^{160}$ Jhopdi - one-story cottage or hut, in this case made of mud or brick walls with thatched roof.

${ }^{161}$ A type of shed.

${ }^{162}$ Unit of measurement. 1 gaj is equivalent to roughly 9 sq. feet. 


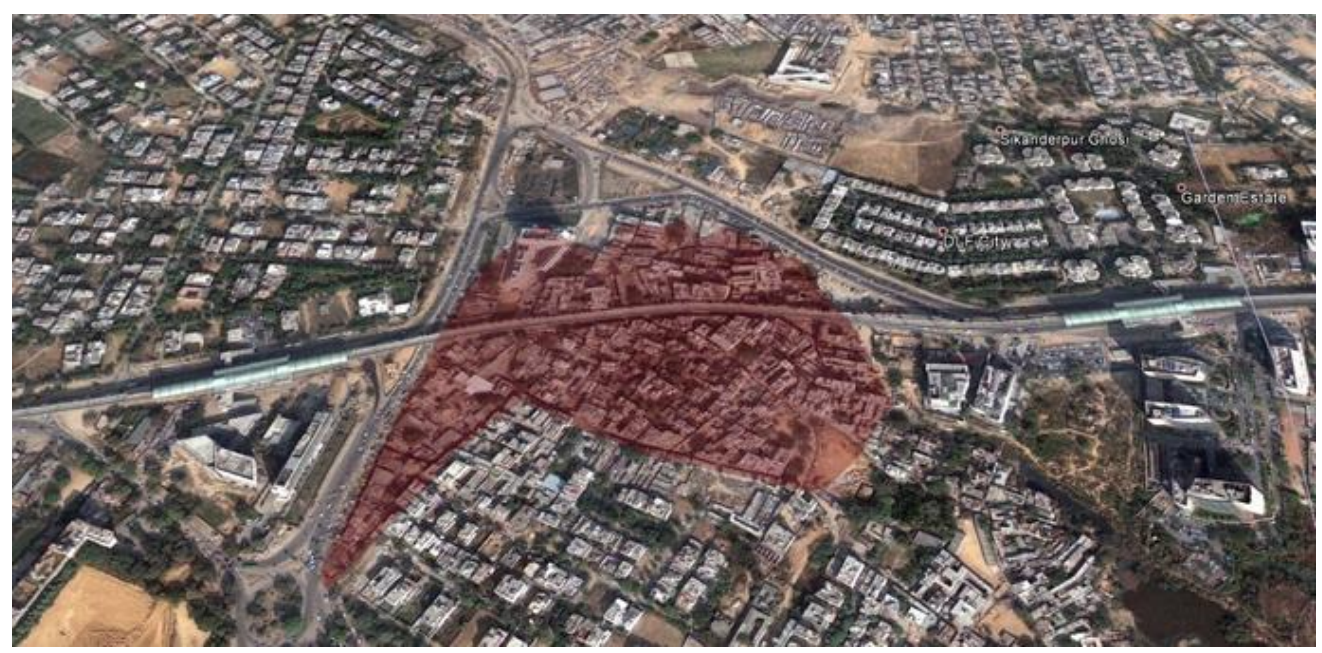

Figure 15: Sikanderpur 2015

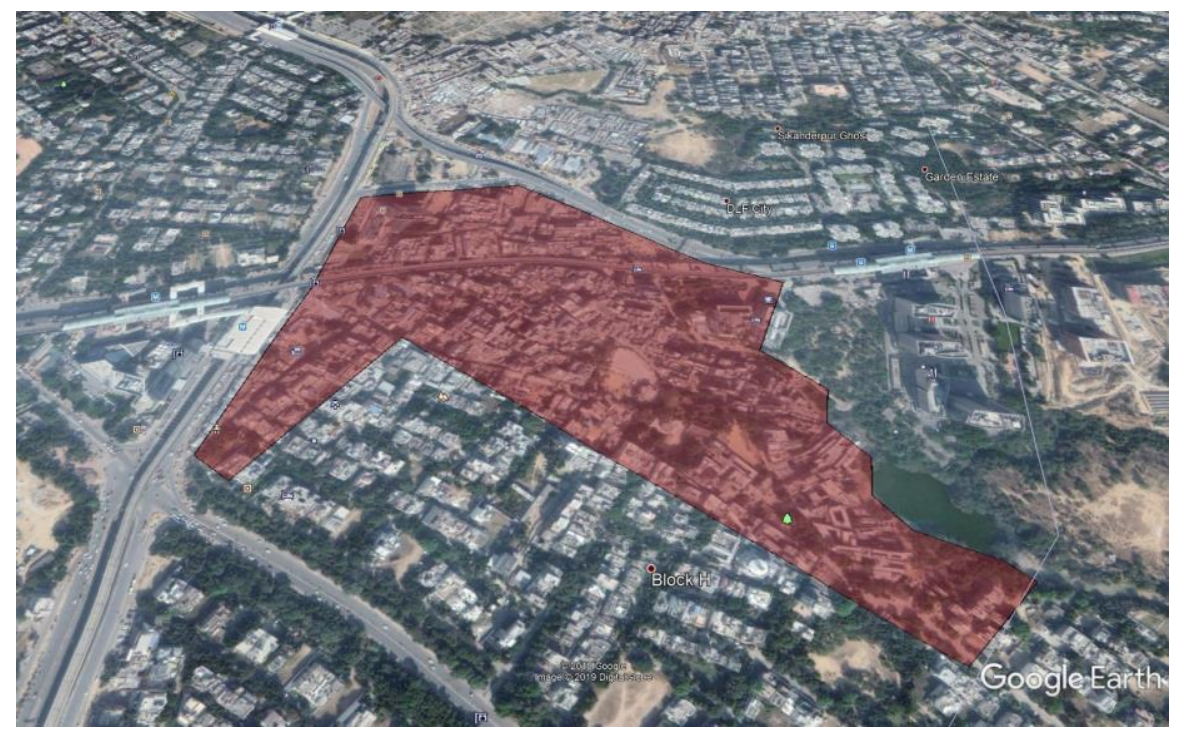

Figure 16: Sikanderpur 2019

The flat land was most profitable, and the family leased out a plot on the outskirts of the village to a mall developer, who rented the property as office space ("moffice space"). The earnings from the mall were divided among the family's three brothers. According to Yadav, rent supported households across the social hierarchy of the village, with a monthly minimum income amounting to Rs 50,000. Yadav's 
monthly income was Rs 2.5 lakh, though he collected rents from the same buildings as his brothers, who took home similar incomes.

"This includes everyone from a harijan ${ }^{163}$, a balmiki ${ }^{164}$ or the top most caste in the village...Even a very poor person, who sweeps the floor, and is a native of this village will earn Rs 50,000 a month. Historically every person was allotted a plot from the Gram Panchayat to construct a home."

At this point in Yadav's narrative the careful ordering of society in the village began to fall apart. The initial sale of land was a boon, and incomes were up. Even those at the lowest rungs of the village social hierarchy had bread. As the story unfolded, it seemed there was a partial presumption, based on the partnership model Singh proposed, and the language of the deals, that DLF had entered an ongoing relationship of vertical patronage with the village. When that failed to materialize, the village took a hit.

"DLF made a lot of money from us. Builders made a lot of money from us, they sucked our blood. DLF created a boundary and segregated the village and villagers - they won't allow us now. There were no livelihoods generation, the village was completely cut off."

DLF construction projects blocked access roads into the village, reinforcing the spatial isolation of the enclave. There may also have been a presumption that DLF would directly employ Villagers in professional roles and that did not come to pass.

"There are no entry points to the village from any side. As a result, we got totally cut off. People of the village are facing severe scarcity of water while DLF is easily getting water for construction. Water is going from our lands, but we aren't getting any."

${ }^{163}$ Harijan, a term used to describe a member of the lowest caste group, untouchables. The term was popularized by Mahatma Gandhi, intended to mean "children of god," it retains a negative connotation "rejected by Dalit activists and intelligentsia from the very moment of its coinage in 1932" (Rawat, 2011).

${ }^{164}$ Balmiki, a term also used to describe persons belonging to a low caste, formerly untouchable. They are associated with work related to cleaning or removing waste, unblocking sewers, etc. 
DLF was able to use mechanized pumps to extract groundwater for construction projects, siphoning off village supplies. ${ }^{165}$ The johad that once supplied some of the village's water was filled in some years ago, and a community center was built on it. ${ }^{166}$ Eventually the village needed supplies to be pumped in through government pipelines, but the abadi's informal status and the challenges of fragmented governance for the city as a whole made it impossible to determine who was responsible for the village's water connection.

"The problem is that HUDA said no, and MCG says what can we do? We laid the pipelines. Now they say that they don't have enough water to supply the village of Sikanderpur. Officially, there is no society amongst the villagers. There is a constant clash with MCG people...HUDA is responsible for providing water to all Gurgaon, but they are not providing any water to Sikanderpur. There is no water connection."

Yadav believed that the remaining villagers did not stay in the village by choice, but out of economic necessity. As we continued to discuss the infrastructure and amenities within the village, DLF became more than fly-by-night thieves, but played an ongoing offensive or vampiric role in the narrative; taking over resources, preventing modernization and infrastructural development in the village, as well as obfuscating the village's political presence. DLF was a powerful actor, but also representational. It included the RWA, corporate interests, residents, and anyone associated with the housing colonies, or the forces that kept the village in a state of infrastructural invisibility and underdevelopment. DLF represented bourgeois attempts to un-see or ignore the Urban Villager's presence and right to a place in the city.

165 Villagers relied on tube wells, with water table estimates at $300 \mathrm{ft}$., but worsening (as of 2016).

${ }^{166}$ A johad is a water harvesting pool for village needs. 
"If you observe, as soon as you step out someone will spray mud on your clothes - there is no cleanliness, no sewage lines for us. HUDA and DLF sewer lines are inaccessible to us. We have been deeply inconvenienced by DLF's presence. We had to take a roundabout way covering $2 \mathrm{kms}$ extra because DLF had blocked all the entry roads. There was a fire breakout some years back and the situation got worse since fire brigade could not find sufficient space to come down to the village."

Under the Indira Vikas Yojana ${ }^{167}$ villagers could retain their common lands, Sikanderpur's claims were denied when a private builder gained permission to build a 5-star hotel on former panchayat land. DLF had already begun building flats there, and Villagers were unable to make the legal case. Yadav said that the MC was informed of DLF's encroachment, but that the original land lease documents had been taken over by DLF.

"They refuse to share. I have requested so many politicians, press reporters to show the dire situation. I will file RTI ${ }^{168}$...I am ready to fight for this cause, but I have issues in reading and writing. I need help there as well... I am not afraid...I do not want to enter politics...But I want the village to prosper.... I tried to establish unity and brotherhood."

Until Gurgaon achieved municipal corporation status in 2008, Sikanderpur, like other villages in the District, relied on the panchayat system. ${ }^{169}$ With incorporation, the village council system was dismantled. The displacement of a local autonomous government had an economic cost to households who collected farming subsidies under rural status. Yadavs were already running for political office in the NCR, ${ }^{170}$ and eventually, began running for office within the MCG's ward system. At

\footnotetext{
${ }^{167}$ Reference to a social welfare program launched under Rajiv Gandhi in the mid-1980s with the Ministry of Rural Development. It offered subsidies to the rural poor to construct their own housing.

${ }^{168}$ RTI refers to the 2005 Parliament act, procedure to request information from government.

${ }^{169}$ Village council system.

170 For example, Rao Birender Singh Yadav was the second Chief Minister of Haryana and Chaudhary Brahm Prakash Yadav was the first Chief Minister of Delhi.
} 
first, locals listened to the overtures of career politicians, but eventually decided to take matters into their own hands.

"We elected the MLA ${ }^{171}$ here. He later became a minister. After getting to office he does not care. This is the job of the Haryana government. They don't do anything."

From the 2016 records, eight Municipal Ward Councilors had listed mailing addresses as a VPO (village post office), and an additional six listed addresses within village abadis, accounting for $40 \%$ of the city's seats. In the 2017 election, more than $60 \%$ of the seats were won by Villagers. Anxieties over the loss of rural subsidies, livelihoods and governance or political representation, as well as provisions for government jobs were not unique to Gurgaon's villages, but spoke to a larger foment among historically marginalized groups during the time of research, that eventually coalesced into visible protests. ${ }^{172}$

Yadav mentioned that if the MCG did not listen, villagers were planning to block the roads. ${ }^{173}$ Sikanderpur/s Municipal Ward Counselor at the time of the research was herself a villager. Yadav was skeptical, pointing out that she lived in DLF Phase III housing. Her husband had ties to DLF. Who knew if she had turned?

"She keeps on saying "I am trying". She is clearly lying because she has no other work, no other areas of focus. She does not want to solve any issues for us. Other parts of this area are super developed...DLF guys are not going to give votes,

${ }^{171}$ MLA, or member of a legislative assembly for an Administrative District.

172 During fieldwork in 2016, Jat agitations gripped Haryana's government, and spread to other states in Northern India. Rioting incurred several billion dollars in damage to public infrastructure. In March 2016, the Haryana Backward Classes Bill was passed, reserving new job and educational quotas for OBCs to include Jats. Yadavs already held this classification. 173 As Srivastava (2014) points out, Gurgaon's village politics intersect with tensions over caste designations in India: "Gujar agitations, demanding downward mobility in order to launch upon and upward one, sit alongside the wider context of desire and understanding of change. The difference between the Gujars and the occupants of the gated enclaves lies in the perceptions of such change." 
but DLF knows where all the people get elected from. It supports those who support DLF. I thought about going folded hands to DLF to ask for development here.”

Yadav's take was that the village was disempowered, politically and socially, and the MCG did not see their needs as legitimate. "Villagers don't have power. But we stand together to fight for our rights. We want things to go through proper channels." At the beginning of our conversation, Yadav had asserted that he was a social worker first, a landlord second. He was adamant that his position was not a political role or equivalent to that of the sarpanch legacy of his grandfather. He referred to his profession multiple times, his daily occupation, as social work:

"I am not a politician. I stand up for the village, for the country. I am a person who wants to give voice to people who need me. I do not identify as a political leader...I try to help people out, even if it's some injustice happening to a laborer, I will speak up for them."

\section{The Rent Crop}

The Yadav family owned flats within walking distance of their home.

Estimates from the family put the average number of tenants per building between 200-250, and no more than 3 persons to a one-room flat, although cursory observations showed this figure was likely higher. In total, this would account for 10,000 tenants across not more than 2,000 units. ${ }^{174}$

Naik (2015) observes that landlords in Gurgaon are peculiar within the literature on South Asian informal housing. They present a hybrid of "petty bourgeois"

174 Some buildings might have 10-100 rooms. Rent was collected by visiting flats in person on the 10th of the month. In order to obtain a rental, a potential tenant would need to offer one month's rent and security in advance, plus proof of identity. Electricity was paid at the end of a monthly period based on meters for each room. Piped water was free. 
and "subsistence" landlordism, relying almost entirely on those rents for income, substantial as they may be. This wealth has generated the new "crorepatis", ${ }^{175}$ solidly middle-class or wealthy, if judged on income alone, but still socially stigmatized and excluded from a cultural understanding of what it means to be middle-class in Gurgaon.

Yadav did not consider the landlord role to be a genuine profession. Cultivating the land was the job of a zamindar, not simply owning it. There was an idea of labor that didn't seem to apply to making the rent collection rounds, although maintaining housing for tenants was part of the job. Given the ambiguity of land ownership (in contrast to building ownership) within the lal dora, avoiding close government scrutiny of village tenure arrangements, and maintaining the rent crop, was the priority. "If this stops half of the village will go hungry. Before... I used to farm, now this (rented land) is my farm and rent is my produce." Yadav and his brothers reflected on the distinction:

"Being a zamindar, I was very clear on working with my bullocks...and I couldn't do business. Those who have been doing business for a long time can do that. A farmer can't do anything other than farming. If his children are educated well - they can go out to the city and do business. But here in the village, you go to your farm and plant and safeguard your produce. This is our job, what I told you - going to the fields and coming back."

The analogy of rent collection as a new form of cultivation is problematic when extended to the relationship between cultivator and the source of rent, the human tenants who comprise the majority of Sikanderpur's population. The dearth of formal

${ }^{175}$ Crorepatis, word for millionaires. A crore is equivalent to 10 million. The term has a similar connotation as "the nouveau riche". 
housing for the working poor in Gurgaon has guaranteed the income of families like the Yadavs, but also put migrant households, predominantly from Bihar and West Bengal, in a precarious situation. The issue of abuse, intimidation and voter suppression was raised by NGOs who assisted migrants with the administrative hurdles of achieving local residency. Cowen (2015) cites instances of abuse and bullying among landlords, and other forms of villager pressure and social control. "The locals see migrants as their hunt and [they] are forced to purchase rations from the landlord's shop lest they be evicted" (p. 70). In interviews with migrant tenants, who incidentally did not rent from Yadav's family, there were reports of abuse, even physical violence from guards or intoxicated members of the landlord family. ${ }^{176}$ During the same period, and in some of the same research locations, however, Naik (2015) found migrant tenants were also seeking and receiving assistance from their landlords, who were often flexible on rent payments and other matters. Respondents in Naik's study did not view their relationships as entirely negative, and the universality of oral contracts between landlords and tenants (as opposed to written leases) did not necessarily imply exploitation, Naik points out. Such agreements could often signify a certain level of trust between landlord and tenant.

Furthermore, accounts of hostile treatment, vs. vertical patronage varied by family, village, and dominant caste group. For example, Sikanderpur was majority Yadav households, while Nathupur village, also in Ward 25, just adjacent to DLF

\footnotetext{
${ }^{176}$ On several occasions, while conducting interviews in slum settlements, I was interrupted or questioned by guards who wanted to know why I was there, and in some cases asked me and my assistant to leave. There were some localities my Assistant did not feel comfortable visiting or were told not to visit by migrants because the risk of altercations with Villagers was too high. This did not occur in Sikanderpur.
} 
Phase III, was predominantly Gujjar. ${ }^{177}$ The Urban Villager was not a monolithic

figure. There were many families and related communities, who held different

attitudes and approaches towards their businesses and tenants, as well as varying

concerns. In some cases, the antagonist was the migrant, in others, it was the private

builder, DLF (even K.P. Singh himself), or the resident of a gated colony, the turncoat

Villager who left the village and joined the upscale RWA, or the government itself.

What was common to these cases was a sense of threat, or injustice in the face of loss

and perceived (and literal) displacement and social isolation.

\section{The Landlord's Daughter}

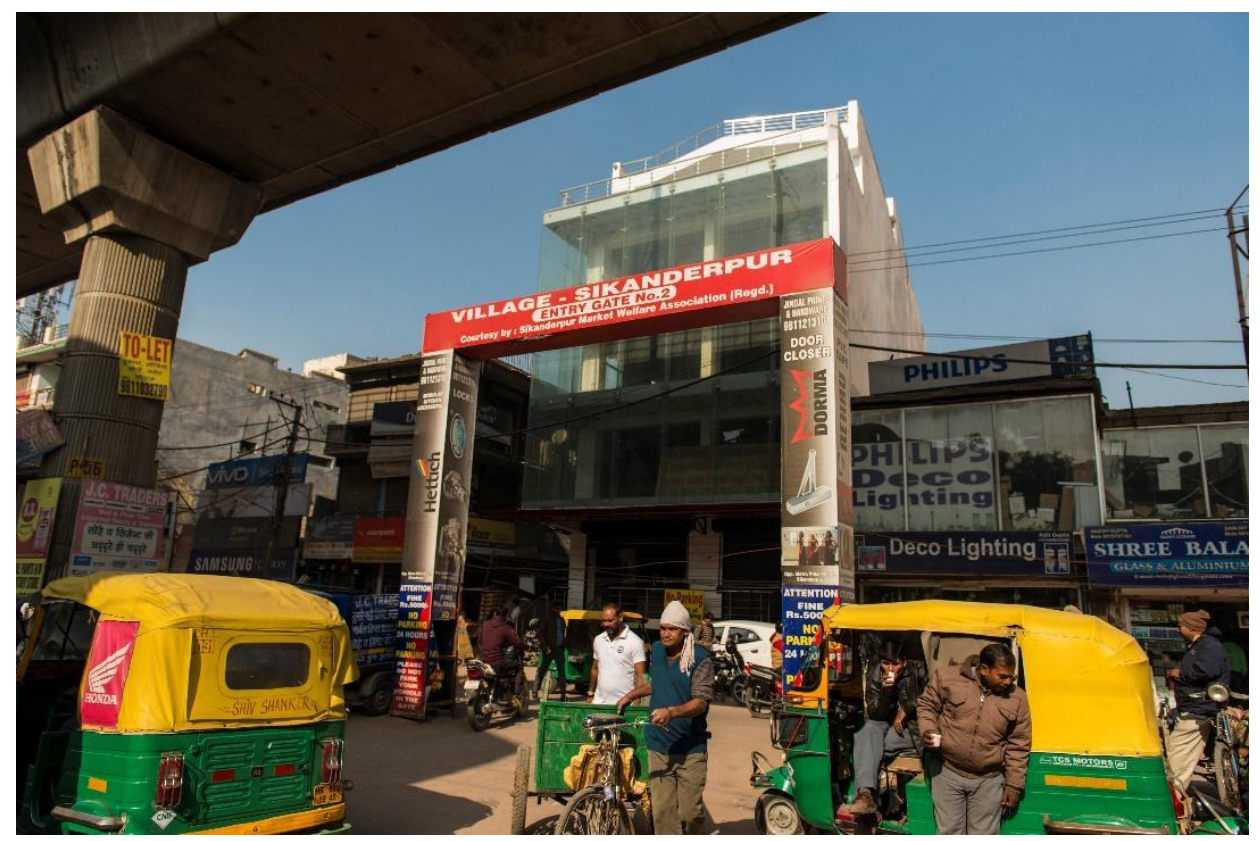

Figure 17: Entrance to Sikanderpur Village below the Delhi metro line.

177 Oldenburg (2018) conducted interviews in Nathupur over many years and was welcomed within that village by the Gujar community. She also reports having difficulty approaching Yadav households in Sikanderpur. I did not have difficulty approaching Yadav households in Sikanderpur; however, I was warned not to approach Nathupur by migrants living in Sikanderpur. These intergroup politics, reputations and fear highlighted that one could not think of urban villagers as one community. Caste boundaries were crucial and different communities were not necessarily on friendly terms with one another. 
After many weeks of texting and phone calls, Priyanka Yadav confirmed that she had finished her exams and returned from Noida for the weekend with her family in Sikanderpur Village. Her uncle came to fetch me outside Guru Dronacharya metro station, a man in his 60s, he greeted me, and initiated our highway crossing, walking into the four-lane, two-directional traffic, without hesitation. Five minutes later, after we'd pantomimed a conversation across the road, his hands telling me to "just make a run for it", I joined him on the other side, and entered the back entrance to the village. The path to the Yadav home took us through a dense interior of winding lanes. Once filled with single and two-story homes, many of the buildings in the village's core had been razed or rebuilt as four to five story apartment complexes. The one-lane roads were still used by livestock, pedestrians, cyclists and small vehicles. This explained why, when I had taken cabs to the village, they usually refused to enter for fear of getting stuck and would leave me at an entrance along the arterial road.

The Yadav family home was a five-story concrete apartment building. Each floor had a flat belonging to one unit in the extended family, brothers and their wives, adult children of the brothers. Priyanka and her brother were Yadav's children. While not all the extended family lived in this building, there were at least 90 adult (18+) members of the Yadav family in Sikanderpur alone.

Priyanka greeted me in the downstairs entrance hall, where her uncle took a seat on a jute chair, and an elderly relative offered us chai. Priyanka asked if I wanted a coke instead, and we were joined by her brother, a few years younger. In her mid20s, Priyanka was a software developer by training. Dressed in a t-shirt and cotton 
sweats and chappals on a day home from school, she seemed relaxed, but eager to get away from her older relatives. Although she spoke to me in English, a language her relatives did not understand, she took me up to her parent's bedroom to separate our interactions. The conversation shifted to how few women there were in her classes. We talked about the challenges of being women in male dominated professions. We talked about shopping, which malls we preferred. Though Priyanka was a full-time student, and did not have her own bank account, she seemed to have no concerns for money. Her parents did not police her purchases, though they would snoop and ask questions when she appeared with a shopping bag from Ambience Mall. "Did you get a good deal?" Though she had a car, she found driving unnerving and would often ask her brother for a ride. While the family was close and would visit with each other, she stressed "everybody has their own stuff, they watch TV. We have 2 or 3 TVs; at any time, somebody is watching one of them."

The two siblings had an older sister who was studying near Jaipur, and the three of them had spent part of their childhoods in Rajasthan, returning to the village as teenagers to attend private schools in Gurgaon. Priyanka made a point of reminding me that they never experienced the village in the way their parents and grandparents had, only as an island within a city. There was a sense of being required, by their immediate families, to engage with the village, when their lives expanded increasingly beyond it. Priyanka used the word "independence" at various points in discussing her imagined future outside Sikanderpur, where neighbors and relatives would not be able to observe her comings and goings, or where her voice could not be heard through the walls at night. Unlike her father and grandfather, Priyanka had multiple degrees, 
including a bachelor's in technology and was in the process of earning an MBA. As a software developer, she was not only a female in a male dominated profession, but also engaged in something radically different and that carried a higher prestige in her parent's eyes than the agricultural work and rent collecting of her nearest relatives or even government service.

When I interviewed Priyanka and members of her family, I had already conducted similar interviews with residents of nearby DLF colonies and was aware of the kinds of lifestyle markers and preferences she referred to, as well as the twodirectional tension between these enclaved spaces. The siblings emphasized the desirability of becoming a certain type of middle-class. Money and education alone would not be enough to make a transition, but becoming independent, leaving a joint family and living on one's own, in a gated colony, were necessary. Priyanka hoped she could eventually have a "clean home" and establish a "personal life" separate from her interactions with her relatives. "Mindsets are changing," she said at several points in our conversations. She hoped to eventually move to a housing colony called Sushant Lok when she finished her degree, the locality where I happened to be living during fieldwork. Her face brightened when I mentioned I was staying there. "They are sophisticated, decent people." Her brother, meanwhile, was set on moving to DLF Phase I or II. "Have you been there?" he asked. "Have you seen it?"

Priyanka felt secure in her surroundings, but socially under the microscope. I was reminded of a newspaper story in Srivastava's (2015) account of village life. A girl had been raped in Noida, the city where Priyanka was studying for her degree. When interviewed for a formal report, village women had said "In our villages the 
women cover themselves up. Our girls do not make boyfriends. City girls come to lonely stretches around the villages and industry in obscene acts. Late night culture of the city has spoiled the girls." Priyanka did not relate her experiences in such terms, though it was clear she was sensitive to a certain kind of social pressure and ability to stake out privacy. She saw herself as both a city girl and a villager at the same time, occasionally reflecting the villager perception of the immoral city-dweller.

The tenor of the conversations changed when the great aunts and uncles were present. During an interview with Priyanka's uncle, she seemed embarrassed by his speaking Haryanvi rather than "proper" Hindi. ${ }^{178}$ When I asked her why, she explained:

"It's a kind of...perception in the mind of people...Haryanvi- they are very dominant, they don't know anything. Your people who speak Haryanvi they...I don't want to use that word...This is the perception of the people of Delhi, of people who can speak English. "Haryanvi, oh, the people are gavar."179

Priyanka and her brother described the language as brusque and "dominating," recapitulating a perception of villagers and native Haryanvi speakers as backward or uneducated. Discussion of class in India is never isolated from the caste-community question, and social imaginaries that vary by state/region/language. While older participants spoke of time, in terms of the before, during and after the development of the city, of bygone days in which social hierarchies preserved the peace of communities along occupations, a younger generation sat in silence. It was striking to

\footnotetext{
${ }^{178}$ Haryanvi, the local language in Haryana. It is not recognized by the state or national government as an official language of India. Haryanvi also refers to people from Haryana, or Haryanvi speakers.

${ }^{179}$ Gavar or Gawar are derogatory terms used to describe persons of low class, who may be uneducated, or from rural areas or villages.
} 
observe the degree to which Priyanka's father and uncle focused on work and market situations in their narratives, while Priyanka herself was most concerned with status, referencing specific locations she wished to move to, describing the residents of those locations, as well as expressing embarrassment and wanting to distance herself from their reveries, particularly in front of a foreign guest.

In their study of rural, wealthy Jats in UP, Jeffery et. al. (2011), observed the trend of investing in education and positioning family members to leave agricultural production. "In common discourse, the urban is a touchstone for what it means to be modern, and both also connote middle-class in contemporary India--for all that is urban." They further observe "attempts to cultivate an urban or modern style within rural homes and villages" (ibid). ${ }^{180}$

The importance of placing children in "good" jobs, as opposed to agricultural work was an almost universal concern for both landlords and their tenants. The latter had come to Gurgaon, in part, to educate their children. Over the past forty years, the Yadavs have lost a productive landscape. It is not simply the income or subsidies of that land that have meaning, but the historical ties to the land as well as caste identity. To be a member of a sub-caste group entails an occupational history that was specifically agricultural in the case of Priyanka's family. Agricultural land in the district has gone from $63.35 \%$ in 1971 to $5.84 \%$ in 2003, while built up land has gone from $11.36 \%$ to $47.82 \%$ (Srivastava, 2015, p. 147). Yet, even in describing his new livelihood, Yadav used the terms of a cultivator, that his rental incomes were his

\footnotetext{
${ }^{180}$ While the family discussed in this chapter were members of the village's dominant Yadav sub-group, Jats are also highly visible in district politics, and share in the social stigmas associated with villager/Haryanvi culture.
} 
crops, and land itself continued to provide a direct source of income. But he ultimately found meaning beyond being a good cultivator, as someone who could sustain the village through apolitical social activism and intervention.

The loss of agrarian landscape, or replacement, has also been accompanied by various forms of waste: an increase in pollution, blight, construction waste, rubbish, but also increased the idle or leisure time for persons who used to be engaged, albeit in hard labor, for most of the day. The loss of that form of work is a gain for their children and grandchildren, but new worries emerge in the management of wealth. Stories of ostentatious new homes, cars and other luxuries bought with land sales were part of a package of negative stereotypes about the ancestral Villager of Gurgaon. There was an overtone of disgust in descriptions of Villagers who were seemingly unable to plan their finances. Priyanka's comments echoed common refrains about the village as "unclean". Srivastava (2015) describes the "aura" the malls, gated communities and affluent spaces the Yadav children discuss as the seemingly "palpable stuff of personality development," while their parents and grandparents must deal with a "barter of dispositions." (p. 246). The desire to participate in or join the spatial practices beyond the village resonates more strongly with a younger generation that holds fewer ties to the land and its history. While their parents engage in embittered court proceedings over DLF's encroachment, a younger generation quietly plans its future life in DLF housing.

\section{Conclusion}

"The new city enlarged the scope for a radical and legitimate rejection of the village as that part of one's self which had out-lived its utility. The journey to the city now 
meant an acceptance of the new city of the mind, which was to be founded on the ruins of an earlier self."

-Ashis Nandy, 2001

During an interview in the early stages of fieldwork, as mentioned in the Preface to the dissertation, a resident of Gurgaon commented that the city lacked a “cultural umbilical cord." The conversation occurred in the resident's home in a gated community of cul-de-sacs and townhouses on the edge of Sohna Road. When I first visited Gurgaon, this part of the city had a frontier-like quality. A sense of cultural dislocation made a certain amount of sense. The resident of that gated community was not originally from Haryana. He was a member of a middle-class migrant group, who came to Gurgaon within the previous decade. The image of Gurgaon emerging from a kind of terra nullius or lacking a connection to a former place or culture, was a common thread in interviews with that cohort.

While the gated colonies discussed in the previous chapter can serve as an entry point into Gurgaon's urban form and identity struggles, they are not the only middle-class enclaves in the city. The territory on which Gurgaon urbanized has been a place of deep significance, not just by reference to epics or a more distant past, but within the living memories of its ancestral inhabitants and their descendants. By portraying stories of Gurgaon's original zamindars and Urban Villagers, this chapter offered a reflection on how urbanization has threatened and reshaped a cord that still exists for locals. The incoherence and fractured nature of urban governance in the city of Gurgaon has supported and exacerbated a landscape of fear between residents of gated colonies and urban villages, as well as desire (Srivastava, 2015). While middleclass and affluent newcomers occasionally clash with Gurgaon's original inhabitants, 
they also present an image of urbanity and conspicuous consumption to which the latter often attach a set of aspirations. Gurgaon's villagers still participate in a wider geography of rural and peri-urban life (Srivastava, 2015; Narain, 2009), but in contrast to the rural-urban migration strategies among wealthy rural landowners in Haryana and Uttar Pradesh (Jeffrey et. al, 2011), the landlords of Gurgaon have anchors in the city as is. Beyond simply resting or resisting in place, these actors have played a pivotal role in enabling Gurgaon's urbanization story and continue to shape its political landscape. While Cowen (2015) argues that state informality has allowed a "space of exception" within the village for the default sovereign actors (villagers) to remain in power, these sovereigns have also made attempts at legitimation, transmigrate from a shadow panchayat system into formal elected office and the visible politics of the city at municipal and ward levels. As a formerly rural place, the urban village holds memories of its older self, now facing a more dominant language of urbanization. But as the oral histories of the Yadav household and the accounts of Chapter 2 suggest, the clash between local groups and outsiders, and the simultaneous assimilation of and resistance to change, has been a continuing part of the lived experience of Gurgaon district long before the city's urbanization took off.

Gurgaon has now also seen a generation of adults, the children of urban villagers, come of age amidst its urban transition. The villagers interviewed here held a simultaneous sense of ownership as well as a sense of being an outsider in their own city, hoping to integrate into the ranks of a more globalized middle-class milieu. By maintaining their electoral majority, villagers balanced power against an existence as landlords in underdeveloped pockets of the city. In managing these conflicts, village 
landlords have alternated between victim and villain in local narratives of rural displacement, and re-emplacement. Many of Gurgaon's urban villagers have retained ownership to some of their lands, while becoming partners in DLF's development ventures. They have been the beneficiaries of capital accumulation, as individual households, but now find themselves, consistent with broader claims about such processes (Harvey, 2004), dispossessed from public goods and services once available to them through local governance and collective ownership. The contrast between the struggles of the landlord and their children, highlighted in this chapter, clarifies the salience of the attachment itself over the economic compensation debacle at the beginning of this story. While more educated than their parents, the children of this story were still conscious of their class separation from their neighbors in DLF housing, but also more inclined to value the difference over the village itself. In some ways the children were on their own search for place, and eager to establish their own shifting identities through urban space and place, to strike out, as is common, on their own terms and define how they understood their place in the world as distinct from their families and immediate communities. Whether they had internalized the millennium city narrative or found another one, their search for emplacement in Gurgaon was as important a project as their parents' fight to preserve their own. 


\section{CHAPTER 6: MIGRATION AND URBAN CITIZENSHIP}

\section{Introduction: A Journey to the City and Back Again}

"All citizens have the right to move freely throughout the territory of India; to reside and settle in any part of the territory of India". Article 19, Indian Constitution.

"It's inevitable and then people learn the ropes of democratic politics as they go along. In India, the lines are very blurred. There is still a sort of feudal undercurrent. And especially in rural politics and Gurgaon being urban but having large pockets of rural society...that's still very much the way politics runs. The urban population in Gurgaon is a migrant and floating one."

-Naik, Interview 2015

Sudhir had been in Gurgaon for 6 years. At age 18, he left his village in rural Bihar for Delhi to finish his schooling and learn to use a computer. He eventually found a job as an Administrative Assistant for an NGO just beyond Silokhera Village in Gurgaon. On a typical day, back in his family's home in Nadha, he would get up around 4:30 am or 5 to help with farming chores. As an Admin in Gurgaon, his day began at roughly the same time. He woke in the office where he worked, ran errands, collected the day's post, took his scooter to his boss's house, came back and opened the office, turned on the AC, and fired up the computers. One of the benefits of working here was that he could use them. At the end of the day, he prepared his food and got ready to repeat the cycle.

On trips home, he spent almost 24 hours reaching his family's house by train, then bus, and a $5 \mathrm{~km}$ walk. He felt buoyant making this trip. The anticipation of going home anesthetized him to the discomforts. Ten days in the village pass too quickly, and the journey back to the city seemed to take twice as long. Since he moved to 
Gurgaon and started sending money back, Sudhir's family has been able to build a new house with a concrete roof that didn't leak and keep them awake at night during the monsoon. When his father was sick a few months back, he was able to pay almost half of the hospital bill up front. But he sighs when he thinks about what it will cost to marry off his sister, almost 3 lakh rupees for the dowry, the appliances, a new fridge and the wedding itself. His plan was to educate her first, before having her married, no matter what neighbors in the village said about it, and eventually find a wife of his own.

Sudhir is one of hundreds of thousands of workers in Gurgaon who lead a dual life. His day to day occurs in Gurgaon. His work and housing are combined into a continuous reminder of why he is there: to earn. He might spend, every now and then, going into Delhi with friends or to the cinema, but the pair of jeans he could buy in Gurgaon would be a fraction of the cost in Patna, so why bother? His responsibilities to family, his long-term plans and aspirations and recognition as an Indian citizen lay back home in rural Bihar. He missed the air in his village. He dreaded the unhappiness his family experiences when he leaves. After more than half a decade in Gurgaon, he still considered himself a migrant.

Sudhir admitted that he did not share bad news with his family. His reports of life in Gurgaon were largely positive. Despite the real challenges and disappointments of migrant status there was also a world of concealment, storytelling, and face-saving, as one group left and came back, downplaying the difficulties they faced and perpetuating movements in which "new migrations follow the previous paths based on 
false promises or exaggerated portrayal of opportunities for employment" (Sheppard, 2009).

Chapter 4 discussed the challenges of incorporation, belonging and placemaking for middle-class, predominantly home-owning, migrants in Gurgaon, while Chapter 5 explored the urbanization of Gurgaon's ancestral villages and landowners. This chapter shifts to the circumstances for the urban poor, for whom the term "migrant" becomes a stigmatizing obstacle, rather than a badge of pride. Whereas the previous chapter dealt with the ancestral Villagers of Gurgaon, and fears of exclusion or irrelevance among Haryanvi communities, this chapter emphasizes the foreignness of the village, and its fringes, as the long-term, yet temporary, home for migrants in Gurgaon. The politics of the city highlight tensions between two rural constituencies, one local, and others "foreign". The conflicts and patronage relationships between these groups speak to national trends, including declines in agricultural production, India's urbanization, and widespread fear of or discrimination against Indian nationals from poorer states and religious minorities. Gurgaon highlights the growing prevalence of working-life migration strategies in India, the practice of keeping a foot firmly in each world, where migrant households reconfigure habitation and consumption practices "to remain located in both the urban and rural spheres" (Kantor, 2018).

Neighboring Delhi's urban poor invest the most hope in urban improvement in political parties (Harriss, 2005). In new towns such as Gurgaon, however, the predominantly migrant working poor, lack access to long-standing networks for slumdweller solidarity, organized labor or more common political clientelist relationships 
that often exist between politicians and the low-income voting majority. In the purportedly neoliberal or new Indian city, how do the urban poor make do? What is their connection to place? How might the radical acceptance of precarious living, and the simultaneous attachment and investment within both "urban and rural spheres" affect the nature of place and planning in the city?

As a city of migrants, Gurgaon's planning and urbanization cannot be understood outside the context of internal migration discourse. In this regard, Gurgaon presents a case study or object lesson in what Murphy (2006) refers to as the simultaneous "economic acceptance" and "social rejection" of domestic migrants in a globalized urban economy. One's place of origin becomes imbricated with identity and forms a basis for discrimination as well as the reinforcement of place-based attachments, as the sending region becomes a life-raft for one's eventual escape from the city.

To a certain degree, lower income migrant invisibility is enforced by the politics of village landlords, who depend on tenants for income, but also fear political displacement should outsiders achieve the right to vote. This fear is fueled by the particularities of place, including Haryanvi caste politics, i.e. how citizenship is constructed and governed in Gurgaon's urban villages and the city more broadly. As argued in the previous chapter, village landlords hold the political majority in the city's elected positions yet operate from the perception of second tier citizenship or class and cultural backwardness. This sense of second-class status is fueled by encroachments on village territory, a lack of adequate public services, and the cultural dislocation created by Gurgaon's urban globalized middle-class narrative. Combined 
with fear of migrant populations overtaking a political majority, local communities experience threats to place from above and below. The suppression of Gurgaon's actual population statistics, however, conceals the material needs of the village (as discussed in the previous chapter), which remain in a cycle of underdevelopment.

Gurgaon's original inhabitants and the cultural politics of Haryana's formerly agrarian communities also shape the perceptions and treatment of migrants in particular ways. For example, Muslim Bengalis in Gurgaon experience discrimination and self-selected segregation, combined with linguistic isolation. It is important to address and reflect on how local groups, as rent collectors and village overseers, resist the outsider or find ways to accommodate them in narratives of re-emplacement.

This chapter is informed by interviews and oral histories with approximately 120 households living across four of Gurgaon's urban villages, including Sikanderpur, neighboring Chakkarpur, and two others closer to the center of the city. A near universal refrain among participating households: "we will go back, but not yet." 181 Experiences of urban invisibility, discrimination and hardship in the city were weathered and seemed to reinforce place-based ties to home. ${ }^{182}$ Gurgaon is an attractive destination for migrants seeking to diversify incomes beyond agricultural production, but income alone is not the basis for an attachment to place or the desire to put down permanent roots. Ownership, as discussed in previous chapters, is a more salient indicator of a deeper investment in place. We carry places with us, such that

${ }^{181}$ While Oldenburg's (2018) interviewees quickly disabused her of any romantic notions of life in the village, this diverges from my finding across four urban villages. Nearly all reported their intention to return home when they could no longer work.

182 It was not uncommon for participants to explain that their quality of life in Gurgaon was not materially better than the village, despite their increased income. 
putting down roots in a new location requires acceptance and renegotiation of the self in relation to other attachments and other places (Scannell \& Gifford, 2010). These processes can be resisted, interrupted, or countered. One of the central questions that emerged from these conversations was how families made the calculus to accept minimal access to local benefits, or recognition as urban citizens, to preserve an attachment to another place? Why is it that Gurgaon's narrative, the one suggested by Crestani's photos, does not translate into a more permanent kind of aspirational vision for the working-classes? In exploring this question, this chapter also documents the conditions of living for low income migrant workers in service and labor professions, who often come to Gurgaon "short term" yet stay for decades at a time.

Ultimately, this chapter looks at conflict or the perceived conflict over place in Gurgaon's urban villages and seeks to trouble the notion that migrants lack a sense of belonging. I argue that while the images of wealth and prosperity associated with Gurgaon's fictional urbanism and central place narrative, in Chapter 2, are on full view and present an aspirational vision of place to migrants, they do not have the same significance or meaning for the urban poor as they might for those who are socioeconomically closer to achieving the vision, such as the lower middle-classes or the educated adult children of Urban Villagers. Gurgaon's reputation presents a kind of hope, but low-income migrants enter the city from a different perspective, through the service elevator so to speak, as workers, servants, and laborers, with a sense of the struggle they are about to face. This is understood through word of mouth, even when those claims may be exaggerated. The act of placemaking, amid the challenges that migrants face as outsiders, is complicated by treatment in the receiving location, and 
the strength of place-based relationships and attachments to the sending region. Attachment to or a sense of belonging to a place does not require one to be in constant contact with the source of that attachment (Scannell \& Gifford, 2010). Sending remittances, investing in the welfare of a rural village, participating in politics and familial relationships maintain those place-based relationships precisely by the temporary act of leaving them behind. Conversely, to achieve a sense of belonging, and one's place in the city, requires more than established shelter, long-term residency and local wages. Even with the whole family on location and children in the city's schools, the migrant households surveyed in this chapter still viewed their moves as temporary. The chapter unpacks the material and affective explanations for this strategy, a form of adaptation that is both innovative but also deeply conservative.

\section{Internal Migration and Urbanization in India}

Domestic migrants in India number the hundreds of millions. ${ }^{183}$ While migration is a pervasive and heterogeneous process, it disproportionately burdens the poor, who are already more likely to move due to the distress of poverty or near poverty in rural areas. Since the 1980s, India passed the $30 \%$ urban mark in states and cities with the highest GDPs and human development indicators (Tumbe, 2016). ${ }^{184}$ For

${ }^{183}$ According to UNDP's 2013 estimates, there are nearly 700 million internal migrants in the world, compared with just over 244 million international migrants globally Migration and Displacement, UNDP. Meanwhile, according to the 2001 census, there were over 300 million internal migrants in India. This figure has increased by over 100 million in the 2011 census. Overview of Internal Migration in India, UNESCO, 2015, Census of India 2001 \& 2011. ${ }^{184}$ There is reason to argue that India's urbanization rates are also skewed by the way in which rural and urban destinations are defined. For example, there is a relatively large 
example, Kerala and Tamil Nadu are 40\% urban compared with Bihar and Orissa (roughly 20\%). ${ }^{185}$ The proportion of India's population living in urban areas, however, is often vastly undercounted due to the movement of temporary workers (Tumbe, 2016). The benefits of India's floating labor force are accrued in both sending and receiving locations as migrants meet the demand for low-wage labor in service and construction, while sending remittances to their home states without receiving local subsidies. ${ }^{186}$ Often low-wage migrants are not landless peasants, but share land within their extended families. ${ }^{187}$ Traveling to cities for employment as seasonal laborers in construction, manufacturing and other professions has become part of a welldocumented rural income diversification strategy.

Since Gurgaon began to urbanize, migrants have come, predominantly from Bihar, West Bengal, UP and Rajasthan, as construction or seasonal labor, with a growing number of families. ${ }^{188}$ In contrast to the pattern of the solo male laborer in the

population threshold in India for "urban", greater than 5,000 residents within a certain area. Were many of India's "census towns" to be reclassified as urban, the country's urban population would be much closer to $50 \%$. India may be more urbanized than its statistical units indicate.

${ }^{185}$ Between 2001 and 2011, India's urban population grew on average by 4\%, while Gurgaon's population increased almost 50\%.

${ }^{186}$ India's domestic remittance market was roughly \$10 billion in 2007-2008 (Tumbe, 2016).

${ }^{187}$ While natural increase (births) in cities has declined, birth rates have risen more significantly in rural areas, particularly in poorer states (Tumbe, 2016).

${ }^{188}$ The increasing demand for service labor has altered traditional internal migration patterns. Men outnumber women in India (943 females per 1000 males, 2011 Census), but the divide is profound in cities where men have tended to outnumber women two to one. The visibility of solo male migrants in Gurgaon, day laborers, construction workers, street vendors and so on, observationally confirms these statistics to some extent. The solo-male migration story upholds a gendered view of the household division of labor, in which women remain in the village, while male migrants seek employment in the city, send remittances home, and carry on as legal residents of rural districts. While women overall do comprise $70 \%$ of internal migrants in India, when women migrate, it is primarily for marriage. When men migrate, it is for work (Kaur, 2004). 
Indian city, the presence of whole families counters the narrative of the village as the place where women and children are left behind. As the demands for labor have shifted from an industrial and construction base to service needs, women laborers are also in demand as cooks, maids, security personnel, and school helpers. In Gurgaon, where up to $80 \%$ of low-income migrant households originate in West Bengal, children are also brought to live alongside both parents and attend local schools.

To be an internal migrant in a developmental state, such as India, can become an ordeal like that of being an undocumented foreigner abroad (Abbas, 2016). For the most vulnerable, providing proofs of identity and navigating Indian bureaucracy requires the coordination of various skills, the expenditure of resources and a tremendous amount of patience. The bureaucracies that throw up this red tape may help to perpetuate discrimination and structural violence against the poor in India, the intended beneficiaries of state welfare programs (Gupta, 2012).

Indian citizenship, as an administrative practice, has a contentious history beginning with the movement of millions of refugees at independence (Abbas, 2016). At first, widely inclusive, Indian citizenship was granted to Hindu and Sikh refugees in the post-partition era. This liberality seized up in the 1970s with Bangladesh's independence and ongoing conflicts in Sri Lanka, when a new wave of refugees had to be contended with. Years of agitation against migrants were addressed in the Assam Accord of 1985, although discrimination toward Muslim Bengali speaking Indians also rose dramatically in North East India and has continued. Suspicion of foreigners increased, as did administrative attempts to clamp down on migrants entering India's 
borders. This has had unforeseen effects on internal migration as well. ${ }^{189}$ Efforts to curb or block certain illegal migrants have inadvertently created illegals of rightful Indian citizens.

As a political designation, citizenship asks for certain rights to be upheld and needs to be met that are often impossible for the State to guarantee. The difficulty in passing the tests to qualify for those benefits, in some ways, shields the State from reckoning with its shortfalls. This tussle over who gets what or the fear of losing scarce resources to "outsiders" means that citizenship is often something negotiated, not at top-level State institutions, but among the quasi-administrative gatekeepers of different ethnic and linguistic groups in small places, and through smaller administrative subunits in bigger places, i.e. cities.

Citizenship is not just a legal or political designation, but a socially and culturally constructed institution (Benhabib, 1999). The successful movement and integration of migrants into a new locale requires the presence of migrant networks and what Sadiq (2008) refers to as "blurred membership", to support migrant dealings with weak state institutions. In India, there is some instant legibility in terms of one's identity and place of origin through language, name, socio-economic status, education, and caste affiliation. This evidence allows locals to assess and socially categorize and emplace a potential tenant or employee, and this knowledge informs how they treat or respond to them. Familiarity with these social and place-based markers blurs and

${ }^{189}$ A constitutional amendment was passed in 1987, determining citizenship through jus sanguinis (blood). To be considered a citizen, one had to be born in India and have at least one parent with Indian citizenship at the time of birth. This was eventually amended in 2004 to include terms that one parent was a citizen, and the other was not an illegal immigrant in India at the time of birth. 
becomes less clear when migrants arrive from a greater distance (blurred boundaries). Weak institutions that fall back on strict proofs of citizenship allow for blind spots, in which illegal immigrants might benefit, while creating barriers to the intended beneficiaries of state assistance (Sadiq, 2008).

Citizenship in India, then, becomes a cultural and place-based institution that can be withheld using the tools of the state. Skepticism and suspicion of government institutions, as well as narratives of corruption, already cloud expectations that programs will reach all their intended beneficiaries (Gupta, 2012). Nationality’s burdens of proof (Aadhar, voter ID, etc.) provide a simple condition for denying urban citizenship. Without urban (or local) citizenship, migrants cannot claim public benefits from the state. In the day-to-day, this means living without access to subsidized food, housing, drinking water, sanitation and public health facilities in the receiving location. First generation migrants also tend to have low levels of education, with limited access to banking services and often work in poor conditions without social safety nets or legal protection. To be poor in India presents its own set of vulnerabilities, to be both poor and a migrant, becomes a significantly more precarious form of second-class citizenship (Abbas, 2016).

\section{Local Discrimination and Tenant Suppression}

Work on migration in Indian mega-cities observes how location-specific historical or political movements and cultural norms shape the reception of migrants. In Mumbai, for example, the local politics and dominance of the anti-migrant, Hindu Nationalist Shiv Sena, resulted in targeted violence towards migrants in 2008. By 
contrast, migrants experience different outcomes in the slums of Kolkata, despite the lower GDP for the city as a whole, where "unlike Mumbai, Kolkata does not have a strong strain of nativist politics" (Abbas, 2016, p. 157). ${ }^{190}$ Gurgaon's original inhabitants and the cultural politics of Haryana's formerly agrarian communities, also shape the perceptions and treatment of migrants.

In interviews with landlords in Gurgaon's urban villages, negative perceptions of migrants from specific sending regions and states were not concealed. A local, who now runs a skills development center for migrants reflected, "when I was in school and college there was a time when anybody used to just slap a migrant." ${ }^{191}$ Bullying and physical violence towards migrant tenants was an observable issue during fieldwork, but appeared to be site specific. Individual families and landlords garnered reputations, some more menacing than others. Yet the more subtle and pervasive forms of the "slap" continue to play out in the dealings between landlords and their tenants, employers and employees, migrants and local government.

The biases that can determine whether a landlord will accept a potential tenant are compounded by the ways in which landlords view tenants coming from specific places. Several landlords described the process for obtaining a rental, in which documentation was required for new residents if they were from foreign countries, such as Nepal and Nigeria, or from Bihar and Orissa. Bihar and Orissa happen to be among the poorest states in India, with high rural population percentages (Tumbe,

\footnotetext{
${ }^{190}$ Abbas suggests that Kolkata's legacy as a post-Marxist city has produced a culture that discourages pointing out ethnic differences that would have historically undermined the struggle of workers.

${ }^{191}$ Interview with the Director of Agrasar (2015).
} 
2016). Bihar is also one of the largest sending states, with migrants heading primarily to Mumbai, Delhi/NCR, and Kolkata. The stereotype of the Bihari distress migration pervades landlords' imagination and stokes fear that migrants from more economically distressed states will have little incentive to return home.

Conversely, a negative perception of Urban Villagers was shared by newcomers across the socioeconomic spectrum, views that were sometimes reiterated by Villagers themselves. Not only were views of others deeply aligned with a place of origin, and all of the cultural and linguistic associations with that place, they could also perpetuate barriers by reinforcing mutual suspicion between landlord and tenant, who represent to one another, not just an imbalance of power, dependence and class relations, but a clash of identities and competition between historically marginalized agrarian identities. Despite the language of India's constitution, citizenship, in these instances, functions as something immobile and deeply linked to location. While the majority of participating migrant households in this research reported they did not intend to permanently settle in Gurgaon, even as they spent a good portion of their working lives contributing to Gurgaon's economy, and sending their children to local schools, the fear of their permanence among an older generation of Villagers was still operational. As the landlord in the previous chapter admitted, however, the invisibility of Gurgaon's migrant population concealed the material needs of the village, the de facto informal and affordable housing for the city. 


\section{The Urban Village: Migration and Working Life}

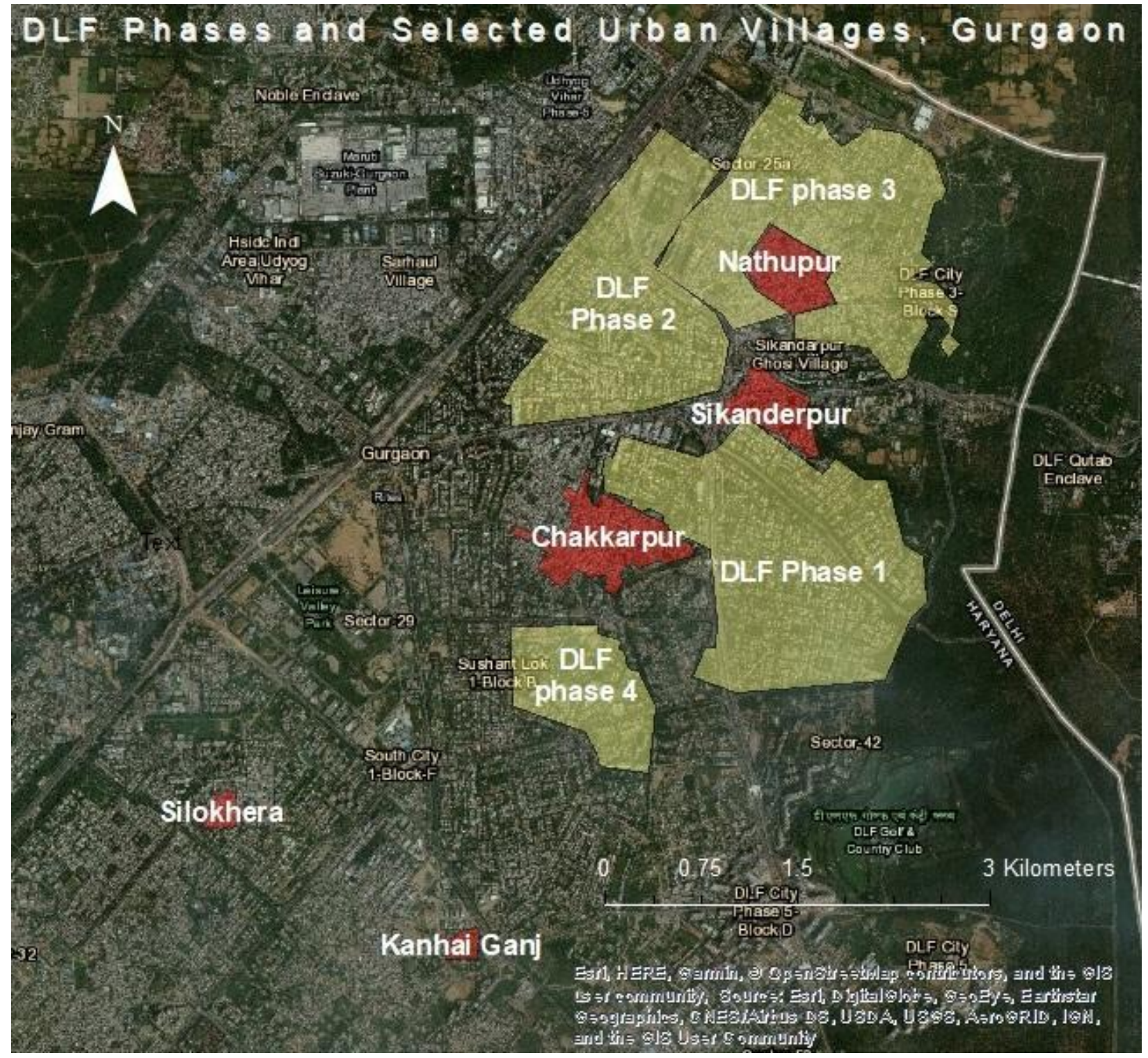

Figure 18

Although Gurgaon is a "receiving location", not all migrants experience the city in the same way, or as a single place. Where one comes from (sending region), the type and size of household, type of employment, education and many other factors 
funnel newcomers on paths into different enclaves and living situations. These multiple places and lived realities may coexist or overlap within a city known for spaces that are infrastructurally fragmented, but socially, politically, economically, and ecologically entangled (Srivastava, 2015). Furthermore, most of these households work outside the village, and experience an entirely different kind of built environment as employees, predominantly in domestic service work. The villages and households discussed in this chapter, Chakkarpur and Sikanderpur (82 households combined), Silokhera (15), and Kanhai Ganj (15) are situated near or shared municipal wards with DLF or Ansels housing. These households have chosen the village for its proximity to employment within walking distance. 


\section{Gurgaon Urban Villager States of Origin}

(Participating Households across four urban villages)

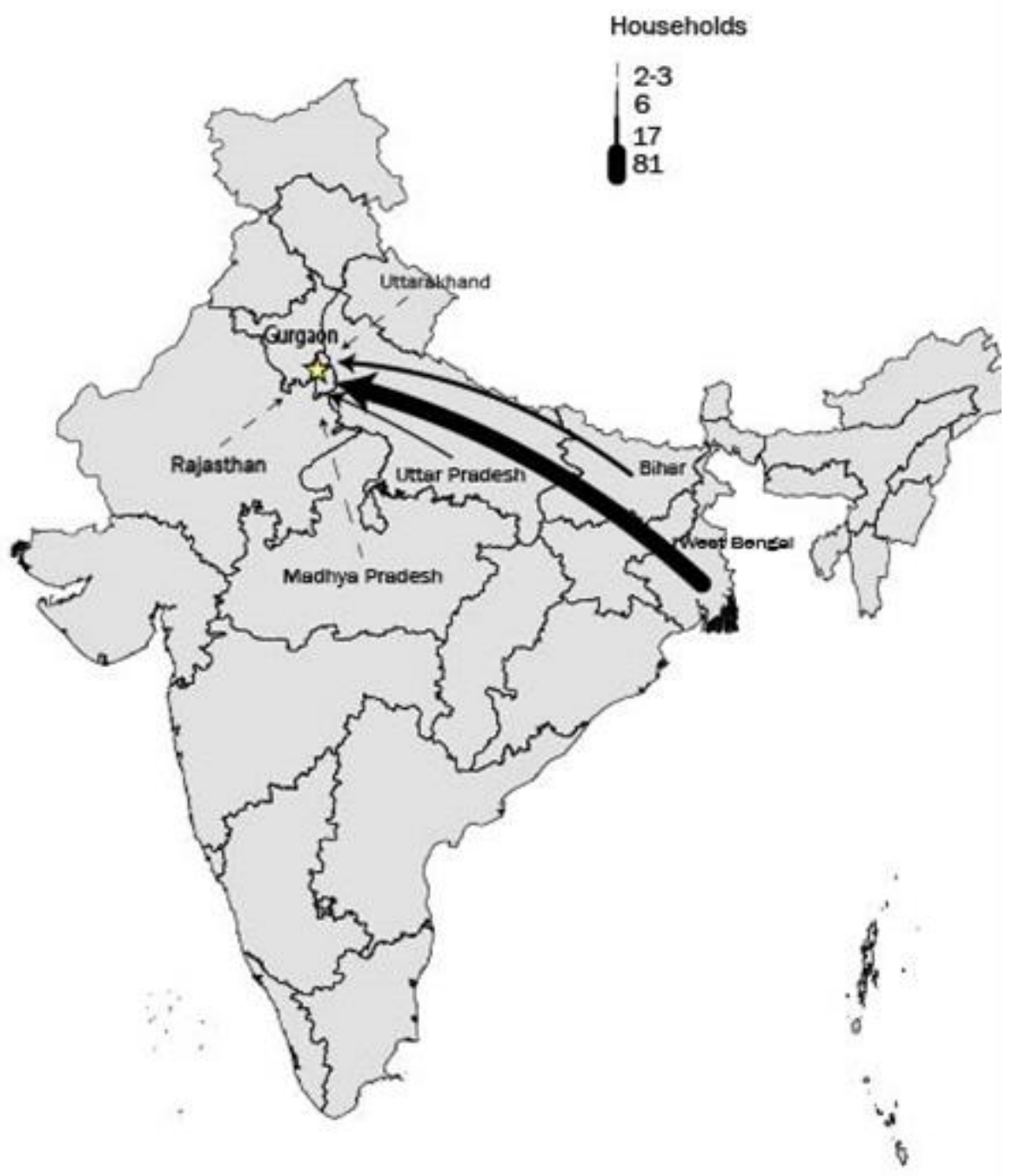

Figure 19 
Table: Migrant population of select urban villages in Gurgaon, as of 2015

\begin{tabular}{llll} 
Location & Total Population & Migrant Population & $\begin{array}{l}\text { Dominant State of } \\
\text { Origin }\end{array}$ \\
\hline Central Gurgaon & 200,000 & $120,000(60 \%)$ & Bihar \& UP \\
$\begin{array}{l}\text { Sikanderpur, } \\
\text { Nathupur }\end{array}$ & 200,000 & $160,000(80 \%)$ & West Bengal \\
$\begin{array}{l}\text { Chakkarpur } \\
\text { Silokhera, Kanhai }\end{array}$ & 50,000 & $36,000(90 \%)$ & West Bengal \\
$\begin{array}{l}\text { Ganj, Wazirabad } \\
\text { Gang }\end{array}$ & & $30,000(60 \%)$ & West Bengal
\end{tabular}

Source: Agrasar ${ }^{192}$

192 At the time of fieldwork, at least three of the villages had already participated in population surveys through local NGOs. As of 2015, Sikanderpur (combined with nearby Nathupur village) had a migrant population of close to 160,000 . Chakkarpur had a migrant population of 36,000, while Silokhera and Kanhai, had less than 30,000 migrants (Agrasar, 2015). The 2011 census no longer lists the individual populations of villages, as they have been incorporated into municipal wards. The 2001 census, however, listed Sikanderpur village as having a population of roughly 5,000-6,000, a difference in the tens of thousands of residents. The reasons for focusing on Chakkarpur and Sikanderpur had much to do with their location and size. They constituted two of the largest urban villages and rental markets for low income migrants in Gurgaon but were also. Chakkarpur was also the site of the first land deals between DLF (KP Singh), and local farmers in the late 1970s, and has witnessed some of the catalyzing moments in Gurgaon's urban origin story. Silokhera and Kanhai Ganj were more centrally located within Gurgaon. Kanhai Ganj was not far from Silokhera but had a reputation for comparatively poorer living conditions. Silokhera was close to HUDA City Centre, the last metro stop on Delhi's intercity rail, and was also the location where a partnering NGO's ties to migrant communities in that village allowed us easily pilot interview questions and protocols. An education NGO, Aravali Scholars, was also based in Sikanderpur Village, and employed migrants as teachers, and assisted with participant recruitment in that village. 
While villages were palimpsests to their ancestral inhabitants, who witnessed decades of growth, change, and reinvention, these spaces had less resonance as housing, a place to sleep and bathe, for newcomers. The majority of participating households were originally from West Bengal. ${ }^{193}$ This constituted the largest single diasporic group to emerge in the interview process. ${ }^{194}$ Migrants from WB usually came together as a household and worked as a unit to achieve specific outcomes, notably from 3-4 low-income districts in rural WB. ${ }^{195}$ Many were the descendants of earlier migrations from Bangladesh (East Pakistan) to India in the previous generation. While land was owned within these families, beyond farming activities, there were few local opportunities for employment. Migrating to Gurgaon had become part of a shared strategy among an extended family, where one or several siblings and parents, stayed home to cultivate and maintain shared property. ${ }^{196}$

Reasons for migrating to Gurgaon were consistent with established theory on migration (Harris-Todaro, 1970; Sassen, 1988). Every participating household cited

\footnotetext{
193 Over the Spring of 2016, over 120 households were interviewed (encompassing a total population of 450). The average household had 4 members, (as low as one, as many as 8). Besides West Bengal, 17 households were from Bihar. Five were from Uttar Pradesh, three households from Madhya Pradesh, two households from Rajasthan, and two from Uttarakhand. The predominance of Bengalis in the overall population was verified by local NGOs (see table 1).

${ }^{194}$ Solo male migrants in Gurgaon tended to come from UP, Bihar, Uttarakhand, Rajasthan, and MP.

195 There were some exceptions among WB households, where children were left behind in the village with relatives. This strategy raised concerns among migrant NGOs, however, because it appeared to maintain education levels intergenerationally, instead of advancing them. The children of these migrants would potentially end up achieving the same quality or level of education as their parents. In contrast, with migrants from Bihar and UP, the cycle usually began with remittances, but as children grew older, they were brought to Gurgaon to attend private schools. Interview with Director of Edulever, 2015.

196 This was confirmed by interviews as well. A significant number of WB participants stated they had come from Malda District.
} 
income and employment opportunities as a reason for shifting to the city. The stories of how and why Gurgaon was chosen were also consistent with the literature on migration networks, where the reputation of a specific receiving city was carried by word of mouth, creating a deep and well-worn migration track or snowball effect over time (Massey, 1999). These strategies were also shaped by the sending region and the type of labor sought. The "cost differential model", for example, explains why migrants in Gurgaon tended to fall somewhere between lower middle-class and extreme poverty. The reason for this is that while labor opportunities pull migrants, migrations themselves are costly, and require some economic means to undertake (Stark \& Bloom, 1985). However, there were also several instances of "distress migration" among participants, where the economic conditions in the sending region were so dire that migration was the only option. ${ }^{197}$ In these cases, migrants reported they intended to stay in Gurgaon indefinitely.

The most labor intensive and dangerous types of work, with on-site living in construction and manufacturing, were performed by solo male migrants. While Gurgaon's original Maruti factory had moved and become automated, its proximity to Gurgaon fed a smaller industry of third-tier auto-parts manufacturing workshops, employing about 80,000 laborers (predominantly young migrant men) at any given time. These laborers tended to live and work on workshop floors, what local NGOs refer to as "captivity situations," in which workers rely entirely on an industrial employer for both wages and housing. Unable to "escape" the job, they take on longer

${ }^{197}$ Distress migration is characterized as bordering on forced migration and occurs due to extremely dire economic conditions in the sending region. Source: "Distress Migration", Food and Agriculture Organization of the United Nations (FAO). 
or back to back shifts. While the unending labor of live-in domestic staff poses emotional and material hardships to workers, operating auto-parts manufacturing machinery without safety devices involves another order of risk. Exhaustion, combined with the pressure to earn and meet quotas, makes workers more vulnerable to injury. Hundreds each year suffer traumatic crush injuries operating machines in these smaller workshops and are forced to return home to their families, often with permanent disabilities that dash their hopes at marriage or capacity to perform rudimentary agricultural labor. The dangers of this kind of work are compounded by the precariousness of migrant status without local citizenship. Employees who lack local ID or access to worker insurance programs, for example, can only find care at selected hospitals or clinics across the city, lowering the chances of recovery or positive outcome in the event of a catastrophic injury. ${ }^{198}$

In addition to manufacturing, construction was also large employer of solo male migrants. Much of the construction labor in Gurgaon is from Rajasthan as well as Madhya Pradesh. On larger construction projects, a temporary colony might spring up, allowing for entire households to move in. The youngest workers tended to be 15-16 years old, while retirement began around age 35 , largely due to the physical toll of the work. Construction laborers worked with employers on contracts for a period of a year or two in each location. It was not uncommon for workers to sign their resignation when they began a contract, or move with the job to various sites, often with the same contractor. ${ }^{199}$

\footnotetext{
${ }^{198}$ Interview with Director of Agrasar (2015).

${ }^{199}$ During early morning trips to urban villages, it was common to see day laborers clustering
} 
The bulk of secondary labor force opportunities in Gurgaon, however, are service work in gated colonies, high rises, malls, office parks and commercial centers. The occupations most common among participants included drivers, rickshaw pullers, press-wallas, maids, gardeners, cooks, security guards and caretakers, or in cases such as Sudhir, aids who manage an office, run errands, and serve as interlocutors with the support staff in an office (cooks, maids, etc.). The demand for service sector work also meant a demand for female labor, such as female security guards, cleaning staff, and school staff (another factor contributing to the full household migration strategy). ${ }^{200}$

As observed with construction labor, recruitment for work might occur through specific networks and geographies. For example, many of the skilled low-wage laborers, who worked in textiles or construction specializations, such as masonry, came from Uttar Pradesh through particular networks. ${ }^{201}$ With declines in agricultural production, rural-urban migrations also shaped new paths of professional specialization associated with specific states (plumbers in Gurgaon were predominantly from Orissa). These kinds of networks have allowed migrants from specific states to find training and acquire new skills once they arrive. According to a local NGO organizer:

"If you go and visit certain blocks or certain villages in Bihar, UP, or Rajasthan, you come across phenomenon where the entire village is now living in just

under flyovers at the entrance to the village, waiting for contractors to arrive and recruit for short-term projects.

${ }^{200}$ Staff positions in schools do tend to go to locals and migrants from adjacent regions, interviewee cited education deficits as an explanation. Migrants from UP and Bihar tend to be less educated. Recruitment for certain jobs, such as school staff, tend to happen locally, through Haryanvi networks.

${ }^{201}$ Massey's (1999) discussion of cumulative social networks: the greater the number of former or present a person in a sending area knows, the greater the probability that he or she will also migrate. 
one colony in Delhi...I can remember going to this village in Lucknow... almost all of them work in this area in east Delhi called Mandawali as carpenters."

In addition to income, about a quarter of participants also cited education (for their children) as a reason for migrating, although this was usually in addition to income and employment opportunities. The educational profile of the average adult migrant participant was 7 th level, i.e. basic literacy in their native language, fluent but not entirely proficient in Hindi (if it was recently acquired), and no English language education. $^{202}$

Several participants, the children of migrants from West Bengal, were also students and instructors with a local NGO in Sikanderpur. The other practical benefit of this strategy was that it meant once children reached a certain age they could also contribute to the household as educated workers. In their late teens, the part-time assistant teachers I interviewed were still finishing their schooling while bringing in wages that exceeded those of their parents.

The preference among middle-class and affluent households in Gurgaon, as well as among low-income migrants, was to send children to private schools, preferably schools that offered English instruction. Government schools, even among workers with the lowest earnings were regarded as a last resort. However, this also posed a dilemma for households from West Bengal, where the decision to educate one's children in Hindi and English could mean sacrificing Bengali language instruction, an important aspect of maintaining ties to home for the next generation.

\footnotetext{
${ }^{202}$ Participants observed that private schools of the same quality as the ones in Gurgaon in or near Kolkata and surrounding areas, would have been more expensive for their families. It was more affordable to attend private schools in Haryana.
} 
While the concept of seasonal migration often describes temporary migrations in India, particularly in those instances where migrants spend part of the year engaged in rural or agrarian labor, the term does not capture all realities. In interviews, participating households reported an average of 120 months in Gurgaon, or 10 years. Invariably the households with children had been in the city for a length of time that corresponded to the age of the oldest child. Those who were more recent arrivals tended to be in their early to mid-20s, often with small children who had been born since the move.

For those who could afford it, journeys back home were annual and took place for important events such as local elections or the birth of a child. Free treatment in the home village or region, access to relatives for convalescence and childcare, combined with general distrust of local doctors in Gurgaon were cited as reasons for returning to the village to give birth.

In all interviews, participants were asked whether their move to Gurgaon would be temporary or permanent. Nearly $75 \%$ said they would eventually return to their home village, though most said, "not yet," estimating a few years, some as many as a decade, before they would begin to seriously consider it. This reflected a perception of Gurgaon as a place in which to work, but not to retire. Participants often mentioned some land owned by their extended families that they might eventually return to. Their savings would have more buying power back home when they reached a stage where they were physically unable to work. The households who reported they would permanently settle in Gurgaon were often landless or distress migrations, or came from closer sending regions, such as Rajasthan and UP. The prospect of "going 
home" in these cases meant a bus ride of a few hours, more of a commute than a longterm relocation.

\section{Documentation and Discrimination}

The right to move domestically is clearly stated in India's constitution, alongside protections for lower caste and historically disadvantaged groups, yet the ability to benefit from these protections also hinges on being recognized as an Indian citizen. ${ }^{203}$ Providing adequate forms of identification presents the greatest challenge for the very groups most in need of government assistance. Identification is also required to seek employment in the formal sector, a prerequisite that limits economic mobility among those who can't produce it. Migrants are subject to the directives and interpretation of the law among local bureaucrats and administrative gatekeepers and the politics of the receiving region or city. Small measures of obstruction, a local administrator asking a migrant to come back the next day, repeatedly, or only offering ration card applications in the local language, add up to a cumulative resistance to migrant incorporation (Abbas, 2016). ${ }^{204}$

Most participants in the research had a voter ID card, Aadhaar card, or ration card from their state of origin. Aadhaar and ration cards were used as proof of identity

203 The 1946 Objectives Resolution, or 'Fundamental Rights' section of the Indian Constitution.

${ }^{204}$ In Abbas's (2016) account, the West Bengal Government and the Kolkata Municipal Corporation routinely burn identity documents of residents of unauthorised slums when they evict them, including migrants from rural areas in WB, Bihar or Bangladesh. While the government has claimed the documents do not belong to Indian citizens, many of these cases involved slum dwellers who spoke Hindi and were clearly not Bangladeshi in origin. 
when seeking housing or employment. ${ }^{205}$ Ration cards were often used to obtain a voter ID card. ${ }^{206}$ Indian citizens are not allowed to maintain dual residency in two locations. If migrants were able to hold multiple residencies, the rationale goes, they might abuse public assistance by seeking benefits in multiple locations. However, the hurdles to changing one's official state of residence intimidate migrants who fear they will not be able to reverse the process or resume legal rights in their home village. The procedure is difficult enough to deter newcomers from considering a move to Gurgaon, even one of many years, as anything less than temporary.

While this preserves certain benefits and protections for these households, and relieves the fears of political displacement among locals, the temporary migration strategy ultimately harms not only individuals and households in the short-term, it stagnates the possibilities for planning and addressing some of Gurgaon's broader issues and fragmented infrastructure. Migrants are not counted in official census figures for urban villages, which are used to determine government supplied water and electricity, and officially classify villages as a $10^{\text {th }}$ of their actual size (in terms of population). The resistance to migrant incorporation in Gurgaon's villages does not always begin in a bureaucratic setting. There were abundant stories of village landlords preventing tenants from obtaining the paperwork they would need to claim local benefits and voting rights. None of the participants in the research had written

205 One way of obtaining local benefits is enlisting adult or teenaged children to obtain them. About 24 participant households had at least one member with a local Delhi or Gurgaon Aadhaar card, usually a younger adult member of the household.

${ }^{206}$ Ration cards enable access to government subsidized food stuffs and dry goods, a program going on for more than half a century that has now been altered and linked to the Aadhaar card scheme. Ration cards come in tiers, based on extreme poverty, at poverty and above poverty income status. 
leases. This was not always indicative of abuse, so much as standard practice (Naik, 2015). However, many landlords also lacked official deeds of ownership for the land they rented. Any contracts they might have produced would be legally void if ownership was investigated or contested. Furthermore, these ambiguous tenure arrangements, on the periphery of the village or on former panchayat land, were often involved in ongoing legal disputes. The construction of informal settlements on the ambiguous fringes of the village had meanwhile boosted the available surplus of lowincome housing to rent in an environment where migrants had few other options.

While landlords rely on their tenants' success and ability to thrive in the city, they also rely on their vulnerability. While having identification was useful, Naik observed, "I believe they will take the train journey all the way just to cast a vote and come back the next day. They'll do it because their allegiances are very clearly back in the village. If you give them a voter ID...they want it for the ID, but not because they want to vote in Gurgaon". 207

\section{The Cost-Benefit of Invisibility}

"They're completely disinterested in where they live how they live. It is not an issue for them. 20 families sharing a toilet, it's not an issue. If you probe, they will say it's a problem. But it's not the [main] problem."

- Interview with Naik, 2015

207 The Aadhaar card system was established in 2009 and is somewhat analogous to a social security card in the US, providing a unique identification number for each citizen, although there is a small percentage of the population that does not have one. While it provides basic proof of identification, it cannot be used as a passport or demonstration of Indian citizenship abroad. 
Throughout this chapter, I have referred to migrants as "low-income" in part to bracket the problems with the term "poor" as a label and as a government designation. The average income of a household in this chapter would not have been considered at or below poverty in India ( $\$ 1.90$ a day PPP according to the World Bank). ${ }^{208}$ Average incomes for households with more than one adult were 21,000 Rs per month (about $\$ 10$ a day). ${ }^{209}$ However, the Indian Government has been criticized for fixing its income threshold too low, a move that allows the government to claim millions of citizens have been lifted out of poverty over the past few decades. This achievement also happens to lower the number of beneficiaries for state entitlement programs. While incomes may have risen, the cost of living has also increased, and by any casual observance, and particularly in the context of an expensive city like Gurgaon, the average income of $\$ 10$ a day for a 4-person household, (considered middle-class by some measures), permits a standard of living that still reads as poverty. This is because, as Satterthwaite (2004) points out, assumptions about poverty are drawn from national averages, while the cost of living in certain locations might be significantly higher.

\footnotetext{
208 According to 2011 estimates, roughly $21 \%$ of India's population is at or below poverty level.

209 A monthly income of $\$ 330$, annually just shy of $\$ 4,000$. This puts a daily income of $\$ 10$. Rents tended to consume about $25 \%$ of a household's income, ranging from 2,500 to 3,500 Rs per month, with an average increase of 100-200 Rs per year. A little less than $80 \%$ of households had experienced a rent increase in the previous year of about $10 \%$. The average expenditure on education was 1,200 Rs per month, 5,400 Rs on food (usually higher than rents), 2,000 on health-related expenses, mobile phone charges and transportation. Average savings were approximately 4,000 Rs per month.
} 
Poverty is multidimensional, and the various deprivations associated with it are not solved by subtle increases in income alone (Baud et al., 2008). Satterthwaite (2004) has criticized an overreliance on the notion of the "poverty line" in developmental states and describes an index of poverty-qualifying deprivations that accurately apply to the living conditions of low-income migrants in Gurgaon: precarious access to employment, lack of education and stable or legal tenure (housing), inadequate access to piped water, sanitation, drainage, roads, lack of basic services, or alternative safety-nets, limited access to legal protection or advocacy for rights, as well as invisibility within a bureaucratic or legal system. While it is true that many households have opted to live as inexpensively as possible to add to their savings, increasing one's rental budget by a few thousand Rs per month does not improve the range of options above what is currently on offer in urban villages. Higher quality housing for migrants tends to be on site, if employers offer housing, or in tenements i.e. one room apartments, with shared water and sanitation facilities. By international standards, slums are the only affordable housing for workers earning roughly 20,000 Rs a month or double that figure. ${ }^{210}$

Due to the premium placed on private land in Gurgaon, the low-income rental market existed almost entirely in urban villages or on lands with ambiguous ownership. ${ }^{211}$ The combination of this housing situation and the high cost of

\footnotetext{
${ }^{210}$ UN Habitat (State of the World's Cities report) classifies a household is living in slum conditions if one or more of five criteria are met: inadequate or durable housing, lack of adequate living space (not more than 3 people sharing a room), lack of consistent and affordable access to clean water and sanitation shared by a reasonable number of people, and lack of secure tenure or protection from forced eviction.

211 Private lands that had not yet been developed, former agricultural land that existed as such "on paper only" or public land that had not yet been developed or surveyed by state and local
} 
transportation/lack of adequate public transit options, made the proximity between villages and middle-class residential enclaves vitally important to their interconnected economies. Homes in gated colonies often do have accommodations for servants. However, this space is often limited and insufficient for multigenerational migrant families. ${ }^{212}$ With the reliance on many forms of low-wage labor, from drivers, to cooks, to sweepers, security guards, and gardeners etc., it becomes impossible for a middle-class household to accommodate living quarters for the sizable labor force that contributes to the maintenance of a home throughout the day or week.

The housing options in urban villages were often originally auto-constructed settlements in former construction sites. A trail of basic amenities, such as tea stalls, might have cropped up on makeshift pathways between the site and the village. Once the temporary colony was abandoned, however, housing would become part of the stock of buildings and peripheral land for the village. Once the construction workers had vacated, domestic staff in the new colony would take up their housing. Villagers might rent the new housing to the next round of migrants, feeding an informal expansion of the village over a process of many years.

In villages, migrant housing usually takes the form of jhuggis, single-story brick and tin hut settlements with concrete or dirt floors, built on private land on the periphery. These hutments might share a toilet between 15-20 or more households, with no showers (and costs between 1,500-3000 Rs per month). On the lowest end,

\footnotetext{
agencies.

${ }^{212}$ In the case of many high-rise condominiums, a single spare room that would have been allocated to a servant in the original design of the flat is often converted into a home office or guest room, while help comes to complete short tasks like cleaning and cooking for a few hours during the day.
} 
several of the participants in Kanhai Ganj lived in a small encampment of tented rental plots (less than 1,000 Rs. a month), which had no access to water and sanitation facilities. $^{213}$

Closer to the center of villages like Sikanderpur, Chakkarpur, and Silokhera were more permanent, brick, multi-story tenement style buildings, with higher rents, and toilets shared by up to 15 households. These $p u k k a^{214}$ rooms were costlier, and could be attached to the landlord's own home, with fewer than 10 families sharing a toilet. $^{215}$

In most of the village locations, electricity was metered, though rolling blackouts occurred in summers, and days could pass without repairs. Flooding was less of an issue in urban villages than it was in other parts of the city. Water scarcity was the main problem, with most renters receiving 2-4 hours of piped water a day at a shared tap. A few participants in domestic service mentioned carrying jugs to their employer's household so that they could take water back home at the end of the day.

Jhuggies stood apart from the typical village street configuration. They were clearly built in lanes, gridded to maximize the number of units on stand-alone plots, some of which were enclosed. In several locations, Silokhera and Kanhai, for

\footnotetext{
${ }^{213}$ Households renting from these plots relied on open defecation in a nearby construction site, or vacant plotted areas.

${ }^{214}$ Can refer to more permanent, solidly built housing.

215 The Yadav family mentioned in a previous chapter rented flats to roughly 200-250 tenants per building, and no more than 3 persons to a one-room flat, although cursory observations showed that this figure was unlikely. This one family claimed roughly 10,000 tenants across not more than 2,000 units in Sikanderpur. Rent would be collected by visiting the flat in person. Electricity was paid at the end of a monthly period based on meters for each room. For up to 6,500 Rs a month one could get a flat with a separate toilet, with enclosed bathing facilities.
} 
example, colonies consisted of many lanes of one-story huts, enclosed by some rough fencing in an empty lot adjacent to a large multi-story stand-alone villa where the landlord's family lived. This created a sense of surveillance in the colony. Landlords could see in and observe garden-like rows of huts from their house, while the colony could not see its surveyors.

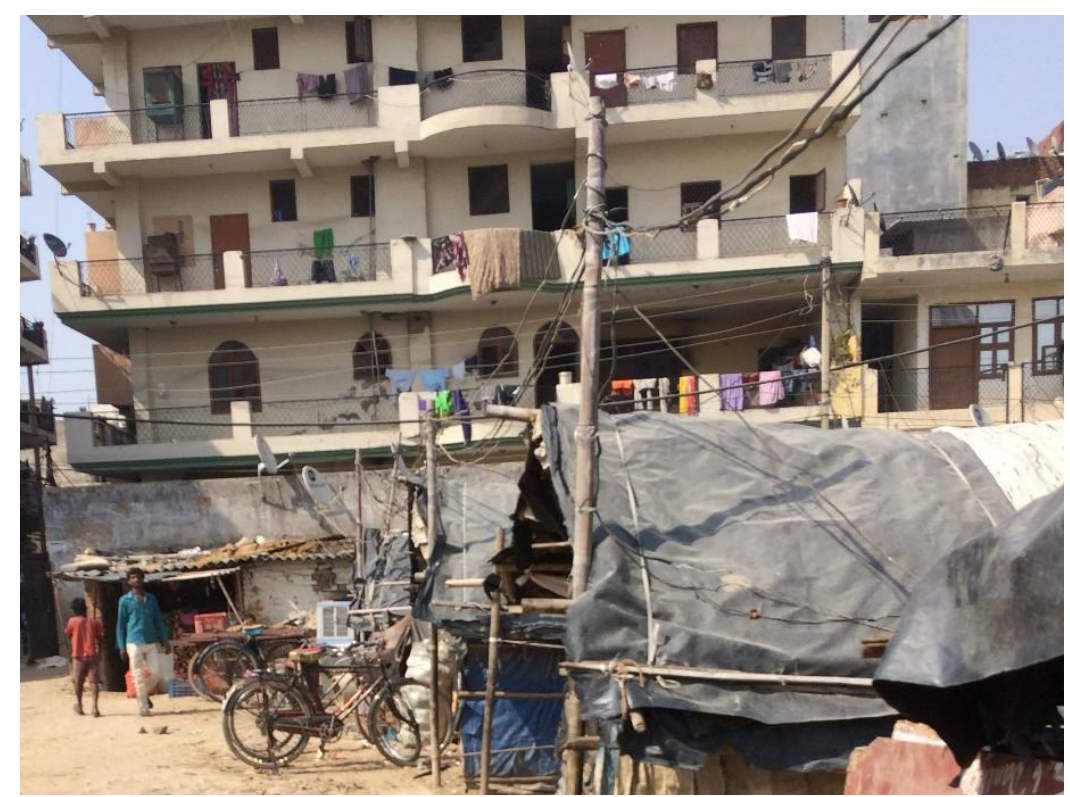

Figure 20: Pukka tenement housing in Chakkarpur Village. 


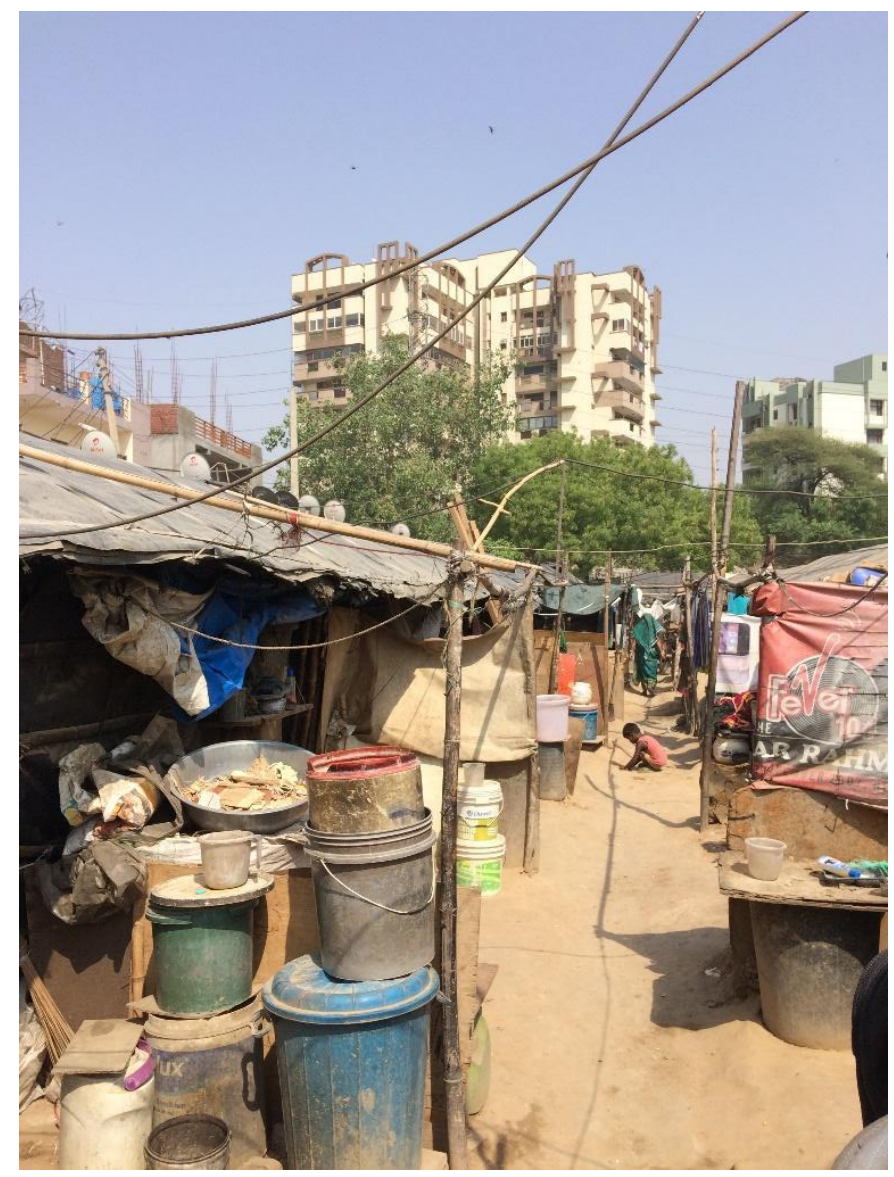

Figure 21: jhuggies inside Chakkarpur Village.

\section{The Paradigm of Migrant Assistance}

The beginning of this chapter described a day in the life of Sudhir, a Bihari migrant working in Gurgaon on the edge of Silokhera Village. His employer was also Bihari, a native of Patna, and a village outside the city in the previous generation. Chetan moved to Delhi for work, and eventually to Gurgaon for the private schools. In conversation, he hesitated to categorize his ancestral village. "Is it still a village?" 
Migrations within Bihar are transforming many of these small places into peri-urban towns. The village was a memory, not a place he could visit.

After 15 years of working on migration issues, including a collaboration with a friend at another NGO focusing on skills development for migrant workers in Gurgaon, Chetan founded his own NGO in 2009. The organization had completed close to 60 projects, from education, skills development, curriculum development, teacher training, and research. One of their studies included a survey with women from 6 villages to determine interest in training as cab drivers. Local women, from urban villages, were the most reluctant to take up such work, he found. "It was too risky."

As an NGO worker, Chetan had been a part of the logistics planning for several migrant organizations, setting up bases in both sending and receiving locations. When he began working on these issues, he said, "migration was more of a human rights issue than a development issue." The logic was, "We need to have facilities and amenities in rural areas to prevent migration." But experiences abroad, and in Sub-Saharan Africa, began to inform an approach to migration as an inevitability. Migration NGOs began to provide services at both sending and receiving locations and focus principally on the problem of identification.

Chetan had worked with dozens of NGOs, visiting villages in rural Rajasthan, where migrants were leaving for Gujarat to find seasonal work. Interventions involved providing migrants with a universal identity card, skills development, legal awareness, a call center, health care assistance, financial education and inclusion services. "Migration is centuries old in this country," Chetan explained. There are traditional 
migration patterns that have been established over years, but the general assumption now is that migration related urbanization will rise.

The nearby village of Silokhera, the target community for many of the NGO's programs, was populated predominantly by Bengali migrants. Language, Chetan observed, was an important source of social cohesion, that bound families who had no knowledge of each other before arriving in Gurgaon. The culture of home was a source of solidarity, even among households with no prior connections. "They recreate...the flavor of their home, around where they are, to the extent possible."

The migrants who sought assistance in Gurgaon had a voter ID card from their sending region. One of the difficulties of obtaining assistance or cooperation in sending regions is that local politicians do not want to lose their constituencies. ${ }^{216}$ Chetan observed exercising political rights is also, in some ways, a cultural practice. Among Bengalis, for example, casting a vote at home had a kind ritual element to it, while for other groups, political participation had less significance. "I think the firstgeneration migrant is so subsumed in just making a living that probably the thought of getting a local ID card would not occur," Chetan said. "they would not want to give up the voter ID card of the village...that also acts for them, as something which keeps them bound to back home."

For individuals migrating for work, the roots to the village were more palpable. It represented a social safety net where the city did not. For families, the quality of the

216 With each election there are stories of rural politicians currying favor with their constituents residing in urban areas. In the run up to the most recent elections, there were reports of direct cash transfers, gifts and transportation to bring migrants back to their rural districts to vote. 
jobs tended to improve in more structured or formal lines of work, even domestic service. With a secure job, households might loosen their grip on the village, and stay for longer periods of time, eventually giving up village voting rights. The difficulty of the work in construction and factories burns out working men before middle age, at which point they move back home. Chetan noted the physical toll, "I've met with migrants in villages who've suffered from accidents, had no choice but to come back."

The precariousness of the construction migration scene paired with the emerging trend of children in the auto-constructed construction worker camps had put this issue on Chetan's radar. "What kind of an education intervention do you design for them, it's going to be completely different...The ideal scenario would be to have like a portable identity card like the aadhaar card, something that sort of entitles a child to an education anywhere that he or she goes and which also that captures to what point has she studied or learned and it can be transferred." In working with different migrant communities in Gurgaon, Chetan found different relationships among migrants from different states. "I don't know why this is not the same with Biharis." Reflecting on his years of fieldwork in migrant assistance, Chetan speculated:

"Rajasthan is not very densely populated, so if you go to the villages of Rajasthan you do not get the same kind of community feeling as you get if you were in UP or Bengal, you know, where people are living together in more densely populated pockets...in Rajasthan things are more scattered. So, probably this could have a play."

Yet, the social cohesion or solidarity that seemed to exist among Bengalis or place-based professional development networks, has not led to political organization. Although no self-launched community organizations existed, recognition from NGOs 
had provided a kind of coherence to the populations as communities of place/kind. NGOs served the purpose of ameliorating temporary needs and making life easier for migrant groups in the meantime.

The previous chapters have addressed social organization and the channels through which urban villagers or middle-class activists and RWA members organize and influence the politics and planning of the city. As participants explained, and coordinating NGOs verified, migrants tended to rely on a strategy of "vertical patronage" and relationships rather than horizontal ones (De Wit \& Berner, 2009). Rather than looking to others in a similar position, migrants, such as Sudhir, formed networks through their employer in order to ask favors or assistance in times of need. In an environment in which migrants do not have access to state benefits locally, do not have the ear of a local politician, head man, or other person of authority, they may find a way through employers and NGOs that offer some of the services they are missing, including water, household goods, subsidized food, education, legal representation, and health care.

\section{Conclusion}

This chapter documented the migration strategies and living conditions for low-income migrants in Gurgaon. The issues raised by the temporary, yet long-term stay of households, particularly those from West Bengal and Bihar, presents a reality that challenges assumptions about urban aspirations among the working poor. While the research demonstrates strong aspirations in terms of education and employment 
advancement, these are not linked to a vision of city life or belonging within or to the city.

This chapter surveyed and described the conditions and materiality of migrant lives in Gurgaon's urban villages, a shared space between newcomers and local landowners. The challenges of material reproduction (the built environment), include poor and overcrowded housing, limited access to adequate water and sanitation or secure tenure. These resources depend on the nature of tenant/landlord relationships. Work, income, and household composition are pieces that fit together into a broader socio-demographic portrait for migration strategies in Gurgaon, that vary by sending region. While many participants had no knowledge of their neighbors, despite coming from a similar location, their shared experiences and choices seemed scripted before they arrived and settled alongside each other in the city.

By considering the responses of both tenants and landlords across urban villages, a sense of a housing and rental market for low-income migrants began to emerge in which it appeared that even contested lands and areas with insecure tenure, were tightly controlled or surveilled by local landlords (villagers), for whom rentcollecting was a primary source of income. As the Sikanderpur landlord in the previous chapter said, "buildings are my crops now." Even in cases of contestation on village peripheries, the battles over tenure at the time of the research, were occurring between local and state governments and former panchayats, not with new migrant communities. ${ }^{217}$ Migrant tenants were usually the passive casualties in the event of

${ }^{217}$ In 2015, a local councilwoman was beaten by police for filming a forced eviction and demolition of settlements on contested land. The occupants were former agriculturalists, not migrants. The laxing of land acquisition laws under the BJP government allowed the Regional 
forced evictions and were unlikely to organize or agitate. Without the ability to invest in land or own in Gurgaon, the city resists permanent resettlement by migrants from rural areas, whose families still own land in their sending states. These groups, while demonstrably poor, are pursuing multi-generational strategies for advancement. However, the rural village still has a powerful hold on adult migrants raising families in Gurgaon. Caught between their children and parents, these groups, seek to reunite them with an eventual return home. But this idealism is contingent upon the culture of the sending region. As the participants in this chapter have expressed, the city is not seen as a place in which to claim entitlements, per se, but as a tool or instrument for generating wealth. Whether Gurgaon presents an image that connects with migrant imaginaries of a future good life, as opposed to economic opportunity in the shortterm, remains to be seen.

Development Authority to go forward with the demolitions without the consent of the landowners. This incident was relatively high profile because of the council woman's social capital/status as an Independent, also one of the few middle-class, foreign educated (former Google employee) politicians in Gurgaon's Municipal Ward system. Eventually the Mayor, Vimal Yadav, threw out the charges against her. 


\section{CHAPTER 7: CONCLUSION}

"The universal and ineluctable consequence of this crusade to secure the city is the destruction of accessible public space."

-Mike Davis, City of Quartz

I arrived at the parking lot of Gurgaon's Aravalli Biodiversity park via cab around 4:30 am. Still dark, it took several spins around Guru Dronacharya metro stop, past the entrance of Sikanderpur Village, and the streets leading to DLF Phase III, asking a chowkidar at nearby Nilkanth hospital to find the correct entrance. The driver was concerned for my safety. "Ye jungle hai". It's wilderness. The area he gestured towards, fenced in with concertina wire, seemed arid or desert-like. There was enough ambient light from the highway to see the silhouettes of low trees and shrubs. The indigenous plants of Haryana are gnarled from a distance, nothing like the tidy hedges, lawns and flowerbeds in the gated colonies of the city. But the plants behind the wires were supposedly adapted to extreme heat and water scarcity. Some of them had already been described to me over the phone: the kulu or "ghost tree" has stinging nettles on its flowers; the Indian Screw Tree has red flowers that attract sunbirds; the sap of M. parvifolia can be used to treat jaundice, and Kali Siris has pale orange flowers and fixes nitrogen in the soil.

We pulled into a tidy pebbled lot. Before dawn the wilderness was already full of human activity: women in salwar kameez and jogging shoes speed-walking in pairs, followed by men in khakis and polo shirts, children, and joggers in full gear. The park was crisscrossed by a set of poured concrete pathways that blended into the rocky soil, with custom garbage receptacles along the way. I reassured the cab driver that 
everything was fine, and he could leave. He watched me apply bug spray, nodded and slowly pulled out of the gate.

I had come to meet the park's founders, who ran its development through an organization called "I am Gurgaon," founded in 2005, initially through corporate social responsibility seed funds. I met with a group of approximately 20 people, a range of ages, some volunteers, parents with their children, mostly dressed in hiking attire. We spent a few hours exploring the park with a botanist, eventually visiting the nursery and greenhouse where they grew the plantings from seed before transferring them to the park. We ended the tour with a light lunch and paper cups of nimbu pani in a small grassy picnic area near the parking lot, discussing the projects to come. Throughout the planting season they would bring school groups to help and given lectures about the biodiversity of the Aravalli hills. Students would be assigned to work with a volunteer chaperone and a gardener to plant the greenhouse saplings. They would help with the reforestation and raise awareness about the park. Win-win.

It was an exciting moment for the organization. The MCG was constantly threatening to take over what they had done. The park would have offered a perfect cover for corrupt bureaucrats looking to pocket government funds. They could have easily raised tenders for tree plantings and new gardeners and simply never hire them. They wouldn't know the first thing about what to plant, one of the members said. Meanwhile, the organizers marveled at how far they had come on their own. It used to be a denuded former mining pit, exploited for firewood, overgrazed, and now it was a real park. There were concerts at its outdoor amphitheater. People were coming from all over Delhi NCR to exercise there, bring their children, and learn about and value 
this ecosystem service. The terms flying around: natural, indigenous, park, wild, green space, were evocative and contradictory in some ways, but the conversation about the city and its possibilities was hopeful, and this park was contributing to that optimism.

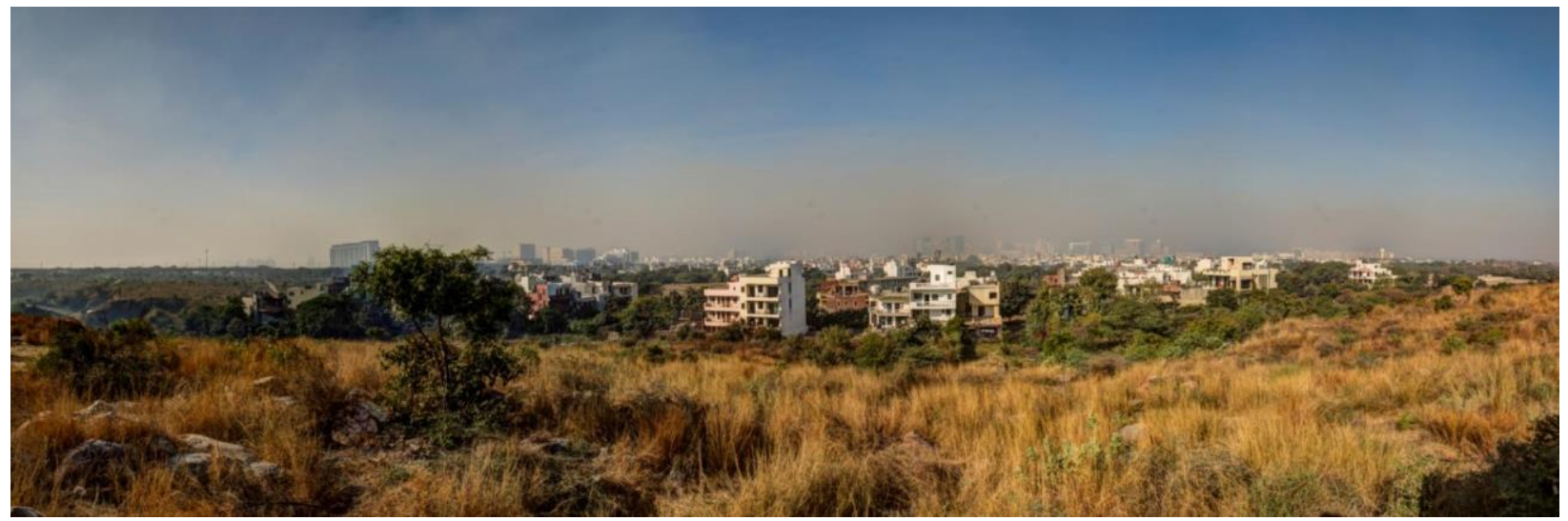

Figure 22: View of Gurgaon from the Aravalli Biodiversity Park.

A year later, I visited the park at $2 \mathrm{pm}$ on a Saturday, a trip with a friend and photographer to document the landscape on film. The gravel parking lot was empty this time, and there was no one in sight, except for malis and watering trucks making the rounds. We set up a tripod and took a series of panoramas, with the city in the distance and the park in the foreground (Figure 22).

After we finished our work and returned to the jeep, we discovered that we had been locked inside, and searched frantically for a guard who could let us out. When we found one, we were scolded for being in the park in the first place. It was no longer open to the public at all hours. Some deviants had been building fires inside, cutting wood and taking it. The park must now be gated to protect it from intruders.

In 2018, 500 informal structures, built by squatters, were demolished across 7 acres within the park as part of a massive raid on intruders. Apparently 400 police officers were summoned to oversee the demolition and protect planners ordering the 
evictions. Residents and business operators in DLF Phase III were concerned about the growing slum on the periphery of their neighborhood. A local business owner told the Time of India "Why should 500 hutments come up? People are just setting down where they find an inch of space. This problem should have been nipped in the bud earlier - but it's never too late, and I'm so glad that this is finally happening. Because you don't want the disease to spread to the point where amputation is required." The article went on to explain that once the land was cleared the Deputy Commissioner of the MCG had plans to green and beautify the 7 acres. "Action against the jhuggies may have been overdue but it was decisive and would have left the colonies residents hopefully feeling that much safer."

Only a few months after the demolitions and evictions, the National Highway Authority of India (NHAI) proposed cutting a new road from Delhi through the park, which would take over 100 acres (about a third of the total) with it. This immediately led to protest, as I Am Gurgaon's founders held rallies and signed petitions demanding state and local authorities intervene and stop the project. Through social and print media, the protesters argued that park was Gurgaon's “green lung”. Why would officials destroy something that offset Gurgaon's terrible air pollution in favor of an infrastructure that would surely exacerbate it? The plans of government actors hoping to win political points with real estate lobbyists in the next election, were temporarily tabled.

The battle over the park, and the "the green lung" of a city with a reputation for some of the worst air pollution in the country, seemed to braid together the various narratives of this dissertation. The park was the rehabilitation of a wasted landscape to 
its former indigenous plant life by the environmentally conscious middle-class, using corporate social responsibility seed money. Local government had facilitated this at a distance, but left stewardship in the hands of the elite, until it served state or private interests. The park was initially created for all, but was now gated off for some, by an organization called "I am Gurgaon," a name that asserted identity through place itself. The park was built to provide an ecosystem service, the "green lung," and a place for people to exercise, and for local species to nest or regenerate. But the scientific and ethical certainty of this project and its preservation has also involved mass evictions, state protests, corporate finance, government fraud, and a cohort of middle-class placemakers and urban squatters. Protesters belonged to the same corporate milieu as the developers eyeing the park's land and lobbying for government seizure and reclassification. How does one cast a value judgment in this situation or form a statement about the right course of action? How does one avoid casting a judgment? The park is aspirational to be sure: a statement about the ability of Gurgaon to provide its own ecosystem services and defy the image of an urban wasteland. It was also compassionate to the indigeneity of plant and animal life, emphasizing the importance of rehabilitating landscapes and protecting them from commercial development, but ignored some of the long-standing needs and uses to which indigenous forests and wilderness have served human beings. The park is a pristine showcase and source of recreation or enjoyment of nature within the city, perhaps it cleaned the air too, but it also informally began to provide food, fuel and housing for the city's urban poor. Where was their alternative? And why wasn't meeting those needs recognized as part of a lasting vision or practice of urban sustainability? 
I describe this final vignette, of the citizen-run NGO that anthropomorphized urban nature and the city as self, to braid together the strands of what I have argued throughout this dissertation: that place and identity are deeply relational, and that planning (whether public or private), still has a powerful role to play in supporting these relationships or harming them, and by extension, the public. The possibilities for planning have not been foreclosed, but Roy's (2009) explanatory argument for why India cannot plan its cities persists. This argument rests on the ways in which planning is practiced in India (as a type of management rather than future proofing) and thwarted, by the politics of insurgency or protest, which do not always support a more just city. Reframed through the language of attachment, Roy's (2009) informality might be understood as a quality or characteristic of interaction that shapes the nature of place and the security individuals and communities feel in relation to it. As local governments build capacity or outsource it to the private sector and citizen-run NGOs, they may already lack important knowledge of the territories they govern. While the decision to keep land zoned in particular ways can work to map them or make urban space visible, such as the Aravalli Biodiversity Park, these processes can also work to “unmap" urban places, such as Gurgaon's village abadis. However, unmapping implies an antecedent process of mapping, or technocratic involvement, that may never have existed. The formalization of the village tenure would require imposing a system of order that did not previously exist. As the DC's Assistant informed me during an interview, the MCG did not have surveys or deeds of ownership for the village abadis. To go in and collect or impose that kind of boundary information now would cause political unrest, and hence the process was avoided. The danger posed by 
informality in such cases to their publics is the maintenance of ignorance and absenteeism, in which the state manages its shortcomings or unwillingness to get involved in a political fight through calibrated mea culpas i.e. "we lack capacity". "What then is planning?" Roy asks. "Is it that which remains bounded by the law and upholds formal regulations? Or is it the relationship between the published plan and unmapped territory? In India, it seems to be the latter" (p. 81). If the argument is that public planning is a false front for private interest, now fully realized in a publicprivate partnership model, what is to be done? The space between the formal and informal, where formality belies another world of informal operations and motivations, is the central trope of corrupt bureaucratic government, and a justified one in the case of Gurgaon's urban planning history. To overcome such tropes requires a different way of thinking about them in relation to the work of "good" planning. Roy (2009) points out that a kind of "good" informality is part of planning theories of communicative practice championed by Innes, Connick and Booher (2007) a 'a valuable strategy of planning'. But informality here is not spontaneous interaction or informal relationships, but highly calculated, as Roy (2009) points out, and reinforces the structural boundaries of power and state governance rather than blurring them. If the assumption is that informality and insurgence are the enemies of sound urban development, then indeed, India may never be able to plan its cities well, but if informality can imply relationships that subvert monopoly corruption in state governments, and insurgence can include insurgence within and between government institutions working to protect their publics, then perhaps some planning, and some 
failure to plan, in the case of the highway through the park, can become successes in disguise.

My argument here has not been about informality per se, but rather about the affective ties between planners and the public, the publics and territory itself. The idiom of urbanization may be bad for city planning, broadly conceived, but why is informality at a systemic level necessarily harmful? What does this idiom do to people or the ways in which people think about themselves, their benefactors, their membership in a polity, and their control over their own environments or destinies? In some ways the irrationality of this style of planning stirs conflict precisely because it enables the kind of displacement and uncertainty that vexes attachments to place and the role they serve in providing continuity and freedom in everyday life. Any urban planning or urban development regime that is unpredictable, inconsistent, and unavailable to those it plans for, becomes a source of dread and apprehension rather than an agent of hope and guidance. When that system of meaning and guardianship presented by planning or state governance is radically altered from election to election or does not seem to operate in the light of day, or has preferred routes of access with the elite, those who believe in these institutions may live in a state of hypervigilance. The residents of DLF Phase III, who praised the MCG for demolishing squatter settlements in the biodiversity park felt unsafe before the municipality came to their aid. Risk and the perception of risk were occluded in many of the activities and acts of insurgence and placemaking presented throughout the dissertation. Participants were often primed to see those in proximity as intruders rather than neighbors, and to look suspiciously at all institutions, but also find ways to emulate them or play by their 
rules. When the state sets a standard of inconsistency and encroachment, it is not surprising that its subjects expect this of one another as well and may even adopt similar strategies. The rest of this chapter asks how one operationalizes this lens or brings these stories and the social construction and attachment to place into a praxis of planning.

\section{A Digression: Development and Planning Dilemmas in the Global South}

The starting point in this dissertation was a set of conversations about planning and development regarding the 'bad city' of the Global South. Such places may be doing well in economic terms, but wealth alone has not produced livability. Such places still face profound challenges to the provision of basic infrastructure, goods and services, housing, and crises of environmental governance and social justice. As scholars grapple with the implications of the real-estate turn in the Global South, and the kind of splintering urbanism that emerges from it, there are a few directions one can go. While a developmental approach to Global South urbanism emphasizes the delivery of essential services to the urban poor, i.e. water, access to sanitation, medical care, nutrition, education and durable housing in slums and informal settlements, within these conversations is conflict over what sorts of conditions constitute material problems, vs. normative assertions about bodily and spatial practices within diverse cultures and contexts. Postcolonial readings of urban public space, for example, make addressing something as simple as a toilet in India, a complex conversation about the politics of shit, where class conflicts over public space, and over the ways in which who shits where and who cleans are part of and reproduce long-standing social 
hierarchies. It becomes a paralyzing task to work in this mode of problematizing and theorizing the urban without a way forward. If one adopts an empiricist approach, it is also easy to misread complex systems, and risk harming the intended beneficiaries of development. The epistemological resolution for this in development discourse has been, to some degree, the adoption of a capabilities approach. The ethical bind of doing development is resolved when change comes from within, or when a system or theory of justice is generated or sought by "participant observers" (Benhabib, 1995). This framework theoretically allows the urban poor to tell their own stories, or to bootstrap their own development, and seek universals (i.e. toilets) on their own terms. This framework came to prominence in the 1990s, just as India opened its doors to foreign direct investment and economic liberalization and the results of structural adjustment programs were beginning to roll in. Emerging economies, such as India and China, were beginning to make visible strides on macroeconomic terms, lifting hundreds of millions out of poverty through the engines and distribution of capitalism and global flows, also producing or exaggerating urban inequalities, and fueling displacements or mass evictions under the logic of real estate development as economic development (a net good). Urban planning supported this and worked to combat the image of Slumdog cities through economic and urban development, hiding or erasing traces of third world urbanism in favor of projects that promoted and outsourced development of new towns, the middle-class suburb or the global city to private builders.

The initial puzzle of generating a planning theory or way of seeing from the South is, to some extent, about how one epistemologically balances the imperatives of 
development with those of urban planning, while recognizing the issues raised in postcolonial discourse, i.e. the history and traumas of colonial rule and its planning governmentalities, meanwhile neoliberalism often disguised in the discourse of selfhelp, continues these traditions of erasure and social injustice. There are very practical reasons for a planning theory generated in situ, as Watson (2009) explains, not limited to the mismatch in assumptions about the corruption of state officials, the blurred boundaries between formal and informal sectors, deep poverty, cultural complexity and so on. Whether or not the Global North has applicable lessons to impart to the South, however, the very relationship of vertical patronage in that transfer is problematic.

Nonetheless, the professional world of planning in India has not changed. Planning practice in India evolved out of a historical reality of exchange and acceptance or adoption of European and North American planning norms (circa the mid-20th century). Colonialism, globalization, and late stage capitalism have muddied the waters of place as cultural context, the latter through mechanisms that cater to personal choice, aspiration and individual expression.

In this context, the older binaries of encounter, between the West and the rest, between modern and traditional, urban and rural, wealth and poverty etc. are confused. The city is confused as well. Gurgaon came up during these macroscale transformations, and coalesced as an urban center, mixing and blurring the dualisms of capital, or the antinomies of global city making, materially and symbolically. The city had generated a reputation for the ugliness of middle-class commercialization and sprawl, i.e. shopping malls and gated communities, without the centers of traditional 
urban placemaking, parks, public squares and civic buildings. It was also a place that, in its hyper commoditization of space, had marginalized its ancestral inhabitants and the migrants who had built it and helped it function. No one in the "bad city dream" is entirely satisfied with the way things are going, even while many also believe that the city is a place worth caring about. Meanwhile, there is no evidence of this discomfort or ambivalence in the marketing and real estate rhetoric among private builders and public planners, who seem to be engaged in a closed-circuit conversation about what the city is, without consulting its publics.

When I first began to study Gurgaon, I wanted to problematize the city's trajectory along the lines Srivastava's (2015) “entangled urbanism.” The relational reading of slums and gated communities seemed to bring something to the discussion that was missing in an ostensibly splintered urban form. Drawing out this image of entanglement to its logical conclusion however, I have argued that the coproduction of wealth and poverty in the city's enclaved spaces, also makes it difficult to consider the challenges of material reproduction for the urban poor without looking at urban affluence. It is difficult to look at issues of placelessness, fear and anxiety among the middle-class residents of gated colonies and public space, without looking at the perceived source of that fear. To frame this kind of entangled urbanism or define it along the lines of the first and third world hybridization of placelessness and nonlivability is not the end goal of the dissertation. It is just the starting point. The bad city dream is a conflict that I wish to deconstruct. The bad city is not dialectic or dialogic. Clashes of ideology, of class, or rural vs. urban work on the level of heuristic theorizing, but do not necessarily offer common ground. 
The dissertation told a planning history of the city through the lens of the construction of place and its maintenance, of placemaking. By focusing methodologically on the ongoing social construction of place through participant observers, a set of material or aesthetic problems emerged as identified by participants themselves. The previous chapters have demonstrated the ways in which place is socially constructed in Gurgaon, and how place(s) are constitutive of individual and collective identities and their attachments. I have argued for the need to think of place as more than the public square or the public realm, or the "small, inhabited and cherished" unit that Friedmann (2010) and others have focused on in hypercommercialized cities of the Global South. The arguments of sociologists and planners who came to work on community development in Delhi during another period of tremendous social change and urbanization, the post-partition era, focused on creating social cohesion among new urbanites and refugees through apolitical societies and the built environment. The emphasis on public space, walkability and community activities, was part of a democratic project, using "social science operations," to trigger placemaking, without addressing broader systemic challenges of the built environment, urban governance, social justice, poverty and inequality, and the ways in which material and symbolic reproduction overlap through place. As I argued in Chapter 2, placemaking is not just a residential practice, or a practice of small spaces. It engages the broader narrative sweep of nationhood, of cultural identity, difference, and issues of globalization, economic development and environmental catastrophe. Placemaking and the social construction of place feed on and adapt place narratives 
that reconstruct the past, and make sense of where one's community, class, gender and so on fit into the context of its story or the social order of an urban environment.

As described in Chapters 4-6, conceptions of place encompass and link various scales of symbolic and material reproduction, between the home, the neighborhood, the civic realm, individual residential histories, communities and an idea of the city and environment more broadly. It involves the already existing relationships that newcomers and locals must have with actually existing places, memories of places past, remote, or imagined. These notions of place are expansive and draw from memories and imaginaries of rural villages in West Bengal, mythologized ideal villages founded by characters in religious and epic texts, Florida Golf Courses; from East and South East Asian model and mega-cities, to the ideal neighborhood unit in New York and Chicago or the colonies of South Delhi.

How these diverse imaginaries, aspirations, and understandings intersect through territorial practices and claims to the city, reflects individual and collective/communal notions and attachments to place. These attachments, at times solipsistic, are more than the cherishing of space, but dynamic relationships. Through various kinds of activities and actions individuals and communities perform, nurture, maintain, or protect this relationship. To assume the meaning produced by this relationship as maladaptive or a kind of projection of a fantasy life when it discords with certain principles of design is to discount the ability of placemakers to see themselves in relation to their environments and the significance of imagination, of myth, fantasy, and dreams and play in the construction of place. 
It is difficult to generalize an urban aesthetic of placelessness that is not historically contingent or predicated on normative values. When a participant in the Preface to this dissertation stated that Gurgaon lacked a cultural umbilical cord, he was making a statement that was both true and untrue. It was easy to parse what he meant: that Gurgaon didn't offer something that connected to his own sense of place, and therefore he could not connect to it.

There is a certain risk to romanticizing the act of placemaking. While the stories here highlight the extent to which it can be an activity or a practice of working through loss and change, it can also be maladaptive and lead to conflict, or become a design concept that caters only to a certain set of elite homeowners. But more importantly, there is a risk, in over championing placemaking, of allowing planners to fade into the background and for professional practice to become irrelevant or to live up to the worst criticisms of India's urbanization idiom. It's easy to declare planning's failures, particularly in a place where the problems of informality, corruption and weak state governance, combined with the power of everyday insurgence, make planning seem impossible. My argument here has not been to condemn the profession of planning in India, or to suggest that planning is unnecessary in the face of citizen resilience and capacity for self-governance. My argument, rather, has been that planning is needed, even when it seems impossible that it will ever change. There has been an ontological mismatch between what planning does or how it conceptualizes its role in serving the public, and what planning for such a space or moment demands. What then do we learn from thinking about the salience of place and the art of placemaking in Indian cities, and the Global South more broadly, as planners? 
As Chapter 2 argued, Gurgaon's Millennium city narrative relies on various roles, a cast of characters, to function as a heroic one. The victim and sometimes antagonist in this story are the arid landscape that preceded the city, underproductive and populated by disparate village communities. The government too and its "labyrinth of archaic laws...all levels of bureaucracy and policy makers with outmoded mindsets" is an antagonist in this story, but the resulting story bears a fun-house mirror resemblance to a place that people actually know "an international hub of business...a city offering some of the best housing in India.... pacesetter for urban development in the rest of the country." Doreen Massey (1997) wrote that place narratives can create meaning but also produce conflict. I have argued that the narrative of resource scarcity and backwardness, and the promise of modernization has been unhelpful in building a vision of place for both the local populations, who have had to renegotiate a kind of urban identity, while confronted with cultural divisions between different middleclasses. A response to this unhappiness, from the position of power risks pandering to or mythologizing indigeneity or offering moves that do little to resolve and even exacerbates tensions between groups, such as the renaming of the city to Gurugram. It has been more of an administrative ordeal than a substantive revisioning for the city. Such nods to the local only mildly appease or engage such publics at best and use them as a pretext for other political expediencies, at worst. Acknowledging the public through naming or story telling alone, does not foster substantive change or reconfigure the nature of conflictual relationships. As Cobb (2013) writes, in public meetings and attempts to bring disparate groups together to achieve resolution further fragmentation can occur. "Fragmentation, in the context of problem-solving, refers to 
the way that problem-definitions are all too often broken down into parts, yet they exist in a system that defies the summation of the parts. Fragmentation also refers to the way that social networks impacted by the problem are also cut off from each other ideologically."

To contextualize this in a setting such as Gurgaon, where fragmentation occurs across multiple realms, spatially, infrastructurally, and in terms of governance, these fractures of identity obscure the relationships and needs, and common interests shared by groups who believe they are fundamentally at odds in a zero-sum game. Even convening or bringing together disparate groups "can fail miserably when they cement, rather than evolve, the way the community makes sense of its problems." There is a real need for braided narratives and new ways of telling a story that acknowledge experiences of dispossession, and the dualisms of adaptation and resistance. But to evolve a new kind of narrative of place, one that is deliberative, requires a sustained engagement with place and its publics. This is a task that planning, as an institution, and administrative practice, as demonstrated in Chapter 3, is not yet prepared to take on, or designed to address. This type of community development has typically fallen to NGOs. While the most dominant civil society players in Gurgaon are property-based common interest developments, the kind of narrative braiding or coalition building that would help define such a vision, requires the breakdown of these divisions between groups. The boundaries may already be blurring.

The stories here have also highlighted the power of social organizations engaged in environmental activism and placemaking, and the importance of 
recognizing what they get right, where they go astray. Depictions of class phenomena that only focus on the latter may lead to a dead-end pathway, emphasizing the problems with consumption and class norms without acknowledging the potential cracks in those narratives, and the ways in which individuals can recognize their own positionality and learn from it.

While the actors portrayed here have all asserted their claims and rights to place in the city, or someplace beyond the city, in the case of low-income migrants, and many have acted on this through various types of organization, activism, government involvement, media and their power as consumer citizens or voters, the common call among all these voices was for security and autonomy, and ultimately strong local government. Decentralization was the desired outcome for most across the socioeconomic spectrum and within class divisions. Decentralization was also desired by small developers as well, who believed business innovation would be easier with local autonomous government. While most of the participants here desired the ability to self-govern and to have autonomy over their environments, it was universally acknowledged, among Urban Villagers, RWAs and activists that their work and striving could not carry on indefinitely but required the broader platform and support of a democratic government. Rather than dismiss the potentiality of the state, or embrace it, participants continue to hold it to task. Before any process of reimaging or envisioning more circumspect or integrative narratives and storytelling can take place, the processes and institutions that support local decision making will need to evolve. And while not openly acknowledged but government actors, the process of building or retroactively planning a city requires reckoning with who the city's citizens are. For 
newcomers, migrants and locals, the complex process of imagining, striving and making do is not the succumbing to a con of fictional urbanism, or the place that was promised, but is really the beginning of the process. For the participants interviewed here who belong to the majority low-income migrant population of Gurgaon, a cohort who essentially built the city, the slum is not home in the city or the endgame, but a means to some other future, just not yet. 


\section{APPENDIX A: METHODS}

\section{Archive}

The chapter on the historical development of Gurgaon draws primarily on archival materials. These included Gazettes, reports, laws, court cases and formal investigations. I draw from a detailed formal inquiry conducted in the 1970s in Delhi courts to describe the events leading up to Gurgaon's first major industrial land use conversion, the Maruti deal and the Chief Minister's dealings with various actors, including K.P. Singh. The Chapter also draws from K.P. Singh's well-known autobiography, which I take as an authentic account of Singh's motivations, memory of events etc., as he wishes them to be understood in the public domain. His accounts are treated as representational, rather than concrete evidence. Supposed statements of fact are annotated or fact-checked, for example Singh's references to land use laws for the State of Haryana, Delhi and the National Capital Territory were examined in concert with known repeals, amendments and challenges over the past 40 years, which correspond to events, such as lobbying efforts, described by Singh and others. All source texts were considered alongside other published materials and accounts by scholars who have conducted archival work on overlapping periods, for example Emma Tarlo's (2003) accounts of the Emergency Period in Delhi, in which Haryana actors named in this dissertation played a central role. 


\section{Structured and Semi-Structured Interviews}

Approximately 200 subjects participated in the research through in-depth and brief interviews. The methods of recruitment involved snowball sampling, as well as email, phone calls and in-person invitations. As the poster child for India's economic liberalization, Gurgaon had become a critique neoliberal urban policy, but much of the criticism I observed came among what Benhabib (1995) might call participants who "assume the attitude of observer vis a vis their own value system" (p. 241). I wanted to understand this self-critique on its own terms, hence the focus on interviews, observation, and participation in social organizations and group activities and social events.

Beginning in Chapter 3, I incorporate structured and semi-structured interviews and participant observation drawing from roughly 80 participants. Chapter 3 draws from observations beginning in 2015 through late 2016, involving observation of planning bureaucracy, attendance at events, such as the affordable housing draw, a visit to Chandigarh, and several offices across the city. This chapter is also informed by over a dozen interviews with planning professionals. Only a handful of these were recorded using an audio device, and most participants expressed the wish not to be named or quoted directly, except for Satyaprakash, the District Commissioner of Gurgaon, during the time of research.

Most participants in Chapter 4 were residents of either DLF or Unitech housing colonies. This cohort included not only residents of gated colonies, specifically, but also agents who worked for the developers responsible for building 
and maintaining those colonies. The participants in this portion of the research often, but not always, wore several hats as residents but also activists, or professionals. I interviewed at least two heads of large collegiate structured RWAs, including the head of DLF's 8,000-member RWA and Nirvana Country (a Unitech development), which had 1,200 households and 118 representatives in its collegiate structure (one representative per ten households). I interviewed residents of these colonies who also worked as professional planners, architects, or community organizers, ran NGOs or even served on multiple NGOs while running a private business. Friedmann (2010) acknowledges the nature of this caring as place attachment that, while described or explored through story-telling, is most visible through action. "The number and variety of local organizations that depend primarily on local volunteering can perhaps provide an additional if indirect, measure of place attachment."

These actors often had an overarching or "big picture" grasp of Gurgaon and could speak in professional dialects or idiolects that were commensurable with planning, though I began to modify my own terminology in these conversations. With this group, I did not need to worry about implanting terms or concepts that were not already there, however, I was aware of or at least sensitive to my positionality as an American woman and a student representing an Ivy league university, as well as a certain area of expertise. This granted me some access, a degree of legitimacy, and a certain kind of social status initially.

Some of the participants were academics or frequently published articles in local and national print media. I read and referenced their articles and professional reports where relevant, or where some information they provided in an interview could 
be accessed in a more developed (or peer reviewed) form. I interviewed servants or domestic workers who lived in some of these households, as well as a handful of households who merely rented within these colonies and had no formal involvement with RWAs.

A standardized set of questions was used, often on an initial phone call to determine whether a longer interview would be helpful or possible. Participants would almost always answer cold-calls, even if they didn't recognize my number. Emails were also used to recruit where possible. Interviews would either take place in the participant's home, a clubhouse or restaurant associated with their colony, or in a third neutral location, such as a coffee shop. Only rarely did I meet a participant at their place of work, but these participants tended to be in design professions and the use of their office would enable discussion of professional materials and include or make introductions with other employees in the office.

The nature of the research questions and the iterative process of refining them meant that data saturation was an inevitability to some degree. However, even when information was repeated, participants usually provided either a way to verify a critical piece of information or test the validity of other interviews. Interviews could often become generative discussions that engaged and developed mutual thinking about the issues at hand. The pushing forward of ideas and framings or theorizing along with a participant was a kind of work that proved helpful in the final analysis and coding.

Middle-class participants were often well networked, and willing to help recruit other actors who could answer additional questions. Finding the extent and connectivity of these actors, and how frequently a participant might have a common 
connection or know of other individuals in the study was revealing and helped map a kind of social network. My initial thinking about gated colonies, for example, was that they might be insular neighborhood units. But as I found myself visiting apartments and townhouses in dispersed corners of the city, based on snowball sampling, I found that connectivity and proximity were not always correlated. As part of my participant observation with this group, I adopted communication tools and strategies that were common within these networks, joining WhatsApp groups, online listservs and forums. I began to follow Gurgaon's traffic police and other pages on Facebook where important announcements were made. I attended events sponsored by organizations founded and frequented by participants. Most of the interviews conducted with this cohort were in English. They were recorded and transcribed. In coding and conducting discourse analysis of interview transcripts, I accessed not only the ideas or meaning contained in the words, sentences and paragraphs, but also considered the feeling of the room in which the interview was taking place, aspects of speech, behavior, the tenor of voice, engagement or indifference to certain topics, or distractibility. In focusing on language, I looked for initial themes, recurrent arguments, as well as information that I would fact-check and verify in interviews with public officials or other "experts". I also used coding software (NVivo) on initial transcriptions to identify nodes and compare clusters of interviews with others. Despite shared complex knowledge of the field, private practitioners in planning related fields were often more willing to take a theoretical lens or speak candidly about topics than government officials. Interviews often required follow ups, or further fact-checking. Though my 
consent protocols were standardized, one script or set of questions for every interview was not feasible or reasonable across the range of participants I encountered.

\section{Participant Observation}

The research draws on observations of behavior in interviews, as well as during visits to field sites, in public meetings and events hosted by various institutions, companies and professionals. The descriptions of those settings include professional, commercial or residential and community spaces in Gurgaon. Documentation included field notes, memos, details that emerged in recordings, maps and photography. During interviews in urban villages with low-income migrants, notes were taken on the housing conditions along with brief descriptions of housing and exterior spaces, detailing the lane, the range of activity there, the various amenities, the types and quality of building materials, means of construction, presence of electricity, fans or aerators, TVs, mementos and other objects in the home. Such objects often told stories about the relative conditions of wealth within a household as part of a cohort and could serve to differentiate minute details about quality of life. For example, in one household a ceiling fan appeared to have been taped back together. When asked, the participant mentioned that it had recently collapsed and injured her son, gesturing to a child with a bandage covering sutures on his head. The cost of the medical care was a major concern for the participant, and she was now afraid to run the fan at night despite the heat and the fact that it kept dengue carrying mosquitoes off their legs. Not all such observations are documented in the dissertation itself, but the experience of them had a cumulative effect during interviews of establishing a sense of a material reality. They also portray the degree to which it is easy to over or underestimate the 
value of possessing certain goods, which might typically serve as proxies for wealth. These objects can range in terms of quality, are often bestowed or are adopted second hand from employers, and occasionally bring new burdens and costs in terms of safety and maintenance. As many of these participants were living under informal tenure arrangements, I keep such details anonymous at their request. While I include images of various colonies and the villages, including exteriors of homes, interiors were rarely taken inside slums by the request of participants.

\section{Survey}

The primary approach to data collection was interview, the shortest of which were 20 minutes. During interviews with approximately 120 low income migrant households (approx. 480 members) across Chakkarpur, Sikanderpur, Kanhai Ganj and Silokhera villages, household data was also gathered using a simple survey instrument (see Appendix B). Information gathered included the number of members in a household, incomes, education attainment, languages spoken, whether households had formal tenancy agreements, voter registration etc. This information was anonymized and compiled in a simple database for future reference. Interviews were conducted in Hindi and Bengali. Due to issues of literacy, oral consent was obtained using information sheets in Bengali and Hindi read aloud. Due to the safety risks of going door to door, participants were recruited through social networks and snowball sampling methods. 


\section{$\underline{\text { V. Mapping }}$}

The research involved some GIS and mapping techniques. Data sources included Indian census boundary shapefiles, road files and population data produced by the Indian government as well as historical boundaries from the 1950s onward for the states of Punjab and Haryana. Sources also included Google Earth and open source, crowd-sourced sites such as Wikimapia's API and Open Street Map, which were useful in establishing boundaries of residential colonies and villages and could often be more accurate than Google Earth or municipal records.

Georeferenced satellite imagery during over a fifteen-year period was useful to look at the changing footprint and water bodies of urban villages and gated colonies before and after municipal incorporation. Similar maps depicted the location of other sites such as the original Maruti plant. Additional maps included georeferenced plans using a base map, as well as geocoded addresses of municipal ward councilors, and flow maps of internal migration trends. 


\section{APPENDIX B: INTERVIEW PROTOCOLS AND SAMPLE QUESTIONS}

Sample Interview Protocol (English)

\section{Questionnaire/Interview Protocol}

The questions are suggested for guidance, as the interviews may often be open ended conversations or semi-structured.

- Introduce the project

- Explain confidentiality measures

- Request permission that the interview be recorded

- Provide consent documents for their approval

\section{Sample Introduction:}

Thank you for agreeing to take part in this research. I am a PhD student at Cornell University in City and Regional Planning. I am conducting a study about how residents of Gurgaon experience the city as a place in which to live and work. Information from this study may benefit community residents, governments, and scholarship in the future by altering the way we think about planning in Gurgaon and similar cities. Please answer these questions honestly from your point of view. I am not being paid or employed by any other participants in this study. Your responses will be anonymously collected and analyzed with others in order to derive lessons for future planning practice.

\section{Sample Interview Questions Regarding Residential History:}

1. How long have you lived here? Who lives with you? Ask for more details or description of household/family members. Do they have staff or help in the household and do those people live with them?

2. Do you rent or own your home? Do you have any tenants? Landlords? What is your relationship like?

3. For new homeowners: probe for how long they waited before they moved in after purchasing or how long construction took if a new property.

4. Do you live only in this location, or do you have other homes? If so, how much time do you spend here?

5. Where did you live before moving here? Where did you grow up? How does it compare to where you live now? Why did you move? 
6. What did you like or dislike about where you grew up? Your current residence?

7. Do you visit your staff's homes or know where they live (if outside the home)? How do they come to work if they live outside?

8. Do you know the developers? Can or do you communicate with them regularly? What is the typical interaction like?

9. Are there any local community groups or organizations in your neighborhood? Do you participate in them?

10. Probe about profession or source of income and past professional training/education.

11. Describe a typical day in the city. A special occasion?

12. How do you travel in the city? Do you have a car, a driver, or use public transportation etc.?

13. Where are your most frequent journeys outside your home? Where do you like to go for entertainment? Shopping?

14. If there is a problem or concern about your neighborhood, street, home or other aspects of city life do you usually do something about it?

15. Where or to whom would you address such problems? When would you decide to solve them, and how would you go about it? Any stories or anecdotes?

16. Do you have friends or family in the city who do not live in your residential community/village/gated compound? Ask for elaboration.

17. Can you describe your house, or the appearance of your neighborhood?

18. How long did you plan to live here? Did you look at other homes? Cities? What made you decide to move here? Stay here?

19. What is your view of urban planning? What do you know about urban planning in Gurgaon?

20. What kinds of amenities do you have access to? Is there anything you would like to improve or keep as is?

21. From your perspective, how do local government, community organizations, private developers, respond to problems that arise in your city or neighborhood?

22. Who do you interact with in your neighbors? Do you see a lot of interaction between different households, neighborhoods or organizations? 
23. What was your role in the local RWA, housing society if any? Are they active in your compound/village/neighborhood?

24. Would you leave for any reason? Why? What would you look for in a new home?

25. What kinds of questions are left unanswered when you moved into your home?

26. Is there anything else that you think that I should know to understand life in your neighborhood, in Gurgaon?

27. Can you show me around your home/street?

28. Do you ever visit or know people in [name local village or gated community]?

\section{Sample questions for Staff/Employees of Homeowners in Gated Communities}

The above residential history questions are general and will be tailored to the participant. These will be used for residents of villages and domestic staff who work in gated compounds, and do not rent or own.

1. How long have you worked for $x$ ? Try to ascertain what kinds of work they have done in the past if this is not their first position, and details about their duties or daily obligations and life as an employee in the household, as well as level of education.

2. Do you work for multiple households in this neighborhood or in the city?

3. Do you live with your employer? Where does your family come from? Are they with you or elsewhere? If immediate family does not reside with them probe about why that is, if they plan to bring them to the city, or return to their home village/town/city.

4. If they do not live with their employer: where do you live in the city?

5. How do you commute to work? How long does it take?

\section{Sample Interview Questions for Planning Professionals}

1. How would you describe your professional role/community? How did you begin your professional path and what brought you to live or work here? Probe for specifics about their work, duties, responsibilities, current projects of relevance.

2. How would you describe Gurgaon? What makes it similar or different to other places you have worked or lived?

3. Are you familiar with housing development projects in Gurgaon? Do you know if or how such projects affect the villages and communities who were 
there before? Who are the important actors involved? Probe for specific anecdotes or stories.

4. What do you like or dislike about Gurgaon? What would you change or want to stay the same?

5. Could you please reflect upon the role of planners in the area from your point of view?

6. What is your knowledge of resident groups? Public planning's involvement in the city? Are there plans or projects for the future underway that I should know about?

7. What challenges did you face or witness with respect to relocating to or working in Gurgaon?

8. What kinds of questions are left unanswered after your experiences with Gurgaon?

9. Is there anything else that you think that I should know to understand life in Gurgaon?

Ask them if they have any questions or additional comments. Thank them for their time.

\section{Additional Interview Questions}

1. What is your name? Age? Married?

2. Where are you from originally?

3. What is their school/education background/training? Language skills etc.

4. How or why did you come to live in Gurgaon?

5. If it's for work, what do you do for work? Do you have more than one job? What did you do before?

6. How did you find the job/housing?

7. Do you rent? What is the rental situation like?

8. Do you live only in this location, or do you have ties to family, go home? If so, how much time do you spend here?

9. Where did you grow up? How does it compare to where you live now? Where did you live before moving here? Why did you move? 
10. What do you like about where you live? Either the building, the block, the neighborhood? What do you dislike about these things?

11. Do you have friends in the area? Who do you interact with?

12. Are there any local community groups or organizations in your neighborhood? Do you participate in them?

13. Describe a typical day in the city. A special occasion?

14. How do you travel in the city? Do you have a car, a driver, or use public transportation etc.?

15. Where are your most frequent journeys outside your home? Where do you like to go for entertainment? Shopping?

16. If there is a problem or concern about your neighborhood, street, home or other aspects of city life do you usually do something about it?

17. How long did you plan to live here?

18. What kinds of amenities do you have access to? Is there anything you would like to improve or keep as is?

19. Who do you interact with in your neighbors? Do you see a lot of interaction between different households, neighborhoods or organizations?

20. Is there anything else that you think that I should know to understand life in your neighborhood, in Gurgaon?

\section{Urban Village Household Survey Instrument/Questionnaire}

\begin{tabular}{|c|l|l|l|l|}
\hline \multicolumn{2}{|c|}{ Questionnaire } \\
\hline $\begin{array}{c}\text { Sl. } \\
\text { No. }\end{array}$ & \multicolumn{1}{|c|}{ Questions } & \multicolumn{2}{l|}{ Write your responses here } \\
\hline $\mathbf{1}$ & Survey Identification Number & & F & T \\
\hline $\mathbf{2}$ & No. of months since migrated & & & \\
\hline & \multicolumn{1}{|c|}{ M } & & \\
\hline $\mathbf{3}$ & No. of family members & & & \\
\hline $\mathbf{4}$ & Age & & & \\
\hline $\mathbf{5}$ & Never attended school & & & \\
\hline $\mathbf{6}$ & Primary school (up to class 7) & & & \\
\hline
\end{tabular}




\begin{tabular}{|c|c|c|c|c|}
\hline 7 & Secondary school (up to class 12 ) & & & \\
\hline 8 & Graduate & & & \\
\hline 9 & Income $1 \&$ SOI 1 (source of income) & Rs & & $\mathrm{M} / \mathrm{F}$ \\
\hline 11 & Income $2 \&$ SOI 2 & & & $\mathrm{M} / \mathrm{F}$ \\
\hline 12 & Income $3 \&$ SOI 3 & & & $\mathrm{M} / \mathrm{F}$ \\
\hline 13 & Total Income & & & \\
\hline 14 & Total Savings & \multicolumn{3}{|l|}{ Rs } \\
\hline 15 & Source of drinking water & \\
\hline 16 & Distance of water source from home & \multicolumn{3}{|r|}{$\mathrm{km}$} \\
\hline 17 & Where is the toilet that you use? & Inside home & $\begin{array}{l}\text { Outside } \\
\text { home }\end{array}$ & Open defecation \\
\hline 18 & Distance of toilet from home & \multicolumn{3}{|r|}{$\mathrm{km}$} \\
\hline 19 & Do you own this house? & Yes & Tenant & \\
\hline \multirow{2}{*}{20} & \multirow{2}{*}{ What type of tenancy agreement do you have? } & & & \\
\hline & & Written & Verbal & None \\
\hline 21 & Total rent & \multicolumn{3}{|r|}{ per $m$} \\
\hline 22 & By how much was the rent increased last year & \multicolumn{3}{|l|}{ Rs. } \\
\hline \multirow{7}{*}{23} & \multirow{7}{*}{ What is your expenditure on the following items } & Food & & \\
\hline & & Housing & & \\
\hline & & Education & & \\
\hline & & Transportation & & \\
\hline & & Health & & \\
\hline & & Telephone & & \\
\hline & & \multicolumn{3}{|l|}{ Remittances } \\
\hline 24 & Has anyone made improvements in this community? & & & \\
\hline 25 & \multicolumn{4}{|l|}{ What was the improvement? } \\
\hline 26 & \multicolumn{4}{|l|}{$\begin{array}{l}\text { What should be changed in the community under } \\
\text { current circumstances? }\end{array}$} \\
\hline \multirow{2}{*}{27} & \multirow{2}{*}{$\begin{array}{l}\text { Do you know of any Govt. schemes to improve living } \\
\text { conditions? }\end{array}$} & & & \\
\hline & & Yes & No & Name (if yes) \\
\hline 28 & What was your primary reason of migration? & & & \\
\hline 29 & What is the reason of staying back now? & & & \\
\hline
\end{tabular}




\begin{tabular}{|c|c|c|c|c|}
\hline 30 & $\begin{array}{l}\text { Do you want to go back to your hometown or some } \\
\text { other place after your current location? }\end{array}$ & & & \\
\hline 31 & How do you travel from home to your work place? & & & \\
\hline 32 & Is there any other transport that you use frequently? & & & \\
\hline & & & & \\
\hline & & & & \\
\hline & & & & \\
\hline & Page 2 starts here & & & \\
\hline $\begin{array}{l}\text { Sl. } \\
\text { No. }\end{array}$ & Questions & \multicolumn{2}{|c|}{$\begin{array}{l}\text { Write your responses } \\
\text { here }\end{array}$} & \\
\hline & Mark YES / NO to the following & Yes & No & \\
\hline 33 & Do you have a - & & & \\
\hline $\mathbf{a}$ & Ration card & & & \\
\hline $\mathbf{b}$ & Voter ID card & & & \\
\hline $\mathbf{c}$ & PAN card & & & \\
\hline d & Aadhar card & & & $\begin{array}{l}\text { Average hours } \\
\text { (if NO) }\end{array}$ \\
\hline $\mathbf{e}$ & Continuous supply of electricity at home & & & \\
\hline $\mathbf{f}$ & Continuous supply of water at home & & & \\
\hline $\mathbf{g}$ & Continuous supply of gas at home & & & \\
\hline $\mathbf{h}$ & Functional drain outside your home & & & \\
\hline $\mathbf{i}$ & Loan taken by you / any other family member & & & \\
\hline$\overline{\mathbf{j}}$ & Does your home flood during heavy rain? & & & \\
\hline $\mathbf{k}$ & Does the community's road flood during rain? & & & \\
\hline 1 & Has your home rent increased in last 1 year? & & & \\
\hline $\mathbf{m}$ & $\begin{array}{l}\text { Has any improvements been made in your community } \\
\text { in the last } 5 \text { years? }\end{array}$ & & & \\
\hline
\end{tabular}


APPENDIX C: DLF AND URBAN VILLAGE LOCATIONS

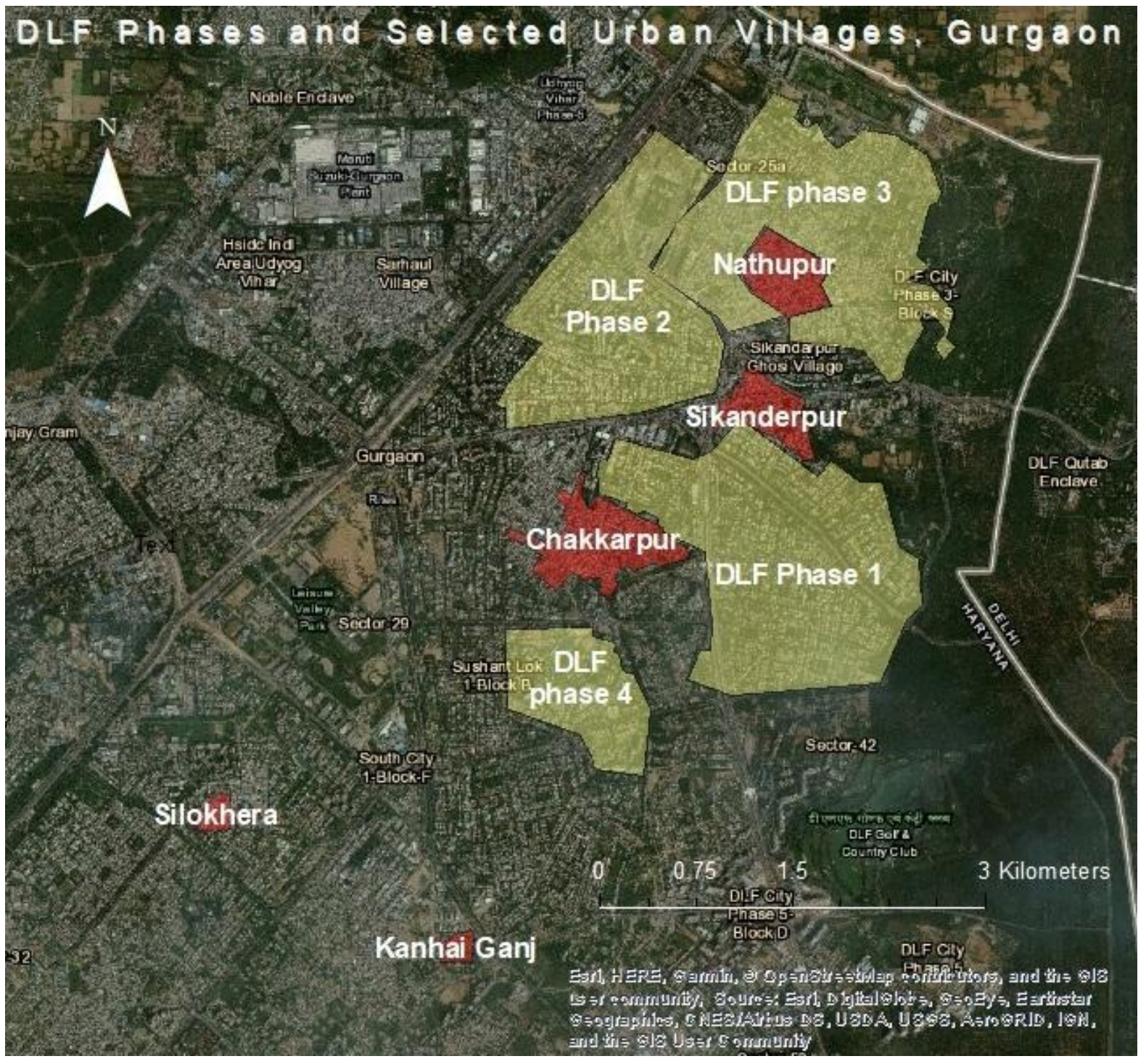




\section{REFERENCES}

Abbas, R. (2016). Internal migration and citizenship in India. Journal of Ethnic and Migration Studies, 42(1), 150-168.

Agamben, G. (2005). State of Exception. Chicago: University of Chicago Press.

Agnew, J. (2011). Space and Place. in Agnew, J. and Livingstone, D. eds. Handbook of Geographical Knowledge. London: Sage.

Anand, D. (Apr 2012). Gurgaon will drown in its own filth. Hindustan Times. retrieved from: https://www.hindustantimes.com/delhi-news/gurgaonwill-drown-in-own-filth/story-mEOaC9KZaGhW8AmmpdiHsM.html

Anand, N. (2017). The Hydraulic City: Water and the Infrastructure of Citizenship in Mumbai. Durham: Duke University Press.

Anderson, B. (1992). Imagined Communities: Reflections on the Origin and Spread of Nationalism. Verso.

Appadurai, A. (1996). Modernity at Large: Cultural Dimensions of Globalization. Minneapolis: University of Minnesota Press.

Appadurai, A. (2002). Deep Democracy: Urban Governmentality and the Horizon of Politics. Public Culture, 14(1), 21- 47.

Austin, J. (1961). Performative Utterances. Philosophical Papers. Oxford: Oxford University Press.

Basso, K.H. (1996). Wisdom sits in places: Notes on a Western Apache landscape. Santa Fe, New Mexico: School of American Research Press.

Baviskar, A. (2003). Between Violence and Desire: Space, Power and Identity in the Making of Metropolitan Delhi. Social Science Journal, 175, 89-98.

Baviskar, A. (1998). Towards a Sociology of Delhi: Report on a Seminar. Economic and Political Weekly, 33(49).

Baud, I., Sridharan, N., \& Pfeffer, K. (2008). Mapping Urban Poverty for Local Governance in an Indian Mega-City: The Case of Delhi. Urban Studies, 45(7), 1385-1412.

Bayat, A. (1997). Un-civil society: the politics of the 'informal people'. Third World Quarterly, 18 (1), 53-72. 
Benhabib, S. (1995). Cultural Complexity, Moral interdependence and the Global Dialogical Community. in eds. Nussbaum, M. and Glover, J., Women, culture, and development: a study of human capabilities. Oxford: Oxford University.

Benhabib, S. (1999). Citizens, Residents, and Aliens in a Changing World: Political Membership in the Global Era. Social Research, 66 (3), 709-744.

Benjamin, S. (2008). Occupancy Urbanism: Radicalizing Policy and Economics beyond Policy and Projects. International Journal of Urban and Regional Research, 32(3), 719-729.

Bhabha, H. K. (1994). The location of culture. London: Routledge.

Bhavnani, R.R., \& Lee, A. (2018). Local Embeddedness and Bureaucratic Performance: Evidence from India. The Journal of Politics, 80(1), 71-87.

Bhowmick, S. (Dec 28, 2013). Gurgaon most prosperous city in India. The Economic Times. Retrieved from: https://economictimes.indiatimes.com/gurgaon-mostprosperous-city-in-india/articleshow/28030074.cms

Björkman, L. (2015). Pipe politics, contested waters: embedded infrastructures of millennial Mumbai. Durham: Duke University Press.

Bonaiuto, M., Breakwell, G. M., \& Cano, I. (1996). Identity processes and environmental threat: The effects of nationalism and local identity upon perception of beach pollution. Journal of Community \& Applied Social Psychology, 6(3), 157-175.

Bowlby, J. (1970). Self-reliance and Some Conditions that Promote it. Lecture presented at Tavistock, Clinic, UK.

Brayne, F.L. (1929). The remaking of Village India. Oxford: Oxford University Press.

Caldeira, T. (2000). City of Walls: Crime, Segregation, and Citizenship in Sao Paulo. Berkeley: University of California Press.

Census of India. (2001). Data Highlights: Migration Tables.

Census of India. (2011). Rural Urban Distribution of Population (Provisional Population Totals).

Chacko, E. (2009). Identity and Representations of Gated Communities in Bangalore, India. Open House International, 34 (3), 57. 
Chakrabarty, D. (1991). Open space/public place: Garbage, modernity and India. Journal of South Asian Studies, 14(1), 15-31.

Chakrabarty, D. (1992). Of Garbage, Modernity and the Citizen's Gaze. Economic and Political Weekly, 27(10/11), 541-547.

Chandra, N.K. (2002). The Peasant Question from Marx to Lenin: The Russian Experience. Economic and Political Weekly, 37(20), 1927-1938.

Chatterjee, P. (2004). The Politics of the Governed: Reflections on Popular Politics in Most of the World. New York: Columbia University Press.

Chatterjee, P. (1993). The Nation and Its Fragments: Colonial and Postcolonial Histories. Princeton: Princeton University Press.

Chattopadhyay, S. (2012). Unlearning the City: Infrastructure in a New Optical Field. Minneapolis: University of Minnesota Press.

Clavel, P. (1986). The Progressive City: Planning and Participation 1969-1984. New Brunswick: Rutgers University Press.

Clayton, S. (2003). Environmental identity: conceptual and operational definition. in Clayton, S. and Opotow, S. eds., Identity and the natural environment: The psychological significance of nature. Cambridge, MA: MIT Press.

Cohn, B. (1987). The Census, Social Structure, and Objectification. in An Anthropologist among the Historians and Other Essays. 224-254.

Cowen, T. (2018). The urban village, agrarian transformation, and rentier capitalism in Gurgaon, India. Antipode, 50(5), 1244-1266.

Cowen, T. (2015). Fragmented Citizenships in Gurgaon. Economic and Political Weekly, 50(26-27), 63-73.

Cresswell, T. (2004). Place: A Short Introduction. Oxford: Blackwell Publishing.

Cronon, W. (1992). A place for stories: Nature, history, and narrative. The Journal of American History, 78(4), 1347-1376.

Crosthwaite, H.J. (1929). Report of the Town Improvements Trusts Committee. Allahabad.

Davidoff, P. (1996). Advocacy and Pluralism in Planning. in Campbell, S. and Fainstein, S. eds. Readings in Planning Theory. Oxford, UK and Malden, 
MA: Blackwell Publishing.

Davis, M. (2006). Planet of Slums. London: Verso.

Davis, M. (1990). City of Quartz: Excavating the Future in Los Angeles. London: Verso.

De Wit, J., \& Berner, E. (2009). Progressive Patronage? Municipalities, NGOs, CBOs and the Limits to Slum Dwellers' Empowerment. Development and Change, 40(5), 927-947.

Desmond, M. (2016). Evicted: poverty and profit in the American city. New York: Crown.

Deutsch, N. (2005). A second home. in Hirsch, B. J. ed., A place to call home: Afterschool programs for urban youth. Washington, DC: American Psychological Association.

Donthi, P. (Jan. 2014). The Road to Gurgaon: How the Brokers of Land and Power Built the Millennium City. The Caravan: A Journal of Politics and Culture.

Doron, A., \& Raja, I. (2015). The cultural politics of shit: class, gender and public space in India. Postcolonial Studies, 18(2),189-207.

Douglas, M. (2003). Purity and danger: an analysis of the concept of pollution and taboo. London: Routledge.

Dupont, V. D. N. (2011). The Dream of Delhi as a Global City. International Journal of Urban and Regional Research.

Evans, P.B. (1995). Embedded Autonomy: States and Industrial Transformation. Princeton, NJ: Princeton University Press.

Fainstein, S. (1996). New Directions in Planning Theory. in Campbell, S. and Fainstein, S. eds. Readings in Planning Theory. Oxford, UK and Malden, MA: Blackwell Publishing.

Falzon, M.A. (2004). Paragons of Lifestyle: Gated Communities and the Politics of Space in Bombay. City \& Society, 16(2), 145-167.

Feldman, R. M. (1990). Settlement identity: psychological bonds with home places in a mobile society. Environment and Behavior, 22, 183-229.

Fischel, W. (2001). The Homevoter Hypothesis: How Home Values Influence Local Government Taxation, School Finance, and Land-Use Policies. Cambridge, 
MA: Harvard University Press.

Flyvbjerg, B. (1996). Rationality and Power. in Campbell, S. and Fainstein, S. eds. Readings in Planning Theory. Oxford, UK and Malden, MA: Blackwell Publishing.

Forester, J. (2012). From Good Intentions to A Critical Pragmatism. The Oxford Handbook of Urban Planning. Oxford, UK: Oxford University Press.

Forester, J. (1999). The deliberative practitioner: Encouraging participatory planning processes. Cambridge, MA: MIT Press.

Fried, M. (1963). Grieving for a lost home. in Duhl, L.J. ed., The urban condition: People and policy in the metropolis. New York: Simon \& Schuster.

Friedmann, J. (2010). Place and Place-Making in Cities: A Global Perspective. Planning Theory \& Practice, 11(2), 149-165.

Friedmann, J. (2002). The Prospect of Cities. Minneapolis: University of Minnesota Press.

Friedmann, J. (1987). Planning in the Public Domain: From Knowledge to Action. Princeton: Princeton University Press.

Fritzen, F. (2009). Changing the World with Müsli. German Research, 31 (3), 10.

Frug, G. E. (1999). City Making: Building Communities without Building Walls. Princeton: Princeton University Press.

Fullilove, M. T. (1996). Root Shock: Psychiatric implications of displacement: contributions from the psychology of place. American Journal of Psychiatry, $153,1516-1523$.

Gandy, M. (2013). Marginalia: Aesthetics, Ecology, and Urban Wastelands. Annals of the Association of American Geographers, 103(6), 1301-1316.

Gans, H. (1982). Urban Villagers: Group and Class in the Life of Italian Americans. The Free Press.

Ghertner, A.D. (2013). Gentrifying the State: Governance, Participation, and the Rise of Middle-Class Power, in Delhi. Shatkin, G. ed. Contesting the Indian City: Global Visions and the Politics of the Local. John Wiley \& Sons.

Ghertner, A.D. (2011). Rule by Aesthetics: World-Class City Making in Delhi. In Roy, A., and Ong, A. eds., Worlding Cities: Asian Experiments and the Art of Being 
Global. Blackwell Publishing.

Ghertner, A. D. (2008). Analysis of New Legal Discourse Behind Delhi's Slum Demolitions. Economic and Political Weekly. 57-66.

Giddens, A. (1991). The consequences of modernity. Cambridge, U.K.: Polity Press.

Goldstein, S. (2016). Planning the Millennium City: The Politics of Place-making in Gurgaon, India. International Area Studies Review, 19(1), 12-27.

Graham, S., \& Marvin, S. (2001). Splintering Urbanism: Networked Infrastructures, Technological Mobilities and the Urban Condition. London: Routledge.

Gooptu, N. (1997). The Urban Poor and Militant Hinduism in Early TwentiethCentury Uttar Pradesh. Modern Asian Studies, 31(4), 879-918.

Goswami, M. (2004). Producing India: From Colonial Economy to National Space. Chicago: University of Chicago Press.

Gramsci, A. (1971). Selections from the Prison Notebooks. London: Lawrence and Wishart.

Gupta, A. (2012). Red Tape: Bureaucracy, Structural Violence, and Poverty in India. Durham: Duke University Press Books.

Gupta, A.C. (1979). Report of the Commission of Inquiry on Maruti Affairs. New Delhi: Central Government of India.

Gururani, S. (2013). Flexible Planning: The Making of India's Millennium City, Gurgaon. In Ecologies of Urbanism in India: Metropolitan Civility and Sustainability. Hong Kong: Hong Kong University Press.

Hall, P. (2002, 3rd edition). Cities of Tomorrow: An Intellectual History of Urban Planning and Design in the 20th Century. Wiley-Blackwell.

Harris J., \& Todaro, M. (1970). Migration, unemployment and development: A two sector analysis. American Economic Review, 60,126-142.

Harriss, J. (2005). Political Participation, Representation, and the Urban Poor: Findings from Research in Delhi. Economic and Political Weekly, 40,10411054.

Harvey, D. (2008). The Right to the City. The New Left Review. 23-40.

Harvey, D. (2007). A Brief History of Neoliberalism. Oxford: Oxford University Press. 
Harvey, D. (2005). Space as a Keyword. in Spaces of neoliberalization: towards a theory of uneven geographical development. Stuttgart: Franz Steiner Verlag.

Harvey, D. (2004). The 'New' Imperialism: Accumulation by Dispossession. Socialist Register, 40, 63-67.

Harvey, D. (1989). From managerialism to entrepreneurialism: the transformation in urban governance in late capitalism. Geografiska Annaler Series B, Human Geography, 71(1), 3-17.

Healey, P. (2014). Introduction. in Healey, P. ed. The Routledge Handbook of Planning Research Methods. Princeton: Princeton University Press.

Healey, P. (1996). The communicative turn in planning theory and its implications for spatial strategy formations. Environment and Planning B: Planning and Design, 23(2), 217-234.

Heller, P., Mukhopadhyay, P., \& Walton, M. (2016). Cabal City: Regime Theory and Indian Urbanization. The Watson Institute for International and Public Affairs at Brown University Working Paper No. 2016-32.

Hidalgo, M. C. C., \& Hernandez, B. (2001). Place attachment: conceptual and empirical questions. Journal of Environmental Psychology, 21(3), 273-281.

Hirt, S. A. (2012). Iron Curtains: Gates, Suburbs and Privatization of Space in the Post-socialist City. Wiley-Blackwell.

Holston, J. (2007). Insurgent Citizenship: Disjunctions of Democracy and Modernity in Brazil. Princeton, NJ: Princeton University Press.

Howard, E. (1902 [1946]). Garden Cities of To-Morrow. London: Faber and Faber.

Howitt, A.M. (1993). Regulating for Revenue: The Political Economy of Land use Exactions. Washington DC: The Brookings Institution Press.

Hull, M. (2012). Government of Paper: The Materiality of Bureaucracy in Urban Pakistan. University of California Press.

Hull, M. (2011). Communities of Place not Kind: American Technologies of Neighborhood in Post-Colonial Delhi. Comparative Studies in Sociology and History, 53(4), 757-790.

Jacobs, J. (1961). The death and life of great American cities. New York: Modern Library. 
Jackson, K. (1987). Crabgrass Frontier: The Suburbanization of the United States. Oxford: Oxford University Press.

Jain, S., \& Dandona, B. (2012). Haryana: A Cultural Heritage Guide. Aryan Books International.

Jeffery, J., Jeffery, P., \& Jeffery, C. (2011). Are Rich Rural Jats Middle class? in Baviskar, A., \& Ray, R eds., Elite and everyman: the cultural politics of the Indian middle classes. New Delhi: Routledge.

Jha, D. (2013). Gurgaon Collapsing? City stares at civic mess. Hindustan Times.

Kasarda, J. D., \& Janowitz, M. (1974). Community attachment in mass society. American Sociological Review, 39, 328-339.

Kaur, R. (2004). Across-Region Marriages: Poverty, Female Migration and the Sex Ratio. Economic and Political Weekly, 39 (25), 2595-2603.

Kedar, A., Amara, A., \& Yiftachel, O. (2018). Emptied lands: a legal geography of Bedouin rights in the Negev. Stanford, CA: Stanford University Press.

Korpela, K. M. (1989). Place-identity as a product of environmental self-regulation. Journal of Environmental Psychology, 9, 241-256.

Krishna, A. (2010). Continuity and change: the Indian Administrative Service 30 years ago and today. Commonwealth \& Comparative Politics, 48(4), 433-444.

Kudva, N. (2008). Teaching Planning, Constructing Theory. Planning Theory \& Practice, 9(3), 363-376.

Kudva, N. (2005). Strong States. Strong NGOs. in Ray, R. and Katzenstein, M.F. eds., Social Movements in India: Poverty, Power and Politics. Rowman \& Littlefield Publishers.

Kunstler, J. H. (1993). The geography of nowhere: the rise and decline of America's man-made landscape. New York: Simon \& Schuster.

Lalli, M. (1992). Urban-related identity: theory, measurement and empirical findings. Journal of Environmental Psychology, 12, 285-303.

Larios, B. and Voix, R. (2018). Introduction. Wayside Shrines in India: An Everyday Defiant Religiosity. South Asia Multidisciplinary Academic Journal. Association pour la recherche sur l'Asie du Sud. 
Legg, S. (2007). Spaces of Colonialism: Delhi's Urban Governmentalities. London: Wiley-Blackwell.

Le Goix, R. (2005). The Suburban Paradise or the Parceling of Cities: An Analysis of Discourses, Fears and Facts about the Sprawl of Gated Communities in Southern California. Housing Studies, 20 (2), 323-343.

Lemanski, C., \& Lama-Rewal, T. (2012). The 'missing middle': class and urban governance in Delhi's unauthorised colonies. Transactions of the Institute of British Geographers, 38, 91-105.

Lemanski, C., \& Oldfield, S. (2009). The Parallel Claims of Gated Communities and Land Invasions in a Southern City: Polarised State Responses. Environment and Planning A: Economy and Space, 41(3), 634-648.

Lockwood, D. (1989). The Black-coated Worker: a Study in Class Consciousness. ' Oxford, UK: Clarendon.

Logan, J. \& Molotch, H. (1987). Urban Fortunes: The Political Economy of Place. University of California Press.

Low, S. (2003). Behind the Gates: Life, Security, and the Pursuit of Happiness in Fortress America. Routledge.

Lung-Amam, W. S. (2017). Trespassers?: Asian Americans and the battle for suburbia. Oakland, CA: University of California Press.

Lynch, K. (1960). The Image of the City. Cambridge, MA: MIT Press.

Mager, C., \& Matthey, L. (2015). Tales of the City. Storytelling as a contemporary tool of urban planning and design. Journal of Urban Research.

Mandelbaum, S. (1991). Telling Stories. Journal of Planning Education and Research, 10, 209-214.

Mankekar, D.R., \& Mankekar, K. (1977). Decline and Fall of Indira Gandhi. New Delhi: Vision Books.

Manzo, L., \& Perkins, D. (2006). Finding Common Ground: The Importance of Place Attachment to Community Participation and Planning. Journal of Planning Literature, 20, 335-350.

Manzo, L. C. (2005). For better or worse: exploring multiple dimensions of place meaning. Journal of Environmental Psychology, 25(1), 67-86. 
Marris, P. (1987, 2nd edition). Meaning and Action. London: Routledge.

Marris, P. (1974) Loss and Change. London: Routledge.

Massey, D. (1999). Why Does Immigration Occur? A Theoretical Synthesis. in Hirschman, C., Kasinitz, P., and DeWind, J. eds. The Handbook of International Migration: The American Experience. New York: Russell Sage Foundation.

Massey, D. (1997). A Global Sense of Place. in Barnes, T. and Gregory, D. eds. Reading Human Geography. London: Arnold.

Mathur, K. (1996). Challenge of Good Governance India in the Post-Economic Reform Period. Fiscal Policy, Public Policy, and Governance. New Delhi: National Institute of Public Finance and Policy.

Matthey L. (2011). Urbanisme fictionnel: l'action urbaine à l'heure de la société du spectacle. Métropolitiques.

McGranahan, G., \& Satterthwaite, D. (2000). Environmental health or ecological sustainability: Reconciling the brown and green agendas in urban development. In Sustainable Cities in Developing Countries. London: Earthscan.

McMillan, D. W., \& Chavis, D. M. (1986). Sense of community: a definition and theory. Journal of Community Psychology, 14, 6-23.

Murphy, R. (2006). Internal Migration and Rural Livelihood Diversification. In ed. Clark, D.A. The Elgar Companion to Development Studies. Northampton, MA: Edward Elgar.

Narain, V., \& Vij, S. (2015). Land, Water \& Power: The demise of Common Property resources in peri-urban Gurgaon, India. Land Use Policy, 50, 59-66.

Narain, V. (2009). Growing City, Shrinking Hinterland: Land Acquisition, Transition and Conflict in Peri-Urban Gurgaon. Environment and Urbanization, 21(2).

Naik, M. (2015) Informal Rental Housing Typologies and Experiences of Low-income Migrant Renters in Gurgaon, India. Environment and Urbanization ASIA, 6 (2), $154-175$.

Nandy, A. (2001). An Ambiguous Journey to the City: the village and other odd ruins of the self in the Indian imagination. New Delhi: Oxford University Press. 
Narayana Kumar, K.P. (Aug. 2, 2012). Gurgaon: How not to Build a City. Forbes India. Retrieved from: http://forbesindia.com/article/real-issue/gurgaon-hownot-to-build-a-city/33444/1.

Nussbaum, M. (2011). Creating capabilities. Cambridge, MA: Harvard University Press.

Nussbaum, M. (2004). Hiding from Humanity: Disgust, Shame, and the Law. Princeton, NJ: Princeton University Press.

Nussbaum, M., \& Amartya, S. (1993). The quality of life. Oxford, UK: Clarendon.

Oldenburg, V. (April 15, 2016). City that Grew at Night: Renaming Gurgaon as Gurugram Indicates Rustic Imagination of Millennium City's Political Masters. Times of India. Retrieved from: http://blogs.timesofindia.indiatimes.com/toi-edit-page/city-that-grew-at-nightrenaming-as-gurugram-indicates-rustic-imagination-of-millennium-cityspolitical-masters/.

Oldenburg, V. (2018). Gurgaon: From Mythic Village to Millennium City. New Delhi: Harper Collins India.

Pellow, D., \& Lawrence-Zuniga, D. (2008). The Self-Consciousness of PlaceMaking. Anthropology News, 49(9), 4-5.

Perkins, D. D., \& Long, A. D. (2002). Neighborhood sense of community and social capital: a multi-level analysis. in Fisher, A., Sonn, C. and Bishop, B. eds., Psychological sense of community: Research, applications and implications. New York: Plenum Press.

Pierre, J. (2009). New Governance, New Democracy? QoG Working Paper Series.

Polanyi, K. (1944). The Great Transformation. Farrar \& Rinehart.

Portes, A. (1997). Immigration theory for a new century. International Migration Review.

Potter, D. 1996 [1986]. India's Political Administrators: From ICS to IAS. Delhi: Oxford University Press.

Prakash, G. (2002). The Colonial Genealogy of Society: Community and Political Modernity in India. in Joyce, P. ed., The Social in Question: New

Bearings in History and the Social Sciences. London: Routledge.

Pubby, V. (Feb 2018). Manesar Land Scam: Long Battle Awaits Bhupinder Singh 
Hooda as Shady Deals Return to Haunt former CM. First Post. Retrieved from: https://www.firstpost.com/india/manesar-land-scam-long-battle-awaitsbhupinder-singh-hooda-as-shady-deals-return-to-haunt-former-haryana-cm4334681.html

Raman, B. (2012). Document Raj: writing and scribes in early colonial South India. Chicago: University of Chicago Press.

Rajagopalan, S., \& Tabarrok, A. (2014). Lessons from Gurgaon, India's Private City. in Andersson, D.E. and Moroni, S. eds. Cities and Private Planning. Edward Elgar Publishing.

Rao, N. (2012). House but no Garden: Apartment Living in Bombay's Suburbs, 18981964. Minneapolis: University of Minnesota Press.

Rawat, R. S. (2011). Reconsidering untouchability: Chamars and Dalit history in North India. Bloomington: Indiana University Press.

Ray, R. (2003). The Precarious Middle Class: Gender, Risk, and Mobility in the New Indian Economy. in Bhavnani, K. K. ed., Feminist futures: Reimagining women, culture and development. London: Zed Books Ltd.

Relph, E. (1976). Place and placelessness. London: Pion, Ltd.

Rittel, H.W.J., \& Weber, M.M. (1973). Dilemmas in a General Theory of Planning. Policy Sciences, 4(2), 155-169.

Robinson, J. (2006). Ordinary cities: between modernity and development. London: Routledge.

Rodrik, D., \& Subramanian, A. (2004). From Hindu Growth to Productivity Surge: The Mystery of the Indian Growth Transition. NBER Working Paper Series.

Row, T. V. S. (1907). The Land acquisition act, 1894. (Act I of 1894): (with the cases-law thereon.). Madras, M. E. press.

Roy, A., \& Ong, A. eds. (2011). Introduction. Worlding cities: Asian experiments and the art of being global. Malden, MA: Wiley-Blackwell.

Roy, A. (2009). Why India Cannot Plan Its Cities: Informality, Insurgence, and the Idiom of Urbanization. Planning Theory, 8(1), 76-87.

Roy, S. (2007). Beyond Belief: India and the Politics of Postcolonial Nationalism. Durham: Duke University Press. 
Sadiq, K. (2008). Paper Citizens: How Illegal Immigrants Acquire Citizenship in Developing Countries. Oxford: Oxford University Press.

Sandercock, L. (2004). Towards a Planning Imagination for the 21st Century. Journal of the American Planning Association, 70(2), 133-141.

Sandercock L. (2003). Out of the closet: The importance of stories and storytelling in planning practice. Planning Theory \& Practice, 4(1), 11-28.

Sassen, S. (1988). The Mobility of Labor and Capital: A Study in International Investment and Labor Flow. Cambridge: Cambridge University Press.

Sassen, S. (1991). The Global City: New York, London, Tokyo. Princeton University Press.

Satterthwaite, D. (2004). The under-estimation of urban poverty in low and middleincome nations. Working Paper.

Scannell, L., \& Gifford, R. (2010). Defining Place Attachment: A Tripartite Organizational Framework. Journal of Environmental Psychology. 30, 1-10.

Schon, D. (1984). The Reflective Practitioner: How Professionals Think in Action. Basic Books.

Searle, L. G. (2016). Landscapes of accumulation: real estate and the neoliberal imagination in contemporary India. Chicago: The University of Chicago Press.

Shatkin, G. (2017). Cities for profit: the real estate turn in Asia's urban politics. Ithaca: Cornell University Press.

Shatkin, G. (2013). Contesting the Indian City: Global Visions and the Politics of the Local. International Journal of Urban and Regional Research, 38(1).

Shatkin, G. (2007). Global cities of the South: Emerging perspectives on growth and inequality. Cities, 24 (1), 1-16.

Sheppard, E. S., Porter, P. W., Faust, D. R., \& Nagar, R. (2009). A World of Difference: Encountering and Contesting Development. New York: Guilford Press.

Simmel, G. (1903). The metropolis and mental life.

Singh, K.P., Menon, R., \& Swamy, R. (2011). Whatever the Odds: The Incredible Story Behind DLF. New Delhi: Harper-Collins India. 
Siwach, V. (Mar 2018). In 51st posting as IAS, Ashok Khemka gears up for dangal in Haryana. Indian Express. Retrieved from: https://indianexpress.com/article/sports/sport-others/ias-officer-ashokkhemka-gears-up-for-a-new-dangal-5105150/

Smith, N. (1984). Uneven Development: Nature, Capital and the Production of Space. Oxford: Blackwell.

Sridharan, E. (2011). The Growth and Sectoral Composition of India's Middle Classes: Their Impact on the Politics of Economic Liberalization. in Baviskar, A ed. Elite and Everyman: The Cultural Politics of the Indian Middle Classes. Routledge India.

Srivastava, S. (2014). Entangled Urbanism: Slum, Gated Community, and Shopping Mall in Delhi and Gurgaon. Oxford: Oxford University Press.

Srivastava, S. (2012). National Identity, Kitchens, and Bedrooms: Gated Communities and New Narratives of Space in India. in Liechty, M., Freeman, C., and Heiman, R. eds., The Global Middle Classes: Theorizing through Ethnography. Santa Fe: School of Advanced Research Press.

Stark, O., \& Bloom, D. E. (1985). The New Economics of Labor Migration. American Economic Review Papers and Proceedings, 75(2), 173-178.

Stedman, R. (2003). Is it really just a social construction? The contribution of the physical environment to sense of place. Society and Natural Resources, 16, 671-685.

Stoker, G. (2006). Public Value Management: A New Narrative for Network Governance. The American Review of Public Administration, 36(41).

Stokols, D., \& Shumaker, S. A. (1981). People in places: a transactional view of settings. in Harvey, J. ed., Cognition, social behavior, and the environment. Hillsdale, NJ: Erlbaum.

Strydom, W., Puren, K., \& Drewes, E. (2018). Exploring theoretical trends in placemaking: towards new perspectives in spatial planning. Journal of Place Management and Development, 11(2), 165-180.

Sundaram, R. (2011). Pirate Modernity: Delhi's Media Urbanism. Routledge.

Surendran, C.P. (April 15, 2016). When Mythology Becomes History, Gurgaon becomes Gurugram. Daily O. Retrieved from:

http://www.dailyo.in/politics/gurugram-gurgaon-bjp-modi-hindutva-pandavasdronacharya-rss-khattar-mahabharata-draupadi-hindu- 
mythology/story/1/10098.html

Tarlo, E. (2001). Unsettling Memories: Narratives of the Emergency in Delhi. Berkeley: University of California Press.

Theodore, N., Peck, J., \& Brenner, N. (2011). Neoliberal Urbanism: Cities and the Rule of Markets. in Bridge, G. and Watson, S. eds. The New Blackwell Companion to the City. Sussex: Wiley-Blackwell.

Throgmorton, J. A. (2003). Planning as persuasive storytelling in the context of 'the network society'. Planning Theory, 2(2), 125-151.

Tuan, Y. (1974). Topophilia: A study of environmental perception, attitudes, and values. Englewood Cliffs, N.J: Prentice Hall.

Tumbe, C. (2016). Urbanization, demographic transition, and the growth of cities in India, 1870-2020. Working Paper Series: International Growth Centre.

Twigger-Ross, C. L., \& Uzzell, D. L. (1996). Place and identity processes. Journal of Environmental Psychology, 16, 205-220.

UNDP (United Nations Development Program). (2009). Overcoming Barriers: Human Mobility and Development, Human Development Report.

UNFPA (United Nations Population Fund). (2015). Migration.

Uzzell, D., Pol, E., \& Badenas, D. (2002). Place identification, social cohesion, an environmental sustainability. Environment and Behavior, 34, 26-53.

Vaishnav, M., \& Khosla, S. (2016). The Indian Administrative Service Meets Big Data. Carnegie Endowment for International Peace. Working Paper. Retrieved from: https://carnegieendowment.org/2016/09/01/indian-administrativeservice-meets-big-data-pub-64457

van Hulst, M. (2012). Storytelling, a model of and a model for planning. Planning Theory, 11(3), 299-318.

Vorkinn, M., \& Riese, H. (2001). Environmental concern in a local context: the significance of place attachment. Environment and Behavior, 33, 249-263.

Warner, M.E. (2011). Club Goods and Local Government. Journal of the American Planning Association, 77(2), 155-166.

Watson, V. (2009). Seeing from the South: refocusing urban planning on the globe's central urban issues. Urban Studies, 46(11), 2259-2275. 
Wohl, S. (2017). From form to process: Re-conceptualizing Lynch in light of complexity theory. Urban Design International, 22(4), 303-317.

Yiftachel, O. (1998). Planning and Social Control: Exploring the Dark Side. Journal of Planning Literature, 12 (2), 395-406.

Zhang, L. (2008). Private Homes Distinct Lifestyles: Performing a New Middle Class. in Zhang, L. and Ong, A. eds. Privatizing China, Socialism from Afar. Ithaca: Cornell University Press. 